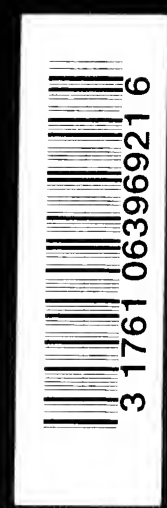




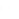

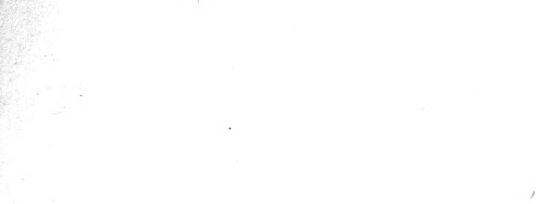

\section{.}

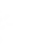




$$
\text { . }
$$ 
7 HIS volume is published by authority of the Executive Board of the Graduate School of the University of Michigan. A list of other volumes thus far published or arranged for is given at the end of this volume. 
THE LIFE AND WORK OF

OF

GEORGE SYLVESTER MORRIS 


\section{THE MACMILLAN COMPANY \\ NEW YORK BOSTON CHICAGO \\ ATLANTA SAN FRANCISCO \\ MACMILLAN \& CO., Limited \\ LONDON BOMBAY CALCUTTA \\ MELBOURNE}

THE MACMILlan CO. OF CANADA, Ltd.

TORONTO 
Geo. Morris. 


\title{
THE LIFE AND WORK \\ OF \\ GEORGE SYLVESTER MORRIS
}

\author{
A CHAP'TER IN THE HISTORY OF AMERICAN \\ THOUGHT IN THE NINETEENTH CENTURY
}

BY

R. M. WENLEY

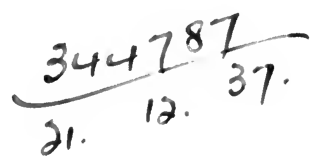

Nebo mork

\section{THE MACMILLAN COMPANY}

London: Macmillan \& Company, Limited 1917

All rights reserved 
Copyright, 1917

By R. M. WENLEY

Printed from type, June, 1917 


\section{PREFACE}

Whatever be the case with the older foundations of New England and the East, the State Universities, now entering upon their third generation, have not yet accustomed themselves to pietas. Nay, the tendency towards it is weaker now, perhaps, than it was twentyfive years ago. Expansion and transformation have raised so many practical problems of urgent concern that even significant persons come and go like players in a booth, as Plutarch said of the hapless puppets who 'ruled' after Nero. The worth and work of men of mark are taken for granted. Michigan, particularly when her age, position and humane spirit are considered, has been strangely neglectful of her greatest servantsand of herself. A life of Tappan, her real founder, remains to be written. It is to be deplored that biographies of Frieze, of Watson, of Olney, of Hinsdale, to name no others, fail us, For, as Dr. Angell says, they, more than any one except Tappan, have built their lives into the University.* Where they sowed, we reap; we have literally entered into their labors. The history of the University - the veritable tale of her inner waysexists only for the day of small things. My first predecessor, Andrew Ten Brook, $\uparrow$ has furnished an account till the close of the Haven administration; $\ddagger$ and Haven

* Cf. The Reminiscences of James Burrill Angell, pp. 228 f.

$\dagger$ Born 1814; died 1899; Professor of Moral and Intellectual Philosophy, 1844-51; University Librarian, 1864-77.

¥Cf. American State Universities. Their Origin and Progress: a History of Congressional Land-Grants; a Particular Account of the Rise and Development of the University of Michigan, and Hints toward the Future of the American University System (Cincinnati, 1875). 
resigned in 1869! Although this happens to be a classical contribution, so little are we interested in our past that it has lacked due appreciation, stands dusty on our shelves, and Ten Brook is an empty name to the present Michigan man.*

In these circumstances, I have deemed it a privilege to be asked to attempt an interpretation of the life of George Sylvester Morris, whose connection with the University began just at the close of the period covered by Ten Brook's history, and whose labours did so much to throw lustre, not only upon the Philosophical Department, but also upon the College of Literature, Science and the Arts. Yet, for the reasons indicated, I at once found myself amidst a sea of troubles. The facts indispensable to an adequate biography had been permitted to lapse. To reassemble them, twenty-five years after Morris had entered into rest, I have been compelled to take endless trouble. These difficulties would have been mitigated had his Michigan contemporaries discerned his strategic position in the development of American culture. Moreover, at some points I have been baffled, despite all pains; for those who could have set the situation in proper perspective from personal knowledgehad passed away. Nevertheless, on the whole, thanks

* "The present Michigan man" who, perhaps, needs to have his memory jogged, may learn from figures, as from nothing else, how completely Ten Brook's book confines itself to "the day of small things." In 1869 the number of students was 1112 , of the Faculty, 31 ; the total expenditure, $\$ 74,500$-little more than the Library alone costs now. Writing in 1888, Morris said to a Swiss friend; "Our University is very prosperous. The attendance here is larger than at any other American University. We have over 1800 students." At this time there were 1882 students and 100 members of Faculty; the expenditure was $\$ 225,000$. The latest complete figures (1915-16) are--7214 students; 527 officers of instruction; income, $\$ 2,202,860$. 
to the coöperation of Mrs. and Miss Morris, I have met with more success than seemed possible at the first blush. But, I would warn others, that efforts should be made to preserve even details connected with the activities of prominent or influential men. These may very well appear trivial at the moment. Yet, just such trivial things serve to offer important clues after years have elapsed, for, as is obvious, they form the links of every life. How serious the difficulties, due to the lapse of evidence, have been, may be gathered from those facts. I began my researches in the summer of 1910. I was able to begin to write only in October, 1913, and to finish the first draft of the Introduction and Chapters I.-VIII. in January, 1915. Delays caused by obscure episodes were constant. Since the first draft was finished, I have sought to elucidate incidents which remained dark, despite every care. For example, only late in 1915 was I enabled to identify Mr. Larrowe unequivocally. Hundreds of letters were necessary, and many, addressed at a venture to those who had known Morris, either failed to reach their destination or had been sent to dead men.

Although Morris died in his prime and, thanks to an unusual combination of circumstances, just as he was beginning to achieve a final standpoint, his rare personality stamped itself upon this University. Moreover, thanks to his complete equipment in scholarship, he punctuated an epoch in philosophical education at our institutions of the higher learning. What is most significant, perhaps, his intellectual history, despite its sudden end, epitomises that of many minds in his day, because it embodies a representative human experience peculiar to the second half of the nineteenth century, 
particularly in the English-speaking world. At grave disadvantages in certain respects, he yet takes his place with James Hutchison Stirling, John Caird, Edward Caird, Thomas Hill Green, William Wallace, Robert Adamson, William T. Harris, and C. C. Everett, the idealists of the first generation, who deflected the thought characteristic of Great Britain and the United States, and brought it into the main stream of post-Kantian philosophy. He attained this difficult fellowship late in his career, and only after numerous mental trials, which beset him through one half of his awakened years. This spiritual drama it is that lends present, possibly permanent, interest to the man. At all events, I do not know another figure who typifies so fully the struggles through which we have been enabled to enter upon a larger outlook.

I have tried to acknowledge my many obligations in the text. But I should be churlish indeed were I not to make special mention of Mrs. Cone, Morris's favorite niece, who has enabled me to reconstruct the earlier life; and of Dr. James B. Angell, with whom I spent many hours, made precious by his presence, in conversation about the University of Michigan as it was during the eighteen years when his Presidency ran parallel with Morris's Professorships. His intimate knowledge of the influential men, and of the academic problems, suffused as it was by the wisdom of unique experience since, controlled my interpretation of the evidence at every point. He has the credit for such new light as Morris's career undoubtedly casts upon the internal history of the University between 1870 and 1890 .

R. M. Wenley. 


\section{CONTENTS}

PAGE

Writings of G. S. Morris. . . . . . . . . . . xi

Introductory: The Morris Line............. 1

Chapter I. The New England Home....... 11

Chapter II. School and College (1854-61).... 34

Chapter III. Early Manhood. Royalton. The

Civil War.' Dartmouth College Once More $(1861-64) \ldots \ldots .62$

Chapter IV. Union Theological Seminary. Europe. Transition (1864-70) 88

Chapter V. Michigan: The First Period. The Johns Hopkins Episode (1870-81) 122

Chapter VI. Withdrawal from Johns Hopkins. Michigan: The Second Period (1881-89) . . . . . . . . 144

Chapter VII. Intellectual History. Origins and Transition............. 177

Chapter VIII. Intellectual History. The Final Stage.............. 239

Chapter IX. 'The Man and The Teacher. . . . 296 INDEx . . . . . . . 327 


\section{WRITINGS OF G. S. MORRIS}

(During his service at the front in the Civil War, Morris acted as correspondent of one of the Vermont newspapers, to which he contributed articles. Despite diligent search, it has been impossible to recover these writings.)

\section{7}

Hodgson on Time and Space. The American Presbyterian and Theological Review (New Series), Vol. V., pp. 217-38.

\section{9}

Translation of "The Theosophy of Franz Baader," by Dr. Julius Hamberger. The American Presbyterian Review (New Series), Vol. I., pp. 171-85.

\section{1}

Translation of "A History of Philosophy from Thales to the Present Time," by Dr. Friedrich Ueberweg. Vol. I., "History of the Ancient and Mediaeval Philosophy." New York; Charles Scribner and Company.

\section{2}

Translation of Ueberweg's "History," Vol. I. London; Hodder and Stoughton.

Admission to the University. The Preparation in French. The Michigan Teacher, Vol. VII., pp. 267-71.

\section{3}

Translation of "A History of Philosophy from Thales to the Present Time," by Dr. Friedrich Ueberweg. Vol. II., "History of Modern Philosophy." New York; Charles Scribner and Company.

Translation of Ueberweg's "History," Vol. II. London; Hodder and Stoughton.

A Circular to Teachers of French in the Preparatory Schools (Ann Arbor). 
Notes on "A New Treatise on French Verbs," by Alfred Hennequin. The Michigan Teacher, Vol. IX., pp. 224-5, 263-4.

Vera on Trendelenburg. The Journal of Speculative Philosophy, Vol. VIII., pp. 92-4.

Friedrich Adolf Trendelenburg. The New Englander, Vol. XXXIII., pp. 287-336.

\section{5}

Translation of Ueberweg's "History." 2 vols. Second Edition. London: Hodder and Stoughton.

The Final Cause as Principle of Cognition in Nature. 8vo, pp. 31. London; Robert Hardwicke. Reprinted from the Journal of the Transactions of the Victoria Institute, or Philosophical Society of Great Britain. (This paper was read, on behalf of Morris, by Prebendary Rowe, at an Ordinary Meeting of the Institute, held on 18th May, 1874. It appears in Vol. IX. of the Journal, pp. 176-204).

\section{6}

Translation of Ueberweg's "History." 2 vols. New Edition. New York; Charles Scribner and Company.

The Theory of Unconscious Intelligence as Opposed to Theism; being a Paper Read before the Victoria Institute, or Philosophical Society of Great Britain. 8vo, pp. 47, London: Hardwicke and Bogue. (This paper was read. on behalf of Morris, by the Rev. T. M. Gorman, at an Ordinary Meeting of the Institute, held on 19th June, 1876. It appears in Vol. XI. of the Journal, pp. 247-91.)

The Philosophy of Art. The Journal of Speculative Philosophy, Vol. X., pp. 1-16.

Review of "Philosophy of Trinitarian Doctrine: a Contribution to Theological Progress and Reform," by Rev. A. G. Pease. Ibid., pp. 111-12.

The Immortality of the Human Soul. A University Address. The Bibliotheca Sacra (Andover), Vol. XXXIII., pp. 695-715. 
Spinoza-a Summary Account of His Life and Teaching. The Journal of Speculative Philosophy, Vol. XI., pp. 278-99.

1878

The Johns Hopkins University. The Michigan Chronicle, Vol. IX., p 180.

1879

Translation of Ueberweg's "History." Vol. I. Third Edition. London: Hodder and Stoughton.

Philosophy at Johns Hopkins University. The Journal of Speculative Philosophy, Vol. XIII., pp. 398-9.

\section{0}

Translation of Ueberweg's "History." Vol. II. Third Edition. London: Hodder and Stoughton.

British Thought and Thinkers: Introductory Studies, Critical, Biographical and Philosophical. 12mo, pp. 388. Chicago: S. C. Griggs and Company.

A Report on Wundt's "Logik" (Bd. I. "Erkenntnisslehre") [Abstract.] Johns Hopkins University Circulars, No. 7, p. 84 .

Leslie Stephen on Causation [printed by title only]. Ibid., p. 85 .

\section{1}

Kant's Transcendental Deduction of the Categories. Read at the Concord School of Philosophy. The Journal of Speculative Philosophy, Vol. XV., pp. 253-74.

German Philosophy for English Readers. Ibid., pp. 323-24.

1882

Kant's Critique of Pure Reason. A Critical Exposition. 12mo, pp. xvi+272. Chicago: S. C. Griggs and Company. English Deism and the Philosophy of Religion [Abstract]. Johns Hopkins University Circular, No. 13, pp. 177-78. Philosophy and its Specific Problems. The Princeton Review (New Series), Vol. IX., pp. 208-52. 
Philosophy at Johns Hopkins University [Programme]. The Journal of Speculative Philosophy, Vol. XVI., pp. 45-51.

Add to Virtue Knowledge [Abstract]. The Monthly Bulletin (Ann Arbor), Vol. III., No. 8, pp. 1-2.

\section{3}

The Fundamental Conceptions of University and Philosophy [Abstract]. Johns Hopkins University Circulars, Vol. II., No. 21, p. 54.

Syllabus of Eight Lectures on Philosophy and Christianity. 8vo, pp. 10. (Baltimore).

The same. The Journal of Speculative Philosophy, Vol. XVII., pp. 215-20.

Henry James [printed by title only]. Johns Hopkins University Circulars, Vol. II., No. 21, p 64.

The Philosophical Conception of Life [Abstract]. Ibid., Vol. III., No. 27, pp. 12-13.

Agnosticism. Supplement [American] to Encyclopæedia Britannica, Vol. I.

Causation. Ibid.

Dr. Cocker's Philosophical Attitude. The Michigan Argonaut, Vol. I., pp. 245-47.

Philosophy and Christianity: a Series of Lectures Delivered in New York, in 1883, on the Ely Foundation of the Union Theological Seminary. 12mo, pp. xiv +315 . New York: Robert Carter and Brothers.

\section{4}

Review of Dr. W. T. Harris's "Philosophy in Outline" [printed by title only]. Johns Hopkins University Circulars, Vol. III., No. 29, p. 70.

Translation of Ueberweg's "History," Vol. I. Fourth Edition. London: Hodder and Stoughton.

Conception. Supplement [American] to Encyclopaedia Britannica, Vol. II.

Conceptualism. Ibid.

Consciousness. Ibid. 
1885

Translation of Ueberweg's "History," Vol. II. Fourth Edition. London: Hodder and Stoughton.

Reports on Fred Kapp's "Grundriss einer Philosophie der Technik" and on Du Prel's "Philosophie der Mystik" [printed by title only]. Johns Hopkins University Circulars, Vol. IV, No. 35, p. 28.

The Method of Philosophy [printed by title only]. Ibid., No. 38 , p. 66 .

1886

The Philosophy of the State and of History. Pedagogical Library (edited by G. Stanley Hall). Vol. I. Methods of Teaching History. Second Edition, pp. 149-66. Boston: D. C. Heath and Company.

Philosophy at Michigan University. The Journal of Speculative Philosophy, Vol. XX., pp. 331-32.

University Education. University of Michigan Philosophical Papers. First Series, No. 1, 8vo, pp. 40. Ann Arbor: Andrews and Witherby.

1887

Hegel's Philosophy of the State and of History. An Exposition. 12mo, pp. xiii +306. Chicago: S. C. Griggs and Company.

1888

Review of "A Brief History of Greek Philosophy," by B. C. Burt. The Michigan Argonaut, Vol. VII., pp. 67-8.

1900

Translation of Ueberweg's "History." 2 vols. Fifth Edition. London: Hodder and Stoughton.

Note.-By an unfortunate oversight, rare indeed in this publication, the works of George Sylvester Morris possessed by the British Museum Library are printed under the name of George Sculthorpe Morris in the "British Museum Catalogue." This author, who appears to be unknown otherwise, wrote pamphlets upon the transportation of convicts to Australia. The Museum authorities have been apprised of the error, and will see that it is corrected. 


\section{INTRODUCTORY}

\section{The Morris Line}

Despite recent inquiry and speculation, much remains to do ere man can penetrate the secrets of his intellectual and moral nature. If physiological 'heredity' chastise our knowledge with whips, social 'heredity' chastises it with scorpions. Nevertheless, when the group-influences, inseparable from intellectual and moral achievement, come in question, it seems plain that every notable life "is built up of an enormous number of. subordinate lives,"* but of lives like-minded, in the sense that they create or maintain a normal standard, itself very complex, which the exceptional career serves to epitomize. However these obscure problems stand today, few will deny that the culture-system peculiar to the New England colonies was a type-a type dominated by a saving sense of order and thrift on earth, by a no less saving sense of grave responsibility to the fearful issues that sprang from primitive notions of a covenant relation between God and man. For, while it is true that the first English immigrants entertained "the visible hope of a great and rich trade" they were possessed even more by pictorial beliefs concerning "the things unseen and eternal." In a word, such were the conditions of existence in old East Anglia and in the new Atlantic colonies alike, that without transitive spiritual supports survival would have been impossible. Pilgrim and Puritan sought a far country where they might build convictions into daily duties, unhampered by Roman

* Hereditary Genius, Francis Galton, p. 349. (1st ed.). 
formalism, untempted by the gay effronteries of Renaissance humanism. The challenge of a refractory land, and of crafty foes, set the world in their hearts, developing further the practical steadiness so conspicuous in the English. But they had suffered heroically for an idea, not because it was an idea, but because it endowed them with privileges, and they were bound to construct a civil society wherein they might rise to the level of their high mission as the chosen people of Jehovah. Hence, two inexpugnable forces pulled the immigrants two ways, rendering their culture much less simple than is often supposed and, at the same time, assuring persistent vitality. Thus, economic diligence, of the earth earthy, yet the basis of every civilization, became quite worthy, and found local habitation in the industrial family; while, despite these cares of this world, the fear of the Lord remained at once the beginning and the completion of wisdom.

Nay, more, the New England conscience was compounded of two spiritual strains which, taken together, afford the clue to several apparent contradictions.

"The Puritan differs from the Pilgrim as the Hebrew prophet from Saint John. Abraham, ready to sacrifice Isaac at the command of God; Jeremiah, uttering his terrible prophecy of the downfall of Judæa; Brutus, condemning his son to death; Brutus, slaying his friend for the liberty of Rome; Aristides, going into exile, are his spiritual progenitors, as Stonewall Jackson was of his spiritual kindred. You will find him wherever men are sacrificing life or the delights of life on the altar of Duty. But the Pilgrim is of a gentler and a lovelier nature. He, too, if Duty or Honour call, is ready for the sacrifice. But his weapon is love and not hate. His spirit is the spirit of John, the beloved Disciple, the spirit of Grace, Mercy and Peace. His memory is as sweet and fra- 
grant as the perfume of the little flower which gave its name to the ship which brought him over."**

In short, the Pilgrim was a vessel of divine grace, the Puritan a rebel against the corruptions which, as he thought, had overtaken even the holy things of 'merrie' England, whose crude, indecent and brutal roysterings he abhorred. For the one, the kingdom of heaven was already within you-man is man, but vaster; for the other, a legal system was imperative, in order that established, applicable rule might keep the righteous people on the narrow path. Accordingly, the Puritan founded a new state; the Pilgrim, on the contrary, nourished a mood within this state-a mood destined to come to its own eventually, because it preserved an open way back to relations with an ampler discernment of the holiness of beauty and the righteousness of every effort after truth. Bunyan himself forecast one aspect of this temper.

"Christiana, if need was, could play upon the viol, and her daughter Mercy upon the Lute; so, since they were so merry disposed, she played them a Lesson, and Ready-to-halt would dance. So he took Despondency's Daughter named Much-afraid by the hand, and to dancing they went in the Road. True he could not dance without one Crutch in his hand, but, I promise you, he footed it well. Also the Girl was to be commended, for she answered the music handsomely."

It is obvious that this plain, prudent living, and high, if theological, thinking, found embodiment, preserved and confirmed through eight generations, in the Morris line. Temporary divergencies, such as there were, would seem to have been neutralized, if not eliminated, so

* Speech of the late Senator Hoar, of Massachusetts, before the New England Society of Charleston, S. C., 22d December, 1898. 
that the New England type persisted, throwing straight from father to son. In the first known ancester, Thomas Morris, the Nazing associate of the saintly John Eliot, the Pilgrim temperament and outlook held gentle, persuasive sway. Seven generations later, in the nineteenth century, George Sylvester Morris was assuredly a reversion to the Pilgrim amenity of sentiment; he could have declared as Eliot did, towards the close of his long, beneficent career:

"My understanding leaves me, my memory fails me, my utterance fails me; but, I thank God, my charity holds out still."*

After Thomas Morris, the inevitable cares of this world, and the equally inevitable masterfulness of the Puritan bit deep. It is a plain tale. Godliness prospers, well yoked with contentment following upon hard-won competence, till, in the person of Sylvester Morris, we have the express image of the Philistine-so his granddaughter terms him-in local and national politics, a man absorbed in the ideal and, recking neither the means nor their pressure upon the weaker brethren. Nevertheless, even his touch of genius could not disinherit his folk of their rights in the Pilgrim spirit. Pilgrim tendencies were betrayed by his father, if with Puritan exterior. They found expression in his mother, and worked like a leaven in the family where he found a wife. Finally, as if roused by long denial, they dominated the person of his distinguished son, in whom beauty of character touched intellectual power to fine issues, and purity of soul found fit utterance in "the speech of angels," as Carlyle called music.

Two hundred and eleven years intervene between

* Cf. Ten New England Leaders, Williston Walker, p. 171. 
the marriage of Thomas Morris at Nazing, Essex, England, and the birth of George Sylvester Morris, at Norwich, Vermont. And, in these days of rapid change, there can be few examples of an English ancestry so pure, one so completely moulding, and moulded by, the special conditions peculiar to the inwardness of the meditative passion that throbbed in the founders of the New England theocracy. As the admirable book, wrought with pious care by Mr. Tyler Seymour Morris,* was issued in a limited edition many years ago, it is not only apposite, but worth while, to notice the forebears of George Sylvester Morris in some detail.

I. Thomas Morris and Grissie Hewson were married 24th August, 1629.

II. Edward Morris, their son, was born at Nazing, Waltham Holy Cross Abbey, Essex, England, in August, 1630. He was brought to New England by his parents in 1636, and settled in Roxbury, Mass. On 20th September, 1655, he married Grace Bett (parentage unrecorded, but of an English family). They were members of the church ministered to by John Eliot, "the blessed apostle," who baptized all their children. Edward Morris died, in September, 1689, at Woodstock, Conn., whither he went very shortly before his death. He had eight children, four sons and four daughters; of whom

III. Edward Morris, the second son and second child, was born in March, 1658-9. In May, 1683, he married Elizabeth Bowen of Roxbury, Mass. (daughter of Henry Bowen, a Welshman, and Elizabeth Johnson, of English parentage). They removed to Woodstock, Conn., in

* Ephraim and Pamela (Converse) Morris, Their Ancestors and Descendants (privately printed, Chicago, 1894). 
1690-92, where 'Deacon' Morris was prominent in local affairs, and a pillar of the church. Here Morris died in 1727. There were seven children, one son and six daughters; of whom

IV. Edward Morris, the third child; was born at Woodstock, 9th November, 1688. In January, 1715, he married Bethiah Peake (daughter of Jonathan Peake, grandson of an English Puritan settler, and Hannah Leavens, who was also descended from English Puritan immigrants). Like his father, he was a leader in local affairs, till about 1749, when he removed to West Woodstock, Conn. Here he owned a good deal of land, and here he died in 1769. At the time of his marriage he was twenty-seven, his wife but seventeen. There were no less than fourteen children of the union, four sons and ten daughters; of whom

V. Isaac Morris, the second son and sixth child, was born in Woodstock, 26th March, 1725. In October, 1748, he married Sarah Chaffee (daughter of Joseph Chaffee, grandson of Thomas Chaffee, of Hingham, Mass., and Hannah May, great granddaughter of an English sailor who emigrated from Sussex in 1635). About 1762 they removed to Hampden Co., Mass. (South Wilbraham), where Morris engaged in farming, and where he died in 1769, leaving a comfortable estate for these days. He saw stirring times. At the celebration of the centennial of South Wilbraham, in 1863, the historical address of Dr. Stebbins, which makes frequent reference to Isaac Morris and his family, contains the following passage.

"Burt tells his vigorous son to cross the mountains, by Rattlesnake Peak and rouse the Crockers, Cones, Russells, Kings, and stay not till all the men of the South Valley, from 
the corner to Isaac Morris', were summoned to the march. 'Edward,' said Isaac Morris to his son, 'Bring the horse,' and as soon as he had slung his powder-horn over his shoulder, put his bullets into his pocket and taken down his trusty gun from its hooks, the faithful steed was at the door. Breathing a prayer for his heroic wife, standing by in a speechless submission, he was off at full speed on the track of young Burt, ... Before sundown, thirty-four men were on the 'Great Bay Road,' hastening to defend their rights, but the 'red coats' had returned to Boston, and our 'minute-men' returned home after ten days."

Isaac Morris, who died in 1778, had twelve children, seven sons and five daughters; of whom

VI. Ephraim Morris, the youngest child, was born in South Wilbraham, Mass., 17th March, 1772. Left fatherless at the age of six, he was placed under the guardianship of his brother, Isaac, nineteen years his senior, who resided at Monson, Mass.

"Of this brother he often spoke with the utmost regard, from the remembrance of those principles which he inculcated and which had much to do in the formation of his character."

He was apprenticed to the tanning trade, and was master tanner at twenty-one. Some time prior to his marriage, he settled in Stafford, Tolland Co., Conn., where he remained till 1804-5. In October, 1776, he married Pamela Converse (daughter of Jesse Converse, of the fifth generation in descent from Edward Converse, who came from England with Winthrop, in 1630, and Mary Moulton, probably of Nova Scotian (English) ancestry). She "was a handsome woman, light complexion, blue eyes, tall and very fair, kind, gentle, and beloved by all." She irradiated gracious influence till the very last-her death took place in 1846. Attracted 
by reports of the fertility of lands in Braintree, Vermont, one hundred and eighty miles north of Stafford, Conn., Morris bought 136 acres of woodland wild, in Roxbury, Washington Co., Vt., in 1804, and migrated thither. I suppose he was more or less deceived by 'wild catting'; in any case, a Morris was beaten for once. Meeting with no success, he removed to Bethel, Windsor Co., Vt., in 1812. Having purchased a two-story house, he "added many improvements, and in 1825 brought on his shoulders from Squire Marsh's sugar orchard . . . the small saplings which have now grown to be the large maple trees standing in front of the homestead, shielding, as it were, the old home and sacred memories of their master gone so long ago. . . . He also improved the homestead with a slant roof and a one-story addition in the rear, setting on blinds and painting the outside white, making the appearance quite attractive. This was ... the rendezvous for children and grandchildren at all times of the year, and all freely confess, the best visits of their lives were those made at the old homestead."

This is the place where we hear early of George Sylvester Morris-"playing hide and seek with his younger cousins all over the house, and seeming to like it as well as they." Ephraim Morris pursued the tanning business with success and, although he held few public offices, he was "one of the prominent and influential men of the town, well thought of and much respected. He was a great admirer of Henry Clay and Daniel Webster, and by many was said to resemble the latter. In politics he was Federalist and Whig. His complexion, hair and eyes were dark; above the medium in height, and a large head." He died in 1852, and his funeral sermon records:

"If he moved at all, it was in the front rank. And seldom did any laudable and benevolent undertaking call in vain 
at his door. . . . He died as he lived, in the exercise of the fullest confidence in the principles of experimental religion. $\mathrm{He}$ indulged no idle vagaries. . . . Possessing a clear and discriminating mind, together with an uncommon degree of energy, regulated by his knowledge of men and things, and by those Puritanic principles which he early imbibed, he proved himself a man of sterling worth."

Like his father, Ephraim Morris had twelve children, six sons and six daughters; of whom the eldest was

VII. Sylvester Morris, born in Stafford, Conn., 23d Sept., 1797-a babe destined to become an unusual man, the most noteworthy, in many ways, of all his people; the intensity of the New England conscience, with every quality and defect of quality, palpitated in his massive personality. To be so fathered was something. But it was not all. On 1st August, 1822, Sylvester Morris married Susanna Weston, a descendant of the Westons and Washburns, of Middleboro', Mass. She had no less than six direct ancestors, on both sides of her house, aboard the Mayflower. The English Pilgrim strain was thus reinforced once more. For, "Susanna was . . . small and fair in appearance, with blue eyes and delicate features, and a religious nature the depth and fervour of which brought her into closest sympathy with her husband. If he had the militant virtues of hero and martyr, she, like her mother before her, was a saint, with an intensity of devotion and a depth of religious experience uncommon even in women."**

Her family "were known for a certain refinement and love of learning uncommon in that time and region." $\dagger$ Mr. and Mrs. Morris had eight children, five sons and three daughters; of whom

* A Sketch of the Life of Sylvester Morris, by his granddaughter, Kate Morris Cone, p. 16.

$\dagger$ Ibid. 
VIII. George Sylvester Morris, the subject of this biography, was the youngest child. He was born on 15th November, 1840, in Norwich, Vermont, a village just across the Connecticut River from Dartmouth, New Hampshire-place, like race, was to have important bearing on his career. 


\section{CHAPTER I}

\section{The New England Home}

More than a quarter of a century has elapsed since George Morris died, cut off untimely. Subsequent movements of every kind have been so momentous, so unforeseen, that he may appear remote already. But it is not so. For, taking a few significant names at random, we must remind ourselves that he was born in the middle of the decade which gave us Thomas Hill Green, Grover Cleveland, Swinburne, Marcus Hanna, J. P. Morgan, Henry Sidgwick, Zola, August Bebel, Tschaikowsky, William James, Andrew Lang, George H. Darwin, and Thomas Edison. In other words, he survives, with the men of his file, part and parcel of our puzzling epoch. Yet, so enormous have been the displacements these last seventy-five years, especially in the United States, that a great effort of imagination is necessary to reproduce the pioneer conditions of 1840 . Taking the means of communication only, for example: Sylvester Morris was two years old ere the first road was laid through that section of southeastern Vermont; his son had turned nine ere the first railway offered a precarious service. Boston, reached by two-horse sleigh, the very snow favouring travel, marked the limit of a difficult journey, ventured at long intervals; and was the terminus-the veritable hub then-of the universe. Fortunately, Mrs. Cone has preserved a vivid picture of Sylvester Morris, based on intimate personal recollections: and, starting from this, it is possible to recover 
many of the circumstances that moulded George Morris from the cradle on to early manhood.*

Sylvester Morris was seven years old when his father, returning to the pioneer traditions of the family, migrated into the wilds of Vermont.

"Although no record of it remains, the journey thither, long and difficult as it was, doubtless made its impresslon upon Sylvester's childish mind. The distance was two hundred miles, and was accomplished by waggon, and probably, also, partly on horse-back. . . . The region was a mountain wilderness, recently and sparsely inhabited, destitute of churches, without regular communication with the outside world, and with the humblest and poorest conditions of life. . . . In these years, however, fell the most impressionable period of Sylvester Morris's life. In Roxbury he grew from a child of seven to be a tall youth of sixteen, his character nearly formed, his school-days ended, and what was to be of the greatest importance in its influence on his whole after-life, his career as a Christian begun. . . . It is probable that he went to school in district No. 1, which had been set off by the town in 1801. What he studied, and who his teachers were, we do not know . . . he was all his life an intelligent reader, an excellent speller, a fair penman, with correct and dignified methods of expression, and sufficiently versed in mathematics for the conduct of business. . . . His religious training was accomplished under even more primitive circumstances, for the settlers of Roxbury were more loyal to Puritan traditions in their schools than in their churches. . . . Religious services were meanwhile conducted by itinerant preachers, and held in school-houses or barns, or, like the town meetings, in neighbourhood kitchens. At some revival, in some such place, in the midst of neighbours and schoolmates, Sylvester Morris, a boy of twelve, took the stand as a Christian which he was to maintain with unusual

${ }^{*}$ A Sketch of the Life of Sylvester Morris. Kate Morris Cone. Privately printed; Boston, 1887. Mrs. Cone is a daughter of Ephraim Morris, third son and fifth child of Sylvester Morris, and is therefore a niece of George Sylvester Morris. 
sincerity and manliness the rest of his long life-seventyseven years."

\section{Ephraim Morris, his father,}

"had, and most of his children had also, a well-developed social sense, a wholesome regard for good blood and good breeding, and the tolerant spirit towards human failings essential to the fabric of social intercourse. He was proud of his family connections in Connecticut, and scrupulously kept up an interchange of visits there. Like most men of his time, he was not averse to the use of spirituous liquors; his daughters attended once a year the balls of the region; and he was a conservative in politics, and grieved and mortified at the radicalism of his eldest son.

"In contrast with all this was the earnest and exalted character which Sylvester Morris, as he came to manhood, displayed; from the outset totally unconscious of social distinctions, a man to whom the sole realities were God's providence and the responsibility of man to God, and who tried everything, great and small, in the absolute balance of right and wrong. He had a strong body, a great head,his hat was as large as Carlyle's father's,- -and a nervous energy which displayed itself in the very touch of his hand and sound of his voice. He was afraid of nobody, he courted opposition, and, serious and severe as he was, he had a kind of rough humour and a keenness of insight into the weaknesses of others which he used without mercy. Intellectual toleration, gentle breeding, and the amenities of life he neither possessed nor regarded. A radical by the very constitution of his mind, he appeared to some as a Philistine, a fanatic, an impossible absolutist in this sphere of mixed relations; yet in a far truer light he was a hero, and a citizen of the world of most exalted moral ideals, with the temper of the martyr in him. He was called, however, neither to martyrdom nor glory, but, like many another man of his time, to be for forty years true to his principles amid the commonplace surroundings of life in a New England country town, for the most part the sole exponent there of absolute justice and right on the two great social questions of his day,--slavery and intemperance. . . . 
"He was a man of affairs in business. Like his father, a tanner by trade, he displayed great shrewdness and ability in the establishment and conduct of not a few enterprises of importance. . . . With this real business ability and lavish expenditure of effort, there were, however, combined a certain carelessness and generosity which, fine traits as they were in his character, did not contribute to his pecuniary success. ... His services were greatly in demand with widows and orphans, on account of his business integrity and well-known habit of doing better for others than for himself, and in his dealings with the poor some of his noblest traits came to light.

"In the religious life of the communities in which they lived, his wife and he took a leading part, with the enduring faithfulness in attendance on the ordinances of the church, which is the ideal of the Calvinistic system. 'Here I have stood for forty years,' some one remembers him to have said at prayer-meeting; and Susanna Morris, guiding the unwilling steps of her little boys to prayer-meeting on pleasant summer nights, remains an example of religious duty personified. He was a deacon in the Congregational church, at Norwich, for thirty-seven years, and according to a custom, since fallen into disuse, was wont to sit beside his pastor at prayer-meeting, and lead in prayer. On these occasions his tall form and mighty voice, as he stood with head uplifted and arms outstretched, made a memorable impression on the younger generation that beheld him. . . . The Sabbath was observed with a strictness which scrupled at even the picking of a flower; and the head of the family had all a Puritan's objection against games, from authors and checkers downwards.

"According to the temperament of the different members of the family, this plain living and high thinking produced its impression. It had its dark side, in which are combined memories of the lack of beauty and grace in life, occasional sharp words and rebukes from the mother, the father's seasons of mental depression and fits of the blues, the stern punishments in which whippings followed prayer, and a general distaste for the family radicalism which mortification at the father's loud, long prayers, and great hands stained in 
the tanyard, went far towards fostering. Yet, on the other hand, one cannot forget on how high a plane the family life ran, or how rich it was in spiritual suggestion and religious aspiration. . . . Whatever their way of life, not meanness and stinginess, but a noble and unselfish generosity was at the heart of it. . . . All that is sacred in the associations of religious instruction and worship, Sylvester Morris and his wife afforded their children. He was the Puritan father at the head of his family, and the spirit which is the very essence of New England institutions breathed in that home. . . .

"But his life-work, and the thing for which he is to be especially remembered; was his position regarding the two great social questions of his day. He was the local apostle of anti-slavery and temperance in the towns in which he lived, and threw himself into the promotion of each cause with all the energy of his strong nature. On both subjects he took extreme and absolute ground, regarding total abstinence as the solution of the temperance question, and slavery as a crime against the inherent rights of man. . . . He became a sort of public conscience, a 'character,' in the streets and public places of Norwich, and no occasion was too common or adversary too high or low for his attacks. In the post-office and village store he was almost daily to be seen, the centre of an amused and applauding group of lookers-on, preaching righteousness, and applying to some individual the most searching personal inquiries. . . Between Dr. Lord, the shrewd politician, president of Dartmouth College, and him, there was at first a strong bond of abolition sympathy, broken, of course, by Dr. Lord's final going over to the enemy, which, inexplicable as it seemed to Sylvester Morris, taught him charity, he said, because he knew Dr. Lord for a good man. Towards the professors at Dartmouth he felt varying degrees of antagonism, partly on religious and partly on political grounds. . . . As regards that famous institution, by which many a fugitive slave was handed on from one friendly house to another, public sentiment in Vermont was too undecided, and the Canada line too near, to make the harbouring of slaves in Norwich particularly dangerous. Danger or not, a room was devoted to such guests in the 
Morris house, and there, sometimes for several days, the poor creatures were sheltered, the women often gladly taking part in the work of the household. . . . The service was simple enough, but by it Sylvester Morris was linked to a line of friendly hearts which stretched across the Union, and the sight of the poor, trembling, often maimed and lacerated fugitives, afraid for their lives of capture, and especially warned against Dr. Lord, at Hanover, fanned the flame of indignation at their oppressors.

"It is unnecessary to say that in politics Sylvester Morris stood with the extreme Abolitionists. ... He took the Liberator; and the arrival of the National Era, with its instalments of 'Uncle Tom's Cabin,' was an event in his household celebrated by the assembling of the whole family to hear it read aloud. His indignation at the position of the churches towards slavery, and the famous petition of New England ministers, knew no bounds. 'Fools, lick-spittles, cowards!' was only a slight expression of his opinion. . . . He outlived by more than twenty years the triumph of the anti-slavery cause, but he was also a witness to nearly as great a revolution in public opinion regarding intemperance. In the days of his early manhood and prime, the punch-bowl was the ornament of every sideboard, and the offering of wine a necessary hospitality to every guest. He lived to see liquor of all sorts banished from the majority of households, and the temperance element in politics a factor of importance."

When it comes to criticism, a man so zealous and intolerant as Sylvester Morris, a culture so stiff and straitened, are all too easy marks. The harsh judgments they evoked have had their day long since, from Samuel Butler down.

\footnotetext{
"A sect whose chief devotion lies

In odd, perverse antipathies;

In falling out with that or this,

And finding somewhat still amiss; ...

Compound for sins they are incline $d$ to

By ramning those they have no ? ind to."
} 
One would do better to adopt the reflection of a great thinker, when he bethought him of his pious parents, from whom he differed widely. Kant wrote,

"The religious ideas of these times, and the prevalent notions of virtue and piety could hardly be said to be either clear or satisfactory, but the root of the matter was in them. Say what you will of Pietism, no one can deny the sterling worth of the characters which it formed. It gave them the highest thing that man can possess-that peace, that inner harmony with self which can be disturbed by no passion. . . . Even the casual observer was touched with an involuntary feeling of respect before such men."

But, for our present purpose, even this is insufficient. Sylvester Morris partook in the spirit of those remarkable New England leaders, the early preachers. The forces that bred John Cotton, Thomas Shepard and Thomas Hooker among the clergy, the Winthrops, Thomas Dudley, Simon Bradstreet, William Brewster, Pynchon and John Haynes among the laity, were once more victorious, even if sad, in this latest hero of the direct line. Sylvester Morris was the last, or almost the last incarnation of a race of thinkers whose theological beliefs determined their political aspirations. To understand him, and to appreciate the influences that went to the making of his son, we must attempt to grasp the history and import of the outlook that could become so uncompromising, masterful and, in its way, unique.

Whatever may be said in praise or derogation of English and American Puritanism, it was certainly a distinctive expression of race-consciousness. So much so that, had the little craft which lay in the Thames estuary with Cromwell, Hampden and Haselrig aboard, been fated to bear its precious freight to Massachusetts Bay, the subsequent history of the Motherland might 
have run very differently. And, like every significant change, long wrought secretly in the womb of a people, Puritanism drew upon many sources of nourishment. Accordingly, it achieved various culminations. Cromwell, Milton, Baxter and Bunyan were its most articulate representatives, while, in New England, under far other conditions, it brought forth a society peculiarly its own. The Massachusetts, Connecticut and Rhode Island colonies possessed their several traits, because the political genius of Cromwell, the intellectual genius of Milton, the theological genius of Baxter, the social genius of Bunyan travelled overseas, and reproduced themselves as formative elements in the young communities. Massachusetts stood nearer the CromwellMilton-Baxter interests than Rhode Island, which, in turn, drank deeper from Bunyan. But, when society in the new world struck its own stride, all these factors were readjusted. As an alchemist would have put it, the physical circumstances, the economic conditions and the untrammelled political idealism of New England furnished an original menstruum for a novel combination.

The resultant precipitate is not hard to detect. In these compact, isolated groups, the English race attained a fresh consciousness, which operated so acutely that mere 'common' individuals became more than themselves, adding a cubit to their stature. The general level was wonderfully high, because every man apart nourished his character upon aims for which all had striven passionately. Hence, conspicuous achievement became a normal condition-personalities abounded, where every man was thoroughbred in a communal culture. The average citizen forced a reckoning, because the power of the many coincided with the performance 
of the one, and the principle of indifference, enunciated so soon in England, by Locke, could strike no root. This, indeed, gives the key to the situation. As Shepard said, "It is Satan's policy to plead for an indefinite and boundless toleration." And Dudley, emotion moving him to rhyme, wrote,

"Let men of God in courts and churches watch O'er such as do a toleration hatch."

In short, the Puritan culture loved to dwell upon extremes - a mean was anathema. Life can be split into virtue and vice, for, where man is a creature of wrath, all days are Sabbaths. Civil government, statute law and social intercourse are, no less than religion, under the immediate eye of the Great Task-Master. Hence it was important that the socio-politico-religious systems of the old world, whether swayed by an omnipresent Laud or by a remote pope, should be met by a like and, if possible, more pervasive organization. But a social structure of this kind must needs be supported by legal sanctions. These, again, lay ready to hand, forged by the internal temper of Calvinism. Political freedom as developed in Europe was an achievement of the small, intense national groups. And, even more than the Swiss, the Scots and the Dutch, the New England 'minute men,' worthy sons of their fathers, are indebted to Calvin for their conception of autocracy. Almost two generations before Rousseau and the Declaration of Independence, John Wise, from Roxbury, the Morris home, had made this fact plain.

"The end of all good government is to cultivate humanity and promote the happiness of all, and the good of every man in all his rights, his life, liberty, estate, honour, and so forth, without injury or abuse to any."**

*A Vindication of the Government of New England Churches, p. 42. 
But words are meaningless save for the ideas they convey. And, with the Puritan, 'virtue,' 'vice,' 'freedom' do not belong to the sensuous world; on the contrary, they imply complicated standards of judgment, always capable of adjustment, always in need of vindication, in short, always stimulating to the intellect. So, like every system, Puritanism developed its paradoxes. On the one hand, it elevated man to a plane of copartnership with God. Life here below acquired unutterable seriousness, because a holy people was chartered to execute the Divine will, and therefore to stand forth superior, an example to the whole earth. Civil institutions-the state and, more emphatically, the familywere sanctified. The very suggestion of provincialism took to flight, for, "we are the people, and wisdom will die with us." Blasphemy and adultery, the latter including all social lapses (innocent amusements no less than gross indulgences), threw the other commandments into shadow and, I fear, sometimes brought total eclipse upon the Beatitudes. Amenity did not exist. A mere moment between two eternities, a moment of preparation against the wrath to come, life held no place for such trifling. In short, a certain state of psychological being, not a 'thing' among other sensible things, but a steadfast condition of mind, was the dominant ideal. A consuming passion, having free course and glorification, provided the motive to make this ideal actual. Il n'y a que de grandes passions que fassent de grandes choses. But, man, being what he is, cannot put off environment. The pursuit of a spiritual purpose is bound to alter sensuous things.

So, on the contrary, Puritanism, a mood of otherworldliness, came to be beset by a worldliness of its own. 
The Lord had commanded, "Enter in and possess the land." To be free, a man must be a freeholder! To sustain his mission, he must necessarily sustain himself! And, naturally enough, the asceticism of toil brought a double reward. It not only toughened the conscience, but enabled the citizen to boast, "The rent-day doth not trouble us; and all those good blessings we have . . . in their seasons, for the taking." In due time, the tendencies of the spirit gave form, if not comeliness, to modes of social intercourse, to industrial relations and to the training of the youth. The New Englander fitted his infinity to the finite, and entered upon his great destiny - the political, moral and economic control of the United States. In 'God's country' the people of God must bear rule and, perforce, eschew beliefs too lofty for adjustment to average affairs.

Yet, even so, the Puritan gave more than he received. His fearlessness and conviction shaped circumstances; a peculiar civilization was created. Thus, taking the Morris household,

"Sylvester Morris was as liberal with money as his circumstances permitted him to be, and his large-hearted confidence and trust in his sons is among his most precious bequests. They were trained at home, too, both by example and discipline, in the most important principles of public spirit and obedience to authority. If the boys were punished at school, they were punished again at home, and the maintenance of the church and other public interests was strictly inculcated.*

Dutiful obedience to the Heavenly Father, a matter of belief, was translated into dutiful obedience to the earthly father and to all institutions whereof he had been made free, a matter of practical arrangement.

* Mrs. Cone, Ibid., p. 22. 
As the finger of the one could be traced in every dealing with man, so the authority of the other must be accepted. Both were mysteriously unaccountable; but, whereas a reckoning with the former partook of flat blasphemy, it might arrive with the latter, 'practical politics' so conspiring. Accordingly, thanks to the temper of its civil government, the intensity of its family life and the norms of its social control, New England Puritanism assumed the character of a stable environment, one no less formative than climate, soil or untamed nature.

Now this is to assert that it passed rapidly from theory to practice, from exercise of the intellect upon the Scriptures to discipline of the will within the home, the church and the vocation. Hating Romanism with a perfect hatred, it nevertheless bred a catholicism of its own-not a theory, but a way of life penetrating to every corner of the average career. As Herder said of Romanism, "A cross, a picture of Mary with the child, a Mass, a rosary, were more to its purpose than much fine speculation." So, too, with the New England Puritan: a "grim happiness," a secular decorum, a naïve democracy and a sharpened thrift in an industrial home incited him to unbroken effort long after his abstruse theology had come to be taken for granted. He inherited his theories, and had little, if any, firsthand knowledge of the intellectual processes whereby they had been reached. His institutions, on the other hand, were his own, to do with as he deemed best; and the struggle for independence, the war of 1812, like the Homeric battles 'in the West' for the preservation of the Union, confirmed this sense of active ownership in rights, based on personal sacrifice, and always for a larger whole. Thus, while he had patience and long- 
suffering with the urgent affairs of common life, he lost the patience necessary to the criticism of particular doctrines, much more to the justification of a Weltanschauung. And yet, despite the paradox, the framework of his daily round was itself the issue of a lofty experience, of a theory which could animate a race, even although nowise capable of proof, and therefore destined to shipwreck sooner or later. In the midst of Nature, and with the humble tools of a world he affected to despise, the Puritan built him an earthly habitation, unwitting that these non-human 'creatures' could never be adjusted completely to transcendent intuitions. His ideals were doomed to pay toll. For, his common life sustained an uncommon quality, while his uncommon theories sank inevitably to the level of pseudo-philosophical commonplaces.

By the time of the fourth generation from the first immigrants-that of Isaac Morris-such a man as Charles Channing (1705-87) serves to show how the wind was blowing. His sermon on Enthusiasm (1742), a tremendous castigation of the Whitefield movement, already presages the revolt that was to manifest itself in Unitarianism. Not only this. It is a trumpet call back from giddy speculations to the quiet orderliness of daily life prevalent in New England.

"The enthusiast is one who has a conceit of himself as a person favored with the extraordinary presence of the Deity. $\mathrm{He}$ mistakes the workings of his own passions for divine communications; and fancies himself immediately inspired by the Spirit of God, when all the while he is under no other influence than that of an over-heated imagination.... And various are the ways in which their enthusiasm discovers itself. ... Sometimes, it will unaccountably mix itself with their conduct, and give it such a tincture of that 
which is freakish and furious as none can have an idea of, but those who have seen the behaviour of a person in a frenzy. . . And what extravagances, in this temper of mind, are they not capable of, and under the specious pretext too of paying obedience to the authority of God?"

Vain theories serve only to promote confusion. Therefore, let the New Englander stick by what he has proven. Rectitude in the home, in business, in politics, and regularized means of grace, are the sound basis of permanent stability. In brief, there is a civilization now, and it is not to be disturbed. The practical achievement has advanced to the impregnable position once in lonely occupancy of the theoretical presuppositions.

In small, rural communities, which the excursions of pioneers perpetuated, theory and practice kept step till after the Civil war. Religious idealism, with its theological background, controlled secular affairs. Despite hard toil from Monday to Saturday, the family was stayed upon the church and, with the 'elect,' neither social customs nor politics were divorced from the 'Covenants'.

"To them prayer was something more than a devout soliloquy, or an exercise in spiritual gy mnastics valuable only for its reactionary effects. When they prayed they thought that they moved the hand that moved the world. They spoke of direct answers to prayer as one of the usual and indubitable facts of almost daily experience."*

We must inquire then, What were the conditions within which home life moved till G. S. Morris was a youth?

Leaving political 'freedom' aside-not then, by the way, bedraggled under the régime of Bosses, Tariffs and Trusts - the home, neighborhood industries and Congreg101.

*A History of American Literature, Moses Coit Tyler, Vol. I., p. 
ationalism were the familiars, as they were the outgrowth, of this pioneering Puritanism. And, although limited by restraints that we should deem intolerable now, people were by no means hopelessly provincial even in the days "when folks was folks." They engendered, and preserved, a culture of their own. Thus, is is necessary to insist that the 'home' is an ethical, not a material, fact. Emotion, intellect and social wellbeing constitute it, an aggregation of physical objects being no more than incidental. And, if it pivots upon the father in one way, in another it is subordinated to the nurture of the children. Hence, in turn, the indispensable part played by the mother. Here we may detect at once its qualities, when it bore exclusive rule, and its difficulties, when it tried to adjust itself to a larger order. For the claim of the family group upon its individual members takes a sweep that defies statement in the conventional ratios of commerce. The 'cash nexus,' with its impersonal finality, has no meaning here. Thus, inevitably, even if unconsciously, the home tends to tyrannize, to become the only good. And when, as in New England, it was the actual unit of society, it could not fail to exercise an unchallenged dominion. Thrift in business, regularity in waiting upon religious ordinances and the constant effort to 'be a credit to parents' provided a series of moral standards so distinct as to be capable of classification under the term 'domestic.' Moreover, these prevailed, as they sufficed, till the years immediately preceding the modern industrial revolution. A profound idealism, international in its scope, with generations behind it, and therefore metropolitan, not provincial, was accompanied by the simplicity of life made possible by the 
absence of a complex social order. Despite the pressure of economic circumstances, man could conduct his career fearlessly, for the greed of acquisition had not laid fatal hold upon him. The unpretentious white house, surrounded by common flowers, its kitchen-garden unconcealed, its berry bushes crowding the fence shamelessly, betokened the life within. Nor did the titillating distractions of later days exist - when we

“. . . . see all sights from pole to pole, And glance, and nod, and bustle by;

And never once possess our soul

Before we die."

Newspapers were few, and these few not plethoric; theatres, shows, popular entertainments in the way of lectures or concerts, 'movies,' and 'the greatest novel of the year' (published one per day as per advertisement), there were none. Consequently, the home not only bred its gracious, if sheltered, virtues, but also provided innocent and quiet relaxations. Here, again, its solidarity, and therefore supremacy, found reinforcement. For, in pleasure as much as in toil, graybeard and youth joined. Nay more, amusements that originated or lay outside this range came to be suspect by the very fact.

Little wonder, then, that one nurtured in this home acquired something larger than mere separate individuality. He grew to be the representative of an entire system of ideas, which gave colour not simply to thought and conduct, but to the worth of all aims deemed fit for human devotion. T'rue forcefulness consisted in quick response to a series of very definite judgments. That is, the moral consciousness characterized, even when it failed to determine, the status of all relations. Everybody is aware that even now, to the remotest corners 
of the United States, the clean-run New Englander betrays himself by this home-made scale of esteems and disesteems. The horizon of any life capable of yielding satisfaction is bounded by a dutifulness that knows no bounds.

Once more, New England was a relentless school of compulsory labour-a land of 'chores.' A society whose economic foundation was the small holding, whose commerce hummed in home industries, promised work, and to spare, for all. Children did not appear 'encumbrances,' there; on the contrary, they were a "heritage of the Lord."* In due time they would take their places alongside father and mother, valiant recruits for the common prosperity. When it was not tilth that cried for hands, it would be a modest industry-a tannery, perhaps, or a saw mill, a grist mill, a cooperage where dairy and sugar-sap utensils were fashioned, a harness shop, or a general store. And, round the hearth, the womenkind carded and spun, knitted and did needle-work; churned, saved the wood ashes; salted the pork for domestic consumption or with an eye to a fine barter, when the pedlar appeared on his rounds. $\dagger$ Thus, the industries of the family, in common with other aspects of its activity, were dominated by the idea of duty - self stood in definite relations to other selves, to the corporate whole. This inspired all, mother and daughters no less than father and sons. The life was of, from and to the group. 'Big business' they did not

* The six New England generations of the Morris line are quite typical here. There were sixty-one children, an average of 10.3 for each succeeding family.

† Cf. American Thought from Puritanism to Pragmatism, Woodbridge Riley, pp. $291 \mathrm{f}$. I greatly regret that this book appeared after my MS. was completed, otherwise I could have derived much aid from it. 
know, but such business as they had was apt to be, and all unconsciously, the shrine of an ideal. And, so once more, by industrial as by social relations, a distinctive type came to be produced; the individual, ordinary otherwise, found himself caught up and transfigured by the 'over-individual.' Above all, the illusion, that a man may fashion his own destiny, found no congenial soil. For Necessity, the mysterious power behind the Fates who spin the mortal thread, as Plato tells, presented itself not merely in external circumstance, but under more august mien.

A culture so pervasive as to control the main issues of life can scarce win authority,-cannot be brought to birth, perhaps,- - unless it have an infusion of wisdom. Now wisdom is insight into the ultimate ends for which things exist, or grasp upon the system of truth. As such, it presents three sides at least. It must needs appeal to the whole manhood-to intellect, feeling and will equally. No doubt, in the narrower sense, it has been associated with the first, and is often confounded with mental acuteness. As a matter of fact, it depends upon character rather than upon capacity and, for this reason, might be associated with will. But, whether for will or feeling, deliberation is its antecedent condition, education its proper function. The intellectual reference thus asserts itself, and may be left to take care of itself,no dolt can achieve wisdom. Yet, if wisdom is to furnish the means whereby one may 'come at' ideal aims, its educative function must be free to operate all round. Deliberation, mediated by intelligence, will produce insight; mediated by feeling, it will issue in taste; mediated by will, it manifests itself in goodness. And, to its perfect work, wisdom needs all three. This universal gift is rarely, if ever, bestowed. 
One cannot question that the Calvinistic Congregationalism of New England furnished the element of wisdom in the civilization of the folk. On the side of character the issue was goodness; on the side of feeling, issue failed; on the side of intellect, it settled down to a series of mysteries which, nevertheless, bore quite definite suggestions. God had laid necessity upon these men, to find in religion an amplitude of experience denied them through other channels. Their church and its doctrines brought them into contact with the true system of things, giving the average man an education potent to elevate him to a plane of very real cultivation. The ordinances of religion, preaching particularly, formed the exclusive equivalent for the numerous 'aids to knowledge' available now. The drama, the lecture, the club, foreign travel, the free library, the picture gallery, the cheap classic, the proliferant novel, the museum, and the cinematograph found their substitute in the sermon. Till we realize this, we realize nothing. Sermons

"are the most authentic and characteristic revelations of the mind of New England. . . . They represent an enormous amount of subtile, sustained, and sturdy brain-power. . . . are monuments of vast learning, and of a stupendous intellectuai energy both in the men who produced them and in the men who listened to them. . . They are superior to our jests. We may deride them, if we will; but they are not derided."*

Of course, for many-a majority, may be,-among the hearers, the intellectual part of this wisdom was provided vicariously. In the nature of the case, it did become traditional more or less. But, the observances

* Tyler, Ibid., p. 192. 
entailed by it, like the attitude of mind produced, wrought tremendously upon will to the making of character.

Family worship, the father endued with the priesthood of all true believers, prayer and biblical instruction, were everywhere. Children came to know the English Bible by heart-itself a glorious instrument of culture. The Lord's Day, set apart, brought a full round of appropriate duties and prohibitions, while the mid-week Prayer Meeting served as a reminder that the sacred never forsook the secular. Constant contact with noble thoughts, however conventional, and a memory filled with noble words, could not be void of effect.

"What was there in that little mean, square, ugly meetinghouse that it could so easily govern the conduct of the community and draw the tithe of their substance, that could hold their tired bodies on hard benches during four long sessions and make them thankful for the privilege! It was because, humble and mean though it might be, it was the shrine of an ideal beside which substance, nay even life itself, is but a watch in the night."**

Here the 'sinful creature' learned of his dread-gladsome calling, as copartner with the Creator of all things, and knew himself for an immortal soul, destined to an eternity before which earthly affairs shrank to mere dust in the balance. Rudeness there may have been, as we now estimate, but the essential genius of the Scriptures was grafted on the heart of the people, bestowing a dignity that we may well envy. Men did enjoy wisdom then, because, sure of themselves in prompt judgments, they set right and wrong poles asunder. Esthetic taste had to endure neglect, intellect often

*When Folks was Folks, Elizabeth L. Blunt, p. 58. 
wore itself out upon impossible notions, ay, superstitions. Notwithstanding, custom and habit as between man and man displayed a magnificent stability always, sometimes exhaled a fragrant sweetness.

Standing fast in the old ways, the men of real weight had no need to acquire virtue; it came to them naturally through the medium of immemorial tradition. They were convinced-a matter of knowledge-that they possessed character-a matter of emotion. Unaware, they evinced kinship with all great constructive epochs. Thus, what has been said so admirably of the heroic age of the Athenian state applies to them most aptly.

"The truth is that knowledge, as understood by Socrates, has the closest possible relation to character. It is a certain overmastering principle or power that lays hold primarily indeed of the intellect, but through the intellect of the entire personality, moulding and disciplining the will and the emotions into absolute unison with itself, a principle from which courage, temperance, justice and every other virtue inevitably flow."*

Accordingly, the spirit of the group ruled with uncompromising authority, because the citizen was "conscious of being by means of it the instrument that serves the divine working." Touched thus to high issues, representative personalities held what Plato calls 'unshakable' convictions about right and wrong, whether moral or intellectual. Substituting conduct of life for 'style,' Renan's account of his own experience at Saint-Sulpice describes the situation perfectly.

"Sans le vouloir, Saint-Sulpice ou l'on méprise la littérature, est ainsi une excellente école de style; car la règle fondamentale du style est d'avoir uniquement en vue la pensée que l'on veut inculquer, et par conséquent d'avoir une pensée." $\dagger$

* The Religious Teachers of Greece, J. Adam, p. 229.

$\dagger$ Souvenirs de Jeunesse, p. 220. 
Briefly, the particular case of New England was transmuted by the operation of a universal truth, equally potent in pagan Athens, in Romanist Paris, and in the English Puritan colonies. Differing widely in form, the social structure was a structure because, in every instance, the same essential principle prevailed. The great things, as time and sense measure magnitude, were abased, or exalted, by the admonitions of the still, small voice.

No doubt there were dark shadows, the deeper for the very brightness of the qualities, and, thanks to them, the new was bound to clash with the old some day. Yet, taken all in all, it was a heroic community, breeding so true that, when the clash did come, its sons and daughters were condemned to rebuild the temple in fear and trembling, often in dire bitterness of soul. For bereft of so much, they did not understand that no such unity could be created complete and whole within the brief span of a single generation.

Such, then, were the form and pressure of the folk from whom Morris sprang. The story of his career holds permanent interest in so far as he found himself compelled to forsake nigh all the views on which he had been nurtured and, at heavy sacrifice, going out into the infinite alone, to think through to a different standpoint. Like his father, he was a representative man, and so his tale is itself an epitome of many others in his age. He felt

"The Sea of Faith. . . .

Retreating to the breath

Of the night-wind, down the vast edges drear And naked shingles of the world."

But, even though tried severely by this loss, he could not endure a "land of dreams," having "neither joy . . . 
nor certitude nor peace." Thanks to the impress of the New England Home, the spiritual qualities remained the principal thing. And his life work, cut off incomplete at noon, alas, is the record of a vital effort to replace the conventional traditions or incomprehensible mysteries of his youthful training by intelligible, defensible doctrines. He rejected formulæ that had become mechanical, but he could never reject the perennial problems of human nature. He was thus one of the first in the United States to give a new organic structure to the solution of the eternal questions which, as he had been early taught to hold, and as he always held, are ultimately the sole questions. 


\section{CHAPTER II}

\section{School and College}

\section{(1854-61)}

In 1840, the year of Morris's birth, Norwich village was the centre of a township with some 2200 inhabitants. Emigration westward having set in, population had been on the decline for a decade, and was destined to fall to 1700 by the census of 1860 . The population of Windsor county was but 40,000 , and shrinking slightly. The surroundings, quaint to modern eyes, were thoroughly wholesome, and the community homogeneous, although the squire and the deacon might entertain inimical sentiments or represent a social contrast. Roman Catholics, foreigners and negroes amounted to curiosities. A criminal class was unknown, and, I suppose, doors were seldom barred. Farming and fruitgrowing were the principal occupations. Potatoes and oats formed the staple crops; a good deal of corn and some wheat were harvested. Maple sugar must have helped the balance in many homes. Sheep were by all odds the most important stock, and furnished a quantity of wool. More than 2000 cattle grazed the fields, and about 1500 swine were fed. The Ompompanoosic River, a swift tributary of the Connecticut, and a smaller stream, Bloody Brook, afforded advantageous mill sites. Thanks to these, modest manufacturing industries were developed, the elder Morris being interested in several. Tanneries, grist mills, saw mills and kilns supplied the largest items on the industrial budget of the State. 
Still, home-made articles formed no less than 33 per cent. of the value of manufactured products, or, if bricks and lime-hardly possible domestic industriesbe deducted, 42 per cent. In other words, the industrial family, even farming aside, continued to perform a most important economic function.

The Congregationalists, the premier religious body, had organized as early as 1770 and, at the time of the Revolution, had built "the best meeting house in the State." Not till 1835 did the Baptists become sufficiently strong to build, and the Methodists followed one year later. Universalism was a familiar 'heresy.' The Anglicans, too, had some foothold.*

The re-establishment, in 1836, by Captain Alden Partridge, of The American Literary, Scientific, and Military Academy, under the even more ambitious title of Norwich University, $\dagger$ appears to have thrust an element of disquiet, if not discord, upon the rural folk. Mrs. Cone writes,

"The Partridges were a leading family in Norwich from the first settlement of the town. Captain Alden Partridge established Norwich University there, the well-known military school, which was at the height of its prosperity when Sylvester Morris moved to town; and Lewis Partridge, his nephew, was a prominent Democrat in State politics, and became United States marshal under Buchanan. The school was aristocratic and Episcopalian, with many pupils from the South, and the family led the opposition in Norwich which wealth and social prestige everywhere raised against the Abolitionists. Better examples of the two classes in society, which in the North were arrayed against each other in the great struggle, could hardly have been found than elegant,

* Cf. The History of Vermont, with Descriptions Physical and Topographical, Rev. Hosea Beckley, pp. 298 f. (1846).

$\dagger$ Cf. History of Vermont, Zadock Thompson, Part II, pp. 168 f. (1842). 
self-important Lewis Partridge, whose very manners carried weight, and our rough, hard-handed Abolitionist tanner, whom intensity of moral purpose and indignation at the wrongs of the oppressed inspired."

\section{Sylvester Morris's}

"temperance work brought him particularly into conflict with the prerogatives of the University, in the families of whose instructors the old-time hospitality was dear, and whose students were accustomed to soldierly convivialities and the health-drinkings and free liquor of public holidays and reviews. It was one of the glories of Norwich in those by-gone days, the parades of the students on Fourth of July celebrations and militia training-days, when salutes were fired between the two great elms in front of Captain Partridge's house, and dinner and speeches ensued, and the health of the captain was drunk. To oppose these customs, and finally to obtain authority to put an end to the carousals which followed them, roused the bitterest enmity on the part of the students, who spoiled Deacon Morris's garden, cut down his trees, burnt him in effigy at Hanover, and threatened to burn him out."*

Of course, the controversies, in which Sylvester Morris bore his picturesque part, had been stirring for a decade before the birth of his son, George, and they had passed through important phases ere the boy reached years of discretion. Garrison's The Liberator was followed, after nine years, by the Liberty party and the presidential candidacy of James G. Birney, for whom Sylvester Morris voted-one of the stalwart 319 in the entire State of Vermont. Another ten years saw the Fugitive Slave compromise, which old Morris denounced so bitterly. When the Kansas difficulties came to a head George was a Junior at Dartmouth College. In

*A Sketch of the Life of Sylvester Morris, pp. 25, 29-30. Norwich University was removed to Northfield, Vt., in 1867. 
the same way, the commotion caused by the Washingtonian total abstinence societies reached its height so early as 1836-40, and temperance reforms had won their way ere he came to manhood. Nevertheless, these very controversies served to keep the traditional Puritan spirit in fighting trim, and the boy must have been moved by the spectacle. In short, he was raised amidst the influences depicted by the ingenuous Rev. Hosea Beckley.

"The truths of the gospel were circulated in their native simplicity and power; and these truths found reverential hearers ... respecting the heralds of the cross for their works' sake. This is evident from the records of some of their public proceedings, and acts of the rulers in those times. The language of reverence to God and his word is seen in many of their political acts and resolutions. . . . The moral and religious feelings and habits and acts of this people, is the brightest trait in their character. In this respect much indeed remains to be done; many 'crooked paths to be made straight and rough places smooth.' But many heralds of divine message and knowledge have 'run to and fro' these hills and vallies and on these mountains, publishing peace and salvation, carrying glad tidings of good. . . . Girded with the armour of light may they long continue to be polished shafts in the quiver of the Lord, till this whole state become 'a mountain of holiness and a dwelling place of righteousness.'”*

As we have seen, the Morris household preserved intact the the essential spirit of New England Puritanism beyond the middle of the nineteenth century. So, in his tender years, George absorbed its temper, was immersed literally in its influence. He passed through the district school in due course. But, his mother's "inherited love of culture and beauty," well assorted in one respect with his father's religiosity, led to a depart-

* History of Vermont, pp. 283-86. 
ure from Calvinistic neglect of the æsthetic sense. The family loved music and, guided farther by the taste of the third daughter, Lucy, the lad obtained some musical education. It is to be remembered that, although the Puritan turned his back upon the arts, as "the devil's frippery and seduction," he could not dismiss music utterly. Secular music he may have banned, he must needs sing in meeting and family worship. And if his music, like his rhymed psalms, * were quaint, it partook in many of the characteristics of folk song. While it excluded the sublime and dainty things of composition, it nevertheless gave expression to strong human emotion, and possessed a certain inevitableness, just like the 'auld Scotch sangs.' Indeed, it ran parallel to the ballad in poetry. A people face to face with continuous warfare, or preparedness for fight, cannot but break into rough ballads. Crude specimens of poetic art they doubtless are, but they lend form to vital incidents. Similarly, the tunes set to 'psalms and hymns and spiritual songs' performed a function for the religious life. Accordingly, it is nowise surprising to learn that although George Morris

"was largely self-taught in music, important contributory assistance must have been derived from the musical taste of his family in general, and from his sister Lucy in particular. They were all singers, father and mother, uncles and aunts, brothers and sisters, and even I can remember their singing together at family reunions, and on Sunday evenings and at family prayers. Sylvester Morris had a big bass voice, and certain hymns will always have the association for me of his relish in singing them, rolling them out with his head thrown back. The singing was mainly of hymns and anthems, derived from the tunes used in the singing-books of the day,

* Cf. The Bay Psalm Book. 
and a tuning-fork was used to get the pitch; but I think the more popular secular songs of the day, such as were found in collections, were also familiar in the family. Lucy was George's next older sister, and they were near to each other, not merely in age, but in taste and temperament. She was passionately intellectual and musical. A piano came into the house about the time, I fancy, when she was able to use it, and whatever instruction she had must have passed on to him. . . . At St. Johnsbury, Vt., where she taught school, she studied music with Mr. Charles Dana, a blind musicteacher, of much local reputation. . . . . While George was a tutor at Dartmouth before he went to Union Theological Seminary, he used to instruct his nieces (my cousin Susan Kellogg and myself) in music, and always took much interest in what we played, supplying us with music. My earliest recollection of him is as playing the piano, and in a manner which thrilled and educated us all. George's music was one of the joys of my father's life. . . . His beautiful music was a joy to us all. He would play by the hour, completely expressing himself through that medium in a sympathetic environment."**

It is evident then that, from boyhood, Morris was familiar with one approved art that might very easily lead to the realms of a culture unheeded by ascetic Puritanism.

From the Norwich district school he passed to Kimball Union Academy (founded, 1813), Meriden, New Hampshire, where he was prepared for Dartmouth College. Mr. H. C. Morrison, State Superintendent of Public Instruction in New Hampshire, has been good enough to give me the following information.

"Kimball Union has been steadily, from Professor Morris's time, one of our most effective and useful institutions, and it probably never has been so prosperous in its history as it is at present. At the present time it is going through a process

${ }^{*}$ Letters from Mrs. Cone. 
of adjustment to changing community needs, and while it will continue to give a classical curriculum leading to college, it will also, beginning with the present academic year (191314), offer well-grounded curricula in household arts and in agriculture. It has recently come into possession of a rather extensive farm which can be operated in connection with the school, and its opportunities in the direction of sound education leading to the life work of home makers are unrivaled. The newer work will be under the direction of specially trained teachers and I look forward confidently to a period of greatly increased usefulness, without in any way detracting from the traditional work of the school; and I hope that the ancient traditions of plain living and high thinking will be enhanced rather than otherwise."

Intimate recollections of Meriden school days, such as Morris alone could have given, fail us. But, thanks to Mrs. Cone, a number of illuminating details are available.

"George Morris entered Kimball Union Academy at the beginning of the fall term, 1854, three months before his fourteenth birthday. He was the last of his famuly to leave home. Susan was married and in Illinois, where her husband, E. B. Kellogg, had charge of the construction of the P. and O. R. R. Edward was with his brother-in-law in Illinois, a civil engineer. Ephraim was at Hartford, Vt., beginning the development of the water-power there with his fatherS. Morris and Son. Lucy had been for two years at Mt. Holyoke Seminary and was a teacher. For George to enter Kimball Union Academy as a college preparatory student was a new departure in the family. Edward and Ephraim, and their brother-in-law Kellogg, had been educated at Norwich University, General Partridge's military and engineering school. George early showed an aptitude for study and music and, we surmise, was further influenced by his father's growing disaffection toward the authorities of the University (on the Mexican war, slavery and temperance), by his mother's desire to have one son a minister, and by his sister Lucy's intellectual tastes and force. She was George's 
mate in the family, five years his senior, musical, a brilliant scholar, but fretted by the limitations then imposed upon her sex. George could do what she was prevented from doing, and as one opportunity after another opened before him, she entered into his development and had faith in his ambitions as though they had been her own. She died, alas! of a long and painful illness (tuberculosis) just before he received his first appointment at Ann Arbor.

"In 1854 the Academy at Meriden was one of the best of its kind in New England. Cyrus S. Richards was Principal, and in the middle of his long term of office, thirty-six years. The average number of pupils during that period was two hundred, and there were often over three hundred. The school had been founded to help Christian young men, poor and promising, to fit for the ministry. Dr. Richards himself represented a type of student well known there,-a poor boy, from a Vermont hill-farm, possessed of the thirst for knowledge and an ambition to become a minister; working his way through Kimball Union Academy and Dartmouth by teaching school. He was made principal the day that he graduated from college and, though afterwards ordained, made teaching his life work. Under him the school became widely known for its strict discipline, its high moral and religious tone, and the excellence of its preparation for college. 'Powerful and precious revivals of religion' were frequent, and 'converted at Meriden' could be said of very many of its pupils.

"Then, as now, the Academy stood on a hill-top in a remote New England village, on the east side of a sloping green, around which were situated the Congregational church, certain dwelling houses and dormitories, and the village tavern. There is a fine view to be obtained of Ascutney Mountain to the south-west and Croydon Mountain to the east, but for the most part the place is bleak and windy, and bitter cold in winter. The Academy building was of brick, with a white wooden belfry. On the first floor of the main building was the Chapel, furnished with stationary wooden seats descending to the teachers' platform. On the second story, and in the ell, were the recitation rooms, likewise 
furnished with wooden seats and desks, elevated in the rear. The students lived in near-by dormitories and in private houses. Many worked for their board or boarded themselves. Its lonesome situation, its meagre appliances, and the stern and self-denying character of its principal imparted to the school an air of austerity. Yet the life was not without spice. The rules were so strict that many an adventurous youngster proved his mettle by breaking them. The boys and girls, forbidden almost to look at one another, did sometimes fall in love. And there was the eternal charm of youth at its most impressionable period, hard at work.

"George Morris, candidate for this New Hampshire abode of the Muses, probably traversed the fifteen miles between Norwich and Meriden sitting beside his father, in the high, side-spring express wagon, drawn by Sukey, the staunch white Morgan mare. Loaded behind were his trunk and the necessary furniture of a school-boy's room, and, no doubt, a pail of Mother's doughnuts and cookies. On the road would be other wagons similarly loaded, and when they reached Meriden, the place would be lively with the horses and vehicles necessary to transport three hundred boys and girls. Apparently George conformed to the genius of the place, finding it very like what ruled in his own home, and received no challenge except to do his best in his studies. Dr. Richards taught Latin, and in both Latin and Greek the boy got the thorough start which made him excel as a classical scholar at college. . . .

"Just before his return to Meriden for his senior year, he united with the Norwich Congregational Church; "received into full membership," the records say; and we are led thereby to infer that the previous winter there had been a season of religious interest at Meriden. Perhaps some evangelist had been there, and there had been meetings either in the Congregational Church on the summit or at the Baptist Church at the foot of the hill, to which the students, under the stars in the snapping cold, over the glittering snow, had flocked in numbers. That George, at fifteen, should take the momentous stand, urged by the arts of the preacher, the prayers of his teachers, and the example of his fellow students, was very 
natural. He had been bred to it by his pious parents whom he loved, and he was temperamentally religious.

" He graduated in July, 1857, in a class which, as the Alumni Register implies, numbered fifty-four. Did all have leading parts? Did George, for his scholarship, have a leading part? Commencement Day at Meriden was second only in importance to Commencement Day at Dartmouth as a literary and social event in the region. People came from far and near as they come now on circus day, only they were of the nativeborn, and, for all their queer costumes and vehicles, had a nice taste for youthful oratory, and desired more of it than we do. The crowded green, the packed church, the platform, the dignitaries, the class, the speaking, the valedictory, the giving of diplomas, and the July heat,-George probably went through it all as other boys had done, and drove home with his belongings and his diploma, feeling as though the first milestone was passed."

A dozen themes, or essays in little, written by Morris for class debating societies or in the ordinary course of English instruction, survive from this period. They treat moral, social or political topics, and their titles, redolent of the atmosphere, are suggestive:- the Cultivation of the Mind; the Power of Habit; the Advantages of Early Rising; Description of a New Year's Eve; Contention benefits neither Party; Patriotism; Trust not Appearances; Are the conflicting Interests of the different Parties of the Republic compatible with the Preservation of the Republic? and so forth. While the MSS. show neat penmanship, correct, though stiff and sometimes archaic diction, and painstaking care,-there is not a single erasure,-they reveal the influences that played upon the boy rather than aught drawn from his own mind. The tone is distinctly pietistic, if not theological; constant are the appeals to God, conscience and duty. Webster, cited several times in the phrase, "according 
to Webster," is a final authority; and we are told, with similar naïreté, that one of the signal advantages of early rising is, that a man "will not be obliged to prolong his labour into hours when honest people are generally asleep." The moral, religious and social subjects are approached with ingenuous primness, but there is not the remotest trace of priggishness. The political exercises serve to tell that his father's doctrines had struck home. George thought that the Republic was bound to go to pieces, and,- -he adduces his reasons.

"But there is an aristocracy at the South consisting of the rich portion of the slave-holders, which controls, as it were, the whole movement of the wheels of government, disregarding laws and everything which oppose them. Now the existence of such a body cannot but be fatal to the existence of a Republican form of government and favourable to the establishment of an aristocratic one" (autumn of 1856).

New England had an easy way with slave-holders!

We still have the printed programme of the Senior Exhibition at Kimball Union, on 6th May, 1857. This must have been a tremendous orgy for the audience. No less than twenty-three senior boys, in the alphabetical order of their surnames, read 'orations.' Mercifully, the "young ladies," sixteen in number, had to rest content with the appearance of their names in the glory of print, and with the satisfaction of knowing that one of their fair band, Miss Emily S. Kent, of New Alstead, N. H., was the composer of the "Closing Song of the Class," sung at the end of this gigantic performance. Two of the addresses are worth record, on account of their authors:- "Administrative Example of the United States," by William J. Tucker, afterwards the distinguished President of Dartmouth College; and "The 
World in the Middle Ages," by Morris. The latter lies before me. Like the other, and much shorter essays, it is quite conventional. Rather blurred in its historical perspective ("the Middle Ages immediately succeed the advent of Christianity'), it takes a characteristically Protestant attitude,--quite unconsciously, for, of course, there $i s$ no other,- -and, in the compass of a brief five minutes reaches the beginning of the peroration.

"In this manner we behold God dethroned in the human heart and men placed in his stead ... preparing the way for that great moral Reformation which ultimately raised all Europe from subjection to priestly tyrants and impostors into the glorious knowledge of the Gospel of Christ."

It is quite plain that Morris received a sound training in direct preparation for college. In classics, in mathematics and in English, he had capital grounding. His instruction was admirable. But-education? It is equally plain that all the larger issues of life, the material for true education, continued in control of the norms derived from the New England home. The boy was not induced, probably not encouraged, to think. And the idea that religious, theological, moral, social and historical problems are susceptible of objective evidence did not so much as occur to him. Kimball Union helped him to assemble his tools, but how to use themthis lay altogether beyond its horizon. The intellect was kept in leading strings to moral and religious discipline. The feelings in which action finds its springs underwent no change, and the youth passed to college, judging as he had judged when he first left the family hearth. His Puritan culture stood its ground.

Morris entered Dartmouth College in the autumn of 1857. There were 249 undergraduates that year, and 
the Freshman class numbered 60, of whom, with the exception of Sidney Augustus Merriam, Morris was the youngest. President Nathan Lord was entering upon the final stage of his long administration of thirty-seven years (1828-63). Under his wise guidance, Dartmouth, its troubles past, laid the foundations of its success ever since.

"Might not President Lord, at the time of his resignation, have said without a shadow of boasting. . . I found it truly 'a small college'; it was in an humble condition; its classes were small; its finances embarrassed; its buildings in a dilapidated and ruinous condition. I left it one of the leading institutions of the land."*

But he had already published his two Letters to Ministers of the Gospel of all Denominations on Slavery (1854-5), in which he defended this institution on 'Biblical' grounds. These, and his attitude towards the Union later, during the Civil war, brought him into conflict with the Trustees of the College and with public opinion. He resigned in 1863 , protesting against the right of the Trustees

" To impose any religious, ethical, or political test upon any member of their own body or any member of the College Faculty, beyond what is recognized by the Charter of the institution, or express statutes or stipulations conformed to that instrument, however urged or suggested, directly or indirectly, by individuals or public bodies assuming to be as visitors of the college, or advisers of the Trustees. . . . The action of the Trustees virtually imposes such a test, inasmuch as it implicitly represents and censures me as having become injurious to the college, not on account of any official malfeasance or delinquency, ... but, for my opinions and publications on questions of Biblical ethics and interpretation, which are supposed by the Trustees to bear unfavourably

* The History of Dartmouth College, Baxter Perry Smith, p. 167. 
upon one branch of the policy pursued by the present administration of the government of the country" (July 24, 1863).*

The origin of this cause célèbre-for such it came to be in the New England of these days-was the only feature that disturbed the even tenor of academic life during Morris's course. And, as we have seen, the lad had been too firmly grounded in Abolitionist principles to be affected.

The matriculation requirements cannot have presented serious difficulty to Morris, who was an excellent classical scholar of the old literary type. They were thoroughly sound, comprising five books of Xenophon and three of Homer, together with grammar and prosody; the whole of Virgil, select Orations of Cicero, and Sallust, with grammar, prosody and prose composition; arithmetic, and algebra through equations of the first degree; English grammar, and ancient and modern geography. The academic year was divided into four terms, and the course of study prescribed. Freshmen took Greek, Latin and mathematics for three terms; physics, French and rhetoric for one term. Sophomores also took Greek, Latin and mathematics for three terms; French, philosophy and physics for one term. Juniors continued Greek and Latin for three terms, reading Demosthenes, and Plato's Phaedo or Gorgias, Cicero's De Officiis, Juvenal, and the Captivi of Plautus; three terms were now devoted to philosophy, also to rhetoric and physics; two terms to French, and one term to history. Seniors read philosophy in all four terms; rhetoric and physics in three; history in two; French and physiology in one. Public Examinations occurred twice a year, at the close

*Ibid., pp. 174-5. 
of the Autumn Term and, in summer, just before Commencement, Public Examiners being appointed to assist the Faculty.

In view of Morris's distinction later, it is interesting to notice the character of the philosophical and rhetorical instruction, so far as the textbooks afford indications. Sophomores began with Paley's Evidences and Campbell's Rhetoric. Juniors passed on to Whately's Logic, Butler's Ethical Discourses; Evidences of Christianity; and Whately's Rhetoric. Seniors attacked Reid's Intellectual Powers, Edwards On the Will, Schlegel's Dramatic Art and Literature, Say's Political Economy, Butler's Analogy, and The Federalist. Ere Morris reached these stages, Haven's Mental Philosophy had displaced Paley, and Trench's English Language had been added to the list.

No change of real importance disturbed the staff from 1857-61. The Class of ' 61 , too, held together well, more than 71 per cent. of the Freshmen appear on the Senior roll. In all essential respects, then, the College appears to have been singularly homogeneous-the 'Dartmouth style' was already a fact. And the question arises, What was the effect upon Morris? Thanks to the first-hand information supplied by President Tucker, his classmate at Kimball Union Academy and Dartmouth successively, a close friend moreover, and to the personal recollections of Mrs. Cone, I think we are compelled to reply, little, if any. That is to say, the nurture of the home remained paramount, nothing given by the College antagonized it. Dr. Tucker and Mrs. Cone agree very nearly in their judgments, which have been given quite independently.

Dr. Tucker's letter from Hanover, the seat of Dartmouth College, of date January 12th, 1912, is as follows: 
"You ask me as a class-mate of George S. Morris at Dartmouth, what there was in the college of his time to direct his mind toward philosophy. I think that the directive influences which set that way were at work back of the college. $\mathrm{He}$ had, to begin with, a remarkably truth-loving mind, and the quiet but sure courage to meet its demands. Then the family influences were strongly, though indirectly, at work to this end. His home was intelligently religious, and was dominated by the one great morality of the time-the antislavery sentiment. Had Morris gone into the ministry, as was proposed, I do not know whether he would have swung toward the ethical or the theological side. In either event, he would have put his truth-loving mind into action without fear of consequence.

"Professor Clement Long held the Chair of 'Intellectual Philosophy and Political Economy' while Morris was in college, and the text books in use in the department were Whately's 'Logic,' Reid on the Intellectual Powers, Edwards on the Will, Butler's 'Analogy,' and also, 'Ethical Discourses,' Say's 'Political Economy,' and 'The Federalist'-a pretty strong diet for a boy of twenty, and not in any way weakened by instructions from the chair. The stimulus from Professor Long was that of a perfectly lucid mind governed by inflexible logic. There were no evasions or mental excursions in his class room. What was the fact and, if outside the realm of natural things, what was the truth, was the question in many forms which a class had to face before him for an hour a day. Of a different type of mind, Professor Putnam, in the Chair of Greek, was equally stimulating, and perhaps responsible more than any other instructor for the fineness of Morris's scholarship.

"Owing to his residence at home during his college course, and also in part to his temperament, Morris did not share as much as some others in the give and take of college life. College did not call him out before his time. He was the first scholar in his class, but not a speaker; and yet I was not surprised, when some years later he spent a little time with me in New York on his way to and from Johns Hopkins for his first course of Lectures, to find that he threw away his 
preparation in manuscript, and spoke with entire confidence and self-possession out of the fulness of his subject.

"I would not attribute overmuch in the estimate of Professor Morris' mental training to his college course, but I am quite sure that it did nothing to deflect the natural straightforwardness of his mind, but made rather to confirm its original bent, and to urge it on its way toward the truth."

Mrs. Cone, on her part, comments thus:

"From his mother George is credited with inheriting his literary gifts. Susanna Weston's father had been educated as a lawyer, and was 'Squire' Weston at Randolph. Her brother Edmund was a college graduate and a lawyer. Her uncle Azel on her mother's side (Washburn), graduated at Dartmouth and was a minister, and her sister Lucy and cousin Lucia both married ministers. She herself had æsthetic and intellectual tastes to a marked degree, and was deeply religious. The Morrises, one generation after another, were farmers, tanners, and men of affairs, pioneers, selectmen, deacons. George was the first of them, certainly in the direct line, to go to college.

"During his college years George lived for the most part at home, walking twice daily the mile between Norwich and Hanover. Nathan Lord had long been President. It is said that 'probably the distinguishing marks of the Dartmouth type of man were received from him more than from any other source.' He was a strict disciplinarian, at a period when the discipline was largely personal, and he commanded respect and admiration. Testimony from outside the college says that he was an excellent judge of horses. His defection from the anti-slavery ranks placed him in opposition to the Trustees of the College and the Congregational Churches of the State. Sylvester Morris used to say that, inexplicable as the step seemed, it taught him charity, for he knew Dr. Lord for a good man.

"Of the professors, Clement Long, as professor of Intellectual Science and Political Economy, had much influence on his pupils, and great strength as an exact thinker. He was very tall and thin and had a high voice. 'You don't happen 
to remember what the author says on that point?' was a favourite method of address with him. Prof. Putnam taught Greek. He was a charming scholar, a very handsome man of a spiritual type, and possessed of a fine sense of humour. It is remembered of him that, on a Sunday evening, he excused himself from guests in order to go to prayer-meeting, saying that he must now go and 'suffer affliction with the people of God for a season.'

"George Morris was the youngest in his class save one (Merriam, b. 11 March, 1841), and its first scholar. While immature in some ways, he was not immature in mind, showing a capacity to adjust his mind to almost any requirement. An examination of the records shows a remarkable evenness of marks in all his studies, though he was a specially good Greek scholar.

"He was the first man in his class to be elected to the Psi Upsilon Fraternity. In ordinary affairs he was reticent, a quiet fellow. In recitation he was easy. Because of his living at home, he was at first little known, but when the class began to be aware of itself, his ability was recognised. During his senior year he had a room at the Observatory. As the end of the course drew near, the Faculty decreed that, with the Class of '61, the so-called Senior Vacation, of two weeks before Commencement, should cease. The class voted to observe the custom as usual, and cut to a man, all except George Morris, who attended every recitation-alone! The Faculty were amused at his quiet pluck, and did not discipline the class, and the class respected him. At Commencement, although his rank was undoubted, he was not given the part allotted to the best scholar. Daniel Noyes received the Valedictory. George Morris was Salutatorian. It has been remembered in the family that the class and the audience greeted him with marked applause, and when Noyes's turn came remained silent. The graduation occurred in July, 1861. George was twenty."

It is thus evident that Dartmouth, like Kimball Union Academy, effected no transformation of the fundamental judgments that constituted Morris's Welt- 
anschauung. The account given, by his later friend, Edward Caird, of Principal John Caird's undergraduate life at the University of Glasgow (1840-4) fits the case precisely.

"He had been brought up in a circle into which any idea of scepticism as to the doctrines of the Christian faith had hardly entered; and his philosophical studies, which were at that time mainly in writers like Reid and Stewart, while they exercised his powers, were not such as to affect his intellectual or moral life very deeply."**

Thanks to "the pretty strong diet for a boy of twenty," as Dr. Tucker calls it, Morris may have thought during these years, though along prescribed lines; he received no stimulus to rethink.

This inference is confirmed by exercises, essays and verses which have been preserved from Dartmouth days. Significantly enough, the earliest, read at the Theological Society, on 6th November, 1857, is a discussion of the text, "The serpent beguiled me, and I did eat." The lad evidently thinks that he has a historical incident before him-“an account of a temptation yielded to, which caused that a world before unknown to anything but holiness should become 'full of the abodes of wickedness.", The doctrine of human free-will is assumed, and the sequel proceeds to consider the Fall as the origin of the 'plan of salvation.' Mens immortalis: corpus mortale, of the same date, deals with the mind as "eternal in its destinies," quite theologically. Ideality versus Reality, written in the spring of 1858, enforces the need "of governing and chastening the fountains of the mind and imagination with a deep sense of moral and religious things." A theme, on Enthusiasm in the Student,

* The Fundamental Ideas of Christianity, John Caird, Vol. I, p. xiv. 
betrays an identical pietistic bent, and the same may be said of papers on subjects such as-Defective or Good Knowledge of Human Nature; Self-Denial as necessary to Success; and the Influence of Culture. A discussion of the Authority for observing the first day of the week as the Christian Sabbath is eminently characteristic in its utter innocence of historical evidence and method. "The sacred writer confirms, that God originally established the Sabbath as a perpetual ordinance." Four essays on literary subjects are extant, composed between June, 1859 and November, 1860:- a Criticism of "Prometheus Bound;" Irving's "Life of Washington;" Circumstances affecting the Character of different Literatures; and (once more significantly) The Moral Teaching of "Jane Eyre." The inwardness of Eschylus is not penetrated in the least. Irving's work is castigated for "the absence of virtues rather than for the presence of faults" and, most suggestive, reference is made to "the author's combined indolence and depravity"! The idea of immortality takes rank as the most potent circumstance affecting the character of different literatures. In the same way, Jane Eyre is held to "bear unmistakable marks of the comparatively low standard in morality and religion which is generally supposed to prevail in Great Britain. . . . . The work will be found to incline to an eclecticism in religion which is no less fatal to the universal spread of pure Christianity than it is removed from the express teachings of Scripture." Incredible as it may seem, this last represents the lad's point of view at the beginning of his senior year in college.

After the habit of youth, Morris perpetrated a mass of rhymes during this period. It is worth while, perhaps, to transcribe the following, not for its verse, but for its sentiment; it tells where his treasure still was laid up. 


\section{To a Vermont Village}

Emblem, thou, of peace and comfort, Proud prosperity in thee

Ne'er, with adamantine fetters, Binds the free!

Emblem, thou, of joy and beauty, $\mathrm{H}$ ard adversity in thee

Ne'er assaults the widowed mother

Of the free!

Ne'er in thee to hapless powder Is the cheerless orphan ground; Nor does louder still, and louder, Grow the sound

Of remorseless, sore privation Sending forth the bitter cry 'Hear, oh hear, my supplication Ere I die.'

Joy upon thy towering hill-tops, Gladness in thy smiling vale, Peace upon thy rolling river,

Tell a tale

Of contented, calm enjoyment, Love unsullied, hope undimmed, And the cup of man's rejoicing Overbrimmed.

Ever stand, in humble beauty, Symbolising to mankind All that's truly great and lovely, Brave and kind.

The Order of Exercises at Commencement, Dartmouth College, July 25, 1861, an eight-page pamphlet, is preserved. As at Kimball Union Academy, twenty-three 'orations' were delivered, Morris leading off on National 
Calamities Incentives to National Virtues.* Many notes for this address are extant. They witness that he took immense pains,- - as, indeed, he did with all his papers,and that the titanic struggle which, a few days before, had reached a culmination as unpalatable as unexpected, at Bull Run, was uppermost in his mind.

Conclusive as are the evidences already adduced for the unbroken sway of the Puritan conscience over Morris during school and college days, we are fortunate in possession of a document which throws vivid light upon his outlook and main interests. He began to keep a Private Journal during his Senior year at Kimball Union Academy. It dates from 13th December, 1856, to 22d August, 1861, and runs to 181 pages. One

* In his Private Journal, Morris gives a full account of the incidents consequent upon the failure of the Faculty to appoint him Valedictorian, notwithstanding that he was the best scholar in the Class. It seems that the professor, to whom his colleagues had delegated the arrangements, was responsible. The graduates were greatly incensed, not only by the slight put upon Morris, but by the fact that preference had been given to a son of a member of the Faculty-it was an obvious case of favouritism, they thought. Morris himself appears to have been most hurt by the explanation proffered by the author of the betise-it turned out to be untrue. In any event, when Morris appeared, the entire Class rose, and cheered lustily; when he ended, the same thing happened, and he was showered with bouquets thrown from the gallery. When the unfortunate Valedictorian came forward, the Class not only preserved silence, but some of them left the platform. Then, too, stimulated by the affront, Morris excelled himself. An alumnus of his acquaintance said, "You not only did better than I thought you should, but better than I supposed you could." And the offending professor, seeking Morris out, told him, "You never spoke half so well before in your life." The Boston Journal, of 26th July, 1857, in its full report of the Dartmouth Commencement, comments; "The best production was almost universally conceded to be that of George S. Morris, of Norwich, Vt." Morris concludes, "I write all this, not to feed my vanity, but as a true record of facts." We who teach must lay it to heart that the undergraduate has an alert conscience for fair play, and will take no denial. 
would naturally anticipate from a clever boy in a firstrate secondary school and, even more, from the most distinguished student of his time in college, many comments on study, and on problems arising from books read or views aired. Here, these are the exception, never the rule. Indeed, there is but a single long passage directed even to philosophical questions; we shall have an opportunity to consider it later. ${ }^{*}$ The few-less than half a dozen-direct references to study mention success casually, as it were, and proceed to give God the glory. In short, the Journal is redolent of an intense, often introspective, piety. Christianity of the most evangelical type colours everything. The sermon is the central point of interest. Records abound of attendance at church (always twice on "Sabbath"), at the school or college chapel, at prayer meetings, missionary conferences, fast days--in preparation for the "Lord's Supper"gatherings of the Christian Fraternity (at school) and of the Young Men's Christian Association (at college). Throughout, the vital things concern religion (theological usually) and morality. Study is all very well as a duty, but, at the best, no more than an instrument or training for "goodness." One might expect that this attitude would alter under contact with the larger sweep of college life. As a matter of fact, till the very end, pietistic outbursts recur-"God's spirit is not yet poured out in Hanover." The phrase, "the church of God," is taken as synonymous with the Congregational church! Traces of divine guidance- "God was very near to me to-night" - are acknowledged continually, and common events become texts for lengthy moralistic exordia, turning on "man as an accountable being."

* See below, p. 222 . 
The potent influence of the family circle appears in frequent references to immediate relatives, especially to "Mother, dear Mother," and to "sister" (Lucy). On the 27th July, 1857, Morris heard an address, by Daniel Kimball, of New York, before the Tilden Female Seminary. His record serves to confirm what Mrs. Cone has told us above about Lucy's character.

"He advanced sentiments with regard to the equality of the two sexes somewhat in advance of what his hearers, for the most part, were accustomed to hear. Yet I do not say that I disagree with him. He pleased my sister Lucy very much."

The pietas of the lad is so intense, touching and sincere, that I should deem it sacrilege to commit its expressions to cold print.

Naturally, this temperament moulds his views about things in general, as a few examples may suffice to show.

"Last Tuesday, I received a letter from my cousin, Lucy Washburn, from Tilden Female Seminary, in reply to one which I sent to her about two or three days before. When I wrote that letter, I was aware that there was unusual religious interest prevailing in the school which she attends. I dared, therefore, to address to her a few words of admonition and warning" (19th Apl.,1857). "Day before yesterday, I suppose James Buchanan was inaugurated President of the United States of America. May God grant him grace to do his duty much more faithfully then Frank Pierce has done!" (6th March, 1858).

Three years later (22d Apl., 1861) he writes:

"The unusual excitement relative to the affairs of the Country is quite unfavourable to any permanent religious impression, and calls for unusual efforts on the part of all, that nothing be considered superior in intrinsic importance to Religion."

So, too, moralism governs his literary judgments.

"This evening I heard John G. Saxe deliver his poem on 'love' in the College Church. It is a good thing. I 
enjoyed hearing it very much. It abounded in witticisms, but was not destitute of a large number of moral sentiments" (7th Oct., 1858). " "Read yesterday E. P. Whipple's Oration . . . . on 'Washington.' It is, of course, an able thing, and contains some valuable remarks on liberty" (3d Aug. 1859).

Even more striking and symptomatic is this:

"I have lately been reading-in part-the poems of John Keats. . . . There is something, either in their subjects or in their style, which is utterly offensive to my feelings. I think the fault lies partly in both quarters. His 'Hyperion' is called his masterpiece ... but did not disclose to me any crowning quality of genius" (19th Sept., 1859).

Inevitably, too, Bunyan wins upon him more than any of the other literary masters.

"I find him to be vastly superior to what I had commonly supposed. . . . Bunyan knew the heart of man, consequently interpreted the Bible correctly, felt the power of its truths, and spared no means, within proper bounds, to bring more to the knowledge of the truth" (20th Apl., 1860).

It is worthy of notice that references to his interest in music are frequent. He belongs to the Harmonic Society (really the school chapel choir); at the Kimball Union commencement, he takes the tenor part in a quartette; during vacations, at home, he "practices upon the piano," and teaches the Sabbath School children to sing hymns; he is one of the organizers of a singing school in connection with the Young Mens' Christian Association; it secures the services of a professional teacher, in whose absence Morris assumes the baton. Nevertheless, even music cannot be regarded as more than a handmaid.

"Upon the evening of July 7th, 1858, the Beethoven Society gave a concert. . . . When I came away my feelings were those of profound amazement. Art, as exhibited in the 
expression, and the grace of the performers and all their actions, together with natural talent, combined to produce music far exceeding anything of the kind which I have had the good fortune to listen to before. . . . I felt inward desires and aspirations for a like ability to sing in myself. Still I felt that the object I have in view-that of being educated and doing good-is perhaps a far better and nobler one."

We learn, too, that Morris pursued a wide range of reading, outside class requirements, especially during his Senior year at Dartmouth.

"I am now reading and studying Mansel's 'Limits of Religious Thought' by myself."

Pardoe's "Louis XIV”; Robertson's "Scotland"; Cooper's "The Deerslayer"; "Kenilworth"; "Oliver Twist”; De Quincy's "Miscellaneous Essays" (Lamb, Coleridge, etc.); "Emerson, E. P. Whipple, with a touch of Carlyle," are specified. Miss Muloch's "Poems" please him, and he "has read a great deal of the Bible." "Have just finished Prescott's 'Ferdinand and Isabella,' the first history that he wrote. I have been considerably interested in it, though it is by no means so engaging as his 'Philip the Second,' which is superior to F. and I. in execution and finish, as well as in the natural interest that belongs to its material” (22d Jan., 1861).

"During Senior Year I have read a great deal-much more than I have mentioned in my Journal-particularly Motley's History" (22d Aug., 1861).

Would that the gilded youth among our contemporary Seniors, who are so apt in twelfth-hour sciolisms, might follow this example, to the soundness of their mental health!

The Journal also reveals that his education was not altogether literary, and that, during his Junior and 
Senior years, he lived in college, away from home. He pursued courses in Surveying with such success that, when students were divided into squads for outdoor work, he was chosen a squad-leader. The best rooms in college were two at the Shattuck Observatory (then one of thefew well-equipped observatories in the country)* They were assigned by appointment to the first scholars in the Junior and Senior classes respectively. During his two years' residence, Morris learned something of astronomy, and he records:

"For the last two or three evenings the members of my Class have been coming up here in bodies to look at two or three of the major planets, Saturn, Jupiter or Venus. This is at the suggestion of Prof. Patterson, and it is my duty, of course, to wait upon the boys, and give them such information as I may be able to."

Finally, it is worthy of note, as bearing upon his future career, that he had several opportunities to teach, from his Senior year in school and on. In February, 1857, when Principal Richards was absent, Morris heard the Latin classes at Kimball Union Academy-a tribute, too, to his scholarship. In January, 1859, he tells us that, during the long vacation between terms, he taught four hours a day in Mr. Pease's private school at Norwich. When a college Junior, he acted as classical tutor to a brother of Professor Patterson (mathematics and astronomy) - a teacher who, by the way, exerted considerable influence over him. In December, January and February, 1860-61, he taught for twelve weeks in the school

* We still possess his careful description of the equipment, with an account of its cost, and a comparison with the resources of the observatories at Washington, West Point, Cincinnati, Hamilton College, and Albany, N. Y. 
of District No. 3, Medbury, Massachusetts. We need not wonder, then, when we light upon this, the last, entry in the Journal:

"Next week I go to Royalton with sister Lucy, to take charge of an Academy" (22d Aug., 1861). 


\section{CHAPTER III}

\section{Early Manhood. Royalton. The Civil War. Dartuouth College once More}

(1861-64)

Royalton Academy, whither Morris went so happily as principal, with his favorite sister to assist him, had been founded in 1807. Royalton township, which lies some twenty-five miles northwest from Windsor, the county seat, had a population of 1739 in 1860, and the village appeared to Dr. Gardner Cox, now of Holyoke, Mass., who came down to the Academy from a hill farm at Barnard (in 1861), "a big city, compared to its present utter loneliness, when there are none so poor as to do it service."* Indeed, it ranked with Windsor, Woodstock and Norwich, as one of the important places in the county. By good luck, we still have the prospectus of the Academy and the report of the Committee

* Mr. Mason S. Stone, Superintendent of Education for the State of Vermont, has been good enough to give me the following information relative to Royalton Academy. It confirms Dr. Cox's statement. "The town of Royalton has greatly decreased in population. The village of South Royalton, two miles below Royalton, has increased in population and greatly overshadowed the old village of Royalton. Until this year (1913), S. Royalton was an incorporated school district. The old Royalton Academy had been run by the town as a high school but, with the decrease of population, the attendance upon the Royalton High School had decreased to less than twenty. Therefore, this year (1913), the S. Royalton Incorporated District surrendered its articles of Incorporation, went into the town, and the South Royalton High School became the high school of the town and the old Royalton Academy ceased to exist. Its transition from an Academy to a High School was made in 1908." 
of Examination for 1861-2. As principal, Morris had supervision of classics and mathematics and, when necessary, taught German and music. His sister was preceptress and gave instruction in French. Miss Alice Denison taught drawing and painting. She was a member of the old Royalton family which, later, furnished Morris with a colleague at Ann Arbor, in the person of Professor Charles Simeon Denison (d. 1913). Denison appears as one of the speakers at the academy "Exhibition" of November, 1861, and was therefore a pupil under Morris. Mr. J. E. Emery was assistant to theyoung principal. The'Examiners commend the school for its thoroughness and accuracy as follows:

"Not only the strictness with which the Latin and Greek languages are here taught, is worthy of approbation, but, also, the extent to which the study is carried: so that recitations in Xenophon and Homer, by young ladies as well as young gentlemen, appeared as favourably as would be expected under skillful training in any seminary of learning. The range of study, heretofore extensive, has been enlarged by the addition of a class in Astronomy, such as does not often appear in schools of this description."

The attendance numbered one hundred. As we shall see later, ${ }^{*}$ the youthful head exerted instant influence. Not in their studies alone, but in religious life and social decorum, the pupils found a leader upon whom they could set their trust. The new circumstances produced no change in the temper of the man. The pietistic tone still prevails, supported, undoubtedly, by all the surroundings. Morris enters upon his task, "resolved to live nearer to Christ" - a resolution written down on his birthday, 15th November, 1861.

* See below, p. 72. 
Six lectures-five addressed to his pupils, one to a maturer audience at East Barnard-remain, to indicate his mental attitude at the time. The school addresses are on the Objects and Methods of Study; Geology; Elements of Perfect Manhood and the Present National Necessity for Real Men; Books and Reading; a general review of the subject for the class in the History of England. The public lecture is on Astronomy. Once more, the notes already familiar to us are struck.

"Intellectual and spiritual nature is to be managed and directed by us to the greatest individual development, for the highest good of the race, for the glory of God and our final well-being."

Geology serves to enforce the argument from design. The voice of the Puritan North rings out clear:

"Our own country is now in a condition that requires the definite development of individual and National character. The wild forces of evil have formed an insensate union in opposition to the ideas of law, civilization and progress. They summon us to a contest in which force, brutality, barbarism and retrogression are arrayed against liberty, order and improvement" (7th Nov., 1861).

The austerity necessary in reading is set forth:

"There is little danger that many of you will become too deeply read in the appropriate kind of literature here. This is partly due to the too prevalent notion that reading is a mere pastime, and no work. It is, indeed, work. The more it taxes the mental powers, the more substantial and, under certain conditions, the more useful it is. One requires at the outset the same determination, only of a higher kind, in order to accomplish much in the way of profitable reading, which is needed when one undertakes a piece of manual labour."

The history of England is dealt with according to a sanctified common sense. As for Astronomy, 
"It is regarded as historically certain, that astronomical observations were made, with considerable success at least, soon after the fall of the tower of Babel. . . . The visible universe constitutes a standing argument to demonstrate the glory and power of the Creator. A correct appreciation of its vastness and undisturbed order, together with its marks of exquisite design, strengthens in the mind the belief in the Deity. As this sentiment gains ground, the sense of obligation increases. The sum of personal consequence is diminished. The feeling of subjection to the control of an Infinite Power is increased. Man reaches Jehovah in forms of beauty and love and might, as night approaches."

In a word, while the material is always excellent, and the presentation clear, occasionally elegant, the general outlook remains true to the teaching of the New England home. Moreover, in these, as in the earlier MSS. which survive, humour is conspicuous by its total absence. The weight of human life, discernible everywhere, does not depress, warm faith sustaining; but grave seriousness grips the young principal, who has just attained his majority.

Nevertheless, his open mind, responsive to new duties and to contemporary events, asserted itself. Politics, history and science pressed their claims to consideration successfully; the excitement of the times did not keep him from books, and we know what he read. On the back of an old letter, the following notes are pencilled: "Books read in 1862. Ashley, "Common Sense"; Baldwin, "The Want of the South"; Cheney, "Scientific Farming"; Denison, "Political Criticism of Public Men"; Maxham, "Mineralogical Wonders of Nature"; Mosher, "Origin and Development of Polytheism among the Classical Nations"; Parker, "Future of Canada"; Parkhurst, "Selfishness versus Self-Respect;" Phelps, 
"Wars of the United States;" Smith, "Uses of History." And so, thanks to many preoccupations, the year at Royalton passes quickly, to end in a selfexamination, covering but a sheet of note-paper, yet a document full of intimation.

"I am about to leave Royalton. I have been Preceptor in Royalton Academy one year.

"I have failed during my stay here in the following respects. (1) In labours for the spiritual welfare of my pupils. I might have been a better Christian, thus setting a better example, if I had been actuated in my Christian exercises and acts less by fear and more by love to Christ. I might actually have led some of my scholars to Christ, if I had laboured expressly for this purpose, subject, of course, to the decisions of an all-wise Providence. (2) In my intercourse with my scholars I have not, in many cases, exhibited that force of character which I should have desired; nor have I led their minds to the proper objects of thought and desire, to the same extent to which I should like to have done it. (3) I have not taught as energetically, faithfully and conscientiously as it would have been well to do.

"On the other hand, I have endeavoured (1) weakly to lead my pupils to a correct and thorough knowledge of all their branches of study. I have the satisfaction of knowing that I have been partly successful. (2) I have tried, by precept both orally and by lectures, to set before them right motives for study, and right objects of ambition, and to incite them to enthusiasm and studiousness in many subjects more or less connected with their studies. (3) I have sought, more or less, to be genial and pleasant in my intercourse with my scholars, to assure them of my personal interest in them, and, by my conduct, to secure their respect. (4) In the conduct of the daily religious exercises, I have to some extent sought to render it impressive, and trust that some impressions have been communicated thus, which will be permanent and useful.

"I have been treated cordially and with great respect by scholars and citizens. I leave because I cannot, consistently with my plans and desires, remain. I have no time to throw away. 
"Here I cannot make much money. What time I do teach, I must make it profitable, that I may earn money to bear further educational expenses, and to assist me in the prosecution of certain designs of travel and study, which I shall be very much disappointed not to carry out.

"I go to Auburn Theological Seminary, God willing, next autumn."

This confession establishes several points. First, Morris's faith and fundamental attitude towards life are entirely undisturbed as yet, although he nears his twenty-second birthday. Second, he regards teaching as no more than a method to furnish the financial means for a farther end. Third, he still proposes, as when he entered Kimball Union Academy, eight years before, to find his vocation in the Christian ministry.

At the same time, one quality should be recalled, for it was destined to assert itself afterwards. Dr. Tucker tells us that, from the outset, Morris "had a remarkably truth-loving mind, and the quiet but sure courage to meet its demands." Now, the Royalton addresses offer many signs that his orthodoxy, as we may call it fairly, was not based on blind attachment to the letter of Scripture. He never "thanked God for being able to confine his attention to the one Book." Rather, he brooded upon 'the things which cannot be shaken,' and his musings were directed by a consciousness that the system of Christianity-identical with the system of truth-contained something distinctive and, particularly, something universal, from which all human affairs derived their real significance. 'Surrounded by so great a cloud of witnesses,' man was suffused with a glorious nimbus. The idea that

"The horseman serves the horse,

The neatherd serves the neat, 
The merchant serves the purse,

The eater serves his meat;

'Tis the day of the chattel,

Web to weave, and corn to grind;

Things are in the saddle,

And ride mankind,"

would have appeared infantile to him. But it had never occurred to him to ask, Why?

"The sudden element that changes things,

That sets the undreamed-of rapture at his hand,"

was still to be tested. He was the subject of definite coercive principles, in no sense their master. Besides, practical affairs were to interpose, so that two years elapsed,-years of new horizons,-ere he could realize his cherished project of farther preparation for the ministry.

Like all New England, Royalton was in a state of excitement when Morris arrived. Dr. Gardner Cox writes:

"It was war times, drums were beating and war's wild bugle blasts were blowing. The soldiers were camping in the old town house on the common, as they organised a company in Royalton, and from the surroundings, one hundred strong. ... . It was a great day for Royalton, with one hundred students and one hundred soldiers drilling. Morris was much interested in the soldiers, and made several speeches, talks to the people, on the spur of the moment. I well remember one afternoon, when every father and mother was there, and the train was about to move out, carrying those who were never to return. The second lieutenant of the Company was Daniel Lillie, later Captain of Co. 1, 4th Vermont Regiment, wounded in the battle of the Wilderness, and died in Washington, after an operation by Surgeon Bliss, who attended President Garfield. . . . Several of Morris's students became quite celebrated." 
Human emotion could scarce resist such appeals. But Morris, schooled to detect the futility of mere feeling, was revolving the situation reflectively, forming reasoned convictions. He says:

"I make the following extract from a letter written by me, August 18th, 1862, as a deliberate record of my convictions at that date:-I am planning to enter Auburn, N. Y., Theological Seminary this fall, unless I am drafted into the military service of the United States.

"I have by no means been insensible to the claims which our Government justly lays to the active service of all able-bodied young men throughout the loyal country. I take the course indicated above in face of strong impulses. I have many times been strongly moved to yield to my, as $I$ think, purely patriotic instincts, and join the Volunteer Army in some capacity. To be a soldier in the Union Army at the present time is, in my opinion, a truly honorable and glorious service- sufficiently so for any mortal and, in case of extreme national peril, of paramount importance as a duty. Yet, there is another service still, superior to this in glory and honour-that of Christ in the sacred Ministry.

"To this, my desires, with increasing ardour, lead me, and, for this, my education has already partly fitted me. Unless, therefore, the necessities into which rebellion forces the Nation become so pressing as to require every man to spring to the rescue by volunteering, I incline to think it my duty to proceed, so far as my health will permit, with the work of preparing for the clerical office, until I am brought into the Army by a draft, in which case my duty will be plain, since 'the lot is cast into the lap, but the whole disproving thereof is of the Lord."'

The New England conscience never spoke more forthright. Nor were the larger issues of principle neglected. Morris had made up his mind about the 'cause' no less than about possible practical events. We still have a paper on Slarery - perhaps an address on such an occasion as Dr. Cox mentions-that speaks with no uncertain sound. It bears the date 4th September, 1862 . 
"Slavery is a relic of harbarism. Violating the most obvious and sacred principles of right, it is utterly repugnant to an uncorrupted moral sense. Ministering, as it does, to some of the most violent passions of man-his avarice and love of power-it easily blinds those who are selfishly interested in its existence and perpetuation. . . . If Slavery should continue, the demands actually made by the Rebellion, which represents the interests of Slavery, are such that even the temporary preservation of the Union, and of Peace, is impossible, without an entire subversion of the spirit of our Institutions. . . . The genius of Republicanism requires for its proper development a high state of moral enlightenment. So far as a people are deficient in this respect, their institutions, if Republican, are unstable-if monarchical, they may be perpetuated, for monarchism savours of barbarism. ... . Now, the extravagance and insolence of the Slave Power have culminated in direct attack upon the Government. The success of this attempt would involve evil consequences of untold magnitude. To foil this unholy attempt, the Nation springs to arms, unanimous in devotion to the Republic-still divided in sentiment as regards Slavery. But this disagreement in opinion fast disappears with the continuance of the war. And the more sensible the nation becomes of the deadliness of those thrusts which Rebellion for Slavery is making upon the best interests of the Country, the less sensitive will it be as to the extremity of means resorted to to parry them. . . . I now believe that God designs this War should not terminate except with Slavery. . . . I believe we shall be allowed only partial success, until after emancipation has been proclaimed, and measures have been taken for its actualisation. Reverses are the discipline by which we are to be educated to the unanimous adoption of this sentiment. The cost of this education is great, but we must endure it. May God hasten it in his own good time! . . . Plainly, the hand of God is seen in the election of Mr. Lincoln and in the history of our country since his entrance upon the duties of his office."

Here, again, we find Morris joyfully submissive to a coercive principle. Right is not Right in itself, but on the indisputable ground that God commands it. The individual man is not his own, but is bought with a 
price,- - the ideal inspiration of his folk, likewise divinely bestowed. Patriotism rules, because devoted to the sole ends that can be accounted worth while. Thus, when the inevitable came, and Morris enlisted, he was not the subject of gusty emotion, of impracticable loyalty. His great resolution must be postponed in favour of a greater, one no less an ordinance of the Almighty. It was the old, old story, the tale of every masterful human achievement, "Speak to the children of Israel, that they go forward." An Ultimate Power winnowed reality from immediate appearances. This was manifest even to a raw youth, without any sort of large perspective, as Dr. Cox confesses himself.

"You can say on my authority that, if there was ever a soldier who enlisted from pure patriotism, it was Morris. My first talk with him, after we met in the army, was at Brattleboro, our first place of rendezvous. I was saying, that I was astonished to see him in the company and in the ranks. And he said: 'It is my duty, every loyal man owes his service to the country; I know it is a great sacrifice to break into my plans, and give this time to the country. But I could not stay at home and feel that the country needed my services. I could not sleep and feel that I withheld from the country that which I had to give in this supreme hour.' He was visibly affected, tears ran down his cheeks, but he repeated it over and over again, that whatever he had to give, it did not belong to him to keep. I will say that Morris had not a taint of military instinct. He handled his gun as awkwardly as a woman does an axe and, when he marched, it was out of gear with the rank and file. . . . When I got into the war, in the 16th Vermont Regiment, I was dumfounded to find him there, and only a private, while I, a poor country lout, was an officer. The Colonel, Wheelock G. Veazey, was also a Dartmouth graduate, and, when he found that Morris had enlisted purely out of patriotism and duty, he made him postmaster to the regiment, which kept him off the firing line, and gave him a tent all by himself. Once a day he 
went after the mail bag, sorted out the different Companies' mail, and handed it out to the orderly sergeants, of whom I was one for the first months. He peddled postage stamps and, I believe, had paper and envelopes for sale. . . . We were all so glad that he had that place-there were several of his Royalton students in our company. We felt proud of him, even if he did not have a shoulder-strap on his coat."

And, although Morris had no flair for soldiering, they had reason to be proud. Dr. Cox continues:

"As I was an orderly sergeant, I had the privilege of keeping a light burning in my humble tent after all the rest were out. Morris, ever true to his impulses, came into my little tent, where lived four others. He had five copies of Hamlet, little, cheap, paper-covered Hamlets, but Shakespeare's own Hamlet. $\mathrm{He}$ said to one Bowman, who belonged to another tent, but who was a fine scholar with me at Royalton, 'now scholars, I want to introduce you to the best intellectual entertainment in all literature,' and he gave us each a copy. I never had read a word of Shakespeare, and did not suppose ordinary mortals could understand, and I was shocked that he should think that we country chumps could read Shakespeare and understand it. .... We were made to love those evenings with the greatest profit and enthusiasm. Each read a part assigned to him and, in the course of a few months, we had pretty well studied Shakespeare, and had gone over all of the best plays. It whiled away so many of those long, weary, lonesome nights to us poor homesick boys, scarcely acquainted with the world enough to speak for ourselves."

We still have a short paper on Shakespeare, dated at Fairfax Station, Va., and undoubtedly read to the 'boys' by Morris. It serves to indicate that his moralistic approach to art had not altered a whit.

"The drama is not the product of modern invention. Among what people it was first known in its most rudimentary character, I cannot say. Quite likely something answering to it may have sprung up spontaneously in many nations, no one borrowing 
from another. For since, like all national amusements, and all national customs, it must owe its origin to the existence of some normal and virtuous, or unnatural and vicious want of humanity, and since humanity, the world over, is essentially the same, the same want or desire would not improbably lead to the same concrete result in different places, at the same time. The drama has its original warrant in a real and therefore sacred want of human nature - the want of an actual, perceptible, and comprehensive representation (necessarily a representation of human life) by which individual life should be dignified and elevated, something that would stimulate self-penetration and selfknowledge, and that, by stimulating thought, deepening feeling and imparting knowledge on one's higher capacities, should serve to educate the man. To educate, I mean, in the highest sense. . . The drama, then, not only existed at an early date, but had a right to exist, since it was adapted to satisfy a longing and a need of man. . . . Another form of the Drama afterwards arose, called Comedy, of which Aristophanes is the best exponent. In this, living individuals were ridiculed, fun was made of everything. The stage had degenerated when men employed it, not merely for exciting merriment, an object sufficiently laudable in itself, but to traduce public men, make light of the most serious realities of life, and corrupt the manners and morals of the people, by representing immorality and indecency as virtuous. Shakespeare's Plays are chiefly tragedies, a few of them are comedies. His age was rich in dramatic writers. The stage was then countenanced by the most virtuous, and tended to the improvement of the people. If, at the present day, the theatre is, not merely in the public mind, but actually, associated with dens of drunkenness and licentiousness, we should beware of condemning the good from its unfortunate and unnecessary connection with the evil."

The circumstances which led Morris to enlist are quite clear. Aroused by the disasters of the Peninsular campaign, President Lincoln issued a call for 300,000 militia, to serve nine months. This was on 4th August, 1862. Vermont's quota was 4898 men. On 15th 
August, Governor Holbrook, of Vermont, issued General Order, No. 13, wherein he appealed to patriotism.

"The order stated that no recruiting officers would be appointed, but that the town officers and patriotic citizens would be expected to enlist the men and form the companies. . . . Among the men so enlisting were many men of high patriotic purpose, whose professional and civil responsibilities had not permitted them to engage in a three years' term in the army."**

The Second Vermont Brigade, consisting of the 12th, 13th, 14th, 15th and 16th Regiments, was formed in answer to this call. Morris enlisted in the 16th. The Regiment had its rendezvous at Brattleboro, on October 9 th, where it received its accoutrement, and learned the elements of discipline. It was mustered into the service of the United States on the 23d, and, moving south immediately, reached Washington on the 27 th, to find the 12 th already in camp. $\dagger$

* Vermont in the Civil War. A History of the Part taken by the Vermont Soldiers and Sailors in the Warfare for the Union, 1861-5. G. G. Benedict. Vol. II., pp. 399, 401. Chap. xxvi., Vol. II., contains an account of the Second Brigade.

$\dagger$ The following outline of its service is condensed from Benedict, Chap. xxvi., Vol. II. On 28th October, 1862, just as it was settling down in camp at Washington, it was ordered across the Potomac, and went to "Camp Vermont," near Centreville, Va., where it did picket duty on the defence line of Washington, and fatigue duty on the works of Fort Lyon. In mid-December, when Sigel's corps left Fairfax Court House to support Burnside, the Vermont Brigade took its place, picketing the outer defence line of Washington along Bull Run and Cub Run. In the midst of Mosby's raids, which began at the end of December, and culminated in the capture of the Vermont Brigadier, General Stoughton, on the night of 8 th-9th March, 1863, the 16th moved to Fairfax Station (19th January). Here it remained till the end of March, when it moved forward to Union Mills, doing picket duty from Bull Run to Blackburn's Ford, and guarding the reconstruction of the railway from Orange to Alexandria. On 25th June, the Brigade began its march from Union Mills to Gettysburg, and covered 120 miles in six days, undergoing many hardships. It arrived at Cemetery Ridge during the 
Morris, who rose to the rank of corporal, was a member of Company K (Chester), which enlisted on 15th September. Thirty of its one hundred men came from Norwich, among them the captain, Samuel Hutchinson. Another corporal was Charles B. Converse, a distant cousin of Morris. As we have heard already, the colonel was Wheelock G. Veazey (Dartmouth, class of 1859, afterwards a Justice of the Vermont Supreme Court). His Roster contains this record: "A more intelligent and educated body of men, it is safe to say, was never mustered for any regiment." Morris was successively mail carrier for the regiment, and Assistant Brigade Postmaster. Referring to the latter office, in his single letter from the seat of war now preserved, he writes: 'I am very glad of the place, especially as I did not ask for it. The retiring Asst. P. M. belongs to the 12th Regiment. Henceforth I shall pass every other night at a public house in Alexandria, Va. Of course, I have

night after the first day's battle, and came into action on the afternoon of the second day, when Humphreys' line was nearly pierced. An awful night of picket duty among the dead, dying and wounded followed. On the third day, the $16 \mathrm{th}$, with the $13 \mathrm{th}$, executed under the orders of their Brigadier, Stannard, the famous flank movement which resulted in the repulse of Pickett's division. The 16 th had taken numerous prisoners and was scattered in groups looking after them, when Wilcox came up. Veazey, reforming his men, repulsed this attack, which had been delivered too late to be of any avail. The 16th lost sixteen killed, eighty-five wounded, and thirteen missing. On the 8th July it had reached Middletown, Md. On the 13th, near Hagerstown, it saw its last fighting. On the 18 th, the Brigade left the Army of the Potomac and, going by way of Berlin and Baltimore, reached New York on the 20th. Although not asked for assistance against the Draft rioters, the presence of the regiments over-awed the mob. On the $24 \mathrm{th}$, the 16 th went to Brattleboro via New Haven, where it was mustered out of the service of the United States on August 10th. Its high morale is attested by the fact that, despite continuous hardships, only three men deserted from its ranks. 
nothing more to do with a gun." Internal evidencea reference to Mosby's famous raid-enables us to date this letter 11th March, 1863.

Although "detailed on detached service" by his postal duties, Morris undoubtedly learned much from his military experience. The 'sheltered life,' under the eaves of a peculiarly rigid home, gave place to new contacts, and to strange exhibitions of the possibilities of human nature. Thus his cousin, writing on 4th November, 1862, from Dartmouth College, to congratulate him on his post office appointment, says:

"My reference to the Company leads me to speak of a fact of which I am assured, and which it will not be improper for you to know, viz., that you have gained to a degree unexpected by them, the confidence and esteem of all its members. Most of them, having a petty prejudice against a man who has 'been to college,' did not expect to like you. And it gives me much pleasure to know that they have been happily disappointed."

Morris enlisted against the better judgment of his parents and immediate friends, who thought him too rare stuff to be given as food for powder, and feared the contaminating influences of the camp. Nor were they left without reason for their qualms, as his letters arrived. His mother, writing on 4th March, 1863, expresses herself most forcibly and characteristically, evidently with reference to previous correspondence.

"Your letter to father was a good comforting one to us. I presume you will never indulge in such 'trifling' again. I was so perfectly astounded to hear from your own pen (any other person's I should have disbelieved) that you received 'whisky rations.' I do hope there are not many who indulge in 'taking a drop.' . . . I should like to know why the government permits that curse among our young men who have entered its service; it will be to many, I fear, a worse enemy than thousands of Southern rebels, for they can only kill the body, while drunken- 
ness destroys both body and soul in hell. . . . I fear that there is some such 'Achan' in the camp-the reason that God does not grant us greater victories over our enemies."

It is fair to say that his sister, Susan, interposed with a letter, in which she deprecated the tremendous 'wiggings' administered by the old folks, who did not realize the rigours of that late winter in Virginia.

Once more, his sister, Lucy, with her accustomed penetration, saw that "the camp" could hardly preserve intact the moral austerities of the New England home. Writing on 24th March, 1863, she says:

"I can discover by your letters how you are developing, how your character is growing by change. You are just beginning to realize the mystery of yourself, and getting the key which makes the apparent opposites one and complete. . . . It is one of the most difficult things for a person of almost purely literary and intellectual tastes, to estimate duly the practical side of life. Yet it is essential to a comprehensive manhood. The experience you are having this year will be of value to you. How much you are gaining in knowledge of the world and yourself! Probably this and the next two years are to be the most important of your life, as you are beginning to know your powers and how to use them. Hitherto you have been occupied in receiving, hereafter you are to dispense-with such ability and resources as you have."

Miss Morris saw even better than she knew-three years later her brother was in Europe, and had to all intents and purposes renounced a career in the Christian ministry. Well had she earned the right to exclaim,

"I think of you most Sunday evenings-and, sometimes, I feel as if the intensity of my wish to talk with you, must form a sort of Telegraph between us."

Morris never repented his enlistment. His aunt takes the point admirably, writing to him the week after Gettysburg: 
"But if you live to return, to live in peaceful times, what a history you will have of your own!"

His sister likewise perceived the benefits that balanced against the sacrifices:

"I congratulate you upon your patriotism. Its effect upon yourself must be wholesome. Mr. Charles Dana wishes more of the army might feel as you do."

His brother expresses himself to the same effect, although with puritanical reservations:

"I judge by your letter that you are not sorry that you enlisted. I am glad it is so. I think the motive which induced you to go will sustain you through the Campaign. I often wonder if you will come back to us as gentle and refined as you went out from us. I have a great horror of camp life and its influences. Do the men seem to have any regard for the Sabbath? are they easily approached upon religious subjects?"

Morris certainly learned that, important as this outlook is, there are others. The hard knocks of campaigning left their mark, just as his sister detected. Affection had sharpened her wits. The shy student faced the sterner realities of life, and was forced to 'give and take' with other men. Nevertheless, his fundamental standpoint had received no shocks as yet. Inspired by the family idealism, and by intense Abolitionist principles, he had made a great sacrifice for duty. But it had been a deliberate sacrifice, and the duty, with its religious or theological background, held him fast in the old ways.

Accordingly, in June, 1863, we find him corresponding about the merits of several Theological Seminaries with the Rev. S. W. Boardman, who had been minister of the Congregational church at Norwich during the Kimball Union Academy period. Mr. Boardman, then resident in Auburn, N. Y., naturally favored the local institution. 
Moreover, he secured for Morris the refusal of the most valuable scholarship in the gift of Auburn Seminary$\$ 170$ per annum for three years. He admitted that Andover was "the most scholarly in its course," but held that "Auburn is most free from crotchets, and is eminent for elevating the word of God." We find him also adverting to Union Theological Seminary, New York, and saying, "It seems to me that a course here would be better than at New York." True to his musical interests, Morris had inquired about an organ, only to be told, "I do not see any immediate prospect of one." While Morris was a boy, he had formed a great admiration for Boardman, to whom he often refers in his Private Journal, and recurring, no doubt, to some expression of this, his correspondent adds:

"You seem to value my society too highly; it could be of no advantage to you except from kind feeling, and the gratification of friendly intercourse. Count it as nothing in the decision, but if you come I shall be delighted to have it so."

Mainly for financial reasons, Morris was to make no decision on his return home. He joined the staff of his alma mater, as Tutor in Greek and Mathematics, and spent the academic year $1863-4$ in residence at Hanover, N. H.

After the lapse of fifty years, and owing to the fact that correspondence with his family was unnecessary, few intimate details concerning his service as Tutor can be recovered. He taught Greek and mathematics to the Sophomore and Freshman Classes. No events of moment seem to have marked the college year. As at Royalton, and in the army, he was a man greatly beloved. The qualities which so won upon his colleagues and pupils later were in evidence already, as the following 
letter attests. It is from a Sophomore of 1863-4, now the distinguished former Chief Justice of Samoa (under joint appointment of Great Britain, Germany and the United States), Governor General of the Philippine Islands, and Minister to Spain, Judge Henry Clay Ide, of St. Johnsbury, Vt.

"Fifty years is a long vista across which to call up the portrait of one whom I knew only as my instructor in mathematics and Greek for one college year at Dartmouth. Yet I can see him fairly well, a slender young man, of light complexion, with a scholarly, thoughtful face, and quiet gentlemanly manners, courteous to all the young students who had the benefit of his thorough scholarship, and zealous to be of real assistance to all who came under his instruction. Such is the picture of George Sylvester Morris, as I call it up from its dusty recess in my brain.

"I knew him only in the class room. Here he was kindly, sympathetic, helpful, an excellent instructor, and manifestly an accomplished scholar whom all his pupils respected, although the full professors, older and more experienced men, inspired us with more awe. Personal intimacies between students and members of the college Faculty were unusual, and a student who attained such intimacy was looked upon by his classmates either with envy or suspicion, and was called 'a faculty dog,' and to him was attributed all information which the faculty might obtain as to the real culprits in college deviltry. For this reason, among others, I did not have that personal acquaintance with Tutor Morris, which undoubtedly might have given me much pleasure and benefit; but I know that he appreciated me personally for all I was worth, probably more, and that of course attracted me to him.

"I remember that on one occasion in the autumn of 1863, when I was a sophomore, he sent me to the blackboard to work out some problem in the calculus, and I covered the board with figures without reaching the solution, but could see it some distance ahead. I asked for a table of logarithms, which he gave me, and then the result came all right, but by a very round-about process. He said that was entirely correct, but proceeded to show me a shorter way 
to do the work. He, however, must have marked me perfect on that occasion, because my standing in mathematics for that whole term came out marked perfect. I knew at the time that he was afraid I was going to break my record, and seemed as anxious as I was. The satisfaction that plainly showed itself on his face when I finally landed on the goal, through a tedious but strictly logical mathematical method, told me that he was on my side in my tussle with that particular proposition, and not, like some instructors, eager to catch one tripping. So there was always a silent bond of sympathy between him and me as long as he remained connected with the college.

"I never saw him after 1864. But I am very glad to have an opportunity to give these slight reminiscences of the impressions made upon my youthful mind by the scholarly and earnest young man-not so many years older than myself-whom we all respected and admired as 'Tutor' Morris."

Professor Horace Goodhue, of Northfield, Minnesota, a member of the Freshman class, writes to the same effect-Morris "was a courteous gentleman. My impressions of him were wholly pleasing." While the Rev. Dr. C. H. Merrill, of St. Johnsbury, Vermont, also a Freshman then, says:

"I have very pleasant memories of 'Tutor Morris.' He came to us, as I recall, in the midst of the Civil War, the fall of '63, the beginning of our Freshman year. He was fresh from military service. . . . He came with the prestige of tradition for fine scholarship and high rank in his class. . . He commanded our respect for his ability, and his fine personal traits made us esteem him most highly. It was a day of small things for the College in comparison with the present. The classes were small, and he was the only Tutor that year. In this way he came into competition with the professors of long standing in his care of his class, and I am sure he ranked well with them in both our regard for his scholarship and our affection for his person. He was quiet, gentle and manly withal. I recall no incident that mars our kindly memories of "Tutor Morris."” 
Apart from the experience gained, we may take it for granted that the most important event of the Tutorship occurred at the close. In July, 1864, Morris proceeded to the degree of M.A. According to the regulations in force then, he delivered an address, in candidacy for the degree, at the Dartmouth Commencement. This is still preserved, and bears the mark of the examiners "A+." The subject was characteristic of the author: Spiritualization the Law and Goal of Human Progress. The essay retains interest for several reasons. Morris adopted a standpoint which, though commonplace now, was unfamiliar then in the English world, nowhere more than in New England. Moreover, his mind had been in movement, if unconsciously. The tremendous struggle of the Civil War brought a new sense of proportion. Like all armed conflicts, it was fought out in the mire of secular 'brute facts.' It therefore raised momentous worldly interests to the same level of importance with Morris's former, and nigh exclusive, theological preoccupations. Nor did he detect any contradiction in this. Inexpugnable principles shone through the passion, cruelty and horror of embattled strife. In short, the young man had been led to adopt a broader view of life and, as a consequence, the chrysalis of his upbringing was less impervious. A few significant passages from the magistral discourse serve to hint the transformationwe are a long way from the temper of the Private Journal.

"We have therefore on admitted facts of history and a liberal analogy, the following three-fold division into stages of the passage of the human race from its rudest beginning to that ideal goal to which refined art and religious expectation unite in pointing:

"First, animal lawlessness:

"Second, Reason partially developed and the animal nature more or less arbitrarily controlled by it: 
"Third, Reason reacting against the bounds which it has itself established, in the interest of its own development, and the spiritual in man finally predominant. . . .

"The use of law is to restrain the race, during the period of its untutored development, within the bounds of that positive order without which progress is impossible.... Not that law is intrinsically transient or other than eternal, but that as assuming visible form upon the statute-book and requiring to be exerted by force, the cultivated and victorious reason finds it essentially odious. Two things apparently run counter to law: the animal nature which demands license and is destined to succumb, and the rational nature, which would not wantonly overthrow it but would suspend it by the noble and everlasting principles of love and liberty.

"We rightly look for the characteristics of the age, and the signs of the times, to that land where the theory and practice of politics and society least conflict with liberal and correct views of truth and right. Our own country now illustrates the double opposition just named.

"The worst elements of our nation, under able guidance, have excited and wonderfully organized an armed opposition to the just authority of government. This is the lower nature lusting for unshackled license. Its ends are infernal and, if securcd, minister to barbarism. It is unreasoning and passionate, and can be met only by force. It is destined to complete suppression, unless truth is to be branded with insult, God seemingly banished from history, and the bestial in man to dominate the rational. But there is also that general uneasiness under the restraints of law. ... It is reactionary in character, of no permanently dangerous tendency, and beneficial. It is to be regarded as no sign of degeneracy. It is not to be opposed by brute force, but guided and modified by reason. . . . The short-sighted complain of increasing irreligion. True, there is not that respect for the ritual observances of religion which these received in a less questioning and intelligent age. The progress of refined intelligence forbids one to regard with genuine esteem aught in organized religion except its substantial verities. Increasing apprehension of these verities and advancing spiritual culture, however they may seem for the time to foster irreverence, it were 
truly irreverent to regard as tending to anything other than an ultimate establishment on an inexpugnable basis of a generally diffused and authentic religious spirit. One of tolerably unfettered spiritual apprehension can but feel, and know by daily observation, that the religious consciousness of the age is enlarging, that any apparently irreverent elements now manifested in it are largely factitious and transient, and that men are coming to know (however distant be the day of perfect knowledge) how much and what must be submissively and may be honourably received of Truths whose denial contradicts the deliverances of consciousness or revelation, though themselves too high for the present mastery of human understanding. . . . Infidelity is now not denial of God and duty. Renan, its most recent apostle, is obliged to humanise - which in the last analysis is to spiritualiseas will be seen when the absurd notion of a normal conflict between the finite and the infinite shall have been supplanted by the better conception of their harmony in mutual aid. The variety of sects and schools only marks a transitional phase of progress from the formal and old to the new and free. From the homogeneous society passes to the heterogeneous, to be unified again in the general acceptance and practice of absolute truth. . . .

"The hand that traced on canvass the divine glories of the Transfiguration, was guided by an ethereal soul, thoroughly inspired with faith and power to conceive and reproduce the fine realities of the subject. Like inspiration rests upon the human race, to realise in thought and believingly aspire after the nobler possibilities of its own no less divine forthcoming nay progressive transfiguration out of the uncomeliness of natural deformity and weakness into heavenly beauty and power."

We also possess the following lines, of date 29th January, 1864, which reveal Morris's attitude and dominant interest at the time; farther, they lay bare the motive that led him to make the great sacrifice of enlistment. Their motto is the famous phrase from Virgil's Aneid (II. 291), Sat patriœ Priamoque datum. 
America, thou crown of all the world,

On whom the thunderbolts of war are hurled

By traitorous hands-how infamously vile!-

$\mathrm{O}$ land that art so meekly mute, the while

Red, smoking battlefields deface thy plains.

Be thou immortal! Let eternal gains

Rise from these horrid pools of reeking gore

To grace and bless thy name for evermore!

Olympic gods by no unjust decree

Can blight our hopes, $\mathrm{O}$ fatherland, of thee.

For thou, though broad and fair, yet more, art fraught,

With freedom's life, which ne'er can come to naught.

Snatched from the reckless lust of foreign kings,

To thee Humanity aspirant brings

Her gladsome praise and warmest love and hope;

So may thy life and power have boundless scope!

But let ten thousand curses blast his tongue

Who dares suggest thy hills and vales among

Truce with thy foes, tho' hellish treason's dart,

Aimed at the nation's life, should strike his heart;

Or overcast by fancied fate's rebuff,

But lisps, "for thee, my Fatherland, enough!"

So far had the secular come to mate with the spiritual for Morris!

"The hard turmoil of the pitiless sea

Turns the pebble to beauteous gem.

They who escape the agony

Miss also the diadem."

On the other hand, despite contact with the larger, grosser world, the old theological convictions appear to stand fast untouched. This prayer, written evidently to be read on opening a class, preserves not merely the inward temper but the verbal habit of New England Puritanism:

"O Lord God, in Whom alone our strength lies, we humbly come to Thee. We are utterly carnal, sold under sin. Our 
moral righteousness is as filthy rags; and there is no health in us. Do Thou, most merciful and tender Father, become indeed, in a most living and glorious way, the Father of our spirits. Redeem us from our utter, sickening spiritual destitution. Heal our putrifying moral sores. Clothe our dry bones with flesh. Vivify us in the way everlasting. And thus illustrate Thine infinite mercy and love, most signally manifested in Christ Jesus our Lord. Amen."

When we review the career to this point, we cannot but see that Morris conformed to a type-an unusual type, moreover. As a general rule, the individual life wins to a system of central control through many trials, or at the close of long probation. Uncertain of itself, it follows diverse, even incompatible, aims for brief intervals and, only after numerous slips, achieves that concentration upon a single end which is the distinct mark of personality. Thus, as has been said aptly, "Life begins in action and ends in conduct." Morris belonged to the small group of exceptions. Very early,-say, when of deliberate choice he joined the Congregational society, -he subordinated the manifold details of human experience to a coercive conviction and, as a result, grasped a purpose that governed all his reckonings. Moral goodness, as conceived by the New England conscience, provided him with a ready-made 'universe.' Here, inflexible standards of judgment kept austere order at once by their unquestioned theoretical truth and by their instant practical application. The boy was born old; not 'with a silver spoon in his mouth,' but with what, as we often forget, is no less 'unfair' and influential-a matured bent, at once solving and postponing the most difficult problems of existence.

Circumstances being favorable, such a precocious or, perhaps, premature adjustment may contrive to persist 
till death; but at a price. A man may grow irresponsive or numb, some windows of his soul being darkened. On the other hand, if stress lead to desertion of youthful convictions, this also is at a price. The pangs of change are proportionate to the strength of the original certainty. The transformation, commonly slow and silent, eventuates at length in a clear issue which, even if hostile, must be met full in the face. The thoroughness of the old belief conditions the thoroughness of the awakening, and renders its significance more profound. Morris was destined to forego the theological framework of Truth as he had it from Puritanism, and to pass through the darkness of doubt to the radiance of reasonable faith. He thus epitomized the most characteristic movement of the nineteenth century, and emerged from the struggle a significant, because a representative, personality. Arthur Clough has told the story.

"For while the tired waves, vainly breaking, Seem here no painful inch to gain, Far back, through creeks and inlets making, Comes silent, flooding in, the main." 


\section{CHAPTER IV}

\section{Union Theological Seminary. Europe. Transition}

(1864-70)

Duties at Dartmouth completed, Morris, now nigh twenty-four years old, found himself able to realize his plan, long cherished, of direct preparation for the Christian ministry. In September, 1864, he entered Union Theological Seminary, New York, as a member of the Class of 1867. Undoubtedly, the project and the institution had been canvassed anxiously with family and, in all likelihood, with academic friends. But information from these sources, about the precise reasons for his choice, fails us now. Fortunately, the Rev. Dr. Edward H. Curtis, minister of the Woodlawn Park Presbyterian Church, Chicago, a member of the same Class, is able to hint a main cause, one, moreover, calculated to exert great influence with Morris.

"I am strongly of the impression, that he chose Union Seminary because Henry B. Smith, a noted man in the field of philosophy and theology, was Professor of Theology. Professor Smith held a unique place among the theological teachers of his day. A man of wide and varied learning, a great reader, with a keen intellect and a warm heart, he won the confidence of his pupils for his intellectual honesty and his broar catholicity."

The later issue of this confidence in Smith was destined to be more momentous than Morris then knew. For it is well understood that the teacher, discerning the philosophical ability and the intellectual perplexity of the pupil, advised him to forego the ministry, and to 
proceed to Europe, there to acquire the farther equipment necessary for a philosophical professorship, Dr. William G. T. Shedd, the distinguished occupant of the chair of Sacred Literature, concurred in this advice.

Union Seminary, now so remarkably transformed and expanded, was then in occupancy of its modest early home at 9 University Place, between Sixth and Eighth Streets, near Washington Square, where everything was on a Spartan scale. Weekly board in New York City at $\$ 3.50$ sounds rather mythical, but it was indicative of the situation, as was the annual tuition fee of $\$ 10$. Notwithstanding its origin in the dissatisfaction of the New School in the Presbyterian denomination with the "high-toned" ecclesiasticism of the Old School, which had resulted in the attacks upon Albert Barnes and Lyman Beecher, Union was thoroughly evangelical, a hot-bed of temperance and anti-slavery teaching.* The founders, of $1835-6$, set forth their aims as follows:

"It is the design of the founders to provide a theological seminary in the midst of the greatest and most growing community of America, around which all men of moderate views and feelings, who desire to live free from party strife, and to stand aloof from all extremes of doctrinal speculation, practical radicalism, and ecclesiastical domination, may cordially and affectionately rally."

The Rev. Dr. H. H. Stebbins, of Rochester, New York, a member of Morris's Class, has been kind enough to give his impression of "the atmosphere of the Seminary theologically." He records,

"It was a seminary where the extremes met-the extremes, I mean, of the radically conservative and the liberal types of

* Cf. The Union Theological Seminary in the City of New York: Historical and Biographical Sketches of its First Fifty Years; and The Union Theological Seminary in the City of New York: Another Decade of its History (1888-98), G. L. Prentiss. 
personality and instruction. Professor Shedd was the extremely conservative professor. Professor Henry B. Smith was the genial, and persuasive, liberal professor. Professor Hitchcock seemed to many to be on the danger line, so far as some of his historical interpretations were concerned. $\mathrm{He}$ was by far the best preacher among the professors. He was extremely rhetorical and had a great many ardent followers. Professor Smith, however, was regarded as the safest and sanest man of all. Both Professor Smith and Professor Shedd were teachers of theology, and all three of the professors I have named were conservative in contrast to what Union Seminary stands for today. I am not speaking in the disparagement of Union. So far from that, I believe that, were the three professors in question alive today, it would be found that their views, in the light of all that has intervened since they taught, would be severely modified."

Dr. William Hutton, of Philadelphia, also of the Class of 1867, recalls his impressions of the Faculty.

"In the years 1864-67, a very large number of students [the average attendance was 110] attended the Union Theological Seminary in New York City. They came from a number of colleges, East and West-from Yale, Dartmouth, Williams, Hamilton, and many other institutions.* They were attracted to the Union Seminary by the fame of its Faculty. The professors in their various departments were not excelled by the professors in any similar institution in America. Indeed, some of them were unrivaled. Professor Henry B. Smith, the metaphysician and theologian, was professor of Systematic Theology. Dr. W. G. T. Shedd was professor of Biblical Theology and Exegesis. Professor Roswell D. Hitchcock was the learned and brilliant professor of Church History. Dr. Skinner was professor of Pastoral Theology; and Dr. Vandyke, who came from Beirut,

* The principal contributors were those: Williams 18; Yale 16; Hamilton 14; University of Vermont 8; Beloit and Union 7 each; Amherst and University of the City of New York 6 each; Dartmouth and Wesleyan 3 each. There were but nine non-graduates. Michigan men will learn with interest, that Martin L. D'Ooge, afterwards professor of Greek at Ann Arbor, was a member of the Class of 1868, and so was in residence with Morris for five months. 
Syria, to complete the translation of the Bible into the Arabic language, was instructor in Hebrew."

As was customary in these days, Morris found himself confronted with a prescribed course. There were four departments; (1) Biblical, (2) Theological, (3) Homiletical, (4) Historical. Stress was laid upon the first in the Junior year, upon the second in the Middle year, and upon the third in the Senior year. The first year, or Junior Class, studied (1) Hebrew grammar and exercises; portions of the Pentateuch and Psalms in Hebrew; lectures on New Testament Introduction; exegesis of the Four Gospels in the Greek Harmony; (2) Natural Theology; the Evidences; Inspiration and Canon of the Scriptures; (3) Lectures on the Church; (4) Lectures on the History of the World before Christ. The second year, or Middle Class, took (1) Hebrew exegesis; Isaiah, the Minor Prophets; Greek exegesis; Epistles of the New Testament; (2) Introduction to Theology; God's Nature, Attributes, and Works; Anthropology, including the Doctrine of Sin; (3) Lectures on Pastoral Theology; (4) the Life of Christ; History of the Apostolic Church. Unfortunately, we possess no direct records of Morris's reaction to the city or to the intellectual environment. On the other hand, we do know that he was most influenced by Smith, and that he disliked Hebrew, chiefly on account of the personality of the teacher, "who rubbed most of us the wrong way"; that, as a result, he vowed "to outflank it by the Septuagint." By a happy accident, records are preserved of the books bought or read by him between August, 1864, and January, 1866. These lists intimate not a little. Technical theology failed to attract him, an inference confirmed by a letter written by him to the secretary of the Class in May, 1882: 
"I was gratified to be recognized as of the Class of ' 67 in Union Theological Seminary, even though my connection with the Class was severed just at the middle of the course, and the study of theology has never been renewed by me."*

On the other hand, he read widely in philosophy, history and literature, and made occasional excursions into science. The entries contain no less than one hundred and fifty-three titles; the following are symptomatic. Hazard On the Will; Pascal; Aristotle's Metaphysics; Ackermann's Christian Element in Plato; Chalybäus' Speculative Philosophy; Mill's Logic, Comte and Liberty; Hamilton's Discussions; Spencer's First Principles and Classification of the Sciences; Lewes's Comte; Buckle's Essays; Schwegler's History of Philosophy; Draper's Intellectual Development; Kant's Critique of Pure Reason; Hegel's Philosophy of History; Clough's Poems; Taylor's Philip van Artevelde; Mendelssohn's Letters; Coleridge's Works; Carlyle's Essays; David Gray's Poems; the histories by T. Arnold, Gibbon, Merivale, Pressensée, Milman, Hallam and A. P. Stanley; Huxleys' Essays, and other works on science. It is plain that no considerations of confessional orthodoxy had influence upon his line of reading. Moreover, he could still burst into rhyme, as those verses, written in 1864 , attest.

$$
1864-1865
$$

Die into History

Reeling old year!

Storm-clouds of mystery,

Fable-born, drear,

Hang on his rear!

* After Fifteen Years: Report of the Class of 1867, of Union Theological Seminary, New York. Edited by Henry M. Booth (1882). 
Weave thy new History

Welcome-new year!

Publish thy mystery:

Hope, the far-seen,

Overrides fear.

\section{Shakespeare}

Shakespeare, of name undying!

Thy fleshly heart, low lying,

Responsive beats no more

As in the days of yore,

To vexed humanity's deep sighing.

But in thy living pages,

'Twill need no keen-eyed sages

Forever to descry

Such life-blood coursing high

As feeds the strength of all the ages.

Two short papers survive from this period. Their date is February, 1865, and they were written evidently to be read at a student society. The topics are-The Practice of Preaching among Theological Students while still in the Seminary, and Artist, Poet, Preacher-the Greatest of These is Which? Both betray a maturity, and a vein of irony, due to unrest or dissatisfaction, scarcely characteristic of the average seminarian. Indeed, as we shall see, Morris's contemporaries noted just these qualities. One would like to have heard the discussion elicited by the following passages.

"From the circumstances of their previous life, they [the seminarians] are not so fully prepared in personal experience and ripe study and thought as they should be. . . . They need more of time devoted to preparation than do those entering the legal or medical profession, since these have to do with specific and in general easily defined topics or cures, whereby nothing is required but to apply well-known rules; while clergymen need familiarity with the multitudious phases of character and modes 
of spiritual development; to appreciate these properly mature study and reflection are indispensably requisite. . . . With no proper conception of the magnitude and vital import of the truths which they are to vindicate and apply, with nothing in many cases of fixed and hearty belief arising from independent investigation, they suppose the mere formal mastery by the memory of a set of prescribed doctrines to be a sufficient outfit for their life's work, as though the course of study and training in the Theological Seminary were like an apprenticeship for the practice of a mechanical art. No amount of emotional piety can meet the want of thorough and thoughtful mental culture in one who proposes to unfold and enforce truths which the angels desire to look into. . . Truly such strangely interpret Paul's admission as to the foolishness of preaching. . . .

"The practice of preaching while yet students in the Seminary implies too low an estimate of liberal studies. Not to speak of their influence upon the preacher as an antidote for narrowness of views and illiberal dogmatism in opinion (on which, alas, experience shows the most sincere religious character to have no preventive and but little palliative influence), these studies are increasingly common among the masses. Their influence is growing with amazing rapidity.... As things are now, they are likely to be misinterpreted so as to furnish the short-sighted, and many sincere men who have not time or ability to examine them, with arguments for infidelity. Now religion, in its commonest present acceptation, involves the support of certain dogmas in the form of verbal propositions which constitute a great part of our real or supposed knowledge. The belief in them . . . is likely to be affected by such generally accredited and well substantiated facts as do really, or may seem to, invalidate them. In either case, the defender of religion from the pulpit, who is not familiar with the facts and their proper explanation, deserves not, and will not receive, the full respect of the generality of hearers. Nay, he wastes his influence with many, appearing positively ridiculous.

"The practice obstructs the advancement of theology. This is a progressive science. . . . The increasing light of accumulating experience and continued reflection varies considerably the verbal expression of the objects of Christian faith. That there 
is reason for farther change cannot be logically denied on any ground, and is particularly evident to many, since, were this not so, it is incredible with them that certain dogmas should be entertained for a moment in this 19th century. In their view,and I think it is just,- -nothing but the inconsiderateness with which theological students found themselves on a prescriptive faith ... prevents theology from a considerable and speedy enfranchisement from the puerilities and mistakes of darker ages."

"Art, poetry and religion are the actual and representative expression of humanity-the one sentimental and ocularly discerned; the next imaginative, the exponent of creative power; the last moral, and the preëminent index of character. . . . Let divine power accomplish its utmost for the religious life of man, it still transcends Omnipotence to do more for him in this respect than develop his underived potential spiritual possessions without making him præter-human - a thing which no one, since the days of apotheosis, has a right to look for. . . . History most amply justifies our implied allegation of what may be called the spontaneity of the trio under consideration. Their universality, the absence of special external causes which could be supposed to account for them by force, and the conscious free-will of man, combine to show conclusively that art, poetry and religion are ultimate facts among men. Nascitur, non fit, truly describes man regarded as the living subject of each. . . .

"The consideration of more recent times is unnecessary to furnish testimony to the universality, spontaneousness, and alliance of religion and, as they may now be called, its servants, poetry and art. This only has almost without exception been peculiar to the case thus far,-that, while the poet and artist, except when the subserviency of their functions to religion degenerated into servility, have wrought largely under the mastery of passion, with a dominant sentiment of love for their work, the religious functionary and the devotee have lacked this vivifying element. Religious love was rare indeed previous to the incarnate revelation of God as Love, and since, even to this day, we know too well how seldom and feeble its manifestation. Moral ruin, for obvious reasons, affects the religious side of man more destructively than any other. What marvel that its 
restoration be more slowly effected, and that the contrast between the bright and healthful inspirations of all untrammeled art and poetry, and the gloomy and really burlesque human developments of religion, should embolden scoffers and the shortsighted, to suspect the essentially human and divine character of true religion. Here art and poetry are the faithful allies and renovators of religion."

To what extent Morris was aware of his 'lapse,' we have no means of estimating now. But, on the face of it, he was reacting decidedly against the jejune notions common to Paley and to the exponents of current Protestant orthodoxy, who continued in the outworn ways, as if Hume and Kant had never come for judgment and for reawakening. The purport of Hegel and the historical school begotten by him was, of course, entirely misunderstood or, more often, overlooked.

In any case, we have ample evidence that his contemporaries in the Seminary recognized in Morris a man beyond their attainments, and discerned something of his unrest. Thus, Dr. Curtis writes:

"I did not know Morris intimately. He was considerably older than myself - very mature and thoughtful. By his attainments, he seemed fitted for post-graduate work. I have always felt that he was in a state of perplexity over not a few doctrines of the church. But he was not given to airing his doubts. He impressed me by his reverence. He was never flippant. I admired him, and wondered how the struggle over his religious beliefs would come out. . . He impressed me as a man of beautiful spirit, who was 'feeling his way' to a system of philosophy that would satisfy his reason. I did not become acquainted with the processes of his thinking, while I recognized the fact he was an unusual thinker, for a man of his years. He admired Prof. Henry B. Smith, who was a philosopher as well as a theologian, and a man of broad and generous spirit. I somehow felt that Prof. Smith was the only man in the Faculty of Union Seminary who particularly interested him ... who, 
by his ability, firmness, and keen analytical thinking, left some mark on Morris's mind."

\section{Dr. Hutton's testimony is to similar effect:}

"Morris was noted for his quietness, seriousness, and always appeared to be in a thoughtful mood, as if pondering some deep problem in theology or philosophy. The student body represented many denominations: and the discussions revealed quite a diversity of views on the great and fundamental doctrines of Christianity. Mr. Morris appeared to be somewhat unsettled in his views regarding some of the doctrines taught. He was somewhat wavering regarding certain interpretations or explanations of Bible truth. Prof. Smith was both a philosopher and a theologian. He was Professor of Mental and Moral Philosophy at Amherst College prior to his election to the Professorship of Systematic Theology in Union Seminary. He was a man of great learning, quite familiar with all the philosophical and theological views advocated by the different schools. $\mathrm{He}$ allowed the students to question him freely on all subjects, and in these questions the bent of the students' minds was revealed. Mr. Morris was in great measure the young philosopher. His questions showed that he was a deep thinker and an earnest searcher after truth. He was seemingly anxious to reach a clear and satisfactory view of the great problems of sin and redemption. And, during these discussions, Prof. Smith, in a most masterly manner, corrected the misconceptions of the students."

\section{Again, writing to Miss Morris, Dr. Hutton says:}

"Your father was in manner serious, thoughtful, and unusually reticent. He was present regularly at recitations, was a good scholar, and impressed me as a young man of superior ability. In the class discussions, and in the questions he propounded to Prof. Smith, he displayed great mental acuteness, and great fondness for philosophical debate. I regarded him as indeed the philosopher of the class. But he did not seem to have any strong convictions regarding certain fundamental theological dogmas. His mind seemed to waver, to be in some doubt, to be unable to heartily assent to the doctrines advocated by Professor Smith and accepted by the students generally. . . . Dr. Smith 
was a master both of philosophy and theology. His answers to questions that seemed unanswerable were most helpful to those who were in doubt. ... What change he effected in your father's views, of course, I cannot tell."

The Rev. Dr. Moseley H. Williams, of Philadelphia, offers an interesting side-light on possible reasons for the dissatisfaction felt by Morris. As a member of the Class of 1867, he says:

"We were in Union Seminary together in 1864-6. I recall him as rather pale, intellectual in appearance, quiet in manner, and keen in observation and expression. I was not thrown into such intimate relations with him as to have recollections of much value. . . . As to the philosophical atmosphere of Union Seminary, we had Prof. Henry Boynton Smith, one of the finest intellects of his day, a New Englander by birth and training, a man of marvellous learning and power of expression. $\mathrm{He}$ certainly had the philosophical mind and training; but a Theological Seminary really does not go into theology very deeply at any time, and we were living in the midst of the excitements of the Civil War, when the stirring events of the times gave a practical turn to our talk."*

We know from Morris's own experience a little earlier, how overmastering this preoccupation was in certain religious circles. And it may very well have been that the conditions prevalent in the Revolutionary era, so clearly drawn by Professor Van Tyne, reproduced themselves somewhat in the Seminary.

"The Americans were not only Protestants, but protestants from Protestantism itself, and from this fact, as Burke expressed it, a fierce spirit of liberty had grown up. This spirit the dissenting clergy communicated to a people far more influenced by what they heard in the House of God than we in these degenerate days can comprehend." $\dagger$

* The italics are mine.

† Cf. "The Clergy and the American Revolution," The American Historical Review, Vol. XIX (Oct., 1913), C. H. Van Tyne. 
At all events, for other reasons, if not on account of this insistent practical interest, Morris felt that he was not getting at the fundamental things. The noise of the armed strife distracted all from deeper questionings as to theological subjects.

During his first year of attendance at the Seminary, Morris doubtless drew his own conclusions about the tendency and sufficiency of the instruction. I infer that, like some students of my own acquaintance in similar circumstances a generation later, he felt the lack of reality, and the failure to consider clamant problems without mental reservations. As the early months of the second year (autumn of 1865) passed, his desire to go to Europe grew more urgent; he sought ways and means. Then, too, his teachers, thanks to farther intercourse, cannot but have been in a better position to diagnose his case, and to advise him frankly. It is clear that, Professor Smith aside, ${ }^{*}$ the move came entirely from himself.

* Henry Boynton Smith was born at Portland, Me., in November, 1815; graduated from Bowdoin in 1834; studied theology at Bangor and Andover. Thereafter, he went to Halle and Berlin, where he became intimate with Tholuck, Ulrici, Neander, Dorner, Godet and Khanis. Godet, writing to Mrs. Smith just after her widowhood, refers to Neander as Smith's and his spiritual father. Like Neander, Smith was, on the whole, a follower of Schleiermacher, and it is to be noted that, as the names of his German friends indicate, his sympathies lay essentially with the 'School of Conciliation.' He was most at home in historicophilosophical treatment of theological topics, as his reviews of Draper, Mill, and Whedon attest. His volume, Faith and Philosophy (1877), consisting chiefly of reprints of articles from The Presbyterian Review, and the earlier work, The Idea of Christian Theology as a System (1854), give an adequate notion of his position. His posthumous Lectures on Apologetics (1882) offer many hints as to what Morris derived and, equally, could not obtain, from his teacher. For him, as for so many, the School of Conciliation ran with the hare and hunted with the hounds. After holding the Amherst chair of Philosophy for three years, Smith came to Union Seminary, to undertake the professorship of Church 
As was natural, the family had many misgivings. Mrs. Cone writes:

"I remember his coming with his sister Lucy to tell me that it was decided he was to go to Europe. We sat round the dining-room and talked it over, as if it were a great and important event, as indeed it was to him and to us all."

This interview took place in late January or early February, 1866. The family feared "lest German philosophy should destroy his religious faith." Four letters-from his sisters, Lucy and Susan, and from his parents-prove that the project had become acute during the Christmas vacation of $1865-6$, and that he must have remained in New York pending necessary arrangements. The letters are dated by day names only, except that from his father, of date 20th January, 1866. This date, with internal evidence in the other letters, enables me to date all four approximately. The communication from Lucy was the earliest; it was written either on the 21st or 28th December, 1865. At this time, Morris himself had quite decided upon European study; but the troublesome financial question barred

History. The change from New England Congregationalism to New School Presbyterianism was a difficult one. But he had counted the cost, and knew what he was doing. A letter, written in September, 1850 , serves to throw light upon the peculiar situation of Union Seminary, alike as to opportunity and limitation. "I go to New York in full view of all the uncertainties and difficulties of the position. The literary character of the Seminary is slight, its zeal in theological science is little, the need of a comprehensive range of theological studies and of books thereto has got to be created. Its theological position is not defined." Within a few months of his removal, he became influential; was transferred to the chair of Systematic Theology in 1854; and, thereafter, grew to be one of the most conspicuous, trusted and powerful leaders of his adopted communion. After 1868, the continuity of his work was sadly interrupted by sickness. He died in 1877. Cf. Henry Boynton Smith, his Life and Work, by Mrs. Smith (1881). 
the path. The situation was such that opportunity offered to express the grave dubiety of the family circle. One paternal letter runs:

"Let me caution you against too great trust in Mr. Larrowe.* Use your own judgement, and do not be dazzled by the brilliant prospect of going to Europe. You will not misunderstand me when I say, that it will not be wise for your own peace of mind and happiness if you go to Germany, and plunge into German abstractions, without a firm planting of your belief upon experimental Christianity. I don't want you to become befogged in metaphysics, and lose aught of simple trust in or obedience to the doctrines of Christ crucified. That is my only fear for you. One must be stayed upon the Rock of Ages before putting out in the contentions of metaphysics. I think faith and works are both necessary. Don't give yourself up to the opinions of Larrowe without knowing that you do it, and the wherefore. I caution you thus, because I should need the same were I in your place."

Meanwhile, events moved so rapidly that, on the 18th January, 1866, the family received a letter, announcing that the trip was assured. The first reply to this is from Morris's sister, Susan. Characteristically enough, her letter comments upon the prospect in a brief and matter-of-fact manner, and then proceeds to give a long account of revival meetings then in progress at Norwich!

"Your letter to Father, which came yesterday, has been read and 'contents noted,' and meditated and reflected on. ... For my part, I suppose I ought to congratulate you upon the near prospect of having your ambitious desires gratified. I am very glad for your sake; but for my own part I don't know as I like the idea of your going off so far without seeing you for three years, neither do I think the receiving 'letters from Germany'

* As appears from the letter of Mr. Sylvester Morris below, Mr. Larrowe was very soon to loan or give-which I do not know-Morris $\$ 3000$, to finance the trip. 
will compensate for your long absence. But then, if you must and will go, we must make the best of it."

The father's reply is that of a practical man, and takes the essential point admirably.

"I was pleased, and so was your Mother, to think the man you speak of took so much interest in you as to give you $\$ 3000$, to spend in Europe.* But it is not so pleasant to your Mother to

* Unfortunately, I have been baffled in every attempt to determine why, or under what circumstances or conditions, Mr. Larrowe furnished Morris with this considerable sum. On the other hand, after long and, as it appeared for two years, hopeless search, I have been able to identify the benefactor. He was Marcus Dwight Larrowe, born in Cohocton, Steuben County, New York, 5th May, 1832. He entered the Class of 1854 at Yale in the Sophomore year and, after graduation, was a student in the Yale Law School till February, 1856, when he was admitted to the Connecticut bar, and immediately settled in New York City, where he practised his profession. In the spring of 1861 , he removed to Nevada, which he had visited in 1859 . In the spring of 1863 , he was appointed District Attorney of the Territory, and resided at Carson City. In August, 1863, he was elected a member of the Constitutional Convention and, under the eonstitution then framed, was made a Judge of the Supreme Court. He never filled this position, as the Court failed to receive ratification from the people. Nevada having been admitted as a State, in 1864, Mr. Larrowe was elected a member of the State Senate for four years. He returned to New York in 1865 and, in 1866, decided to remain there. He had evidently been engaged in "business schemes" (probably mining) in Nevada, as well as in politics and in the practise of law; and he had been successful. So far as the records establish, he continued to practise law in New York till 1868. Thereafter-the date is uncertain-he abandoned his business activities "to take up a scheme for developing the memory. He gave private lessons for a while in New York. In 1874 he went to London, England, and changed his name at the same time, so that, if failure did result, no embarrassment might attach to the family name. This accounts for his assuming the name of Alphonso Loisette, by which he is so widely known." He gave lessons in London and, after 1880, was accustomed to lecture on the subject of Memory. He returned to the United States in 1886, leaving a manager at his London office. "After his return, he passed a few months in New Haven, Connecticut, and then located in New York City, where he had classrooms at 237 Fifth Avenue till April, 1893. 
think that her George is to be gone so far from home and that she will not see him for three years or more; and she wants to

In November, 1894, he sailed for Europe with the intention of making a lecture tour round the world, which he carried out. He arrived at San Francisco on January 21st, 1896, and died at the Palace Hotel there on 5th February of the same year." Soon after his return to the United States, "Loisette" appeared in Ann Arbor. The Michigan Argonaut of 19 th Nov., 1887, says: "An attempt is being made to work up an enthusiasm among the students in the interest of Professor Loisette's memory system. . . . The success which the system is meeting at Yale ... and the testimonials received from prominent men, certainly indicate that there must be some real merit in his method." By 10th December it was able to announce that an advance agent was to "arrange all necessary preliminaries." Finally, "Loisette" gave an introductory lecture, attended by " a large crowd of from 500 to 600 ," and gathered a class of "nearly 400 members," who each paid a $\$ 5$ fee. The aftermath was not pleasant. The issue of 11th January, 1888, says: "Loisette has come and gone. The criticism which one hears is usually of an unfavorable sort. . . He left numerous printed slips, and in place of these and several lectures, has taken away with him two thousand dollars or thereabouts. Many students have a very distinct recollection that they paid five dollars, and that is the most they know of Loisette or his discovery." While the issue of 11th February classes Loisette with some faith-healing quacks then operating in Ann Arbor, and concludes: "If a fakir should come along selling gold watches at $\$ 2$, Ann Arbor would probably buy him out." Such an episode, together with this "Christian Science" and the $\$ 2000$ we "blew in" on Loisette, would make a trio of fooleries which would be hard to beat" (Cf. The Palladium for 1888, the year-book of the Michigan graduating class, p. 174.) I am indebted to Mr. Alfred K. Merritt, Registrar of Yale University, for the facts concerning Larrowe's earlier career. Further light is thrown upon the somewhat doubtful episodes of his "Loisette" period in Memory Systems, New and Old, by A. E. Middleton and G. S. Fellows, pp. 96 f. (New York, 1888). Mrs. Morris writes that "later in life Mr. L. defrauded Mr. Morris of considerable money." The references dropped by Morris père- " "let me caution you against too great trust in Larrowe; dont give yourself up to the opinions of Larrowe without knowing that you do it, and the wherefore"-led me to conjecture that his ideas, whatever they were, might have exerted some influence upon Morris's mental development. But the fact that they cannot have met till the autumn of 1865 proves that their intellectual intercourse, if any, was no more than a brief incident. 
know what the advantage of Germany is for studying over New York or the best places in this country, or what you will learn there that you could not have here, or what it is you want to study. I do not know enough to tell her, of course, and advise you to answer. For my part, I have ever thought you were better fitted for a Professor in some college than for a Minister; or rather, I have had fears that your lungs or throat would trouble you if you were to preach constantly; but in teaching you have thus far been successful, and that is what I think you were made for."

His mother wrote a touching note, the more pathetic to us who know that she passed away ere his return.

"Upon the subject of your going to Germany, I can only say from my own standpoint, if it is the way you can 'best serve your day and generation,' to give so much more time to study before entering upon the ministry, which I suppose you still have in view, I of course must be content to let you go. When I read your letter, the tears came plentifully at the thought of such a long separation. The thought soon comforted me that it would not be eternal, if earthly. What glorious prospects before us poor pilgrims of earth, if faithful unto death. God grant that we may be. . . . Susie is very much affected; she stayed to be conversed with last evening. Good morning; and may God Almighty be with you always to guide and to keep."

The reference to "Susie" is of particular interest. Despite other preoccupations, Morris had found time for affairs of the heart. There was a mutual attraction between him and Miss Susan Denison, of Royalton, who had been one of his pupils there. As a result of correspondence, they became engaged in the spring of 1867. She was the youngest child of Dr. Joseph A. Denison and his wife, Eliza Skinner. More than seven years his junior, she was less than twenty at the time of the betrothal. Dr. Denison came of an old family, the most prominent in Royalton, where the 'old Denison 
house' still stands, the largest and handsomest in the village. Mrs. Cone records that the couple were "admirably suited to each other," and that "an alliance there would have meant everything desirable according to New England standards."

Before we pass to the European sojourn, let us take stock for a moment. We have a young man-just turned twenty-five, it is true, but with a wealth of experience behind him. Representative of a culture which dated from the Reformation, and had become keenly conscious of itself in the Puritan Revolution, he had inherited a group of complex ideas that sufficed him alike in the intellectual and the practical arenas. Notwithstanding his unconsciousness of them, the notions fathered by Sydney, Milton, Locke and Hoadly, set his perspective in secular affairs. The fervent Abolitionism that swept him into the Northern army was no more than their logical consequence. On the other hand, in the things of the spirit, he was born a veritable embodiment of his folk-of whom Governor Pownall (1769) could affirm in Parliament, "The spirit of their religion will, like Moses' serpent, devour every other passion and affection." He had been reared amid a society into which the bare possibility of scepticism about the dogmas of Protestant Christianity had scarcely entered. As a result, his studies at school and college, pursued with exemplary diligence and eminent success, however they may have disciplined his powers, did nothing to transform his intellectual life, and left his moral judgments untouched. He proved so impervious that his acquirements remained external to his vital outlook. He enjoyed the usufruct of a pervasive system of truth, which had come to him without any effort on his 
part; its foundations and defensibility he had never examined. The army episode may have opened his eyes to see men as trees walking. But, so far as we know now, this awakening bore upon human nature and its weaknesses in daily conduct, never upon the fundamentals of belief, which continued a free gift, so to speak, and therefore lacked both the reality and the impregnability of possessions hard won by personal effort.

When he passed to the Seminary, he had laid his sacrifice upon the altar of the chief contemporary question and, to some extent, his interests had shifted. He was beginning to seek his own foundations for the faith that he had merely accepted hitherto. Briefly, his intellect was really stirred for the first time. Unquestionably, this change overtook him slowly and, in the end, caught him unawares. A long, varied course of reading, coupled with the new ideas 'in the air' of the time, had their effect at length. At that period, and in these circumstances, even Union Seminary was ill calculated to ease his troubles. For, after all, a seminary, as a rule, lays more stress upon preparation for the working pastorate than upon discovery, or even statement, of first principles. The confessional basis necessarily obtrudes itself, and arbitrary positions cannot be avoided. The appeal to reason as the final arbiter of truth belongs to the exceptional man, who appears very rarely-who could not appear then, at all events in a theological school. When he turned his face towards Germany, Morris had sensed these trammels. Yet, although he may have determined to probe things more systematically, he could not have foreseen the enormous changes of standpoint, method and general 
atmosphere, that awaited him over the water. The Germany of 1866 was nigh two generations ahead of the English-speaking world in treatment of philosophical and theological problems, and even farther removed from the United States than from England. Hegel, who, in this very year, was just beginning to be noised abroad in Scotland, thanks to Hutchison Stirling, ${ }^{*}$ had run his course in his native land. The Hegelian school had fallen to pieces long since; the fever of materialism had passed its crisis, and the Neo-Kantian movement had set in with F. A. Lange's History of Materialism. $\dagger$ On the contrary, the Protestant preachers, who filled American chairs of philosophy, were still winning bubble reputations in the 'free will' controversy, serenely unaware that Vatke, in his epoch-making work, Human Freedom in its Relation to Sin and Divine Grace, had rendered the quarrel meaningless a quarter of a century before. $\neq$ It is true that Shedd, fresh from the influence of James Marsh at the University of Vermont, had brought an intimate knowledge of the teaching of Coleridge to Union Seminary. $\$$ But Morris found this mystic idealism associated with orthodoxy of the old Augustinian and Calvinistic type which, as we are told, grew stronger with his teacher's advancing years. So, too, in the realm of theology, even D. F. Strauss was ancient history for the Germans, and the best of the

* Cf. The Secret of Hegel; being the Hegelian System in Origin, Principle, Form, and Matter, 1865.

$\dagger$ Lange began this work in 1862 .

$\ddagger$ Cf. The Value and Destiny of the Individual, B. Bosanquet, p. 113, note 1 .

$\S$ Cf. Shedd's Introduction to his edition of Coleridge's Works (1853).

II Cf. Another Decade in the History of the Union Theological Seminary, G. L. Prentiss, p. 419. 
'liberal' Lives of Jesus, that of Keim, lay little more than a year in the future. Thoroughgoing scientific handling of biblical and historical problems had been naturalized in the universities for forty years, and many of the original investigators who gave Germany her unchallenged leadership in the human sciences during the middle nineteenth century, were in their prime. Little witting all that the venture implied, Morris was about to cast himself into the main stream of modern European thought, then and there at 'angry flood.' Possessed at once of the background and interests to appreciate the vast import of the questions, and of the equipment to work upon them personally, he was rarely fitted, and veritably fated, to undergo a complete displacement.

On Thursday, 8th February, 1866, Morris took leave of his relatives at the Vermont home and, on the 10th, sailed from Hoboken, aboard the North German Lloyd steamer New York. As his Diary tells us, he "pondered the mysteries of suffering, especially sea-sickness," for several days, and did not blame himself "for being so human as to forget for a short time ambitionsGermany, Metaphysic, Logic.” Nevertheless, it appears that metaphysic exacted its due; he read Shadworth $H$. Hodgson's Time and Space: a Metaphysical Essay (1865) on the voyage-a stiff dose. "It was with feelings extraordinary" that he first "looked on English soil," off the Isle of Wight. By the evening of the 24th he had reached Bremen, where "the streets are refreshingly clean after wandering in the slush and filth of New York." The Sunday morning service in the Dom "was an altogether new sight, strangely affecting me;-so different was it from anything I had seen or could see 
in America in style and arrangement, and so various and profound were the emotions excited at the architectural, pictorial and commemorative expressions of Christian faith and reverence which it contained... . It gave me for the moment a kind of inspiration, and yet set me again desperately at work over the problems of Christianity." $\mathrm{He}$ deemed it "indescribably strange and agreeable, and felt glad enough at the thought of the great privilege." From Bremen he went to Cassel, in Hesse Nassau, where, attracted by the city and surroundings, he remained to improve himself in the language. After a fortnight, he notes, "I am getting into working trim; make my seven hours a day now comfortably." Nor has he been remiss in arranging for study. He has heard from Professor Ulrici, of Halle,*"shall go thither next month." The solemn observances of Holy Week impress him profoundly.

On 2d April he arrived in Halle, where "Prof. Ulrici gave me the most cordial greeting imaginable." Despite their urgency, German and philosophy do not oust music altogether. He goes to Leipzig, to hear concerts at the Conservatory, and remarks: "I have a piano in my room and enjoy practising very much. I have the use of a musical library; am in particular raptures just now over Nos. 4 and 31 in Mendelssohn's Elijah. But, study is the principal thing: "yesterday, exactly two months after my landing in Europe, I commenced

* Hermann Ulrici (1806-84), a critic of Hegel; best known for his works On the Principle and Method of the Hegelian Philosophy (1841); The Ground-principle of Philosophy (1845-6); System of Logic (1852); God and Nature (1861); his Shakespeare's Dramatic Art (1839) was translated into English (1888) from the third German edition (1868), and by it he is remembered in the English world. An admirable type of the German philosophical scholar of the mid-nineteenth century. 
hearing lectures,-subjects, Logic, and History of Philosophy; both by Prof. Ulrici." American and German ideals clash at a dinner with the Ulrici family. The professor "believes not in the permanence of our American Republic. His ground principles were very poor. He admitted it more reasonable to elect a ruler than to obtain him by inheritance; but, then, we were liable to make a bad choice, and inevitably must do so, when we should come to have $10,000,000$ voters! Matters of religion and politics, he said, were all in the region of faith, on which all depended. Then I had him, when I told him we believed in progress in America, and could not therefore go back to monarchical governments."

In late June, the semester ended, we find Morris in Dresden.

"Wearied with hard study, a bit worn through foolish anxiety, I determined to give myself the pleasure and recreation of a first visit to this noble city. ... At 12 o'clock the Picture Gallery was opened, and I rushed for the Sistine Madonna of Raphael. I expected to be wonderfully impressed, and was not in this case disappointed. It was so far surpassing all my conceptions! I shall love always just to sit and think of it. Not its grandeur at all, but the inexpressible innocent beauty of the Virgin Mary, and the speaking life of the other faces, together with the beautiful colours, are what produce the effect within me."

After three thrilling weeks, he returned to Halle, where he was present at the inauguration of Beyschlag as Rector of the University, and heard the New Testament theologian deliver "a tedious address on Schleiermacher." The arrival of Prof. Henry B. Smith from New York, and dinners with him at Ulrici's and Tholuck's, gave keen pleasure. August saw him in Frankfurt, after various excursions, to the Brocken and other points of interest. 
Late in the same month, he moved to Lausanne, where, as he says quaintly, I "first saw a monk." Here he made the acquaintance of the eminent philosophical theologian, Astié, of whom he was to see a good deal.* The fact that Astie had been for a time pastor of the French Protestant congregation in New York, formed a direct bond of sympathy. Morris writes:

"I like Lausanne. It is a great improvement on Halle in the neatness of the town and people. $\dagger$ I seem more as if I were among civilized people."

Geneva did not please him especially, although he heard Molière's Le Tartuffe and Corneille's Polyeucte"the latter grand and noble in the extreme." $\mathrm{He}$ prolonged his stay in Switzerland for five months, till 24th January, 1867, engaged closely in study of French and of philosophy. He refers to an article on Hodgson's Time and Space, which he is writing for H. B. Smith; and he records that he read Aristotle's Metaphysics (in Greek and French); Ravaisson's Essai sur la Métaphysique d'Aristote; Cousin's Histoire Générale de la Philosophie; Zeller's Philosophie der Griechen: Hauréau's De la Philosophie Scolastique; Vacherot's La Métaphysique et la Science; Caro's L'idée de Dieu: the tragedies and comedies of Racine, Corneille and Molière.

Lausanne had grown upon him. "I did not realize

* Jean Frédéric Astié (1822-94), professor of philosophy at Lausanne, was also a member of the School of Conciliation, having been influenced more especially by Rothe. He wrote a number of works which have real historical interest as illuminating the controversy between the moderate and rationalist wings of French Protestantism. His opposition to Scherer, and his labors as founder and editor of the Revue de Theologie et de Philosophie, rendered him a prominent and significant figure in his day.

† For the ugliness of Halle then, ef. Germany, its Universities, etc., P. Schaff, p. 72. 
the pain my departure would give me. All my friends there manifested extreme kindness and interest in me. At Mr. Louis Joël's, architect, now Mayor of Lausanne, the evening before I left, a sort of wine soup was made in my honour-a dish peculiar to occasions of separation among them." His journey lay through Bern, Basel and Frankfurt, to Halle, where acquaintances met him; and "it relieved my dismal homesickness for Lausanne somewhat to be among these friends." Dr. Ulrici gave him a letter of introduction to Trendelenburg, whom he visited on the 30th January, 1867, and who helped him to the use of the Royal Library. Berlin did not attract him; his Lausanne friends urged him to return and, such was his nostalgia, that he almost decided upon precipitate flight. He notes

"On the other hand I am begining to learn the great advantages of being in Berlin. . . . It may be of great advantage to me to hear some of the lectures here . . . though, in general, I can employ my time to better advantage in my room than in the lecture room."

The musical facilities entice him and, by the middle of February, he is less unsettled, letters from home giving him comfort.

"Somebody whom I have long admired and loved, tells me she 'thinks dearly of me,' and this fills my cup of satisfaction rather more than to the brim."

Notwithstanding, the call of Lausanne proved irresistible ere long and, on 27th February, we find him in Munich, "the modern Athens," after a visit to Nüremberg, en route for Switzerland. Thence he went, via Augsburg and Zürich, reaching Lausanne on 2d March, where he settled down contentedly. Among special pilgrimages was one to "the tomb of Alexandre Vinet," 
at Montreux. And, so for nigh another five months, life sped smoothly and profitably, till the terrible blow fell, which drew the stricken words of 26th July. "On July 1st, I received the dreadful news of my mother's sudden death. What anguish and grief it has cost me! . . . No mother to welcome me when I return to America. God's will be done."

The bereavement wore upon him, for, on 17th August, he wrote:

"Half-sick with fatigue, heat, disappointment and expectation, I made up my mind for a trip to Chamounix."

Some mountaineering served to refresh his spirits and, by the end of the month, he is in Paris, where Patti entranced him several times.

"To-day, Thursday, 31st October, I happened to pass the Luxembourg as the Emperor of Austria left it. So I have seen one of those who are called sovereigns."

The New England conscience could not be downed!

At the beginning of November, he travelled to Cologne, on the way to Berlin, where he resided for the first semester of $1867-8$, giving himself ardently to philosophy. He attended two lectures a day, hearing Trendelenburg, Meyer, and Hause, and worked, in Trendelenburg's seminar, on Aristotle's Ethics. As if this were not enough he asked Michelet "to recommend me a person who could read Hegel with me." The single indication of his philosophical standpoint at the time (given by the Diary) occurs now.

"Last Sunday [18th Nov.] we were addressed by a minister who had the folly to say that Plato was indeed a great thinker, but that no one would think of reading him, now that we had Locke! Aristotle, too, dug deep, but Hamilton had dug deeper into the mysteries of philosophical problems! This reminds me 
of my theological class-mate who was fond of calling General Butler a 'deep thinker'! What are we Americans coming to, with our superficiality?"

During his Berlin sojourn, Morris gave constant attendance upon all sorts of musical performances.

At the close of the semester, in March, he paid a second visit to Dresden where, as he records, "I met Prof. Chapin,* of Ann Arbor, Mich., and had a long talk with him." The galleries arouse his enthusiasm once more. Brief stays in Prague, Vienna, Venice, Bologna and Florence followed, on the way to Rome. Prague impressed him deeply and, in Vienna, "everything is on a grander and finer scale than in the Hauptstadt of North Germany." Ecclesiastical Rome being still in its glory, he witnessed the ceremonials of Easter, 1868. On Palm Sunday, he attended St. Peter's; "curious," he comments, "but, to a Yankee, not imposing." Again, "we went to see the feet of pilgrims washed . . . the dirtiest and most unintelligent looking men and boys I ever saw. . . . They behaved well enough, but, oh! my God, what rays of intellectual or spiritual light can have reached their minds and hearts?"

He was more impressed by the scene at the Papal blessing, from the Loggia of St. Peter's, on Easter Day, and the evening illumination of the Basilica

"was one of the grandest sights I ever saw. . . . By isolating the church under the opera-glass, so as to see only it against the background of the sky, one had what could almost be taken for a golden palace of the New Jerusalem-or a work of fairies."

A visit to Naples followed, with the usual experiences at Vesuvius, Pompeii and Capri; thence by boat, to

* L. D. Chapin, professor of philosophy after Tappan's dismissal (cf. American State Universities, Andrew Ten Brook, pp. 256 f.). 
Leghorn, and on to Pisa, Florence and Milan, reaching Lausanne again on May 4th, to find a cordial greeting from friends. Although he lingered here till 20th August, the Diary practically closes with his arrival. He went north by Paris and Havre, was "very seasick," crossing the channel to Southampton, on 27th August. On the 28th,- - having seen nothing of the land of his forebears, he sailed for New York by the steamer Allemania. A dirty, disagreeable voyage may have elicited those sentiments: "The passengers are for the most part German-Americans. A disgusting lot." For, on the outward voyage, "the passengers were mostly Germans, very fine people." The second week of September found him in America, after an absence of two years and seven months.

The Diary throws little, if any, light upon the course of his intellectual development in Europe. Moreover of the few extant letters, addressed to relatives, the majority (twenty-six or thirty) belong to the earlier period of the Wanderjahre, and duplicate the contents of the Diary. They are records of events and observations; the drama of the soul, whatever it may have been, never obtrudes itself. Nor is this wonderful; Europe was a panorama, and Morris was ever reticent in the extreme. We gather that, despite fits of Heimueh, he was "very happy"; that he "never studied better"; that he "received many nice letters from Royalton" (from Miss Denison); that "the mental activity of the German nation astonished" and captivated him. We may infer, from numerous pious expressions, that he preserved his evangelical traditions substantially for two years at least. In this connection, however, one significant incident occurs. A student friend, little his 
senior, had preached at Lausanne, and it was suggested that Morris's "turn came next." He remarks, "I never wrote a sermon, and have no time for it now." It is quite evident that he had as much inclination as time! The vocation of the ministry had been abandoned finally (Dec., 1866). The fit of the 'blues' that afflicted him at Berlin, in February, 1867, and drove him back to the congenial environment of Lausanne, was undoubtedly caused by the anxiety with which he awaited Miss Denison's reply to his proposal of marriage, and aggravated by apparent neglect on the part of the mysterious Mr. Larrowe. Then followed a brief period of supreme happiness, lasting from March, till the death of his mother dealt him a tremendous blow, in June. As he tells his sister, all summer he has been

"fighting a constant and lonely battle against depression and discouragement. I think I am winning the battle. Latterly, I have done very little studying . . . felt a constant indisposition to work. Mr. Larrowe's . . . conduct is very enigmatic, to say the least" (Aug. 22d, 1867).

His work in Berlin, during the winter of 1867-8, served to hearten him and, at its close, in March, 1868, he is able to write that he is "very well and happy." But, as summer comes, he is torn by anxiety regarding his future prospects and career.

"I sometimes feel my courage failing me, I am so anxious to be earning something and to be settled in a fixed occupation" (Aug., 1868).

It is fair to infer that the European period was one of acquisition and that, even after the Berlin term, he had not thought through to a consistent standpoint. Later,* we shall have reason to see that, of the teachers with

* See below, pp. $217 \mathrm{f}$. 
whom he worked, Trendelenburg, to whom he refers as "the first philosopher now living in Germany," exerted greatest influence over him. Further, it was only after he had passed beyond Trendelenburg, finding him inadequate, that he achieved an outlook of his own. Finally, it is worthy of note that Morris's article upon his Berlin teacher still remains our most adequate discussion of this strenuous scholar.*

* Cf. The New Englander, Vol. XXXIII., pp. 287-336 (April, 1874). Friedrich Adolf Trendelenburg (1802-72), a pupil of Reinhold, the celebrated Kantian, at Kiel; of G. Herrmann, "the first Greek of his time," at Leipzig; of Hegel, Schleiermacher, Neander, Ritter, Bopp and Steffens, at Berlin; an acute thinker and, no less, a thoroughly equipped scholar; professor of philosophy in the University of Berlin from 1833; member of the Royal Academy from 1846, and secretary, for the section of history of philosophy, from 1847 till his death. "His principal works are, in addition to the edition of Aristotle's De Anima, his Logical Investigations (1840; 2d ed., 1862;3d ed., 1870), his Natural Right (1860; 2d ed., 1868), and his Historical Contributions to Philosophy (Vol. I., 1846, on the History of the Doctrine of the Categories; Vol. II., 1855, Vol. III., 1867, mostly critical articles on ancient and modern philosophers and philosophical systems). Numerous addresses, chiefly delivered in the Academy and relating to questions philosophical, historico-political and aesthetic, are published in his Minor Writings (2 vols., 1870). He also published Elements of the Aristotelian Logic . . . which went through four editions at least, also a volume . . . of elucid. ations of the same, which reached the second edition, and both especially designed for use in the higher schools. . . Trendelenburg's lectures extended over psychology, logic, history of philosophy, ethics, and the philosophy of law. His lecture-room was usually crowded. His genial manners and the simple fitness and felicity of his style and delivery rendered him unusually attractive.... He gained great influence among the higher class of teachers in Prussia and throughout GermanyHis devotion to labor was unflagging, his health always perfectly good until very near the end of his life, his family, social, religious, and political relations agreeable, and his death very widely regretted. . . The characteristic of all Trendelenburg's historical investigations is the scientific objectiveness with which he apprehends and sets forth the historic facts and their substantial import. . . A metaphysical theory is therefore necessary, but not one manufactured at pleasure out of the 
The two years intervening between the return home and the call to Michigan, were the saddest of his life. Three factors combined to cast a deep shadow. His mother's death, the more bitter that he was absent, continued to gnaw at his heart. Miss Denison broke her engagement, alleging that "he had grown so learned and had changed so much in his religious opinions, that she was afraid of him." 'Some expressions he uses, in a very intimate letter (22d June, 1868) to his sisters, Susan and Lucy, warrant the inference that this second blow fell in the early summer of 1868 ; in any case, we know that the lady gave him no chance to right matters by a personal interview. Lastly, to crown all, he could not find permanent work, a grave difficulty, aggravated by the concern (partly in the shape of inability to understand) of his nearest relatives. His father and brother " used to shake their heads sometimes over the apparent futility of an extensive preparation and slow results." Mrs. Cone says:

"I remember very well his depression on his return, for his mother had died, and his lady-love had deserted him. . . . philosopher's a priori consciousness. On the contrary, it must be born of the widest knowledge of the actual methods of the sciences and of the facts of existence as actually established. And it is because English and American philosophy has been so often fragmentary and superficial . . . that, though writing, fundamentally speaking, rather in the spirit of an historian than a propagandist, and acknowledging the influence in the right direction which is exerted by illustrious exceptions among our philosophical writers, we have been influenced by the thought that the further infusion, into our current thought, of something like the grave, comprehensive, universal doctrine of Trendelenburg would, if it could be accomplished, be in the last degree beneficial." Thus is Morris moved to characterize the teacher who left the deepest mark upon him. It is of present interest to remark that the contemporary thinker whom Trendeleburg affected most is Rudolf Eucken, the distinguished Jena professor and Nobel Prizeman. 
Between his father and him there was perhaps not so complete an understanding as Grandfather had of his second son, my father; that was due to George's education, and enlarged religious position, and to the habit, acquired in Germany, of smoking - to Grandfather, smoking was nearly as bad as intemperance."

Later in life, the grim old warrior came to appreciate his strange duckling far more fully.

"The Professorship of Modern Languages at Michigan, which came to him in 1870 , though it was not exactly what he sought, settled him and relieved the family anxiety."

Mrs. Cone says further:

"I remember hearing him play [the organ] in church at Norwich soon after his return ... and to hear him play was considered a treat and something unusual."

In a letter, written from Lausanne, Morris discusses the dubious prospect waiting him at home, and tells his sister, that the best thing he can do is to take whatever may offer. He pursued this course precisely, and fortune smiled upon him. He was lucky enough to become resident tutor in the family of the late Mr. Jesse Seligman, the prominent New York banker. Mr. Albert J. Seligman, who was one of his pupils, has been kind enough to inform me that Morris "came to us in 1868, and remained till 1870, when he left to go to Ann Arbor." Mr. Henry Seligman, another pupil, and his brother, "agree that Mr. Morris was a gentleman very reserved in his nature and undemonstrative, but of the very highest character and with a strong underlying wealth of affection for those whom he cherished. I remember further that he kept in touch with us for some years, and that his letters were always of an affectionate tone."

The Seligman home at this time was in a large house at 2 West Forty-sixth Street. 
Nor was this all. About the time of his return, Morris's favorite teacher at Union Seminary, H. B. Smith, in collaboration with Philip Schaff, the famous Swiss-American church historian, projected a "Theological and Philosophical Library: a Series of TextBooks, Original and Translated, for Colleges and Theological Seminaries." Casting about for an initial work, which would attract attention to the Series and give it immediate reputation, they selected the History of Philosophy, from Thales to the Present Time, by Friedrich Ueberweg, successor of Kant and Herbart at Königsberg. Ueberweg was in close sympathy with Trendelenburg, as his System of Logic and History of Logical Doctrines (3d ed., 1868) shows.* This fact, Morris's relation to Smith and, no less, his mastery of German and of the history of philosophy, brought him an invitation to undertake the translation, which he accepted. The first volume was published on $2 \mathrm{~d}$ December, 1871. A letter from Dr. Schaff, dated 23d February, 1871, states that the final proofs had been received, after revision by Ueberweg; while a long letter from Ueberweg himself, just a month earlier, discusses some alterations and additions. Seeing that the translation entailed work of the most laborious kind, involving an incredible mass of detail, and allowing for the necessary delays caused by exchange of proof overseas, it is altogether likely that Morris began soon after his return to New York, and not later than the early months of 1869. $\dagger$ Burdensome in the extreme as the labour must have been, it stood him in good stead. He 'kept his hand in'; the care bestowed

* English translation (1871), by Thomas M. Lindsay.

† Some remarks in Smith's Life and Work (p. 290) indicate that Morris buckled to the great task so early as October, 1868. 
upon verification, the vigilant additions and the admirable judgment throughout, at once increased and proved a knowledge already unusually wide; with publication, his name became a household word in the universities of the English world.* In short, this labour of love placed the capstone upon his preparation, and certified his thorough scholarship. If he would but come, in order to conform to the rules for 'habilitation,' Königsberg would be glad to confer her doctorate upon him. So Ueberweg wrote. All competent judges have recognized the translation to be an achievement, several have held it up as a model. Without doubt, it was the brightest spot in the two dark years.

* Morris's additions to Ueberweg's German text total some 17,000 words. They are to be found, with the exception of about 1000 words, in vol. II. Professor Dewey wrote (in 1889): "The translating was performed in such a way that excellent judges, German as well as English, have pronounced the translation superior to the original. All the numerous references to Greek and Latin authorities were verified and translated, ambiguities in style and statement were corrected; the bibliographical references were increased from the ready and ample store of the translator; numerous accounts of the more noted contemporary German philosophers were added. The translation is a monument not only to the breadth and accuracy of Professor Morris's scholarship, but to his entire fidelity and thoroughness in executing whatever was committed to him." 


\section{CHAPTER V}

Michigan: The First Period. The Johns Hopkins EPISODE

\section{(1870-81)}

At a meeting of the Board of Regents of the University of Michigan, held on 20th September, 1870, Acting President Frieze presented a recommendation from the Executive Committee, nominating Morris to the chair of Modern Languages and Literature. On the motion of Regent Edmund Carey Walker, of Detroit, a distinguished citizen, a benefactor of the university, and a most influential member of the Board, the recommendation was adopted unanimously. Morris entered upon his new duties forthwith.

The administration of Henry Simmons Frieze (186971), Professor of Latin (1854-89), marked a period of repose and reconstruction in the history of the university which, during its brief existence, had been imperilled by two serious controversies, as well as by no little unwisdom, emanating alike from without and from within. During early days,

"no great name was established and spread abroad by the university; no policy had been settled ... the governing board had no power which could be freely exercised, so that its decisions would stand without appeal."*

Between 1846 and 1851, the fight over the Greek Letter Societies had rent the institution, and led to disruption of the faculty.

* American State Universities, Andrew Ten Brook, p. 214. 
"Good plans had been adopted, and a firm foundation had been laid; but as yet the edifice had not begun to rise. Indeed a positive decline in the number of students at the University had taken place. The first Catalogue, that of 1843-4, gives us the names of fifty-three students. This number was gradually increased until 1848, when the number had reached eighty-nine. Then for the next five years there was a steady and serious decline. In 1852 the number of students in the Department of Literature, Science and the Arts, was only fifty-seven, a smaller number than had been present any year since 1845."*

With the appointment of President Tappan (the first occupant of this office), great changes occurred, particularly in the temper of the university.

"The transformation wrought was real and almost immediate. .... It requires but the merest reference to the names of professors appointed during his administration to show that the University brought together under this policy a galaxy of unusually able men. Boise, Palmer, Winchell, Brünnow, Ford, Frieze, White, Campbell, Walker, Cooley, Wood, Watson, and Armor,such were the assistants whom President Tappan gathered around him. ... The work of the University was immensely extended in breadth and depth." $\dagger$

During this administration, the attendance all but trebled, rising from two hundred and twenty-two to six hundred and fifty-two. The faculty was increased from fourteen to thirty. The arbitrary removal of Dr. Tappan by the Board of Regents, in June, 1863, rocked the institution to its foundations, and it was not till 1864 that his successor, Dr. Erastus O. Haven, knew "whether he was really president or not." $\ddagger$ His adminis-

* Historical Sketch of the University of Michigan, Charles Kendall Adams, p. 15.

$\dagger$ Ibid., pp. 16, 19. Cf. Autobiography of Andrew Dickson White, Vol. I., pp. $276 \mathrm{f}$.

$\ddagger$ Cf. Ten Brook, ibid., pp. 242 f. I take it that the account of the affair, given by Ten Brook, is the best available. He writes plainly 
tration accomplished "the healing of the wounds,"* a considerable feat; although it must be confessed that the alumni of the Tappan decade remained implacable for many years.

Frieze who, in 1844, was a teacher of his immediate successor, Dr. Angell, was persuaded to accept the Acting Presidency upon the resignation of Haven, now head of Northwestern University (1869).

"The two years during which he was the chief executive were marked by important events in the history of the Institution. In 1870 women were admitted to all departments of the University. This step was taken by the Regents rather in deference to public opinion than to the wishes of the Faculties. I think that Professor Frieze, like most of his colleagues, assented to the action of the Regents rather than urged it. . . . Another important step was due altogether to the suggestion of the Acting President. That was the establishment of the so-called diploma relation with the preparatory schools. . . . It was owing to the prompt action of Dr. Frieze . . . that the library of Professor Rau, of Heidelberg, was secured for us. . . . It was during his term of office that the legislature voted the sum of seventy-five thousand dollars for the erection of the main building between the two wings of University Hall, and so established the happy precedent which every subsequent legislature has followed in furnishing liberal means for the erection of needed buildings for the University. The power of Dr. Frieze's active and fertile mind was felt in every department of the Institution. . . . No man since the days of that great leader,

with a bias against Tappan, yet with a desire to do justice. He resented the tendency to attribute everything to Tappan, and to omit reference to all that had been accomplished when he himself held office. (He had been President of Faculty, according to the rotation plan, in 1846-7, and again in 1850-1). He did not sympathise with Tappan's philosophical position, and failed to appreciate his eminence; and he evidently disliked the President's rather overwhelming personality no less than his social ways.

* Cf. Autobiography of Erastus O. Haven, p. 149. 
who gave to the University in so large degree its present form and spirit, Dr. Tappan,* has furnished so many of the ideas which have shaped and enriched its life, as Dr. Frieze." $\dagger$

$\mathrm{He}$ was an admirable musician, and a soul full of childlike faith, "naturally and cheerfully devout." $\ddagger$ Morris was soon drawn to him by their mutual delight in music; they became close friends. There can be little doubt, too, that the example of the older man exerted strong influence in attracting the younger to the Church of his English ancestors.

Nor was it due to these personal relations only, that Morris began his career under happy auspices. He took charge of the Department of Modern Languages at a crisis, and enjoyed a rare opportunity to lay the foundations for a new departure. Mr. Edward Payson Evans, who had taught German since 1863, resigned in 1870; and Professor Adam Knight Spence, who had oversight of French since 1859, left, also in 1870, for the Presidency of Fiske University, Nashville, Tennessee. On Frieze's recommendation, the separate chairs were discontinued, and a single department constituted. Morris was placed in sole command, with a native German and a native Frenchman as assistant professors. The experiment proved successful. Frieze himself records that Morris "soon made these studies respectable rivals of the old course in the Greek and Latin classics.”§ Students

* Cf. Frieze's Memorial Discourse on the Life and Services of Henry Philip Tappan. This should be read alongside Ten Brook's History; for, as Dr. Angell says, it "furnishes the best portraiture ever made of the first President of the University."

$\dagger$ A Memorial Discourse on the Life and Services of Henry Simmons Frieze, James B. Angell, pp. 19, 20, 21, 28, 29.

$\ddagger$ Ibid., p. 34. Cf. Autobiography of Andrew Dickson White, Vol. I., pp. $272 \mathrm{f}$.

§ Michigan Argonaut, Vol. V, p. 70. 
"feel themselves highly favored in having parts of their work in French under Prof. Morris. He fully meets our ideal of the model Professor, his dignified and respectful bearing being quite a contrast to what we found in some of our earlier instructors. The plan of having all questions and answers in French is a good one, and will give one a knowledge of the language which could be acquired in no other way."*

A similar method was pursued in German, and the value of the course in Faust is emphasized, especially for its stimulating literary influence. When Morris resigned the Modern Language chair, universal regret was expressed for the loss of "that admirable teacher and ripe scholar." $\dagger$ During the first year or two, as several alumni of the period have informed me, Morris's extreme reticence, and retiring disposition, seemed to place a bar upon familiar intercourse with students. But, although no one would have dreamed of taking liberties with him at any time, this air of reserve wore off gradually, the transparent honesty of his character serving to chasten pupils, even when it did not fully win upon them.

Then, too, Morris joined the staff at an auspicious time. As we have seen, the university had at length attained a solid basis of success, and was surely, if slowly, enlisting the confidence and support of the State. No less important, it was served by some noteworthy, by several distinguished men, thanks to the standards set by Tappan. Williams, revered as the 'father' of the institution,- he had received the first matriculant,the man who, above all others, had borne the burden and heat of the day, was still professor of physics-the living link with a most significant past. Ford, the

* Chronicle, Vol. VII., p. 164.

† Ibid., Vol. XI., p. 1. 
masterly lecturer on anatomy; Cooley, Campbell, Walker and Kent, the most eminent quartette of legal teachers in the country; Prescott, the pioneer chemist; Moses Coit Tyler, the historian of American literature; and Charles Kendall Adams, the protagonist of seminar instruction, afterwards President of Cornell and Wisconsin successively, were all at work, making reputations for themselves and the university. Confronted with an average so remarkable, it is difficult to select. But, thanks to Dr. Angell, Professor Isaac N. Demmon and others, whose memories run back to this epoch, I think I am correct when I say that the greatest influence was wielded by Frieze; Olney, professor of mathematics; Watson, professor of astronomy; and Winchell, professor of geology. Cocker, who received the professorship of Intellectual and Moral Philosophy in 1869, was destined to replace Winchell in this foremost group after 1872, when Winchell accepted the Chancellorship of Syracuse University. Within the institution, especially in the faculty, Frieze and Olney exerted most leverage. Watson, a man of genius, although a persona non grata with some of his colleagues, achieved an international reputation, became a founder of the American science, and carried the fame of the university everywhere; while Winchell's power of public speech, like that of Cocker later, gained a unique position for them in the eye of the immediate public. Sectarian rivalries, a bane of the university from of old, had been laid or surmounted to a considerable extent. Anglicans were gratified by the leadership of Frieze, Baptists by that of Olney; while Methodists, although they had lost their former primacy, could rest well content with the prominence of Winchell and Cocker. The professional 
schools counted influential adherents of the Presbyterian and Congregational denominations. Thus, all things considered, Morris arrived upon the scene at a psychological moment, and-the acceptance of the Presidency by Dr. Angell was less than six months off.

The recollections of colleagues and pupils agree that, for some years, Morris took little, if any, part in the general affairs of the university. This conclusion is supported by the files of the academic and city press, which I have consulted carefully. It would be altogether natural to attribute his seclusion to constitutional reticence. But, thanks to Dr. Angell, in whose family circle Morris soon became a familiar, we know that there was another, and more potent, reason. The truth is that he felt ill at ease intellectually and spiritually. He had drifted very far from his youthful moorings, and had found no anchorage in the open sea. The mind frayed the body too, and he was a martyr to dyspepsia. I cannot discover that he unbosomed himself to anyone except Mrs. Angell. He seems to have talked to her with an intimacy extremely rare on his part. Unfortunately, I never had occasion to ask her to give her impressions. Notwithstanding, one can piece together a portion of the story at least.

Whenever, during that period, men were beset by doubt, they found a large body of congenial literature convenient to hand. Curiously enough, the evolutionist party, driven by the non possumus of the theological opposition, threw itself into the arms of a philosophy which, being temperamentally unhistorical, was at fundamental odds with the rising hypothesis. Hume and Voltaire, along with other avatars of eighteenth century Rationalism, gained a new, if paradoxical, lease 
of life. Their later issue, Mill, Spencer and Huxley, furnished a popular and, be it confessed, jejune philosophy, that squared itself expeditiously with many of the crude or uncriticized inferences bred of the scientific movement, and gained easy applause by advertising a break with 'mediævalism' unaware that this was tantamount to a repudiation of the historical problems of philosophy as treated by the major thinkers, from Plato down. Agnosticism saturated the air, and there was much loose talk concerning 'correctness of observation' and 'consistency of inference,' coupled with abundant ignorance about the possible objects of philosophical 'observation' and the available methods of philosophical inference. The triumphant scientist beat the theologian at his own game - of dogmatism. Hence, studies quite subsidiary or merely preliminary to a valid philosophy, came to be mistaken for serious philosophical investigations. As a consequence, fundamental problems, inseparable from metaphysical Wissenschaft, were postponed or, what was far more dangerous, conventionalized. It is apposite to note that, by the early seventies, this tendency had so far crystallized in the United States as to support an organ of its own. The importance of The Popular Science Monthly (1872) lies in the fact that it did find a public, and did meet a call, despite the point, well taken by Spencer himself.

"I have often had qualms as to the policy of making the Monthly a propagandist organ to so large an extent."**

Small wonder, then, that, unable

"out of Senseless Nothing to provoke

A Conscious Something,"

* Life and Letters of Herbert Spencer, David Duncan, Vol. I., p. 231 (American ed.). The italics are mine. 
Morris, set amidst this movement,- thoroughly sure of itself, he as thoroughly uncertain,--should have swung far in the direction of rationalistic agnosticism, and have endured the pangs of one forced to say of his former sufficing faith,

"Beside whose grave I pace forevermore, Like desolation on a shipwrecked shore."

Moreover, the influence of Trendelenburg led him in the same direction.

"The exclusively critical task of deciding as to the powers and limits of the human intellect and the nature of scientific knowledge was taken up as a definite problem, . . . partly as a continuation and confirmation of Kant's views, partly also in opposition to them. The solution of this problem was very much assisted and influenced by two independent lines of research. The first of these was the analysis of the methods of science, of which John Stuart Mill was the great representative; the second was the revival of Aristotelian studies, in which Trendelenburg of Berlin was the principal leader. . . .'From that time the religious influence loses its tempering and controlling effect."*

But it is to be recalled also, that Morris's German studies prevented him from acceptance of facile empiricism. He knew too much. At this period, then, he was thumbing Voltaire-and consuming his own smoke. The preparatory years still dragged their long, slow course, to the end that another and wiser doctrine might be won, destined to replace simple assent and to transcend sophisticated doubt by annealed insight, the highest species of faith.

No letters or other documents from Morris's own pen survive, to bear witness to his mental struggle.

* A History of European Thought in the Nineteenth Century, John Theodore Merz, Vol. III., pp. 125, 159. 
Dr. Angell's recollections are quite definite, however; and the state of affairs was suspected, if no more, in quarters far removed from Ann Arbor. Old friends in the East were well aware of Morris's desire for transfer to a philosophical chair, and stood ready to second his wishes. Thanks to the good offices of Professor Henry B. Smith, he was under consideration by the authorities of Bowdoin College for the chair of philosophy and, apparently, the chaplaincy. And the following letter, from Smith, throws some light upon the situation.

"New YoRK, Oct. 16th, 1872.

"My dear Prof. Morris, I think it only right that you should see the enclosed letter of Presd. Chamberlain, before I answer it finally. He has been all along strongly inclined to you, and would be a good friend.

"You must, of course, decide the matter. I think they would agree that you should teach and not preach. $I$ should have said, that while you might be wavering on some points of criticism, etc., - and as to the strictest theory of inspiration: yet, that I believed you were planted on the main principles of the Christian system (as distinguished from materialism, pantheism -or any form of infidelity): and, that your philosophical teachings would be in harmony with-in fact reflecting-theism and Christianity.

"Do not decide too hastily (let me ask you). Many men now-a-days must pass through doubt, and conflict. As far as the present offer (post) is concerned, I think the only essential point is this,-Whether, on the whole, you feel yourself to be grounded in the spiritual principles of the Christian faith, as compared and contrasted with any other system.

"Prof. Botta's Appendix is in type; Presd. Porter's has not arrived.

"Ever truly Yrs.

"Henry B. Sмith."

The enclosure referred to reads thus: 
"My dear Professor Smith,

"Brunswick,

"Oct. 9th, 1872

"Some of our watchmen on the walls think Professor Morris may have tendencies to Rationalism, or at all events may not be in strict accordance with the "orthodox" faith.

"I regard the ehair of Philosophy as of more importance than the Presidency. We need a strong, sound man.

"May I venture to ask for a word in confidence as to Prof. Morris. He has written me withdrawing his name; but I never supposed he knew of our thoughts towards him. I have not yet answered his letter, and hope to hear such satisfactory accounts of him in all respects, that I can insist upon retaining him.

"With thanks for your former kindness, I am,

"very truly,

"Your friend and servt., "Joshua L. Chamberlain."

Writing on 27 th December, 1872, to his friend, Madame Joël, of Lausanne,-a letter which, by the way, attests his facile mastery of French,-Morris records his "great preoccupation" with the Ueberweg translation, and adds:

"I have been specially troubled about the question of a change of position. They have offered me a place as professor of Philosophy in a College in the State of Maine. It is uncertain as yet whether I shall accept. But you can well understand that this has given me much thought."

Characteristically, too, he relates that he had just attended a concert by Rubinstein, in Detroit,- “"a veritable revelation to me; I never heard anything like it."

The refusal of the call to Bowdoin was made public in the middle of January, 1873.

Meanwhile, the translation of Ueberweg's History of Philosophy cannot but have absorbed him. The first volume was published in America, in 1871, in 
Great Britain, in 1872; the second followed in 1873, in both countries. The successful completion of this most exacting labour made his name familiar in academic circles, affected his future career, and, as will appear presently, his relations nearer home. At the time it was the best work of the kind that had been accomplished. As one critic says:

"Morris shows marked distinction in this line for so young a man."

And Frieze, himself a master of languages, quick to recognize merit, wrote:

"The series of great works . . . at that time being published under the supervision of Professor Schaff, included in the plan a translation of Ueberweg's History of Philosophy. Mr. Morris was at once engaged to undertake the translation; and certainly no greater proof of confidence in his attainments could have been given; for the perfect translation of such a work presupposes a knowledge of the whole field of philosophical reasoning, and an absolute command of the phraseology of its literature, both in the original and in the language of the translation. When the translation of Professor Morris has become so widely known, I need not say that it has abundantly proved his admirable fitness for the task that was assigned to him."**

The old love for music must also have exerted a healing charm; and it is not surprising that his early appearances in public were as a performer. The local Ladies' Library Association had been founded recently, and concerts were one means adopted to raise a book fund. On several occasions, between 1873 and 1875, we find Morris playing with Frieze at such recitals. He also presided at the instrument, when the new organ of the Congregational church was dedicated in the spring of 1876. On the other hand, it was not till 1874, three

* Michigan Argonaut, Vol. V., pp. 69-70. 
and a half years after his appointment to his chair, that he could persuade himself to take part in the series of addresses, of a religious nature, given by members of the Faculty before the whole student body. Moreover, he was very sparing of such appearances; between February, 1874, and May, 1882, he spoke but thrice; and Dr. Angell had to exert all his arts to persuade him to undertake even these. Devout by nature and nurture, filled with a strong sense of personal responsibility, he, no doubt, bethought him of the precept, "Physician, heal thyself." But, thanks to deepening philosophical grasp, to the courage which 'goes out into the Infinite alone' and, in some part, to the 'walk and conversation' of friends,-Frieze and Mrs. Angell particularly,- -he fought the battle through step by step, gaining at length a reasonable faith, whereon his feet stood firmly planted to his life's end. On the Second Sunday in Lent (9th March), 1873, he received Confirmation and, ever after, took comfort and found rest in the historic doctrine and orderly worship of the Church of his English forefathers.

As the years sped, his position in the university was not without its anomalies. He had accepted the chair of Modern Languages faute de mieux: in view of his training and vital interests, it was a pis aller more or less. The academic world understood the situation, especially after the publication of the Ueberweg version. In 1872, as we saw, Morris received a call to teach philosophy in Bowdoin College; similar offers were made him by the University of California, and the City College of New York, in 1878; by the University of Wisconsin, in 1879. Since the ejection of Tappan, who had conferred high distinction upon the chair, the history of the 
professorship of philosophy had been somewhat unfortunate.

"For several years after President Tappan's withdrawal, the chair was incompetently filled by a man whom, tradition says, a certain church became tired of, and palmed off on the University, because it could not get rid of him in any other way. Be that as it may, this gentlemen finally resigned, and for two years Dr. Haven occupied this chair . . . besides attending to his other duties. Under such a condition of affairs, it is no wonder that the seniors found themselves gentlemen of leisure."*

Moreover, one year before Morris was called to the professorship of Modern Languages, the philosophical chair had been filled, on the resignation of Haven, by an appointee who, while a persona grata with many who were representative of the constituency of the institution at that time, thanks to his great natural gifts as a preacher, was, perhaps for this very reason, thoroughly characteristic of the period in the weightier matters of technical preparation and expert competence. Older students had sensed the need, and stated it in good set terms. "We want a man who has made this study his specialty, and can infuse life into the dry bones of philosophical discussion." $\dagger$ They got a real personality, but not a specialist.

In almost every respect, the contrast between Morris and Cocker could not have been greater. Behind the one lay the entire New England tradition of passion for education. Bred in this, he was master of his tools; "the only languages that Philosophy has ever learned to speak"-Greek and German-were familiar to him. $\mathrm{He}$ was at home with Plato and Aristotle, with Kant

*Chronicle, Vol. I., p. 25. Cf. Ten Brook's History, pp. 256 f.

$\dagger$ Chronicle, Vol. I., p. 25. 
and Hegel, in the primary sources. In like manner, he had direct access to Lucretius, Cicero and Seneca, among the ancients, to Descartes, Spinoza and Leibniz, among the moderns. Cocker, on the contrary, born in Yorkshire (1821), at a time when English dissenters had little part in such national education as there was then, enjoyed no schooling after his thirteenth year, and had gone into business as a boy. He says:

"I was accountant in the largest house [woollen] in England for twelve years [i. e., from his eighteenth till his twenty-ninth year], and then went to Australia, and was accountant for a large shipping firm [mining supplies] there, and their personal agent."*

Broken financially by the panic of 1856 , he salved enough from the ruin to buy a small vessel, with which he traded in the Fiji Islands. Wrecked on the island of Tonga, he was rescued, when in imminent danger from cannibals, and brought to Sydney, New South Wales, whence he made his way-in dire straits - to the United States and to Adrian, Michigan, where he had a friend in the Methodist ministry. Having been a lay exhorter as a youth in England, he found it easy to obtain a pulpit, and began life over again, in charge of the Methodist church at Palmyra, Michigan. His genuine gifts as a preacher were soon noised abroad, and he was advanced to important pastorates in the Detroit Conference, where his fervid eloquence made him a power. During these years, immensely to his credit, he educated himself as best he could and, as happened so often in these days, found himself transferred from the pulpit to the philosophical chair. His public gifts,-there

* Report of the Joint Committee of the Michigan Legislature of 1877 on Alleged Defalcations etc., p. 472. 
are those still alive who judge him the finest preacher they ever heard,--his earnestness, warm-heartedness and geniality, backed by his varied experiences, enabled him to adjust himself to the contemporary social environment with the utmost success. Dr. Angell says: "he was like a father to every student," and "a great vital force in the moral life." With the students, he was "king of them all"-this by comparison with other professors. They "took an uplift" away from his class-room, notwithstanding his lack of system. The local press records that, on the occasion of his departure for a European tour, one thousand students, a brass band at their head, escorted him to the station! These qualities, coupled with a certain native acuteness, atoned for very inadequate preparation, and elicited applause from the average man. On the other hand, his mind being strongly of the intuitive or imaginative cast, Cocker could not sift evidence, ${ }^{*}$ and exercised little influence with his colleagues. He knew no language except English. Thus, although he filled a distinct place, with credit to himself, with benefit to his pupils, and to the university in some of its relations to the immediate public, he could not but be aware of his professional inferiority to Morris. Equally, this unavoidable situation could not but place a bar upon Morris's hopes of transference to the Philosophical Department. The very different gifts and, consequently, spheres, of the two men, assisted, undoubtedly, by Morris's sweet disposition, softened whatever incompatibility there

* Cf. e. g., Report of Joint Committee of the Michigan Legislature of 1877 on Alleged Defalcations, etc., pp. $470 \mathrm{f}$., or the naive attitude towards the Timaeus of Plato and to the Theistic Proofs, in Christianity and Greek Philosophy, pp. 335 f., 487 f. 
might have been, even although one notable member of the staff was in the habit of exalting Morris at the expense of his colleague. The ill-starred dispute over the finances of the chemical laboratory,* which burst in 1875, and continued for some years, becoming a lively issue in State politics, and dividing the university into factions, from the governing Board down, did not help matters. Cocker made open cause with one side; Morris, although never a participant, was understood to sympathize with the other. Intense feeling was generated, and exceeding bitter asperities prevailed. Inevitably, questions of appointment, promotion and the like, felt the effect. Indeed, it was little short of providential that irremediable blunders were not perpetrated.

In these circumstances, Morris certainly welcomed an invitation, which he received in December, 1877, to become Lecturer on History of Philosophy and Ethics in Johns Hopkins University. He entered upon the duties in January, 1878, and thus began a relationship that lasted for seven years. At first, philosophy being undeveloped, class-room instruction had not been organized, and Morris took part only in the Hopkins Hall Lectures, $\uparrow$ which the official Circulars describe as follows:

"These courses are academic lectures, designed primarily for the members of the University, and supplementary to the regular class-room work of the students. As the members of the University rarely require the entire room, the Trustees have great pleasure in inviting other persons, not connected with the University, to attend. As these lectures are not intended for popular entertainment, but for the instruction of students,

* Cf. The Reminiscences of James Burrill Angell, pp. $246 \mathrm{f}$.

† Cf. The Life of Daniel Coit Gilman, Fabian Franklin, p. 242. 
those persons first receive tickets . . . who are known to be especially interested in a particular course. Preference is thus given, according to the character of the course, to teachers in other institutions, public and private; students of medicine, law, etc. . . . The hall is full when 200 hearers are present; it is uncomfortable if more are admitted. . . . To give the lectures elsewhere would alter their character as a part of the ordinary academic work of the University."

Thus, in January, 1878, Morris gave a course of twenty lectures on History of Philosophy, with an average attendance of one hundred and twenty-four. It is interesting to note that duties as an examiner were assigned to him forthwith, and that, in this year, he acted as examiner of Professor Josiah Royce, on the major subject (History of Philosophy), and of Professor Ernest G. Sihler, on the minor subject (Ancient Philosophy), for the degree of Doctor of Philosophy. In January, 1879, he gave a second course of Hopkins Hall lectures, entitled Topics Historical and Practical in Ethics, which "attracted wide attention."

In 1878 and 1879, the Johns Hopkins work had demanded his presence during the month of January alone and, as this synchronized with part of the Christmas recess and with the interval between semesters at Ann Arbor, his teaching there was not broken seriously. But the impetus given and the interest aroused by him in Baltimore, led the Trustees to make more adequate provision for the subject. Morris was thus confronted with the question, not simply of his relation to the University of Michigan, but of abandoning modern languages finally, to give his entire time to philosophy. Two letters, one personal, the other official, of date, February, 1879, from President Gilman, explain the circumstances and, if one read between the lines, shed 
light upon Morris's aspirations and fundamental interests. In the private communication, Dr. Gilman says:

"I need hardly add, after all our conversations, to the enclosed official letter. The action was cordial and, I believe, in exact accordance with our understanding. I do not wonder that you relinquish the City College suggestions. I hope that in the East or West you will find some opening to enable you to bring out your philosophical studies,--and if I see any chance to say a good word you may be sure that I shall speak gladly."

The official notice was this:

"Our Trustees yesterday [3d February], voted to invite you to lecture before the Johns Hopkins University on the History of Philosophy and on Ethics, for the next three years, at an annual salary of $\$ 1500$, with this understanding, that your residence among us would extend through three months annually. I sincerely hope that we may have the benefit of your coöperation."

As a result, Morris placed his resignation of the chair of Modern Languages in the hands of the Michigan Regents in June, 1879. This was accepted with deep regret, and a laudatory appreciation of his services spread upon the minutes. His pupil and friend, Edward L. Walter, whose tragic death on the French steamer, La Bourgoyne, lost in collision on 4th July, 1898, proved a deplorable loss to the university, was appointed to fill the vacancy. Walter, who was in Europe at the time, desired to prolong his stay, and, to accomodate him, Morris performed the duties of his former chair during the first semester of the academic year 1879-80. In the "second-half year," he entered upon his enlarged activities at Baltimore, in conjunction with Mr. Allan Marquand, afterwards of Princeton University, who had charge of the courses in Logic. Accordingly, during the early months of 1880 , he taught three classes, as 
follows:-History of British Philosophy, thrice weekly: German Esthetics, and Ethics, each once weekly. $\mathrm{He}$ also delivered a public course of twelve lectures, published in the following autumn, in his well-known book, British Thought and Thinkers.

In a Christmas letter (1879) to Madame Joël, Morris says:

"I am soon to abandon my position in the University of Michigan, in order to give myself entirely to philosophy. . . . I do not know as yet whether I shall remove to Baltimore permanently-I expect so."

Fate willed otherwise. Throughout this period, he maintained his house in Ann Arbor which, as a matter of fact, continued to be his headquarters, so that his Johns Hopkins visits were visits from home. His success at Baltimore, his position of considerable and growing authority in philosophical circles, and his proven capacity as a teacher, warned the Michigan administration that he was too valuable a man by far to lose. So Frieze, who again occupied the Acting Presidency, during the absence of Dr. Angell on the Chinese diplomatic mission, came to the rescue. $\mathrm{He}$ had great influence with Cocker, who was now not in the best of health, and needed assistance. As a result of his judicious manipulation, Morris was appointed to a new professorship-Ethics, History of Philosophy and Logic -on 30th June, 1881; the arrangement being, that he was to teach at Michigan one half year, at Johns Hopkins the other. This apt solution saved Morris for Michigan, and yet made it clear that the premier chair of Philosophy still belonged to Cocker, who informed his friend, former Senator Campbell, that he welcomed the plan. At the same time, Michigan conferred her Doctorate in Philosophy upon Morris, in recognition of his eminence. 


\section{In his Report for 1881, President Gilman writes:}

"It has been from no want of interest in philosophical studies, that we have been delayed in making permanent arrangements in regard to them: but the scheme of lectures as now arranged offers some noteworthy opportunities. Professor George S. Morris, who has spent a portion of every year among us since 1878 , continues to lecture upon history of philosophy and on ethics. The fruit of his call to a congenial work may be seen not only in his own published volumes, but also in the series of philosophical studies which he is editing, beginning with his own study of Kant's Kritik, which was given to his students in this university in the course of last winter. Mr. Charles S. Pierce, who has been for a long period a close student of the processes employed in various branches of physical investigation, and who is a proficient in more than one department of science, now offers to our students instruction in logic, or the method of methods, particularly for the benefit of those who are expecting to be engaged in investigation and who need fundamental guidance in the principles which underlie the discovery of scientific truths. . . . . Professor G. Stanley Hall, Ph.D., will hereafter direct our students in psychology, a service for which he has become fitted by his historical studies, by prolonged work in the laboratories of Leipsic and Berlin, and by varied experiences as a lecturer in Harvard, Williams, and other colleges. Dr. Hall is desirous of awakening the attention of our students, particularly of those who expect to become teachers, to the importance of scientific pedagogics, and will doubtless offer some definite instruction in this subject."*

The absence of Morris from the Michigan staff thus covered the academic year 1880-81. At this, he was resident in Ann Arbor during the greater part of the time, engaged busily in study and writing. The total period of his residence in Baltimore, during eight years, was less than eighteen months.

One most important event, of much moment for his

* Pp. 47-8. 
future, remains to be recorded. On 29th June, 1876, he was married, at Ann Arbor, to Miss Victoria Celle, daughter of Charles Antoine Celle and Maria (Rogers) Celle, of New York City. Miss Celle was an old friend of the family of Professor Edward Swift Dunster, of the Michigan Medical Faculty, with whom Morris also was on terms of intimacy. In due time, a son and a daughter were born to them, and a home life, singularly bright and happy, grew up. Morris took intense delight in his wife and children, and his untimely death was a peculiarly irreparable loss to them. The only son, once a pupil of my own, is now a well-known physician, who has occupied positions on the teaching staff of Johns Hopkins University and of the Washington University of St. Louis, and is now Frederick Forchheimer Professor of Medicine in the Medical School of the University of Cincinnati which, thanks to its magnificent hospital, enjoys such fair prospects. 


\section{CHAPTER VI}

\section{WithdRawal from Johns Hopkins. Michigan: The Second Period}

(1881-89)

Morris was now forty years of age, his powers verging upon maturity. His occasional writings, such as the classical article on Trendelenburg (1874), the London Victoria Institute lecture On Final Cause as a Principle of Cognition (1875), The Philosophy of Art (1876), and the account of Spinoza's system (1877), had made him further known to specialists, while his first book, British Thought and Thinkers (1880), had gained him a wider audience. The stimulus of the "congenial work" at Johns Hopkins was seen in the admirable account of Kant's Transcendental Deduction of the Categories (1881), and in the Series of German Philosophical Classics for English Readers, which he originated, edited, and launched with his Critical Exposition of Kant's Critique of Pure Reason (1882). He had been selected by the editors of the American Supplement to the Encyclopedia Britannica to contribute certain articles to their first volume.

In February and March, 1881, he gave a comprehensive course of Hopkins Hall lectures on the History of Philosophy in Germany from Kant to Hegel, as follows: Comparative Biography of Leibniz, Kant, Fichte, Schelling and Hegel; the Theory of Knowledge, as developed by these philosophers; the Theory of Being, comparative view of the doctrines of the same philosophers; Theory of Nature, comparative view; Theory 
of Man, comparative view; and Philosophy in German Literature. He also taught regular classes in the History of Philosophy, and Ethics, and a seminary in Aristotle's Ethics. He was active in the meetings of the Metaphysical Club, of which he became president, where we meet, as contributors, some names destined to become notable afterwards,-E. B. Wilson, W. T. Sedgwick, Christine Ladd, Josiah Royce, B. I. Gilman, C. R. Lanman and G. Stanley Hall, among others. Classes in Greek philosophy, and Ethics followed, in 1882, together with a course on Kant's Critique of Pure Reason, published soon afterwards, in the German Philosophical Classics. Major courses were now offered, in Logic and Psychology respectively, by Messrs. C. S. Pierce and G. Stanley Hall, while undergraduate instruction was given by Mr. B. E. Smith, from Amherst College. The programme for the academic year, beginning September, 1882, lists Morris for the following: History of Philosophy in Great Britain; Philosophical Seminary, for the study of selected texts, ancient and modern, relating to the science of knowledge; Ethics, with especial reference to F. H. Bradley's Ethical Studies; and Hegel's Philosophy of History. He is also advertised to offer a course of eight public lectures, in January, 1883, The Philosophy of Religion in its Relation to Christianity. This proved to be a repetition of the Ely Lectures. Much to his gratification, Morris had been recalled to old scenes of student days, in Union Theological Seminary, to succeed J. W. Dawson, James McCosh, A. P. Peabody and Henry Calderwood, as lecturer on the Ely Foundation. The result was his principal pronouncement on the relations between philosophy and religion-Philosophy and Christianity (1883). 
Continuing his Johns Hopkins service, in the first semester of 1883-4 he gave courses in History of German Philosophy and in general History of Philosophy, as well as seminar instruction in Spinoza's Ethics. One year later, he offered courses in History of Philosophy in Greece, in Ethics, and a new course, on a subject now engaging his attention, Philosophy of the State. He also delivered four Hopkins Hall lectures on the Philosophy of Social Relations.

The death of Cocker (April, 1883) having entirely altered the situation at Michigan, Morris found it impracticable to continue his labours at Baltimore, and withdrew at the end of the first semester of 1884-5, not, however, before he had gathered a remarkable band of students, among whom we find Professors John Dewey, Joseph Jastrow, Henry L. Osborn, Benjamin C. Burt, W. H. Howell, Allan Marquand, Richard C. Burton and Fred M. Taylor. Most fittingly, his final appearance in Baltimore was at the meeting of the Metaphysical Club, on 27th January, 1885, when he read a paper entitled The Method of Philosophy. There is evidence to the effect that, with his resignation, Philosophy at once dropped to a secondary position in Johns Hopkins, where it remained for many years.

There can be little doubt that, when Morris was appointed to the Lectureship in Ethics at Johns Hopkins (1877), he anticipated, and was led to believe, that in due time he would be placed in full charge of the philosophical work there as professor. Events so conspired that this was not to be. As a consequence, the Baltimore institution lost a unique opportunity to assume in philosophy the leadership which it acquired in some other departments; in all probability, also, philosophical 
instruction in the United States was retarded. On the other hand, Harvard was left free to seize the primacy in the East, while at Michigan, thanks to Morris, Philosophy began to gain the unusual influence exerted by it ever since. It is exceedingly difficult now to adjudicate fairly upon the pros and cons as they eventuated at Johns Hopkins, although the die was cast ere financial stress overtook the university. I can only attempt an interpretation of what seems to me to have been a serious blunder in academic perspective, if nothing more.

Dr. Angell has told me often that Morris was disappointed by the lukewarmness of the Baltimore administration towards Philosophy. The failure to lend it the support and recognition, bestowed so freely upon philology and the laboratory sciences, hurt him. Other authoritative sources of information serve to confirm this judgment.* Political, industrial, theological and

* It is fair to say that one incident appears to traverse this unanimity. In September and October, 1880, Flint, then professor of Divinity in the University of Edinburgh, whither he had been called, early in 1876, from the chair of Moral Philosophy in the University of St. Andrews, delivered the Stone Lectures at Princeton Theological Seminary. According to his biographer, the impression made was so "deep," that, "in 1881, the authorities of John [sic] Hopkins University offered him the Professorship of Philosophy in that Institution, and when they failed to induce him to accept it, they asked him to deliver a course of lectures on some philosophical subject, for which they were prepared to give a thousand dollars" (The Life of Robert Flint, Donald Macmillan, pp. 363-4). I take it that this is correct, although during most confidential and decisive communications with Flint at the time of my call to Michigan, he never so much as mentioned the matter (cf. Ibid. pp. 499 f.)! The proposal consorts with Dr. Angell's idea, that Gilman desired above all things to secure a 'safe' man. And it is in itself a farther commentary upon his blindness to the tendencies of the 'scientific' anti-philosophy then influential at Johns Hopkins, no less then upon his inability to sense the real inwardness of Morris's standpoint. 
social interests had been, and were, destined to deter Philosophy from continuous critical treatment of fundamental problems in the United States, and subsidiary questions, as philosophers account them, forged to the front. In the same way, the zeal for educational methodism led many to suppose that Philosophy consisted in that special analysis of common sense which leads straight to an empirical psychology. Significantly enough, then, official records of the university indicate that after 1885, Philosophy became secondary to Psychology and 'Pedagogics' - early signs of a tendency that has since wrought untold havoc upon the advance of philosophical Wissenschaft in this country. Significantly enough, too, President Gilman records, in his Report for 1886 :

"For several years a metaphysical society was maintained, part of the time under the leadership of Mr. C. S. Peirce, a part of the time under that of Professor G. S. Morris,-but the association is no longer maintained."*

After summarizing Morris's work, the same Report proceeds to show-quite unconsciously, of coursehow subordinate Philosophy had become; the idea being, I infer, that it did not offer opportunities for 'original research! $†$ Fortunately, the lapse of time enables us to see that we are not dealing here with institutions or individuals, but with a world-wide movement.

I have given, in chapter viii of Flint's Life, a full account of his philosophical teaching. It shows how 'safe' he was. Gilman's reasons for seeking 'safety' may be gathered from the following: The Launching of a University and Other Papers (1906), p. 23; University Problems in the United States (1898), pp. 39, f. 56.

* P. 27.

†Pp. 46 f. Cf. Report for 1888, pp. 89 f. It was resolved to "discontinue the existing Metaphysical Club" on 18th Nov., 1884; Cf. Johns Hopkins University Circulars, Vol. IV., No. 35, p. 28. 
Johns Hopkins University and its president in their way, Morris in his, and many others were caught in one of those streams of tendency that are no respecters of persons. Science, at the flood of the Darwinian theory, was sweeping everything before it, and philosophy had become tolerable only as an introduction to scientific method. It was unlucky for Morris, at the moment, that systematic philosophy - the only philosophy worth the name wissenschaftlich-had made but little impression in the United States, and that, as a result, his critical attitude towards the premature generalizations associated with science was taken for a reaction to Protestant dogmatics; he was supposed to be essentially inimical to scientific research, not merely in physical but in humanistic affairs. Naturalists did not like his 'transcendentalism,' historians and economists deemed him a 'romantic.' Original research was taken to imply measurement and numbering of 'objective' things; the extensive preliminary requirements for successful advance in philosophy were not provided or, at least, not emphasized and, as is altogether likely, had not been understood. The things unseen and eternal seek personalities to their hire, rather than methods and machines; hence they tend to prefer conditions hard to meet. In any case, they escape the conventions, and especially the rapid results, possible with things seen and temporal. The danger was already afoot, that search, the routine of the decent famulus, should be mistaken for research, the creation of a real intellect, thoroughly alive. Hence the expert, whose instruments record the movements of the vocal muscles of the performers in an opera, was prompted to look with more or less disdain upon the man who had devel- 
oped the personal insight to penetrate the spiritual value of the work.* Happily, this mood of confidence has passed; we now begin to suspect that 'infusorial bubbles' are-bubbles. Ballast, immensely useful in its way, cannot be called cargo.

Again, the internal evidence furnished by Gilman's Life and writings serves to show that, alike by experience and temperament, he was antipathetic to the Idealism for which Morris now stood. From the outset of his career he had been interested in scientific and technical education: $\dagger$ he occupied the professorship of Physical and Political Geography in the Sheffield Scientific School of Yale University. + He soon became absorbed in administrative questions. $\S \mathrm{He}$ was "a man of surpassing talent for organization . . . of incessant industry and persistent acquirement," $\|$ without a trace of the thinker in the philosophical sense. Expressions used by him in public addresses $\uparrow$ and his policy when Johns Hopkins was founded,** warrant the inference that he conceived of philosophy as ethics, and that he regarded it primarily as a collegiate or disciplinary, not as a university or research subject. It was little more than an advisable or 'character-forming' preliminary. When he surmounted this view, it was to emphasize experimental psychology, $\dagger \dagger$ or logic, not as a pure science

* Dr. G. Stanley Hall pointed this out many years ago; ef. Aspects of German Culture, pp. $301 \mathrm{f}$.

† Cf. Life, F. Franklin, p. 41.

$\ddagger$ Ibid., pp. 57 f., 73.

\& Ibid., pp. 89 f., 95 f., 179 f., 267 f.

|l Ibid., pp. 180, cf. 213.

I Johns Hopkins University, Celebration of the 25th Anniversary, p. 27; University Problems in the United States, pp. 18, 21 f., 58 f., 213 f., 273 f., 296 f., 217 f.

** Cf. Life, pp. 217 f.; The Launching of a University, pp. $52 \mathrm{f}$.

†† Twenty-fifth Anniversary, p. 31; University Problems, pp. $59 \mathrm{f}$. 
however, but as an instrument to teach the physician how to reason!* One who could declare so late as 1885 , "I do not know whether philosophy is 'on a return to Kant' or to common sense," could hardly be blamed if, on organizing a university, he permitted the whole of philosophy - the systematic rethinking of universal first principles - to disappear in its parts. $\dagger$ His stress is invariably upon natural science and philology $\ddagger$ 'Pedagogics' he could descry, with an eye to administration; deduction of the categories left him helpless and, perhaps, as a citizen "of an enlightened Christian city,"§ suspicious.

On the other hand, thanks to recent intellectual experiences with Agnosticism, Morris was in strong reaction against the 'realistic' tendencies that dominated the university alike in its scientific and humanistic studies. He literally abominated the current 'philosophy of science'; and the young lions of history, politics and economics, who followed an occasional seminar with him, little relished his undisguised conviction that their pet themes were, in large measure, preliminary to something incomparably more significant-the interpretation of seminal ideas in their historical manifestation. Thus, like his namesake, C. D'U. Morris, one of the first Johns Hopkins faculty, who taught college classics and the beggarly elements of philosophy, "the times seemed to be against him." "| Other ideals and interests held the field, and attracted the administ-

* University Problems, p. 231.

† Cf. Life, pp. 215 f.; University Problems, pp. 21 f.

$\ddagger$ Cf. The Launching of a University, pp. 19, $218 \mathrm{f}$., $243 \mathrm{f}$.; Twenty-fifth Anniversary, pp. 34 f., 41 f., 129 f.

$\S$ University Problems, p. 36.

\| The Launching of a University, p. 52. 
rative eye. Such sporadic philosophy as there was savoured of Neo-Kantianism,* and of this phenomenon little was known and less understood technically in Baltimore. It was thus almost inevitable that the 'research' appeal of experimental psychology, and the utilitarian trend of 'pedagogics' should supplant the theoretical interest of philosophical Wissenschaft. The paradox is that, in this the home, as all conceived it, of pure science, the purest of pure sciences could not find a place where to lay its head-and this without blameworthiness on the part of any one.

Dr. Benjamin C. Burt, known for his excellent histories of philosophy, favoured me in his last days $\dagger$ with those comments upọn the situation. When Morris was at Johns Hopkins

"The general atmosphere did not, to me, seem very hospitable towards philosophy. The 'scientific' spirit was too strong. The classes in philosophy were not large when I was there, in 1880-81; and, in fact, the departure had not yet been fairly recognized. Indeed, I doubt if philosophy has ever obtained a real foothold at J. H. U. to this day. $\ddagger$ However, Professor Morris had admirers and friends in the J. H. U. faculty, I believe. He certainly was fond of meeting others at the J. H. U. Club, where they could smoke together,- - he was no prig, gentle and courteous though he was always."

In this connection, my friend, President G. Stanley Hall, has been kind enough to communicate a very frank letter, which says much, and intimates more.

"I felt a great and, no doubt, extravagant, affection and admiration for him [Morris]. I remember very well, in a board-

* As was shown later by W. K. Brooks in his The Foundations of Zoology.

$\dagger$ Dr. Burt died in January, 1915.

$\ddagger$ Everyone knows, of course, that, with the appointment of Professor Lovejoy, this reproach was removed once for all. 
ing-house in New York, down town just off Broadway, in which a very famous murder had once been committed, I saw him for weeks at another table and looked upon him with reverence and admiration. He had just got home from Europe. It must have been about 1868 or 1869 , and I was in the theological seminary. I looked up to him as fulfilling my very highest ideal - a man who had been abroad and knew philosophy. I think our acquaintance then was limited to a few calls, but he did loan me books and encourage me. I think he was then resident tutor in the family of Jesse Seligman in Gramercy Park, 19th Street, and was spending his time translating Ueberweg with the very utmost care and solicitousness in running down every reference. Henry B. Smith admired him very greatly. Later, when he was called to Michigan, he did me a very great kindness, in getting me appointed his successor at the Seligman's. I found both the children and the parents had the very highest admiration and regard for Morris. Some years later, when I was at Antioch, between 1872 and 1876, I made a visit to Michigan, saw Morris again, and he and Frieze were very kind to me and took me about. I had never realized Morris's musical ability. Our last contact was along in the very early eighties, when we were both lecturing for some months at Johns Hopkins, and boarded at the same place. Here we saw far more of each other than ever before, and had endless talks. He had developed a good ways toward the Hegelian position, which his writings illustrated, and so we did not agree. I always felt that his philosophical opinions were so much a part and an expression of his personality, that one could hardly differ from them without danger of losing a little of the warmth of his friendship, and I always felt that his cordiality toward me, although he did not allow it to lapse consciously, faded. I think we were both in a sense on trial for a chair at Hopkins; and, when the spirit of the university decided for my experimental type, instead of for the history of philosophy, I always felt that our friendly relations were at an end.

"I do not think it was ever my privilege to know a man to illustrate the temper of a true, pure scholar more than Morris did. He was so gentle and inward and reserved, that I always felt a great deal of restraint in his presence, as well as awe for his 
scholarship, which was greatly increased when I saw the extent of his library in Michigan, and his familiarity with it. I do not believe even Morris, with all his friends, ever had among them one who looked up to him as a younger man to an older with greater reverence and admiration. I should never have had my years of enthusiasm for the history of philosophy but for Morris and, though I went in another direction later, there are few men I owe more to."

All these considerations serve to explain, partly at all events, President Angell's frequent comment:

"I could never understand why Gilman did not take more pains to place Philosophy upon a footing commensurate with its importance."

The truth was that, like other men, Gilman suffered from limitations, and had been caught up in the antiphilosophical reaction so characteristic of the second half of the nineteenth century. He did not understand that the principle for the philosophy of the future

"has been found: it lies in that organic conception of the Universe which has its foundation in Plato and Aristotle, and which, continuing from them, will have to complete itself in a profounder examination of fundamental ideas and through an interchange with the science of reality."*

Nor did he realize that the methods of the positive sciences can be applied to but few philosophical questions, and these chiefly of a preliminary order. $\dagger \mathrm{He}$ could not be expected to see that ultimate problems often make cowards of men, leading them to take refuge in the outer courts of the temple of thought. Nor could he foresee that, within a generation, it would be conceded that the positive sciences have little or nothing to say about the Real. He could understand 'advance in

* Logische Untersuchungen, F. A. Trendelenburg, Preface (2d ed.).

† Cf. A. G. Webster, Science, Vol. XXXIX. (new series), pp. 42 f. 
knowledge' by the laboratory route; he could lay finger upon the applications of this research to healing, to commerce, to political administration perhaps, and, by consequence, agree that contemporary thought had won to nothing but anarchy. And, in an age when a Wundt could declare, Wir sind alle Epigonen, he may be forgiven. As we shall have occasion to observe later,* Morris's mental outlook was also a definite factor in the situation. $\mathrm{He}$ could make no concessions to the rampant spirit of empiricism, none to the rising realism in humanistic studies. He, too, was unable to transcend his time.

Notwithstanding the "atmosphere" and the "spirit of the university," however, Morris had some cause to rest satisfied with the impression he produced. I have referred already to the quality of his pupils. Looking to the small number of matriculants at Johns Hopkins, the quantity need not have disappointed him, especially after the time mentioned by Dr. Burt. Excluding public lecture courses, the number of students was as follows: in 1880-1, 14; in 1881-2, 22; in 1882-3, 47 ; in 1883-4, 28 ; and in 1884-5, 44 .

Meanwhile, on 24th December, 1881, Morris returned to Ann Arbor from Baltimore, to assume the duties of his new chair, "a matter for sincere rejoicing," as the student newspaper said. Personal contacts alone can suffice to convey the impression which he made. I am exceptionally fortunate, therefore, to be able to cite former State Senator Andrew Campbell, a Scot cast in the Carlyle mould, - a thinker by grace of Nature,who has been in the habit of frequenting our philosophical class-rooms for more than half a century. His unique experience runs back to 1S61, when he began to visit

* See Chap. viii. 
Tappan's classes. Thereafter, he listened to Haven, and to Cocker, whom he knew intimately, and for whom he formed an attachment. Later, he came to admire Morris, whose lectures and seminar he attended, and with whom he was brought into close contact in the early days of the Philosophical Society. He has been good enough to set down his recollections, the more valuable that they come from one unusually qualified to judge, not merely on a basis of comparison possessed by no one else, but also in virtue of competent knowledge of the subject, and a mastering intellectual interest. Mr. Campbell writes:

"Professor Morris had a profound and penetrative insight into the real problems of philosophy. His teaching was entirely different from that either of Tappan or Cocker. He made no appeal to authority, but aimed to develop the thought contained in the system. He had struggled for-and obtained-the 'higher vision,' which was accompanied by a rare humility on his part, and helped to make him the delightful and lovable man he was. He established the Philosophical Seminary, and began with the Prolegomena of Kant, read in the German text. He brought out with great clearness the superiority of the German language over the English for the expression of nice distinctions in philosophical thought. He used to say that the English philosophy was "empirical psychology." The pure stream of philosophy flowed from the Greeks and the Germans. He was uninfluenced by the "Back to Kant" movement, and held strenuously to the higher idealistic movement. The method and quality of his teaching were far beyond anything heretofore done in the University. It took courage and decision to persevere. He did his work well, and it may be said of him, as of the blessed dead, that, while he rests from his labours, his works do follow him. For the work he began is maintained and carried on with a vigour and scope that would have been a source of great satisfaction to him, could he have lived to see it. In fact, the system introduced by Morris has not been changed, but simply modified and enlarged." 
As Mr. Campbell indicates, the change in the philosophical programme was immediate. At the time of Morris's appointment, philosophical instruction was alike conventional and meagre: one term of General Psychology, and of Ontology, in the rationalistic sense; one term of Formal Logic, and of History of Philosophy. Morris, feeling his way at the outset, offered courses in General History of European Philosophy, EthicsHistorical and Theoretical-and a seminary (Kant's Prolegomena). The following year, second semester of 1882-83, he gave History of the Leading Epochs in European Philosophy, Political Ethics, and a seminary in the Science of Knowledge, as developed in Aristotle and the German post-Kantians. When Dr. Howison joined, Real Logic and History of Philosophy in Great Britain were added. While, on the appointment of Professor Dewey, in July, 1884, the thoroughly articulated plan of work, was drawn, which, as Mr. Campbell acutely points out, has been the basis of all we have done ever since.

The recollections of Dr. Angell and others, supported by many notices or hints in current newspapers, make it plain that, during this second period of service, Morris not only played a much more prominent part in the affairs of the university than before, but had also overcome, in large measure, his former aversion to public appearances. We find him at work as an examiner of schools under the diploma system of entrance; he participates in the social affairs of the community, entertaining Canon Farrar, for instance, on the occasion of the visit of the distinguished English preacher. We saw that, in the nine years after 1874, he spoke thrice only. I find records of no less than thirty public appearances 
after 1882 and, doubtless, the list is incomplete. This implies, of course, that he had laid hold upon the student body and, as we might anticipate, the organs of undergraduate opinion contain several pronouncements to the effect that he was the most popular teacher on the staff. Nor was this the issue of cheap methods; quite the contrary. Rather, his pupils caught from Morris some relish of

"those first affections,

Those Shadowy recollections,

Which, be they what they may,

Are yet the fountain light of all our day,

Are yet a master light of all our seeing;

Uphold us, cherish, and have power to make

Our noisy years seem moments in the being

Of the eternal Silence. . . .

Hence in a season of calm weather

Though inland far we be,

Our Souls have sight of that immortal sea

Which brought us hither."

Young and inexperienced though they were, the occupants of the bare benches in the gaunt, low room, felt the transfiguration on the mount. One of them,* exceptionally well fitted to judge, says:

"His scholarship was unusual for a professor of philosophy in this country a generation ago; and many a secular minded or antagonistic young person, who more or less resented the 'Christian Spiritualism' ... in the professor and his classes (though never in the professor's own central moral spirit), was distinctly reached by his scholarship and scholar's temper, and carried away, for life, new perceptions, new standards, in dealing with truth. . . . When the appeal of his subject began to take hold of him ... there was no raising of the voice . . . but all the

* Professor George Rebec (University of Oregon), Michigan Alumnus, Vol. XIV, p. 189. 
more on this account, the speaker's unwilled-sometimes halfwilling-intensity and persuasive power dominated and suffused the class till its mood became like that of worship in a church."

At the same time, Morris began to take a constant part in the affairs of the Church. Following a long line of his predecessors and colleagues-Gunn, Fasquelle, Frieze, Douglas, Palmer, Denison, Moses Coit Tyler, and the present President of the University-he was elected to the Vestry, in 1882; to the Senior Wardenship, in 1883. He presided at the organ often, read part of the service sometimes, became a member of the executive board of Harris Hall, the students' Guild House, and gave freely of his talents to the courses of lectures delivered there. It was most meet, therefore, that his principal memorial should have been placed in St. Andrew's Church, Ann Arbor, as we shall see.

When Cocker died, in 1883, Morris was still under contract with Johns Hopkins for the first half of each academic year, and it was dubious whether Michigan could command his entire time without an effort. This unpropitious fact opened the way for other possibilities. Even more unfortunate, the factional disturbances that rent the university after 1875, had left their legacy. Some members of the governing board grew accustomed to approach educational questions from a quite irrelevant standpoint. One such-a minister of the Gospel, strange to relate-conceived the recondite idea that personal friendship with himself constituted a main qualification for the vacancy. He proved so insistent that his nominee, a worthy teacher of Greek in a small denominational college, a thoroughly 'safe' person whose achievements in philosophy were nil, received the refusal of the post. In other words, this adventitious combina- 
tion of circumstances nearly resulted in humiliation. Morris might have been lost to Michigan at the eleventh hour, in favor of a man who, despite his fifty-three years, had the naïveté to tell the authorities that he had begun at once "a most earnest preparation for the duties of the Chair!'* Luckily, the 'deal'-it merits this name, I take it-proved to be impracticable in the end, much to the relief of the President. And Frieze who, more than any one else except Tappan, had built himself into the university, wrote to Morris:

"When the opening presented itself for your return to our faculty, I was in a constant tremor for fear there would be some insuperable obstacle in the way. ... There is great need of more men of middle age, of mature experience, of coolness as well as tact amidst our present preponderance of young men, with the liability every now and then to impulsive action."

The bucket brigade, which is always alert "to prevent the flames from spreading when some genius kindles a genuine fire of truth and beauty," was foiled for once.

In November, 1883, Dr. George H. Howison who, later, at the University of California, became one of the two most successful teachers of philosophy in the United States during the last generation, was called as Morris's associate. It may be added at this point that Dr. Howison's early transfer to California was followed by the election of Dr. John Dewey; and that, when he went to the University of Minnesota, in 1888, Dr. Williston S. Hough replaced him. Cocker, Howison, Dr. Dewey, and Hough were thus Morris's colleagues during the seven years and nine months of his all too brief occupancy of the Michigan chair of philosophy.

* Proc. of the Board of Regents of the University of Michigan (1881-6), p. 429 ; cf. p. 371 . 
We have seen that Morris had renounced allegiance to the dynasty of ideas that ruled him in youth, and that, as a result, he was suspect with those who remained content with the traditional, or cataclysmic, view of human experience. The incident which we are to note next, although quite devoid of importance in itself, serves to illustrate another difficulty, troublesome to fundamental thinkers a generation ago. Darwin-to substitute a name for a movement-had applied the idea of Development in a particular field. Now, as Dr. Henry Fairfield Osborn says,

"The discovery of a great truth . . . is always followed by an over-valuation, from which there is certain to be a reaction . . . when there comes a fresh adjustment of scientific values."*

Morris did not live to see the 'reaction' against a partial explanation; his lot was cast when the 'overvaluation' ran to extremes. As in philosophic duty bound, he protested against it. He had therefore to suffer obloquy from the young lions of the 'new scientific' philosophy, no less than from the old Giant Popes of Protestant dogmatism. In his crabbed way, Carlyle took the point well:

"Nature in late centuries was irreverently supposed to be dead, an old eight-day clock made many thousand years ago, and still ticking on, but as dead as brass, which the Maker at most sat looking at, in a distant, singular, and now plainly indeed, incredible manner. But now, I am happy to observe, she is everywhere asserting herself not to be dead brass at all, but alive and miraculous, celestial-infernal, with an emphasis that will again penetrate the thickest head in the planet by-and-by."

Morris would have none either of the irreverence or of the infernal. He knew freedom, not as a capricious

* The Popular Science Monthly, Vol. LXXXIII, p. 535. 
privilege of intellect, but as a tremendous duty to man's whole experience-at once natural and spiritual. In short, he was under bonds to bare the superstitions of naturalistic scepticism no less than those of supranaturalistic convention. Hence our episode.

"The secular minded or antagonistic young person," of whom we heard a moment ago, could not be expected to hide his light under a bushel. Naturally enough, it is from him that the single recorded attack upon Morris-if, indeed, it merit this dignity,-emanates; a disagreeable contrast to the spirit of affection mingled with reverence that pervades all other utterances. The time was February, 1884, when, with the final appointment to the vacant chair of Philosophy still pending, it seemed plain that Morris must be chosen. The ground of criticism reflected the callow Aufklärung fashionable then with some undergraduates, whose thinking lay altogether ahead. Indeed, it was a survival of eighteenth century Weltweisheit which, thanks in large measure to their preoccupation with middle-class politics and commerce, continued to pass for philosophy among the English-speaking peoples, for nigh a century after the Critique of Pure Reason.* The valiant spokesman charged, briefly, that Morris and Howison were "totally out of sympathy with that thought which is admitted to be most characteristic of our own race and time" ; $\dagger$ and, at much greater length, that their political teaching was "fundamentally opposed to the spirit of our own institutions as well as of every other good government.” $\ddagger$ The eagle screams here, striking the

* Cf. My Kant and His Philosophical Revolution, Part I, Chap. ii. $\dagger$ Chronicle, Vol. XV., p. 150. Just this view had much to do with the Johns Hopkins affair.

$\ddagger$ Ibid., p. 151 . 
note that was to dominate the symphony of McKinleyism. Of course, as was inevitable, the writer betrayed his ignorance when he came to cite authorities: "Wm. M. Evarts, Professor Sumner, and Henry Ward Beecher; as well as President Barnard, of Columbia College."* A marvellous quartette in the gallery of great philosophers, one might add! No wonder that a somewhat crushing rejoinder said:

"He has the simplicity to support his plea by authority of H. W. Beecher and President Barnard. Did he ever hear of idola theatri? But we are tired of such nonsense. If any one desires ... to to fit himself to write further charges with credit to himself, let him take the courses of Philosophy offered in the University, wherein he will hear what of truth, not only Kant and Hegel, but Mill and Spencer have to offer." $\dagger$

Morris's critic thereupon falls back upon another display of ludicrous naïveté, objecting that "the professors ... . come to very different conclusions from those of G. H. Lewes, in his history of philosophy." $\ddagger$ Lewes as the standard authority on history of philosophy, in the year of grace 1884, is indeed food for immortal laughter! Dr. Angell told me that the incident caused some amusement, at the expense of the writer; and an alumnus who belongs to this period, writes, "I doubt if students in general took much interest in the matter." Nevertheless, it intimates something as a symptom. For, as my correspondent adds, the critic "was the most aggressive of a group of men who took pride in advanced ideas on philosophy, politics and religion, and were ardent followers of Herbert Spencer."

* Chronïcle, Vol. XV., p. 151.

$\dagger$ Ibid., p. 190.

$\ddagger$ Ibid., p. 210 . 
In short, it serves to prove that Morris had a real work to do. The belle lettrist amateurism of John Gibson Lockhart, all very well in the salad days of The Quarterly Review, had migrated overseas, to masquerade as dogma. "What!" Lockhart said, speaking of the whole movement central in Groethe, "would you introduce that $\mathrm{d}-\mathrm{d}$ nonsense into this country?" It remained for Morris to teach that the intellectual parvenu and the sinner stand in identical case; both must be born again. And many such as Morris are needed, even at this good hour, to assist the new birth.

On 8th March, 1884, in the historic philosophical class-room,* before an audience “ of about 150," $\dagger$ Morris read a paper on "The University Idea and the Relation of Philosophy to the University." When he concluded,

"Prof. Payne was called to the chair, and a motion was made and carried to organize a philosophical society for the discussion, investigation and study of philosophical subjects, and for the purpose of increasing the interest in this important study at the University. A committee consisting of Prof. Morris as chairman, and Messrs. Jerome, $\ddagger$ Buckley, $\S$ Haff || and Miss Case $\uparrow$ was appointed to draw up a constitution and report it at an early date. Remarks were made by Dr. Angell upon the importance and influence of such societies. There is much enthusiasm in the matter among the students of philosophy." "**

As long as he lived, Morris was the moving spirit in the Society, which accomplished much to stimulate

* 'Old' 21, University Hall, now, alas, 205 North Wing!

† Chronicle, Vol. XV., p. 207.

$\ddagger$ Afterwards an authority on the causes of the Decline of the Roman Empire; author of Roman Memories, etc.

§ Afterwards Professor of Philosophy in Doshisha College, Japan.

\| Now an eminent lawyer in Kansas City; hon. A.M., 1909.

I Afterwards Professor of Philosophy in Wellesley College.

** Chronicle, Vol. XV., p. 207. 
philosophical study at the university. It was no inconsiderable service. For, reorganized since as an 'honour' society, the association continues to sustain a vigorous activity, notwithstanding the enormous change in academic conditions.

Leaving Quebec on 13th June, 1885, Morris made his last visit to Europe, in company with his pupil and friend, Dr. Charles M. Gayley, now of the University of California. A most interesting "Diary" is available. Moses Coit Tyler, then at Cornell, an intimate of both, sent the 'vagrant' couple this amusing communication, of date 27 th June:-

“To the Chief of Police,

Hollymount, Co. Mayo, Ireland.

Sir: I hereby notify you of the escape from this country of two desperados, and of the probability of their early appearance within your jurisdiction. They have been recently incarcerated at Ann Arbor, Michigan; and were last heard from at Quebec, where, on the point of sailing, they seem to have got very drunk, and to have amused themselves by breathing out profanity and violence against their betters. It would be impossible for them to find any one worse than themselves. They have numerous aliases, and no name can identify them. One has the lean wild look of a metaphysician; the other, the hang-dog expression of a poet who is conscious of having written such bad verses as to entitle himself to be damned like his poetry. Both are dangerous characters; and constantly explode, though not with dynamite. Look out for them."

Fog and icebergs-“like castles of the New Jerusalem" - delayed the Sardinian, and the travellers did not find themselves in Londonderry till one a. $\mathrm{m}$. on the 23d. After exploration of the adjacent country, including "a reputed site of Irish kings of the time of 
Solomon," they betook themselves East to the Giant's Causeway, thence to the county of Captain Boycott, where their host had been under police protection from the Land-Leaguers, and so to Dublin. At Trinity College, Morris "sought in vain Mahaffy, Abbott and Dowden," but had the pleasure of seeing Professor Tyrrell, and of chancing upon Professor Corson, of Cornell. On July 9th he arrived in Glasgow- "a great contrast to Ireland. Ireland seems dead, the people slow, lifeless, and disappointed; Scotland-thrift, energy, well-to-do, wealth; much the same contrast as between Mississippi and New England, I should suppose." Naturally, the "beautiful situation" of the University buildings impressed him. The usual round of 'Rob Roy's country' followed, and brought him to Crieff, where he enjoyed the hospitality of Principal John Caird. They seem to have had a most illuminating discussion of philosophy and philosophers. Morris records Caird's account of Thomas Hill Green: "Most remarkable. Impersonation of self-sacrifice, always the one to respond to the call of distress and want."* $\mathrm{Ar}$ rived at Edinburgh, Morris saw Calderwood, Flint and A. C. Fraser, and heard Professor Andrew Seth lecture on "Scottish and German philosophy admirably." He learned that "one or both of the Haldanes were likely to go into Parrliament. This most encouraging for the future of politics, on account of their brightness and their strength in political philosophy." $\dagger$ Very characteristically, Flint told him that "they had not yet got much beyond the old style of teaching at Edin-

*Cf. Works of Thomas Hill Green, Vol. III.; the "Memoir," by R. L. Nettleship.

$\dagger$ The career of Lord Haldane fully justifies this prediction. 
burgh in philosophy. No history of philosophy. The notion of history of philosophy as a growth only beginning at most, to germinate."

From Edinburgh Morris went to Bradford, for the express purpose of seeing Professor A. M. Fairbairn, with whom he spent a day; thence to Manchester, where he was greatly vexed to find that Professor Robert Adamson was in Ireland, on holiday. Luckily, Professor Edward Caird was nearby, in North Wales, and Morris had a couple of days with him at Bangor, where he also met Mr. (now Sir) Henry Jones-"a bright fellow." Morris notes a "distinct direction of Green and Caird, and their men, to practical and social life."* From Wales he journeyed, through the Shakespeare country, to Oxford, where he was the guest of Mr. F. H. Bradley, at Merton College. He saw something of Green's successor, Professor William Wallace, and was surprised to learn from him that "teachers of philosophy in Britain see very little of each other," also to hear that Professor Croom Robertson had enough ado to keep Mind going. He was evidently struck by the Oxford plan of philosophical study, and comments:

"The statutes require here philosophy to be founded on Plato and Aristotle. So, every candidate for a degree [he should have said, an honour degree] must know much Greek, and be able to read the Greek philosophers and historians in Greek. Modern philosophy, the statutes say, may be read-not must. To make much of it, it has to be brought in by way of, or as an appendage to, Greek philosophy. Not precisely so: there is a paper required in Logic and Modern Philosophy, in which much Modern Philosophy may be brought in and, in one course, portions of

* Cf. My articles, Some Lights on the British Idealistic Movement in the Nineteenth Century (The American Journal of Theology, July, 1901), and Edward Caird (The Harvard Theological Review, April, 1909). 
Kant's Kritik may be read. But, certainly, one must know the Greek authors and, especially, much of Aristotle's Ethics. So F. H. Bradley says."

He discovers that "books on Moral Philosophy sell best. Bradley's Ethical Studies was all sold in four years. His Logic, and Wallace's Logic of Hegel, go more slowly." Having seen the sights, and called upon Professor Samuel Alexander (now of the University of Manchester), Professor J. Cook Wilson (d. 1915), and Mr. W. L. Courtney (now editor of The Fortnightly Review), Morris left for London, where he immediately repaired to Covent Garden, and heard Patti, as Marguerite, in Gounod's Faust. He was disappointed to miss Professor George Croom Robertson, who was out of town, and Mr. Phelps, the American Minister.

Leaving Queenboro' for Flushing, he arrived at Cologne on July 23d, whence he went to Bonn, where he spent an evening with Professor J. Bona Meyer and was soon on familiar ground, in Halle, despite the lapse of seventeen years. Here he heard the venerable J. E. Erdmann lecture on Fichte, Schelling and Hegel; met his future colleague, Dr. Hough, and saw his old friend, Professor Lphues. He also made the acquaintance of Professor Vaihinger, who "talked at lightning speed," and told him that "Estheties is rarely taken up at the German universities comparatively. The Philosophen also give, as a rule, no attention to Religions-philosophie. Ethics is lectured on by almost everybody, in contrast to the state of things a few years ago." In short, Morris found himself midmost the full tide of the NeoKantian and Ritschlian reaction,- the "attempt to combine theoretical scepticism with religious mysticism," as Dr. Karl Uphues put it. Acccompanied by 
Dr. Hough, Morris then repaired to Leipzig, where he met Professors Wundt and Heinze. He found that fifty-nine Americans, five Canadians, and nine Englishmostly Scots!-were pursuing studies in the University. He heard Wundt lecture on Logic and, having tried to persuade him to make a visit to the United States, received 'no' for an answer. Wundt pled in extenuation lack of time, and a limited knowledge of the English language.

The next move was to Berlin, where "I was addressed in the National Gallery by Miss Leach, of Vassar College, whom I met in Baltimore." Morris saw the aged Zeller, but had the bad luck to miss Paulsen, who was beginning to attract attention as a lecturer just then. $\mathrm{He}$ had an interesting visit with Professor Otto Pfleiderer, at Charlottenburg, who "complained of the clique-iness from which he thought perhaps Dr. Adolf Lasson had suffered. It might be the reason of his not being a full professor." Thereafter, he saw Lasson, who "agreed that an end to the present prevailing Kantian agnosticism, and the recognition of Hegel, would have to come."* After a brief stay at Dresden, Morris returned to Halle whence, after seeing something more of Erdmann and Uphues, he proceeded to Heidelberg, to call for Professor Kuno Fischer, whom he found "very friendly." Fischer maintained that, "while there was no school of Hegelians, bound to defend the system as Hegel left it, the world was coming, and must come, to recognize the truth in him." "He was interested," Morris continues, "in my account of the revival of philosophy at Oxford, and in learning how

* Dr. Lasson, still drawing crowds at Berlin till the Great War, lived to see the fulfilment of his prediction. 
many hearers Wallace had had" [as many as one hundred].

From Heidelberg he travelled rapidly, via Strassburg and Basel, to Lausanne, where he had a joyful reunion with his old friends, the Joëls, among whom he spent ten days in delightful recreation. On August 24th he was in Paris; next day, in London, en route for Liverpool, where he was again disappointed to find Professors A. C. Bradley and John MacCunn absent on vacation. He was greatly-and justly-impressed by the general excellence of the collection of pictures in the Walker Gallery. On the 27th, he sailed, aboard the Circassian, and arrived at Quebec on September 6th.

This tour was a source of keen pleasure and strong stimulus to Morris. He gave an account to the Philosophical Society* of the thinkers whom he had met and, as a tangible result, procured the reproduction of Sir George Reid's portrait of Edward Caird, which still hangs in the philosophical class-room. He frequently reverted to those inspiring meetings, when in reminiscent mood. His hosts, too, remembered their gentle and scholarly guest with delight; the brothers Caird, Wallace, Fairbairn, Flint and Pfleiderer have all, at one time or another, spoken to me about the visit; the Cairds and Flint, in particular, referred to it often.

Immediately after Morris took ship for Europe, his colleague, Professor Charles Kendall Adams, had been elected President of Cornell University, and had gone into harness on 1st August, 1885. The following are excerpts from one of his earliest official letters:

"IтhaCa, N. Y., Aug. 15, 1885.

"My dear Morris: I have not heard a word from you since you took ship and left the country for your own good, though I

* Cf. Michigan Argonaut, Vol. V., pp. 134, 140. 
have been for some weeks hoping that I should hear from you. Before this reaches you, perhaps your good wife or some other good person will have informed you that my destinies have been transferred from Michigan to New York. . . .

"President White's term of office according to the record extends to the First of September, but he was especially anxious to be relieved and therefore, at his request, my own commission went into effect on the First of August. I arrived here on the morning of that day, and since that time I have been sailing about on what may fairly be called 'a voyage of discovery.' . . .

"Among the matters now receiving my earnest thought is one about which I desire particularly to consult you. This is, you will not be surprised to learn, concerning the matter of a professor of philosophy and Christian ethics. I have read and re-read all the correspondence on the subject turned over to me by President White. We are ready to make the appointment, and should make it at once, with the hope that the new incumbent would enter upon his duties at the beginning of the coming year, if we could only satisfy ourselves in regard to the man. . . . I want such advice as you alone among my acquaintances can give. . . .

"Now, what I propose is this: that on your arrival in New York, when you are ready to start for home, you take the Lehigh Valley Railroad and stop over one day in Ithaca. ... Of course, I am reluctant to keep you for a single hour from your wife and children after you arrive here. . . . But I really need your advice, and I hope you will take a little trouble to sacrifice so much to our old friendship.

"Very heartily and affectionately yours, "C. K. Adams."

There is no record of this proposed visit; but Morris did submit names to President Adams who, after investigation, wrote to him, on 12 th November, 1885, as follows:-

"My interviews gave me no reason for changing the view I had previously held. I have seen Mr. Sage since my return and, consequently, am ready to take up the matter at close quarters. 
I am satisfied that you are the man for the place and that, if you will authorize us to go on, we shall elect you on Friday of next week. . . . I believe that, with the beginning of a new year, and the courses of study reorganized, you will find a good opportunity for such work as you desire to do. Hoping that you will decide to come and that your coming will be divinely directed for good, I am, my dear fellow, very affectionately yours,

$$
\text { "C. K. Adams." }
$$

Moses Coit Tyler, a 'powerful persuader' with Morris, exerted his blandishments:-

"IthacA, N. Y., 13 Nov., 1885.

"My dear Morris: I have just had a long talk with Adams about you, and I feel that you are the Providential man for this great place which opens to you. I do hope and pray that you and your dear wife will see that it is best for you to come. I would not press upon you undue solicitations: but let me say this. If you are willing ever to make one more change in life, is not this the best time for it; and could it be made under more favorable circumstances, or with a richer promise of usefulness? This is certainly to be a great seat and centre of intellectual influence.

"Affectionately,

"M. C. Tyler."

Two days later, Tyler returned to the charge, with the important news that Mr. Sage had decided to increase the inducements, and concluded: "If you say-'yes'say it at once: if "no'-don't say it at all!"

The charm of the community-life in Ann Arbor-so well known to us all-which, as is often said, turns 'outlanders' into better Michigan men than Michigan men themselves, had laid its spell upon Morris. And, ere long, his resolve to decline the Cornell offer became public. "The decision caused great rejoicing."* Well,

* Cf. Michigan Argonaut, Vol. III., p. 65. 
indeed, it was for Michigan. But, in view of the circumstances which resulted in his death, one can scarce refrain from surmising what might have been, had Morris gone to Ithaca and, reaching the three-score years and ten, administered the Sage Foundation. It is perfectly obvious that the fortunes of several individuals would have been altered profoundly; and that, possibly, the history of academic philosophy in the United States would have taken a somewhat different course.

In the four years that still remained to him, Morris was engaged busily in consolidation of the work of his Department, growing steadily the while in general influence and, no less, in the respect and affection of the immediate community. He met the common lot in the way of joy and sorrow. Writing, at Christmas, 1886, to his Lausanne friends, he says:

"We all spent about ten weeks in the East, mainly in Vermont, during the summer, enjoying it extremely. One of the pleasantest things in our vacation was a carriage trip of nearly 200 miles across the Green Mountains, and back to our startingpoint. It was lovely. We have since thought it very providential that we spent a large part of the summer with my father, for only a few weeks after our return to Ann Arbor he died, rather suddenly. He was almost 89 years old, and during the summer he was in very good health."

In 1886, he projected and published the University of Michigan Philosophical Papers, contributing the first number, University Education, and editing later issues, by Professors Calvin Thomas, W. H. Payne, B. C. Burt and Henry Sewell. In 1887, he published his last work, IIegel's Philosophy of the State and of History, in his own series of German Philosophical 
Classics. In the last Christmas letter that we possess, to his Lausanne friends, the Joëls (1888), he says:

"Our University is very prosperous. The attendance here is larger than at any other American University. We have over 1800 students. Of course, I am still enjoying my work. I am very busy getting ready to write a book on the History of Logical Doctrine, to be published in London and New York. It will take me at least a couple of years to get it completed."

The reference is to his contract, which lies before me, with Messrs. Swan, Sonnenschein and Co., of London, to contribute a book on Logic to The Library of Philosophy, then, as now, under the editorship of my former class-mate, Professor J. H. Muirhead, of the University of Birmingham. Morris had made many notes, which are preserved, but had written nothing ere his death. It is pathetic to note that, of the works promised in the first announcement of this invaluable Series, no less than six were interrupted by death-those of Morris, W. Wallace, Ritchie, Adamson, E. Caird, and Hough. Morris appeared occasionally as a lecturer at other places, notably at the Concord Summer School of Philosophy, where we find him associated with many important names; and at Trinity College, Toronto, where he delighted to be the guest of the late Professor William Clark, a winsome personality, a link with the days when Mansel was just beginning to exert sway at Oxford. Last year, I chanced to recover an interesting echo from one of these Canadian visits. Morris wished to walk and, Clark being busy, Mr. Herbert Symonds (now Vicar of Christ Church Cathedral, Montreal) was told off to accompany him. Dr. Symonds informs me that, in the course of their tramp, Morris exclaimed: "I wish I had two lives, one to devote to Philosophy, 
the other to Theology!" This remark, made in 1888, is worth noting in connection with the letter, written in 1882, to the Secretary of the Class of 1867 in Union Theological Seminary, where Morris says:

"My connection with the Class was severed just at the middle of the course, and the study of theology has never been renewed by me."*

Without doubt, his excursions into the realm of Philosophy of Religion had led him to regret that he possessed no greater familiarity with technical theology.

His last public appearance was peculiarly appropriate. It took place on 15th November, 1888, when he read a paper on "The Greek Philosophy of Music" before the University Musical Society, now, thanks to his labours, and to those of Frieze especially, one of the most potent influences for the elevation of life in our midst.

The end overtook him, as well as his nearest and dearest, unexpectedly; and it were wiser not to draw the veil which shrouds the pitiful and tragic events of that month. Suffice it to say that, always fond of the open, Morris had a cottage at North Lake, some nineteen miles from Ann Arbor, whither he resorted often for rest and recreation. The 'call of the wild' being upon him, he went there with his boy, on February 22d, 1889. As is usual at that time of year in Michigan, the weather was in rough, surly mood, and, returning home the next day, both caught a severe chill. The son developed fever, and his condition became alarming. The father whose case did not arouse anxiety, improved after the first weakness; but a relapse occurred, and death ensued, on March 23d. Caught unawares, and bereaved most

* Cf. above, pp. 91,92 . 
sadly, the entire community was shocked terribly and moved to its depths. Extraordinary manifestations of grief and respect marked the occasion of the funeralto Forest Hill Cemetery, Ann Arbor-on 27th March, 1889.

In our circles, at all events, it is abundantly plain that, 'he, being dead, yet speaketh.' For his person, self-hammered into complete unity with his teaching, conveyed a lesson which persuades us to affirm,

"He knows that outward seemings are but lies, Or, at the most, but earthly shadows, whence The soul that looks for truth may guess

The presence of some wondrous heavenliness."

Note.-It may serve to prevent misunderstanding if, at this point, I append a statement of the positions held by Morris in the University of Michigan, with the respective dates:

(1) Professor of Modern Languages and Literature; September, 1870, till June, 1879;

(2) Professor of Modern Languages and Literature (ad interim), June, 1879, till January, 1880;

(3) Professor of Ethics, History of Philosophy and Logic (serving one semester in each academic year), June, 1881, till January, 1885;

(4) Professor of Ethics, History of Philosophy and Logic (Head of the Department of Philosophy), January, 1885, till June, 1887;

(5) Professor of Philosophy (Head of the Department of Philosophy), June, 1887, till March, 1889. 


\section{CHAPTER VII}

\section{Intellectual History. Origins and Transition}

When we come to attempt an estimate of Morris as a thinker, several difficulties must be acknowledged, and borne in mind throughout. First, materials for an intimate review of his entire mental history are lacking. Till the year 1874, when the Ueberweg translation and the articles on Trendelenburg were published, we find ourselves compelled to fall back upon such general considerations as we may derive from the tendencies of New England culture taken as a special phenomenon. No doubt these are definite enough. But, second, documentary evidence fails us to mark the steps whereby he passed from childhood faith to a more or less sceptical mood. Personal recollections, too, are scanty. For, sensitive and shy, he never wore his heart on his sleeve. Nevertheless, it is certain that, during his first years at Michigan, he was ill at ease, to some he appeared even distraught. Third, for eight years after 1870, his main strength was absorbed by active work as a teacher of modern languages. Likely enough, this may have been advantageous - he was under no temptation, much less compulsion, to declare himself, and so avoided the troubles of premature pronouncement. He had time to mature his conclusions and, fighting his way through while his teachers receded into the past, he schooled himself after his own fashion. Indeed, the characteristics, noted already by Dr. Tucker in college days, were destined to mark him always. His later thoughts, 
like his early opinions, attest his personal outlook rather than the influence of masters. In any case, it is not till 1880 that he begins to betray a distinct swing towards the standpoint with which he will ever be associated in the history of American philosophy. His major contributions belong to the last eight years of his life. Finally, it must be insisted that, at the time of his death, he was a young man, comparatively speaking, and that, consequently, he never reached the point when he might gather himself together, as it were, in a magnum opus, offering conclusive summary of his mental achievement. When the end came, he was still in process of growth.

On the other hand, happily for us, these obstacles to complete understanding, as we may call them, are relieved to a certain extent. For, first, nothing could well be more coercive than the norms that moulded Morris, the boy and youth. Moreover, they conferred an immense initial advantage upon him. It was impossible for him to hark back to a time when the real importance of the problems of philosophy had been obscured, or even adjourned sine die, by the pressure or glamour of evanescent affairs. Constitutive principles, regulating life pervasively, had been his familiars from the outset. Hence, secondly, the curve of his mental career was, not simply a personal reaction to provincial conditions, but rather representative of a great movement in his generation. Nay, it may be said to typify the spiritual history of many men-some destined to place and influence, others unknown to fame - during the third quarter of the nineteenth century, particularly in the English-speaking world. The ' Divine Decrees' that governed the youth originated the problems 
and set the perspective in manhood. Like others, Morris did not escape the intervening process scatheless. The subject of a profound transformation, his first certainty never returned full circle. Yet he knew that he had chosen the right road, and he saw the goal in plain view. The pragmatic seriousness, present from boyhood, had been a free gift from his folk, and he was destined to preserve it throughout. But this past rendered him permanently wistful, because he never could regain naïve assurance. No less, however, it wrought like a leaven, for, through years of poignant struggle, he did achieve a gospel-this being his paramount need. In common with other idealists of his day and generation, in America and Britain, practical interests, especially those of religion and morals, were never far from him. And so, in the nature of the case, mystical hope, somewhat to the exclusion of systematic completeness, replaced confident affirmation.

"Yea, though I am not now such strength as in

Old days bewail'd but earth and fear'd for heaven,

Such as I am, I am: knowing myself.

So I have gathered up all left behind

Like to the wholeness of the onrolling year;

That there is no regret: but onwardness."

\section{Origins}

As we have seen at length already, Morris grew to adolescence in a very definite social, moral and spiritual environment. No group-consciousness was ever more certain of itself. It became so completely part and parcel of his selfhood that it swayed him long after he had surmounted its standards of ethical judgment, and rejected its theological convictions. For, we cannot 
disguise the fact that his philosophical interests converged upon the highest human ideals, more or less to the exclusion of the order of Nature. The positivist attitude, with all its implications, remained alien, even distasteful-one had almost said disreputable - to the end. This appears continuously, from his first published essay, on Hodgson's Time and Space, till the latest expression of his views, in the pamphlet entitled University Education. His qualities and, no less, the defects of his qualities, root here. It is essential, therefore, to consider the formative phase in its broader aspects and, if possible, to do it every justice-the more that to-day, it is often misunderstood, when not actively misrepresented, so far has it become a mere memory among us.

We have tried to appraise the Morris home and the influences irradiated by it. We ought to note, farther, that when the boy went to school, identical forces continued to play upon him. Fortunately, the Historical Sketch* of Kimball Union Academy, written by Principal Cyrus S. Richards, $\dagger$ enables us to form a tolerably clear

* Cf. The General Catalogue and a Brief History of Kimball Union Academy, pp. 7 f. (Claremont, N. H., 1880).

$\dagger$ Richards was an excellent scholar and, moreover, a 'good deal of a man,' as the expressive phrase runs. He seems to have pervaded the school. I am fortunate to be able to present the following reminiscences of the man and the institution, from the hand of my colleague, Mr. Raymond C. Davis, Librarian Emeritus of the University of Michigan:

"In the autumn of 1852, the New Hampshire Literary and Theological Institution, where a brother and myself were students, was removed from New Hampshire to Vermont. We did not choose to accompany it, but, instead, went to the Kimball Union Academy at Meriden. As I recall the school, it should class with the two more famous academies, Phillips Andover and Phillips Exeter-except, perhaps, in equipment and financial backing. The instruction was very thorough, and the discipline strict. 
estimate of the temper of the institution. Richards had received his secondary education in this school, over which he presided with remarkable success for thirty-six years (1835-71).

"The historic record of this institution dates back only about seventy years. Our country, just recovering from a long and depressing war, with a population then of only about seven millions, was entering upon a career of great prosperity. Emigration was in full tide toward the Great West. Meanwhile a deep taint of French infidelity, introduced by the late war, was becoming wide-spread and alarming. Good men were everywhere aroused to lift up in opposition a standard of righteousness and truth; to raise up and send forth, amid the teeming populations, an evangelical and educated ministry. The demand greatly exceeded the supply.

"About the year 1811 a son of Deacon Joseph Foord, of Piermont, N. H., had gone to the north of England or Scotland to prosecute Theological studies, attracted by a popular institution, affording gratuitous instruction to candidates for the Christian ministry, in indigent circumstances. ... He urged the establishment of a similar one at home. . . . The exigencies

“Mr. Cyrus Richards, the principal, was an unassuming man, but somewhat of a tyrant, nevertheless. He was known among the students as the Great kîpos; and, as he was small of stature, this must have had reference to mental qualities. It was pleasant, after so many years, to hear this title again from the lips of Professor Morris.

"As illustrating the unpretentiousness of the man (Richards), I remember some words of his regarding titular distinctions.

"When we called on him, on our arrival in Meriden, he questioned us in regard to the New Hampshire school. In our replies we spoke of our teachers as professors-as they were addressed, and referred to, in New Hampshire. At the second utterance of the word, he interrupted with some heat:-

"'You say professors - that title should not be used in speaking to, or of, a teacher in an academy. It is the title of an occupant of an endowed chair in a college. You must not apply the title to me or any one connected with this school. I am Mr. Richards.' [Richards did not receive the degree of LL.D. from Dartmouth till 1865.]

"He would be a disgusted man if he lived in these days!" 
of the times-the great lack of candidates for the ministry gave favor to the new idea." After several abortive attempts, a council of the leading churches in New England was convened at Windsor, Vt., in October, 1812. President Dwight, of Yale College, was the leading spirit, and deprecated "the establishment of schools with a partial and limited course of studies, even for the purpose of multiplying ministers." As a result, the Seminary was abandoned in favor of a less ambitious academy, "whose object should be, as set forth in the charter,- 'To assist in the education of poor and pious young men for the gospel ministry.' . . . None could become beneficiaries under this arrangement without the declared intention of pursuing the full course of college and theological studies. It was christened by this body with the name of Union Academy-it being the offspring of the united churches of New England. . . .

"Hon. Daniel Kimball, of Meriden, N. H., arose in the council and said that God had blessed him with a liberal fortune, but with no natural heir to inherit it. He recognized the providence of God in this movement, and was ready to pledge the institution six thousand dollars for immediate use, and the bulk of his property at his decease. This offer ... determined its full name after the decease of Mr. Kimball, in 1817. . . .

"Under such auspices, then, did this institution enter upon its most useful career. Any adequate history of its future, of nearly three quarters of a century, would require several volumes, rather than the few pages allotted to this introduction. The full record will be disclosed only when the books are opened in the revelation of the Great Day.... .

"The patronage of the school ... at once became very large; gathered not only from all the New England States, but from much a wider circle of almost all the States and also from the Canadas. . . . And such patronage, too, as certainly cannot be found out of New England . . . gathered largely from the middle, industrial classes, from Christian homes of the Puritan stock, bred to habits of industry and economy, and not afraid of hard work. This was a natural result of the primal object of the institution-to assist and encourage Christian young men, in indigent circumstances and of promising talents, for the ministry. . . . The value of a band of earnest, Christian young men 
in a large school, as a conservative and efficient power, cannot easily be estimated. This will account, in part at least, for the high moral and religious tone of the school, and for the powerful and most precious revivals of religion, during almost its entire history. . . .

"Little space is left me to speak of the results and fruits which have been the outgrowth of an institution thus Providentially founded and cared for. . . . The record is safely recorded above. How much plainer and fuller shall we understand it all, when the 'Book of Remembrance' shall be opened! . . . The day of unveiling draweth on, when all the deeds of men will be truly judged."

The Biographical Sketch of the Hon. Daniel Kimball,* which follows Dr. Richards' history, is to similar effect.

"At the age of twenty eight he experienced, as he believed, the new birth, and was ever after warmly devoted to the service and interests of Christ's kingdom.

"When the deliberations which resulted in the founding of the Academy began they naturally attracted the attention of Mr. Kimball. His sanctified intelligence could see the importance of such an institution. . . . Then the Lord had prospered him, while he had no children, and he must have asked himself to what best use he could put his wealth. Thus he came early into the councils of these good men who were seeking to lay these foundations for Christ and His Church."

Nurtured and directed thus in home and school, Morris, as a pupil at Kimball Union, and as an undergraduate at Dartmouth, placed on record, in his Private Journal, opinions which, in our day, are nigh inconceivable as coming from such a quarter. Several extracts may be quoted by way of farther illustration. Moreover, they will compel us to seek the fundamental principles presupposed in this all-embracing institutionalism but, of course, not yet consciously envisaged by the lad.

* By Rev. Henry A. Hazen, A.M. Cf. Ibid., p. 14. 
The following passages, typical of the tone of the Journal as a whole, embody the reflections and paramount interests of a Sophomore during the latter part of his academic year, strange as this may seem to us.*

"Yesterday, Professor Boardman, of Middlebury College, preached at Norwich. I had never heard him before, and I am free to confess that he surpassed in some respects my expectations. His sermons were of the richest character.... He spoke words of living truth. He preached in the morning upon the sufferings of Christ, showing that they were deeper than His mere physical suffering on the Cross; that Christ felt, in the hours preceding His crucifixion, the burden of our sins, and that the Christian faith implied a full belief in this fact."

"Last Thursday evening, I took charge of a meeting in the Vestry to which all were invited. The meeting is under the direction of the Young Men's Christian Association. I took for my subject the sixth verse of the third chapter of Proverbs: 'Trust in the Lord with all thine heart; and lean not unto thine own understanding.' I first defined true and false trust in God, and then mentioned some of the motives for trusting in the Lord."

"I have not written in my journal so often during the last year as might perhaps in some respects have been useful. But it is not strange that one who is not nerved, in respect to every duty, with a strong and overruling determination to perform that duty, should frequently allow himself to leave many opportunities unoccupied. . . . I feel as if I really had something now which is worthy to be recorded. I feel sensible that God has graciously manifested Himself to me. For never before yesterday have I known in an equal degree the blessedness which arises from a feeling of entire consecration and submission. Not that I do not still 'groan, being burdened;' for I am still in possession of a rebellious heart; I am still unable to do what I would-or rather, I still lack the disposition to do what I should. But yesterday, after hearing a sermon in the forenoon by Mr. Boardman from Psalms'Lord, show me the measure of my days'-relative to the death

* Cf. American Thought from Puritanism to Pragmatism, Woodbridge Riley, pp. 55, 175. 
of Dr. Richards of this place, and another in the afternoon, from Luke, xviii., 1, upon the duty of constant prayer, I returned to my home and, after my usual custom, retired to my room for private prayer and, by the grace of God, was enabled to ask for spiritual blessings with such force and devotion, that for most of the time since I have felt constrained to say, 'Bless the Lord, O my soul!"

"This afternoon President Lord-in compliance with a request from the students-delivered in the College Chapel a eulogy upon Prof. Young, who died last fall. . . . The first half of the discourse was taken up with remarks on the wrong tendency and results of the cultivation of the intellect without a corresponding religious culture, and asserted the destructiveness or inutility of learning and fantastic wisdom-thus acquired-for any good purpose. He then showed off Prof. Young's life as a good illustration of the proper combination of sanctity and learning."

Death had made inroads upon Morris's circle during this year. Considerable portions of the Journal are devoted to comments upon the subject, to which he returns later, in his Senior year. His reactions are indicative of his contemporary outlook.

"Arthur Morris Kellogg, if he were today alive, would be eleven years old this day. But his body is not now alive, although that which in reality constituted him a person is, without doubt, still full of life, and is now, let us hope, just beginning a life of eternal blessedness. . . . His death was a most severe blow to his widowed mother, as well as an affliction and shocking providence to us all. For he was a boy of unusual promiseconscientious beyond what is usual among boys. He feared to disobey God, or his parent. True, as in other boys, the inclination to do evil often prevailed, and the rod of correction had to be applied, but his corrections and instructions were by no means to no purpose, and showed themselves in an increasing adherence to the right as the years increased in number. His religious experience was extended. Being, as he was, the child of many prayers, and having had the benefit of the pious instruc- 
tion of his mother almost daily, as well as the weekly teachings and admonitions of his Sabbath School Teacher, and having been much influenced by the words of Mr. Boardman, especially during the revival of January-February, 1858, his mind had been disturbed by many reflections upon his lost condition by nature, and upon the way of salvation through Jesus Christ. And many times he had expressed the hope that he was a Christian, and although, at first, in a way which seemed to belong to one not thoroughly understanding what he said, yet finally leading his Mother, who was his confidant in religious matters, to indulge the hope that he was an 'heir to the heavenly inheritance,' and that, although the immaturity of his age prevented him having the faith of Christ in the same manner in which one of riper age and broader comprehension would hold it, still he had a child's faith and a child's love, and that in such a way as to secure his admission to the fold of Christ, in heaven."

This extraordinary pronouncement, about a child of ten years of age, brings home, perhaps better than anything else in the Journal, the force and the naïveté of the convictions upon which Morris was brought up. To the same effect are his remarks subsequent to the deaths of three of his comrades in the Senior Class.

"I think that the preceding providences of God to our Class and the College have not been sufficiently considered by Christians, much less by others. Nothing is plainer than that God is calling upon us to 'be also ready'; and that, most assuredly, we 'who have tasted and seen that the Lord is good' ought with the greatest earnestness to make use of God's afflictions and monitory dealings to enforce the great lesson of faith in Christ and justification through His name."

In his last term as a College Senior, Morris set down those reflections upon prayer:

"At present I have ample time for reading, meditation and prayer. I say prayer, for I am convinced that earnest, importunate, habitual and long-continued prayer is the duty of every Christian. It is a duty which cannot be shirked with impunity. 
For, if holiness of life and the conversion of the impenitent are (the one) obligatory and (the other) important, prayer, which is one of the direct methods of attaining these objects, may not rightly be neglected. If time can not be readily obtained in any other way, some inferior duties should be set aside, that we may have an opportunity for sincere and prevailing prayer.

"The present religious state of the College is, I think, hopeful. If every Christian were to set resolutely to laboring and praying for the revival of God's work, how long could it be delayed? If every one were determined not to let God go without a blessing, and were willing to do or suffer anything to secure so blessed an end, can any one suppose that God would be unfaithful to His sacred promises? But, how is this state to be secured in God's people? Only by the working of His Holy Spirit which, again, we may not reasonably expect unless there is prayer and preparation therefor. God grant His Heavenly Grace that I, and others of his professed followers in College, may not be so taken up with literature and earthly pleasure as to forget the higher and all-important good-the presence of the Divine Spirit."

It is by no means easy to disentangle the essential presuppositions pertinent to such views, especially when the material before us happens to be the random, pietistic phrases of an immature undergraduate. Nevertheless, the attempt cannot be avoided, because it is evident that Morris, the thinker, was influenced throughout life by this, his starting-point, far more profoundly than by any other single consideration. To liberate himself from it or, at all events, to rethink it, remained his prime object as it was his paramount need. He began and ended a "Christian spiritualist." Indeed, being constrained, he could not do otherwise. Nay, this is the chief interest of his mental career. For, he passed from .earnest belief into "intrepid thinking on the things of eternity." What Jowett said of Wallace could be affirmed of Morris with no less truth. 
"On his pupils, this secret power of an other-world serenity laid an irresistible spell, and bore in upon them the conviction that beyond scholarship and logic there was the fuller truth of life, and the all-embracing duty of doing their best to fulfil the amplest requirements of their place."*

Fortunately, too, much as they have been misinterpreted by a later generation, the prime factors of the early, formative period happen to be plain enough. We are confronted, if not with a unique, at least with an exceptional combination between common sense or irreflective cognitions and a reasoned, systematic knowledge. The latter, a correction or critical extension of the former as a rule, has, in this case, returned to the level of 'natural knowledge' in common life, and become so absorbed in it as to be regulative of the ideas and activities of the average man, even of the little child. Ordinary faculties are, if not sharpened, then guided by a methodical scheme that has filtered to them from a complete or, if you please, 'scientific,' 'colligated' plan. In short, a real order of existence, the product of concentrated reflection, has been elicited from the apparent order of sensuous things, thus giving ampler import to the plain affairs of the work-a-day world. No doubt, the youthful Morris passes from the one to the other, unaware of the leap for the most part, because he accepts the transcendental order as innocently as he perceives objects that appeal to the senses. Thus, the question arises of the principles distinctive of this system, principles which had come to be a possession of the folk no less natural and heritable than normal powers of sensuous observation. Theological although these were, they

* Lectures and Essays on Natural Theology and Ethics, William Wallace, p. xi (quoted by Edward Caird in his "Biographical Introduction" on Wallace). 
led forthwith to philosophical problems; that is, speaking generally, to the real order of existence as it can be ascertained by disengaging the universal and necessary from the shows of time and sense. Nor was this order a curious theoretical plaything, an excuse for the exercise of intellectual ingenuity. Grasp upon it was inculcated with direct practical intent. Apprehended of it, man would achieve new endurance, would confront his world with new assurance, would put his life out to interest for new purposes, thoroughly worth while.

Its specific development in the North Atlantic States notwithstanding, the New England conscience was no local or provincial product. On the contrary,

"In its wider relations and its deepest sources this movement is not to be fully comprehended unless it is put in its place among the religious movements of the whole Protestant world. . . • The Reformation united the great nations of the Teutonic family which it took out of the fold of Rome by a community of interests, not only political and religious, but also theological. ... Remoteness and rarity of communication do not destroy it. Ties of blood and intimate political relations serve only to facilitate it. The channels of communication, like subterranean streams, it may sometimes be impossible to trace. The whole phenomenon depends upon and illustrates the fundamental unity of Protestantism amid all its superficial diversity. . . . The fundamental connection of New England with all this international ferment and development is seen in the remarkable fact that, in spite of its apparent and real isolation, the great periods of theological history are repeated here with almost identical dates. . . . These facts show how fully New England theology is a world-phenomenon. . . . It was singularly homogeneous, since it derived its motive force from a single source. The materials with which the New England writers wrought, and the later impulses which they received from various quarters, were English, Puritan, Calvinistic exclusively."**

* A Genetic History of the New England Theology, Frank Hugh Foster, pp. $4,5,7,8$. Cf. the whole chapter. 
In brief, we are dealing with one of the several manifestations of the Theology of the Reformed churches. Morris derived his cast of thought from this unique system and, despite radically different spiritual experiences, never forsook the 'climate of opinion' to which he had become habituated as child, boy and young man. Let us try to see why.

The Reformed Theology, as distinguished from the Lutheran, was originated by $Z$ wingli, and received mature expression from Calvin. It attained influence in France, in portions of Germany (notably the Palatinate), in Bohemia, and in England; but it never contrived to dominate these regions. Its clean-run children and most strenuous exponents have been the four very small and very intense national groups - the Swiss, the Dutch, the Scots, and the New England Puritans. It is no accident that these peoples owe their influence in the world-so utterly out of proportion to their numbers and material resources-to their thorough discipline by this system.

A succinct elucidation of its principles, with special reference to their philosophical implications, may best be made, perhaps, by recalling that the Reformed Theology embodied two main, complementary elements. On the one hand, there is the anthropological aspect, as theologians term it, known to philosophers as the subjective; on the other, the theological aspect, strictly so called, known to philosophers as the objective.

According to the former, religion is held to be a natural or essential factor in the constitution of Man. In other words, it is universal, never contingent. This necessarily excludes the Roman doctrine that, consequent upon the Fall, Man lost this endowment which, there- 
after, must be considered a donum supernaturale. That is to say, religion formed no part of the 'essence' of Adam, but was an 'accident'-something bestowed ('superadded' was the technical term) by Divine power. In like manner, the Reformed Theology repudiated the Lutheran view, according to which Man had been so corrupted by the Fall that he could by no means attain true knowledge of God. Even more emphatically, it traversed the Socinian teaching, that Man is devoid of religion naturally, and incapable of knowing God by his own reason which, at best, can assure him nothing higher than morality. On the contrary, the Reformed Theology held a religio naturalis innata. As Calvin affirms, writing of the Dei sensus: "Quendam inesse humanae menti et quidem naturali instinctu divinationis sensum extra controversiam ponimus. Hic divinitatis sensus nunquam delire potest." It is obvious that this teaching wholly excludes such philosophical standpoints as Nominalism, Empiricism, or Positivism; in this respect, its influence upon Morris can scarcely be exaggerated. It leads straight to some form of Divine immanence. As is well known, Zwingli went far in this direction. But it may surprise some to learn that Calvin, in his teaching with regard to "Acquired Natural Religion," did not lag far behind. "Non solum mentibus indidit Deus religionis semen, sed se patefecit in toto mundi opificio: ut aperire oculos nequeant quin aspicere eum cogantur." Evidently, reason thus becomes Platonized intelligence-a faculty conversant about transcendental ideas. The First Book of Calvin's Institutes- "On the Cognition of God the Creator"makes this abundantly plain. Nor is this all.

"Chapters VI. to IX. [of the Westminster Confession] present the usual doctrines of the Evangelical Reformed (Augus- 
tinian) anthropology, with the new feature of the Covenants. The doctrine of the covenants belongs to a different scheme of theology from that of the divine decrees. It is biblical and historical rather than scholastic and predestinarian. It views man from the start as a free responsible agent, not as a machine for the execution of absolute divine decrees." $*$

This new doctrine,--bred in the bone with Morris,which held that "the Bible is the history of redemption, in the form of a covenant between God and man after the Fall," made room for a rational account of the development of religion, thus prefiguring the Hegelian system. A series of stages, each higher than its predecessor, had occurred in history, until, at length, an 'absolute' stage was reached, thanks to the revelation through Jesus Christ.

It would seem, therefore, that interpreted philosophically on its anthropological side, the Reformed Theology must have afforded Morris, not merely excellent preparation, but also materials which he had only to free from mechanical orthodoxy in order to lay bare fundamental principles of a thorough y rational character. Certainly, this stream of tendency lay hidden from him for many years. Moreover, I think that, in his ignorance of technical theology, which he came to deplore, he never saw the connection clearly. At the same time, it is unquestionable that the temper and outlook induced by his early norms served but to direct his steps afterwards, and to confirm him finally in the convictions that marked his later philosophy.

Similar affirmations may be made with regard to the theological or objective aspect of the Reformed teaching.

* The Creeds of Christendom, Philip Schaff, Vol. I., p. 773. Cf. J. Cocceius, Summa Doctrina de Fadere et Testamentis Dei (1648); F. Burmann, Synopsis Theologiæe et Economice Faderum Dei (1671). 
For example, in contrast to Ritschlianism,--the reduction of Lutheranism to an argumentum ad hominem, with, one must admit, the authority of Luther, who railed at Frau Vernunft, calling her "the old trouble-maker,"the Reformed Theology is absolutist and gnostic, in the sense of theo-gnostic. It points to God as the ultimate ground of reality, known in His essential nature and attributes, manifesting Himself in all things, with crowning consummation in the revelation of Jesus Christ. Of course, this view was long identified with and largely obscured by the Augustinian doctrine of predestination and election and, especially in New England, the subsequent dispute about the freedom of human will served to divert attention from the original principles. Something of this sort cost Morris his prolonged détour. At the same time, when the mechanical or realistic lapses of many Calvinists are swept aside, what we actually find is insistence upon a synthetic Divine teleology, with immediate extrusion of dualism in all its fecund forms. A concrete Weltanschauung, as the fundamental contention runs, is natural to Man. For, according to the essential theory, Man is known to be, not merely the subject of a free self-consciousness manifesting God's eternal purpose, but he is also aware that, by possession of a 'chief end,' he is the vehicle of this manifestation. Or, putting it otherwise, human nature attains universal self-consciousness when its innate religious capacity has become so developed that it can body forth the objective principle-God. Thus, the Fall takes rank as a means to a more direct or adequate revelation of the 'eternal consciousness'-a 'moment' in the evolution which leads to perfect 'mediation.' Hence, the operation of the Holy Spirit becomes 
the consummation of the world-process, and the recognition of the indwelling of this same Spirit, in Grace, the irrefragable basis of religious certainty. Once more, then, it was no far cry from the unconscious phrasings of the Puritan lad to the "Christian spiritualism" of the mature professor. The perspective of the theological system does not differ widely from that of the idealistic philosophy-except in so far as theology is not philosophy. Accordingly, Morris was but returning home from a lengthy and devious journey when he could recognize, with Green:

"We must hold then that there is a consciousness for which the relations of fact, that form the object of our gradually attained knowledge, already and eternally exist; and that the growing knowledge of the individual is a progress towards this consciousness."**

One might infer readily, then, that a Theology so profound would have sufficed to furnish Morris with satisfactory, if not final, positions. But we must remember that, thanks to Protestant scholasticism in the seventeenth century, and to the controversy with the Deists in the eighteenth, which forced the evangelical participants into an untenable position on behalf of apologetics, the original principles were forgotten or overlaid. $\dagger$ It became necessary to stress prophecy

* Prolegomena to Ethics, p. 75 (1st edition).

† Several distinguished theologians have protested against the apologetic corruptions of the Reformed Theology. Chief among them are: F. C. Baur, Katholicismus u. Protestantismus (1834); H. L. J. Heppe, Die Dogmatik d. Protestantismus im 16. Jahrhundert, 3 vols. (1857), Ursprung $u$. Geschichte d. Bezeichungen 'reformirte' $u$. 'lutherische' Kirche (1859); Die Dogmatik d. evangelische-reformirten Kirche (1860); J. H. A. Ebrard, Christliche Dogmatik, 2 vols. (2d ed., 1862-3); Wissenschaftlichte Rechtfertigung d. Christenthums (2d ed., 1878-80), in Germany; A. Schweizer, Die protestantischen Centraldogmen, innerhalb d. ref. 
and miracles as external proofs of the Christian revelation, while revelation itself came to be conceived as a lawless inbreak from an unknowable realm. Men committed themselves to the error, literally tremendous in its consequences since, particularly after the middle of the nineteenth century, that evidence applicable to the objects of sense, and methods of proof available in the natural sciences, can be transferred to the objects of religion. In common with so many others in his day, Morris had to pay his full share of the penalty for this strange blunder.

Moreover, the influence of the Scottish School of philosophy, which began to assert itself in New England about 1820, proved unfavourable to vital discussion of ultimate problems.* Reid and his followers were interested in descriptive psychology, for the rehabilitation of common-sense, so severely mauled by Hume,

Kirche, 2 vols. (1854-6), Die christliche Glaubenslehre nach prot. Grundsatzen dargestellt, 2 vols. (2d ed., 1877); M. Schneckenburger, Vorgleichende Darstellung d. lutherische u. reformirte Lehrbegriffs, 2 vols. (1855), Die Lehrbegriffe d. kleineren prot. Kirchenparteien (1863), in Switzerland; J. H. Scholten, De Leer d. Hervormde Kerk in hare Grundbeginselen (1855; German trans., from the 4th ed., 1865), in Holland. None of these works influenced Morris's philosophical teachers; nor can I find that they were inwardly marked by his theological professors. H. B. Smith was stimulated most by Neander and Twesten, both disciples of Schleiermacher, and by that notable representative of the 'new orthodoxy' in Germany, Hengstenberg; he was also influenced, like Morris himself, by the theism of Trendelenburg and Ulrici, the philosophers, of Berlin and Halle. But he owed most to Tholuck, the Halle theologian, perhaps the most representative member of the Conciliation or Mediating School of Theology, with whom he was on terms of close personal friendship. On Tholuck's pietism see J. Stalker in The Expositor (eighth series), vol. IV., pp. 159 f. (1912); cf., Germany: Its Universities, Theology, and Religion, Philip Schaff, chap. xxvi., (Philadelphia, 1857).

* Cf. American Thought from Puritanism to Pragmatism, Riley, pp. $120 \mathrm{f}$. 
as they understood him. Besides, being devoid of speculative insight, they did not, as indeed McCosh himself suggests,* realize "the profound peculiarities" of the Reformed Theology. Judged by the standards of contemporary German thought, of which the philosophical professors, unlike the theologians of New England, would seem to have been ignorant, their metaphysic was uncritical and unscientific-there was nothing of the zu Ende denken about it. As Chalmers, writing so early as 1801 , had the wit to see, it was "made up of detailed hints and incomplete outlines," and "almost uniformly avoids every subject which involves difficult discussion." $\dagger$ So, too, in New England,-the University of Vermont under Marsh a striking exception, $\ddagger$ - the prevalent method was to divide the philosophical field into specific disciplines, descriptive psychology and intuitional ethics forming the centres of main activity. Accordingly, a body of correct knowledge was taken over uncritically from ordinary experience, by appeal, overt or tacit, to custom and tradition. It was thus easy for the clerical occupants of philosophical chairs to keep peace between philosophy and theology, by the simple expedient of confining themselves to 'safe' subjects. On the other hand, the metaphysical presuppositions-'full of dynamite,' as they always are-were relegated to the theologians who, in their turn, were able to expound the 'true' system without interference from a shattering philosophical criticism. Hence, Burton and Taylor and Park and H. B. Smith, to name no others, merit lasting remembrance, they

* The Scottish Philosophy, from Hutcheson to Hamilton, p. 299.

† Ibid., p. 281.

$\ddagger$ Cf. American Thought from Puritanism to Pragmatism, Woodbridge Riley, pp. 161, 170. 
were doing significant work, but-where were the free speculative thinkers, the pure scientists in the things of the mind? In a word, the average experience of 'respectable, Christian' men in New England afforded a norm which few, if any, in the colleges at all events, dreamed of questioning. Thus, no thorough assault upon fundamental problems could occur and, as a matter of fact, none did occur.

But this combination of circumstances. seems to have affected the philosophical teaching chiefly, and must by no means be taken in derogation of the general situation in the New England colleges of the time. For it is apparent that the Arts course had its own distinct merits. On the whole, students were well served, sometimes admirably, as, for example, in Greek at Dartmouth. They attained a certain skill on what we may call the rhetorical side. That is to say, they had opportunities to acquire literary information, and to make considerable progress in the art of expression. A most creditable paper by Morris, The Nature of Poetry, lies before me. It was prepared for and read before the Psi Upsilon Chapter; and internal evidence shows that this kind of 'exercise' constituted the main, if not the exclusive, concern at meetings of the Fraternity. Evidently, eating, sleeping, house-parties, and 'peanut' politics had not attained their present and vast importance! Another paper, belonging to the same period,- the Senior year,-Philosophy before Bacon, proves that Morris had adequate information, as scholarship then went, about Græco-Roman thought, although his teachers had aroused no suspicion in him of its bearing upon his own actual thinking. The account of Plato, for instance, is entirely external, and marked by gross 
misconceptions, especially about the Theory of Ideas. Further, undergraduates were not only left free to read what they pleased, but encouraged to acquaint themselves with the works of the great writers, past and present, irrespective of the views urged. In brief, their powers of acquisition and expression were disciplined, although original thinking was not emphasized, and so their conventional ideas of life remained unaltered. They came to college with a purview, and left, knowing not what manner of men they were. No doubt, American political prepossessions, and the false emphasis laid upon 'freedom' by the great controversy of the hour, also conspired to this end. In any event, deeper problems were postponed, - inevitably, perhaps. Symptomatically, then, Morris appears to have been affected much more by his teachers of Greek and mathematics than by the philosophical professors. He acquired much, but he thought little, and this quite conventionally.

The materials available to throw light upon his attitude during the period between the close of the college course and the enlistment in the United States Volunteers are scanty, unfortunately. Yet, one long passage from the Journal; two short papers, Truth and Joseph Garibaldi; and two lectures, on Astronomy and Geology, composed and delivered at Royalton, confirm wholly the conclusions just stated above. The entry in the Journal illustrates, with great force, how completely Professor Noyes had fallen victim to the apologetic distortion of the Reformed Theology, and how unsuspectingly his best pupil accepted the professorial version for gospel. And, as we shall see, the Royalton addresses, written more than two years later, and after a wider study of the physical sciences than was usual then, are to the same effect. 
Morris, after detailing the subjects on which he has been engaged, proceeds to remark, in the Journal:

"One of the most profitable and interesting branches has been that of Natural Theology. Paley's work is the textbook which the class used. But, in examination, that was not made the basis of operations so much as some 'topics' given out by Prof. Noyes-all connected with the subject of the Existence of God as proved from geology in particular and nature in general. These topics had some reference to Paley's Treatise, but consisted mostly of arguments for the Divine Existence drawn from the sources above mentioned, and fully stated and drawn out in various works, such as Hitchcock's "Religion of Geology," Brougham's "Essay on Natural Theology," the Writings of John Foster, etc.

Through the kindness of Prof. Noyes, I obtained a copy of the "Religion of Geology" a few days before the examination took place, and found it to be a most profitable and interesting work. If people would only study, and know how things are, having a right disposition and a useful aim, I am sure there would not need to be so much ignorance and doubt in regard to the truth of great doctrines, and such as are of vital importance. 'Ignorance is bliss,' you say, perhaps; but hard-earned knowledge is much more than that; and, without doubt, one of the chief delights of glorified spirits is derived from the fact of their vast increase of knowledge. And yet we do not say that the possession of knowledge, in itself considered, is the realisation of the blessedness of heaven. Far from it. For, in that case, the most godless man, provided he be one of great knowledge, would necessarily be supposed to have in the present life a 'foretaste' of eternal bliss. But there is a satisfaction and a pleasure in the possession of knowledge, although it may be lost to some extent, in this life, through the effects of sin, and a diseased heart and blinded conscience. ... Knowledge will thus become what it will become here, so far as polluted human nature will allow,-the medium of increasing felicity - a felicity more boundless even than the realms of knowledge."

He then goes on to reflect upon the necessity laid upon the Christian to study the evidences for his "dearest hopes," and continues: 
"Now, of course, I am unable to say from my own knowledge how much that may be learned outside of revelation with respect to God's Existence and His Eternal Laws has already been learned; but I do know, from reading such works as that of Hitchcock already referred to, that much that is important has been discovered; and I know, too, that the possession of these discovered and attested facts has a tendency to enlighten one's Christian faith, and to make it stronger and clearer. These facts, too, are of a general and comprehensive kind, to a great extent, having relation to the everywhere existing laws of nature, to the testimony of the rocks, and the ways of God upon earth. They are well worth knowing, and I am glad that the subject of Natural Theology has been made a regular branch of study for students at Hanover. . . Prof. Noyes has entered into the work with considerable earnestness, and has shown a sincere desire to affect the consciences of the students, and bring their hearts to a state of peace with God."

In strange contrast with these "eccentric gesticulations in a wind of our own raising," as Stirling calls them* is the Platonizing tendency of the following, taken from the brief paper on Truth, written, be it remarked, only six weeks later!

"All men are agreed as to what Truth, as an abstract quality, is; but, as to what is truth, in a given case, nothing but the irresistible evidence of facts, or an express revelation from heaven, has ever been found, in the present state of things, to cause men to agree. ... We will use the word truth in this connection, not in its minor relations to and dependence upon changeable facts, but as existing abstractly, and not necessarily connected with that which exists physically. . . . The two most important attributes of Truth are its unchangeableness and illimitedness. .... It has its habitation at the throne of the Eternal God. It constitutes one of God's brightest and most glorious ornaments and is coeval with Him, existing from eternity to eternity. . . . We must consider it as the necessary basis for all earthly or human stability, and much more as the foundation of our immortal hopes."

* The Secret of Hegel, Vol. I., p. xliii. 
Evidently, Morris harbours not the faintest suspicion of the lurking contradiction between the two pronouncements. It has never occurred to him that the methods proper to treatment of determinate physical phenomena avail us nothing to reach ultimate reality. In other words, he is guiltless of philosophical system, and without clear appreciation of the aims of science. Hence, no doubt, the confusion and pain he was destined to endure afterwards.

This innocent postponement of fundamental questions, and no less innocent attitude towards the implications of science, receive farther illustration from the Royalton lectures. It is to be remembered, however, that science still occupied a very secondary position in the college curriculum, was, in fact, the merest incident; and that, although Morris learned a good deal about the paraphernalia of observational astronomy, thanks to his two years' residence in the Shattuck Observatory, he could not well escape the general atmosphere of indifference and, even, ignorance. The following, almost the last entry in his college Journal, affords food for apposite reflection:

"Mr. John Lord, Clergyman, has been delivering a course of Lectures on the Representatives of Modern Civilization. Those on Galileo, Lord Bacon, and Pascal were particularly fine. In the first he expended his powers of sarcasm on the 'Bread and Butter' Sciences, mentioning especially Chemistry and Geology, much to the disgust of certain devotees of those departments of knowledge. One of them, my classmate Hoyt, was stimulated thereby to write his Commencement Oration on a subject thus suggested - 'The Relation of Science to Religion'taking a position opposite to that of the lecturer. For my part, I am glad to see men that make a hobby of their scientific studies occasionally rebuked." 
Mr. John Lord, Clergyman, as the natural expert authority upon the history of scientific discovery; science itself as implying nothing more than "bread and butter"; and devction to science as an insidious fad needing hebdomadal rebuke-these be thoroughly characteristic misconceptions. Science, as the handmaid of something else, was all very well; but science for its own sake had not yet swung into the visible heavens. Hence, the tone of the Rovalton addresses is at once genuine and informing. The lecture on Astronomy gives a careful and correct account of the aims of astronomical observation, and a clear description of the instruments then in use, but with symptomatic lapses into the edifying. The great age of the science is asserted.

"The fact that several of the stellar constellations are mentioned by Greek writers who lived one thousand years before Christ, and some by Job whom chronology places five hundred years earlier than these, testifies to its early existence."

Job in $1500 \mathrm{~B}$. C. is, of course, a theological phantasy, but the scriptures must be upheld! This passage typifies the general outlook.

"The sun is not only the chief source of influence in the solar kingdom, but is asserted on high authority to be itself revolving about a centre that has been designated, and in a circle of vast diameter. Thus we have the earth attended by a moon that revolves about it - the same being true of several other planets,we have the planets, with their attendants, revolving about the sun, and the sun about some other centre; leading to the magnificent generalisation of a certain philosopher, that each centre, with its system, rotates about a still more powerful focus, till the whole universe is included in one vast system of systems, moving, one vast stupendous whole, in obedient regularity about the throne of the Omnipotent Himself."

Curious notions about the history of religion crop out. 
"There is strong evidence that the sun is the first body that received divine honors from men after the worship of the true God was forsaken."

But, "verily, the sun is, to human apprehension, godlike, and depraved humanity may be looked upon with greater charity (though not pardoned) for rendering him supreme homage." Poor Zoroaster! One of the main "uses" of astronomy is

"in developing the sentiment of morality, and in strengthening religious impressions. ... The visible universe constitutes a standing argument to demonstrate the glory and power of the Creator. A correct appreciation of its vastness and undisturbed order, together with its marks of exquisite design, strengthens in the mind the belief in the Deity. As this sentiment gains ground, the sense of obligation increases. The sense of personal consequence is diminished. The feeling of subjection to the control of an Infinite Power is increased."

As one might anticipate, the lecture on Geology emphasizes even more the 'utility' of Natural Theology, although, at the same time, it offers a fair, if somewhat inaccurate, account of the results of geological investigation. Two points are worthy of special note. Morris affirms;

"It is proved that the earth is not 6,000 years of age merely, but has existed for myriads of centuries. Man may not have seen light till the period indicated by the Mosaic record, but the earth must have existed, and been the abode of organized existences, long before the noble thought of God gave itself expression in the creation of Man."

But he hastens to add,

"If any one is disposed to inquire how this can harmonise with the account of the creation furnished in Genesis, I have only to say that the facts of Geology do not conflict with a fair and intelligent interpretation of the sacred canon. Nor do they 
diminish in the least the respect and reverence due to the word of God, or the authority of its teachings. Particular explanation of this point cannot now with propriety and convenience be given."

\section{Again, he admits the evidence for Evolution.*}

"It is shown in Geology that the earth, previous to the introduction of man upon this sphere, was inhabited by several races of beings succeeding each other in the scale of their comparative development and nearness to man in structure. ... Those faculties which are brought to a comparatively complete stage of development in man, are, therefore, to be considered as having existed embryonically in birds, fishes, reptiles and creeping things before man, as such, ever saw the light. Geology teaches that change is the law of terrestrial, as well as of all created things. The earth is not now as it has been, or as it will be. . . . Before the final catastrophe of a destroyed world shall take place, as predicted in the unalterable word of God, vast alterations may take place in the physical condition of the globe."

Nevertheless, as before, he hastens to add:

"Nothing material can interest the mind save as significant of what some designing intellect has formed. . . The infinite variety of signs of benevolence and will, now impressed indelibly upon the face of nature, would not exist to excite our interest, and occupy our thoughts ... unless we recognised God's hand in the world around us. It befits not an immortal being to become so oblivious of the most important realities, through devotion to present gratification, or through heedlessness, as to ignore the Omnipotent finger that has inscribed upon every created object the lesson of God's government, and our own dependence."

And he concludes:

"View God in everything - in the sea and the land, in the hills and the valleys, in the volcano and the earthquake-an omnipotent and beneficent Deity!"

* Cf. American Thought from Puritanism to Pragmatism, Woodbridge Riley, pp. 194 f., 206 f. 
Once more, the apposition has escaped him and, sooner or later, the unstable equilibrium is bound to be upset.

Finally, the essay on Garibaldi serves to show that, like his countrymen generally, Morris was preoccupied by an individualistic political theory, which he regarded as a species of final revelation. So, at the time, the politico-social problem had come to him solved. On the whole, he is not much given to high-flying. But, on this occasion, he aviates with the Bird of Freedom!

"Upon the day when the American People are jubilantly celebrating the thirtieth anniversary of Independence declared and Civil Liberty ensured, in the city of Nice, lately ceded to France, fortune favored a sea-faring man by bestowing on him a son. ... The spirit of freedom which the occupation of his early life undoubtedly inspired in him, when he was accustomed to look with impassioned delight upon the blue expanse of waters, and watch the gentle rippling of the lightly rolling surface, or gaze with appropriate awe upon the unrestrained fury of the tempestuous waves, this spirit of freedom, I say, doubtless influenced strongly, although, perhaps, on his part, unconsciously the feelings and principles of his later life. . . . Is not this man, then, worthy of his present honorable position as commander of the united forces of what were formerly separate states, now joined under the King of Sardinia, for the maintenance of their Constitutional Rights? . . . In Lower Italy he stands forth to-day as the acknowledged leader of all aspirants for Civil and Religious Liberty. . . . May God grant him success in his present attempt, to deliver from bondage a people of superior and classic lineage, and to rescue from further defilement by tyranny a land of illustrious historical associations!"

It has been well said, that "every man who rises above the common level has received two educations: the first from his teachers; the second, more personal and important, from himself." This 'second education' 
preponderated with Morris. We have tried to analyze the 'first.' From now on, we are concerned more with the 'second.' For, despite the influence of H. B. Smith and Trendelenburg, Morris never called any man master. Through a full decade, materials fail us, and the best we can obtain must come by way of inference. Nor is inference, however unsatisfactory, altogether hopeless. For, it is certain that the 'first education'-by the New England conscience and by teachers-remained the terminus a quo throughout the period of transition.

\section{Transition}

There is no evidence that, during the years of service in the army and as tutor at Dartmouth, the views with which Morris left college underwent change, On the contrary, such documentary scraps as we possess indicate that without any qualms of conscience he held to his original intention, of preparation for the ministry of the Congregational church. It is doubtless true that experiences in camp acquainted him with a side of human nature in strong contrast to that familiar in the sheltered life of rural New Fngland. This has been considered sufficiently above. But the testimony of pupils at Dartmouth proves that he returned to the College unaffected substantially, so far as others could observe. Nor were they wrong; the resolution to proceed to Union Theological Seminary is of itself decisive on this point. It is more than probable, therefore, that the first signs of coming stress manifested themselves in the seminary period. The hints dropped by fellow-students, as we have seen already, confirm this inference.

No direct clue exists to the reasons for Morris's spiritual unrest as it showed itself in the second year of 
his seminary course particularly. Yet, his previous mental history supports the conclusion, that his extensive and most varied reading, over a term of more than six years, had asserted its effect at length. The youth had been led to admit at least a possible attitude towards the meaning of life in violent contrast to the doctrines of his nurture. We should remember that these were the days of that great intellectual awakening, revolutionary in character, now known as the method of science, critical and natural. And many indications, pointing as if by concerted plan in the same direction, must have led an acute youth to observe that some cherished convictions, central to his home-made creed, were under serious fire. Moreover, he had not come by the newer views through the discipline of the laboratory, with its sober restriction to objects than can be weighed, measured or numbered. He had stumbled upon them in works, often semi-popular and of general interest, where much metaphysic, indifferent or bad, was mixed crudely with valuable matter of no metaphysical import. In short, he found himself, almost unarmed, amid the onrush of the battalions of halftruths and half-absurdities that marked the fifteen years after The Origin of Species; when the eighteenth century apologetic, attacked on its own ground with modern weapons, went down to utter disaster.

He knew something of Comte as interpreted by Lewes and Mill. He had encountered a foe, almost within the gates, in Bushnell. He was familiar with Hamilton and Mansel, the advance agents of Spencer. He had read Essays and Reviews, Draper, Renan, and John Mill. "Preconceived law," as Calvinists understood it, and a "perfecting principle," in the Aristotelian sense, if 
brought down to traffic with physical phenomena, as the Design men had brought them down, could hardly be expected to survive the evidence, arranged now on such a scale that the old position was outflanked completely. It is obvious, of course, that Morris was in no state to foresee the issue; but it is nevertheless unquestionable that he sensed grave trouble and experienced disheartening qualms. In these circumstances, Smith, from all we know of him, was the very man who might have saved the day. The fact is, that he did not; nay, that he abandoned the effort, advising Morris to forsake theology and present plans of preparation for the ministry, and to hie him to Germany, where Ulrici and Trendelenburg might furnish weapons to counter this strange enemy. Accordingly, we are driven to ask, Why did Smith fail? And we must reply; First, and mainly, because he himself did not belong to the epoch just opening, and so proved unable to meet the vital problem; second, because the inevitable atmosphere of a theological seminary then did little to support his influence, much to limit it.. This may be said, too, without casting the slightest reflection upon the man or the institution. The large, irresistible movement of the second half of the nineteenth century was beginning to sweep Morris away. Nothing but first-hand commerce with it could suffice to satisfy a thinker. A decade of struggle lay ahead; and, even then, sure footing was not to be attained.

The situation in which Morris found himself, little as it may have affected the average seminarian of fifty years ago, was not by any means unusual. Its homethrusting difficulty has stricken able men time and again down the centuries, although at no period more severely, 
perhaps, than during the first onset of modern science. And, in the nature of the case, its tremendous issues have loomed largest with religious believers, particularly those who, like Morris, had enjoyed a calm season of serene faith. So much so, indeed, that the most apposite statements of it come from two eminent theologians of the last generation. Despite their sharp antagonism otherwise, they agree here. Thus, Albrecht Ritschl says:

"On the one hand, man as a spiritual being claims to be of greater worth than the whole natural system; and, on the other, finds that he is cribbed, cabined and subjected by the latter."*

While his opponent, Otto Pfleiderer, declares, with no less insight:

"The reconciliation of our present knowledge of nature and history with the religious faith handed down in the Church, and imparted to us in our education, will remain in the future the perpetual problem of theology."' $\dagger$

Why, then, did the instruction at Union Seminary, especially that of Henry Boynton Smith, the most influential and competent member of the staff, fail to deliver Morris from the dilemma?

Smith was the first of the great succession of New England theologians to come into intimate contact with modern German thought and, in a measure, to master its implications, freeing himself from the Scottish philosophy. $\ddagger$ But despite interest and no little facility in pure philosophy, the theological standpoint always dominated him. The frequency with which he charact-

* Drei akademische Reden, p. 10.

$\dagger$ The Development of Theology in Germany since Kant, and its Progress in Great Britain since 1825, p. 205 (1st ed.).

$\ddagger$ Cf. A Genetic History of New England Theology, F. H. Foster, pp. 439 f.; " Review of Upham's Mental Philosophy," H. B. Smith, Literary and Theological Review, pp. 621 f. (1837). 
erizes the thoroughgoing philosophical systems as "pantheistic" is significant. Accordingly, visiting Germany for the first time in 1838 , he was led to regard the 'mediating theology' of Schleiermacher, then in possession at Halle and Berlin, where he studied, as the main phenomenon. In addition, the Hegelian school was in process of dissolution, and a reaction against the speculative systems had begun; they were already under fire from Ulrici and Trendelenburg. Smith lived with the former, and knew the latter well. Moreover, theological circles were agog over The Life of Jesus, Critically Examined, by D. F. Strauss, the enfant terrible of the moment, who, thanks to the panic he created,* it must be borne in mind, exerted enormous influence in leading his opponents-among whom were Smith's friends and teachers-into bypaths. Affectionate friendship with Tholuck, a delightful but mystic soul, $\dagger$ and intercourse with Neander, served to confirm Smith farther in the 'conciliation' eclecticism of the Schleiermacher group. Thus his chief concern naturally became, and always remained, the relation between faith and philosophy, their union the end in view, without, however, a reasoned philosophical system upon which he could draw for principles such as might have enabled him to think the problem through to the bitter end. Consequently, he spent his mental strength in a continuous doublerefraction process, itself the outcome of a false abstraction between two indissoluble sides of human experience.

Introducing into the doctrines brought from Germany an important objective element obtained from the Calvinism of the New England succession,-from which he

* Cf. The Quest of the Historical Jesus, a Critical Study of its Progress from Reimarus to Wrede, Albert Schweitzer, Chap. ix.

$\dagger$ Cf. above, pp. 99, 110, 195. 
never wavered,- -he recognized the urgent need for a first principle or 'fundamental norm' in theology. Thanks to this, he was able to correct to some extent Schleiermacher's weak treatment of the justice of God in the work of redemption, and to illuminate his inadequate conception of personality. Notwithstanding, having enunciated the necessity for a principle, he did not apply it, and failed to free himself from Protestant subjectivity, in which, after the manner of Schleiermacher, he took refuge when hard pressed. He says, characteristically, "Rome does not know how to reconcile Christianity with popular right, nor reason with revelation."* The judgment of Pfleiderer upon the German disciples of Schleiermacher applies most aptly to Smith.

"In the case of the majority, the requirements of their personal devout feeling, and still more regard to the real or supposed wants of the churches, prevailed to such an extent as to lead them to put on one side the critical element in the theology of Schleiermacher, and to use his formulæ rather for the purpose of hiding or modifying the difficulties of the supranaturalistic theology than to encourage them to advance beyond the old standpoint along the new paths of the master." $\dagger$

Asserting that faith “is perfectly rational," $\ddagger$ Smith nevertheless flouts all attempts to refer it to philosophical first principles, because, paradoxically, he himself still remains in large degree under the spell of Deistic rationalism, a trait of the positive Vermittlungstheologie as a whole. Accordingly, when confronted with the bad,

* Faith and Philosophy, Discourses and Essays, p. 82.

$\dagger$ The Development of Theology in Germany since Kant, p. 122 (1st ed.).

$\ddagger$ Faith and Philosophy, p. 14.

$\S$ This appears plainly throughout his Apologetics, $A$ Course of Lectures (edited by William S. Karr, 1882), and in the third Appendix to the 
or naïve, metaphysics of the 'natural philosophers,' he fell back upon positions scarcely less uncritical than those adopted by Draper and the early Darwinian exhorters. His printed remains prove him to have been a singularly accomplished man, of unusual mental receptivity,except to the factual methods of natural science and, in lesser measure, to the logical rigorism of the postKantians. Despite the opinion of Dr. F. H. Hedge,"I believe you are better acquainted with Hegel than any one else in this country,"* - the brief excursus, contributed by Smith to Hedge's 'specimens,' and his article in Appleton's Cyclopodia, suffice to show that he saw Hegel from the outside. $\dagger$ The reason is obvious, and it cannot but have weighed much in his dealings with Morris. Like others, Smith was thoroughly scared by the developments in the so-called Hegelian left, Strauss particularly. $\ddagger$ While he could have appreciated, and countered from the abundant armoury of technical theology, the violent attack made by Strauss upon Schleiermacher's Life of Jesus, in the Life of Jesus for the German People, $\S$ he was in no position to appraise the profound truth of Strauss's declaration, published one year later, in direct criticism of Schleiermacher's posthumous work.

same work, "Outline of Professor Smith's Intended Lectures on Evolution." These were the Ely Lectures at Union Theological Seminary, which Smith did not live to prepare.

*Henry B. Smith, His Life and Work, Edited by His Wife, p. 124.

$\dagger$ Prose Writers of Germany, Frederick H. Hedge (Philadelphia, 1848). Smith's excursus and translations from Hegel are to be found at pp. $446 \mathrm{f}$. The American Cyclopcedia, article Hegel, Vol. VIII, pp. $607 \mathrm{f}$. This is a model article, admirably informing, and is still of great value. Its exposition of the Hegelian philosophy, however, is external.

$\ddagger$ Cf. Faith and Philosophy, pp. 443 f., where Smith misses the real issues.

§ Introduction-Part I. 
"Without incurring the reproach of self-praise, and almost without fear of contradiction, I can now say that, if my Life of Jesus had not appeared within a year of Schleiermacher's death, his would not have been so long withheld. Till then it would have been hailed by the theological world as a deliverer. For the wounds which my work inflicted upon the theology of that day, it had neither palliative nor dressing. Nay, it displayed the author as in a measure responsible for the disaster, for the waters which he had admitted drop by drop, were now pouring in like a flood, in defiance of his prudential reservations." $*$

Inevitably, then, Smith tends to dismiss rigorous scientific thinking as "materialism," rigorous philosophical thinking as "pantheism"; a procedure that amounts to paying himself with words. For, he tells us that "Providence, and not natural law, controls the course of history and determines the destiny of the race," $\dagger$ unmindful that, whether the one or the other be chosen, the whole problem is then and thereby evaded.

As a consequence, unconscious although both master and pupil may have been at the time, Smith could not face the problems that were beginning to disturb Morris, and his teaching cannot well have lacked a certain air of reality. No doubt, too, the general atmosphere of the Seminary - where, as we are told, these fundamental matters were not taken very seriously by the average student, coupled with temporary preoccupation in

* When Strauss wrote his Life of 1864, he knew Schleiermacher's Lectures on the Life of Jesus only from MS. notes which had been transmitted to him. After the publication of the Lectures, under the editorship of Rütenick, in 1864, Strauss wrote a direct reply-Der Christus d. Glaubens $u$. d. Jesus d. Geschichte; eine Kritik d. Lebens Jesu v. Schleiermacher (1865) - from which I quote.

$\dagger$ Faith and Philosophy, p. 357. An excellent criticism of the defects of the kind of philosophy professed by Smith is to be found in Philosophy and Modern Life, J. H. Hyslop, The International Quarterly, Vol. X., pp. 304-9. 
Abolitionism, Teetotalism, the strife between the 'Old' and 'New' Schools in American Presbyterianism, and so forth, - served to heighten this impression. Morris, having lived through these affairs, could afford to discount them, and had come to feel the need for more elbow-room. So he passed on to Germany where, in his turn, he became a pupil of Smith's teachers, Ulrici and Trendelenburg, who had gained their final standpoint long since and were, in a fashion, representative of a past generation.

As far as it is now possible to give a valid opinion upon these subtle, changing states of mind, it seems altogether likely that Morris was no more than troubled, vexed or puzzled, certainly not in open revolt. And we happen to be aware, from surviving friends, that he plumbed the deeps of scepticism only after return from Germany, and during the first years at Michigan, say, between 1868 and 1873 .

At the outset of his European Diary, Morris informs us that he is reading Hodgson's Time and Space.* His review of this work, published in April, 1867, offers valuable evidence for his state of mind at the close of the Seminary episode, and before he came into contact with German scholarship. It is true that the sidelights are mainly negative. But they serve to show that the full stress was by no means upon him, that he was not in revolt. Besides, they intimate positively that such standpoint as he had was rather theological than philosophical, as, indeed, might be anticipated. Little wonder, then, that the discussion of Hodgson is at once external and based upon dogmatic preconcep-

* Time and Space, A Metaphysical Essay, Shadworth H. Hodgson (1832-1912). 
tions. Morris is quite innocent of the influences formative of his author. He is unaware that Hodgson, a mature man of thirty-three when Time and Space appeared, had been drawn to philosophy by overpowering domestic sorrow, ${ }^{*}$ and therefore approached the subject with emphatic practical bias, which the wistfulness of his work everywhere betrays. His account of the parentage of the book misses the mark widely.

"It contains, in fact, sensationalism, newly worded and newly formalized. Its intellectual parentage is, however, not so much to be traced to such men as Hume and Helvetius as to Bacon and Locke."†

As a matter of fact, Hodgson's fathers after the spirit were Coleridge, $\ddagger$ Ferrier, $\S$ and Kant.\| While his method was that of Hume who, as Hodgson believed, could be outflanked only on his own chosen ground, Morris was also blind to Hodgson's originality, and thus content to dismiss him as a conventional example of the 'insular type of thinking,' hereditary from Roger and Francis Bacon. On the other hand, Morris, still under the sway of Deistic rationalism, accepts the mediæval notion of causation, which Hodgson dismisses for scientific reasons. He also postulates an Absolutemaking this identical with the God of theology, however, - while Hodgson excludes this entity, for ethical reasons.

"The ideas of the good, power, and truth are ideas of the understanding, the subjective aspect of them shows them as

* Cf. The Dedication to his Theory of Practice-“Mortuis Meis."

$\dagger$ The American Presbyterian and Theological Review, Vol. V. (New Series), p. 217.

$\ddagger$ Cf. Hodgson's Dedication to his Philosophy of Reflection- "To Samuel Taylor Coleridge, my father in philosophy, not seen but beloved."

\& Institutes of Metaphysic.

|| "The moral law within" rather than "the starry heavens above." 
ideas of the reason, or modes of reflecting consciousness. . . . When these are considered as united in one Subject, as modes of its consciousness, they form an ideal person, and this ideal person is God."*

Morris is completely impervious to the bearing of an argument of this kind. Moreover, he could hardly be expected to note that Hodgson was a pragmatist long before the first pragmatist in the United States. "From the vanity of speculation there is no refuge but in acquiescing in its relative nature, and accepting truth for what it is." $\dagger$ He might, however, have evinced sympathy for Hodgson's palpitating ethicism. But he does not; thereby intimating that his own problem was a theoretical one and that, meanwhile, he saw no solution for it save in theological ontology. Moreover, he retains one trait distinctive of his youthful outlook-a tendency to stamp intellectual opponents as sources of moral corruption. The characteristic is as unpleasing as Hodgson was undeserving even a hint of the flout. The review, then, is somewhat jejune. Further, and more important, it leaves the impression as of one "whistling in the dark, to keep his courage up."

What we have been able to adduce so far, establishes several points. No matter how strongly Morris may have reacted from its norms of conduct and its theological dogmas, he never escaped the inbred forces of the New England conscience. In minor morals, themselves of little moment, he freed himself so that he tasted something of la joie de vivre; yet, he remained ever a Puritan at heart, with the Puritan eagerness about ethical questions. Similarly, while he drifted from Calvinism, the problem of religion always retained

* Time and Space, p. 574.

† Ibid., p. 588. 
masterful grip upon him. Contact with German culture was not destined to transform, much less to obliterate, his hereditary traits.

So far as I am able to infer, after careful inquiry, European study affected him in two ways principallya positive and a negative. Positively, he learned the necessity for scholarship, and set himself to master the history of philosophy gründlich. Building upon an excellent preparation in the New England schools, he came to possess a fund of philosophical information equalled by few, if any, of his countrymen at that time. The humane spirit of Ulrici, ranging with admirable catholicity the fields of literature, law and natural science, and the thorough, methodical, historical accuracy of Trendelenburg gave him a lead, which he followed up to the utmost advantage when engaged upon the translation of Ueberweg. Negatively, he obtained no system from his German masters. His later struggle with scepticism is traceable, in part, to this, while his evident affiliation with the British Hegelians, after 1880, attests his own consciousness of the need to bridge the gap. Thus, his German residence was of the utmost importance in that it enabled him, a decade later, to revert to the great Idealists at first hand, and with definite knowledge of the issues. Yet, it was an element in his preparation only. For, at the moment, so far from easing his doubts, it merely punctuated his years of transition. Let us consider the situation briefly.

When Morris arrived in Halle, Ulrici was a man of sixty, his best work done, all his hostages given to fortune. At Berlin, a year later, he found in Trendelenburg a teacher of European reputation who had but five years to live, whose greatest book had been before the public 
for nearly a generation. Thus, his choice of professors, controlled unquestionably by Smith, was lucky and unlucky. Lucky, because the break between the Yankee and the Teutonic environments was neither so violent nor radical as to induce anything in the nature of a complete overthrow. Unlucky, because the issues in which his teachers had won their spurs were becoming what Germans call 'overpassed standpoints,' and being replaced by others, particularly those connected with rising Neo-Kantianism; while, too, the leadership of the important group to which Ulrici, Trendelenburg and Ueberweg belonged, in a mediating type of thought, foot-loose from thoroughgoing system, had been challenged successfully, because with a system, by a greater than they-in the person of Lotze.* As a consequence, Morris escaped with himself, so to speak, for the reason that he did not come under the spell of a potent, seminal personality. Ulrici, although a rarely accomplished man, followed his age, never led it; and Trendelenburg, while a historical scholar who gave place to Zeller alone, was an organizing and administrative far more than a spiritual power. He left the deeper mark upon Morris, but was a secondary, not a primary force. Thanks to him, the pupil was enabled to enter the difficult company of the Fachgenossen, not persuaded to re-orient his whole being.

For better or for worse, Morris found German thought well started upon that long period of transition which, beginning about 1840, still continues. But the personnel of his teachers and friends was such that the

* This may be dated from the year 1857, when Lotze published his Streitschriften, a powerful but courteous polemic-when courtesy was all too little characteristic of German polemics-upon I. H. Fichte, with whom Ulrici was closely and Trendelenburg partially affliated. 
anti-philosophical implications of the movement, destined to gain ground steadily after 1870 , were concealed from him. On the other hand, probably without realization of the fact, he was wafted back to the prescientific stage, when humanistic problems-critical, literary and theological-predominated, but when, at the same time, confusion had succeeded confident system-making. Although the epithet fails to cover all the factors, we approach the truth if we say that he fell into the Neo-Fichtean circle; and this was eclectic, except in so far as it developed too soon for due appreciation of the rigour and vigour of modern natural-scientific methods, with their attendant presuppositions. Abjuring Hegel, even to the extent of unmannerly petulance* or of tripping by verbal catches, $\dagger$ this group was nevertheless controlled by him, willy-nilly. For, its parade of appeal to "experience" took the form either of an objective 'psychologism' or of a historical 'criticism' alike impossible without his "substantial thoroughness, which penetrated to the background of things." $\ddagger$

While the activities of Liebig about 1826, and those of A. von Humboldt immediately afterwards, gave natural science a position unparalleled in Germany since the Wars of Religion, it was not till the discoveries of Schleiden and Schwann (1838-9), and especially of Virchow and Helmholtz ten years later, that the realistic reaction gathered irresistible force. Thanks to Schelling and his disciples, among whom were many important

* Cf. Ueber Princip u. Methode d. Hegelschen Philosophie; ein Beitrag z. Kritik derselben, H. Ulrici (1841).

$\dagger$ Cf. Logische Untersuchungen, Bd. I., pp. 22 f. (1840), and Die logische Frage in Hegel's System (1843), A. Trendelenburg.

$\ddagger$ Zur Geschichte d. neuesten Theologie, Carl Schwarz, p. 29 (3d ed.). 
men of science,* Vitalism held sway, and Ulrici in particular availed himself of it, to palliate difficulties. Unfortunately, too, as we still have good reason to know, the early votaries of biological inquiry, misled by the mechanical generalizations of the seventeenth and eighteenth centuries, rushed $\cdot$ headlong into a popular philosophy so jejune that it was soon fated to fall an easy prey to the assaults of Neo-Kantianism. Thus, instead of appraisal of the logical methods of science, or of sober examination of its necessary metaphysical assumptions, philosophical activity took the shape of an attack upon Materialism, no formidable enemy. Ulrici and Trendelenburg were involved in this also, although in the preliminary phases of the conflict only. $\dagger$ Probably for this reason, the latter does not appear to have grasped the essentially epistemological character of his contribution to pure philosophy, nor did Morris suspect this at the time. Further, as with Smith, so with his and Morris's teachers, the sensation produced by the Hegelian left, especially by Strauss, wrought sad havoc upon balance and objectivity. For example, blinded by temporary panic to the meaning of the axiom, "The genuine critique of dogma is its history," $\ddagger$ they preoc-

* Cf. My The Anarchist Ideal, pp. 145 f.

$\dagger$ It is well to be on one's guard against the judgment of Fortlage, which was written too early to be of significance for modern science, He says: "It is important to notice that natural science, as it now exists, is extremely favourable to Trendelenburg's doctrine, to such a degree, that this doctrine may be termed the last and complete consequence drawn from the present state of natural science" (Genetische Geschichte d. Philosophie seit Kant, p. 449.) The date is 1852 , and the reference is to Trendelenburg's doctrine of Space and Time, best remembered in connection with the notorious Kuno Fischer controversy. The intimate alliance between Evolution and eighteenth century mechanicalism was still to come.

$\ddagger$ Die christliche Glaubenslehre in ihrer geschichtlichen Entwickelung 
cupied themselves, philosophically, with the question, "Whether a middle way can be discovered."* Their emotions aroused by the onslaughts of Strauss and Feuerbach upon 'sacred theology', they quailed before the philosophical problem and, making the Absolute transcendent, at the same time made Him(!) unknowable.

Yet, tossed about by many winds of doctrine as Morris must have been, one solid plank, floating amid the wreckage, afforded him temporary refuge at least. We have seen that he learned the virtue of historical accuracy from Trendelenburg. But this was not all. Led, no doubt, by the revived study of Plato, exemplified in Schelling and Schleiermacher, Trendelenburg passed on to Aristotle, in whose philosophy he found something stable-a classical surety as compared with romantic vagaries. He says memorably, in a passage quoted often since,

"The prejudice of the Germans must be abandoned that, for the philosophy of the future, a new principle had to be discovered. The new principle has been found; it lies in that organic conception of the Universe which has its foundation in Plato and Aristotle, and which, continuing from them, will have to complete itself in a profounder examination of fundamental ideas, and through an interchange with the science of reality." $\dagger$

- He implies that there are several ways of possible interpretation of the universe. After the manner of natural science, we may hold that there are no causes except efficient causes, to the exclusion of final cause; a view which he chooses to associate with Democritus. We may contend that efficient and final causes are u. im Kampfe mit d. modernen Wissenschaft dargestellt, D. F. Strauss, Bd. I., p. 71 .

* Ibid.

$\dagger$ Logische Untersuchungen, Bd. I., p. ix (2d ed.). 
substantially identical, as he alleges Spinoza to have taught. We may discern that "the principle of design or final cause" so operates as to transform efficient causes into effects-the "ancient philosophy." The last is the "organic conception of the Universe which has its foundation in Plato and Aristotle." It may be said in passing that this theory afforded a certain solution of one problem, urgent for the theologically minded Morris-miracles. For, identify your final cause with God, and a miracle becomes an efficient cause, authenticating a revelation because attesting it through 'facts' (i.e. events), perceptible to normal men. But to return. Seeing that motion in the physical world and motion of thought are the two species of "activity disclosed to us through sensible experience," Trendelenburg solves the problem of the relation between Thought and Being by means of a peculiar theory of this common element, and arrives at metaphysical conclusions very similar to those of Schleiermacher, made familiar to Morris by Smith. Consciously or not, another member of the same school states Schleiermacher's doctrine in such a way that, with little or no essential change, the summary might fit Trendelenburg.

"He teaches that in every kind of thinking the activity of the reason can be exercised only on the basis of outer and inner perception, or that there can be no act without the 'intellectual' and none without the 'organic function,' and that only a relative preponderance of the one or other function exists in the different ways of thinking. Agreement with existence is immediately given in inner perception, and is attainable mediately also on the basis of outer perception. The forms of thought, notion and judgment, are made parallel, by Schleiermacher, to analogous forms of real existence-the notion to the substantial forms, and the judgment to actions."**

\footnotetext{
* System of Logic and History of Logical Doctrines, Fr. Ueberweg,
} 
It is important to note that Morris seems to have fallen back upon this type of theory during the middle seventies, just after the struggle with scepticism had virtually ended. Nor is this strange. The idealrealism of the Neo-Fichteans, with its earnest Theism, could be grafted readily upon the New England conscience. Moreover, the moral interest, warm in Ulrici, magisterial in Trendelenburg, with its strong tendency to find the basis of metaphysics in ethics, cannot but have been grateful. As Trendelenburg declares,

"It has been proved by Kant that pleasure cannot be regarded as the motive of the good will. In that case the motive would be self-love. But Kant has not proved that pleasure is excluded from virtue and that nevertheless the reason may enter in, as if by a back door, and claim happiness as the reward of virtue, in the realm of actual praxis. In the direction of Aristotle is found a principle which is not swallowed up by pleasure, but which makes pleasure one of its own results."**

Such teaching might well serve to broaden and humanize the Puritan outlook, without in any respect undermining it. Nevertheless, Morris's marked copy of Bratuschek, $\dagger$ together with some remarks in his essay upon Trendelenburg, show that he must have been acquainted with the eclectic character of his master's philosophical work; and he could hardly fail to arrive at the conclusion that, of the many sources from which it is pieced together, some are incompatible. Thus, although resting on the theory for a time, as the Victoria Institute addresses indicate, he turned from it when he began to think for himself.

Eng. trans., Thomas M. Lindsay, p. 70. For a good summary of Trendelenburg's philosophy, see Philosophische Propdeutik, Jos. Beck, Part II.

* Historische Beiträge z. Philosophie, Bd. III., p. 213-4.

† Cf. Adolf Trendelenburg, Ernst Bratuschek (1873). 
On the whole, then, apart from the indispensable ploughing and admirable discipline secured from his German professors, the continental experience appears only to have prolonged the period of transition and, perhaps, to have delayed the attainment of self-mastery.*

Turning now to the period of scepticism; we should recall at this point, that other movements, facing forward rather than looking backward, had become powerful, sometimes vociferous, in Germany, during the generation that intervened between the Wanderjahre of Smith and Morris. In respect to method, Trendelenburg represented one of these, while Ulrici embodied a phase which, however important, was waning rapidly. But, whatever their leanings might be, like German professors, they concealed nothing; they had no use for an index expurgatorius. Moreover, Morris was an omnivorous reader. Accordingly, despite the temper of his academic instruction, he inevitably came into contact with the larger sweep of nineteenth century thought, nowhere more unchecked than in Germany. Besides, these newer ideas possessed impressive consentaneity; all appeared to head in the same direction. Uncertainty, the gradual ebb of idealism, absorption in detail to the eclipse of significant issues, Irrationalism, Materialism, and so forth, combined to induce doubt. Even had he so desired, Morris could not blink the facts.

In the first place, starting with Hamann, who saw in history - the Old and New Testaments being but incidents-the Geschichtlichwerden of the Divine, Germany had taken her place as the classic land of the victories but, no less, of the wounds of the critical method.

* I have not deemed it necessary to discuss the article on Trendelenburg, which confirms this view emphatically. 
This method, dominated at the time, and in the studies which drew Morris, by the Tübingen School, inculcated absolutely free inquiry, provided there were a solid basis of minute, specialized study. But it also taughtand here lay its salvation- "that, however rich the details may be, no single feature as such has any value; but only if it is placed in the whole and considered as a moment in the process of the general idea which governs everything."* This amplitude of outlook was dependent however upon the great Idealist systems which ruled from 1800 to 1840 . Thus, although the method led men to write religion, philosophy or literature, as the case might be,-not about religion, philosophy or literature,-it was destined to fall away when these systems lost control, and to be supplanted by an ingenuity or analytic erudition that had no hope of success save in minutice of investigation. A group of scholars appeared, many of whom 'could not see the wood for the trees.' As Nietzsche said, in revolt against his philological training,

"My memory - the memory of a scientific man, if you please!teems with the naĩvetés of insolence which I have heard ... from ... the specialist and the Jack Horner who instinctively stood on the defensive against all synthetic tasks and capabilities." $\dagger$

Moreover, while, in its first generation, the critical spirit had been steadied by religious conviction, this was receding quickly before philological, economic or naturalistic interests. Truth was becoming so salted that it could not slake man's spiritual thirst; to such a degree, indeed, that, lacking other synthesis, even the

* Carl Schwarz, op. cit., p. 149.

$\dagger$ Beyond Good and Evil (Eng. trans.), p. 134. 
rhetoric of Renan could be welcomed-or anathematized -as 'science'! And Morris appears to have thumbed the Life of Jesus (1864).

In the second place, the spokesmen of the premature generalizations that marked pre-Darwinian science, had had their clamorous say. Vogt (1847); Moleschott (1852), and Büchner (1855) had contrived to hypnotize multitudes. The political unrest of 1848 had been followed by a parallel jeopardy of religion, of ethical values, of sober scientific accuracy. Nor could Morris extract reassurance from the outburst of Irrationalism in philosophy, as Windelband has aptly baptized it. The last phase of Schelling, the anarchism of Feuerbach, the 'amalgamism' of Hartmann-hotch-potch philosophers, spiritual rat-catchers, misleaders, in Nietzsche's lambent epithets-enlightened on the lucus a non lucendo principle. Further, the vogue of Schopenhauer, just after his death, in 1860, was another straw, showing how the wind blew. Here, again, Nietzsche laid the situation bare with keen scalpel.

"In fine, I found most frequently, behind the proud disdain of philosophy in young scholars, the evil after-effect of some particular philosopher, to whom on the whole obedience had been foresworn, without, however, the spell of his scornful estimates of other philosophers having been got rid of - the result being a general ill-will to all philosophy. (Such seems to me, for instance, the after-effect of Schopenhauer on most modern Germany: by his unintelligent rage against Hegel, he has succeeded in severing the whole of the last generation of Germans from its connection with German culture, which culture, all things considered, has been an elevation and a divining refinement of the historical sense: but precisely at this point Schopenhauer himself was poor, irreceptive, and un-German to the extent of ingeniousness.)"**

${ }^{*}$ Ibid., pp. 134-5. 
Moreover, Germany was about to take service under the banner of F. A. Lange* and his disciples, who oscillated between two poles, upholding, on the one hand, a form of subjective idealism, in reply to Materialism, on the other, succumbing to the positivist implications of scientific naturalism. "The philosopher's harmonious image of the universe is a sheer illusion; and, for philosophers of the school of Lange, it is a conscious illusion." $\dagger$ This is indeed "gray in gray," with no apparent escape except that offered by Hume.

"I am first affrighted and confounded with that forelorn solitude, in which I am plac'd in my philosophy, and fancy myself some strange uncouth monster, who not being able to mingle and unite in society, has been expell'd all human commerce, and left utterly abandon'd and disconsolate. ... . Most fortunately it happens, that since reason is incapable of dispelling these clouds, nature herself suffices to that purpose. . . . I dine, I play a game of backgammon, I converse, and am merry with my friends; and when after two or three hours' amusement, I wou'd return to these speculations, they appear so cold, and strain'd, and ridiculous, that I cannot find in my heart to enter into them any farther." $\ddagger$

But, whatever the stress, the New England conscience barred this path.

Finally, Darwin had come, producing a fermentum cognitionis equalled in the modern world only by Newton, Kant and Hegel. Morris probably knew little or nothing in detail of the evidence for the conclusions of the English "all-destroyer." Yet, no more than his neighbours, could he escape the drift, not of Darwin, but of the popular Darwinian movement. The older criticism,

* Cf. The History of Materialism (1865), Eng. trans., 1879.

$\dagger$ Cf. Hartmann, Duhring u. Lange, H. Vaihinger, pp. $191 \mathrm{f}$.

$\ddagger$ A Treatise on Human Nature, Vol. I., pp. 544, 548-9 (ed. T. H. Green and T. H. Grose). 
still vital in Ulrici and Trendelenburg, had been an appreciation of religion, literature, morality and institutions, in short, of life in its broadest interpretation. And, although it had gradually forsaken study of individuals-"all history is biography"-in favour of the delineation of vast mass-processes, it had been confident, nevertheless, of its capacity to uncover origins, to trace genetic movements. But now, disillusion was to supervene, because the Whole, disappearing in the maze of the parts, the search for origins was doomed to become a description of an unending process, without ascertainable beginning, without discernible end. Scepticism or agnosticism in the theoretical life, pessimism in the practical, had found an unexpected-for of all this Darwin was quite guiltless-but, none the less, potent ally.

Surrounded by these influences, which were permeating everywhere, and posing as 'the last word'; the check and guidance of teachers withdrawn; bereaved in his home; disappointed in love; unable to find a niche in the American educational system, Morris passed through the fire of doubt. But he consumed his own smoke to such purpose that, save for confidences imparted to one or two friends, he left no evidence of the trial through which he went between 1868 and 1873 . We know that it drove him in upon self, to such an extent as to affect his personal relations with others, even with his young students, who judged him strange or 'queer.' "The rest is silence."

The translation of Ueberweg, begun immediately after repatriation, must have done Morris a real service, by affording him distraction. It certainly solidified his scholarship and confirmed him in German methods 
of critical Wissenschaft. Subsequent publications, between 1874 and 1877, when a silence of three years ensued, indicate that, after the sceptical digression, he was inclined to fall back upon Trendelenburg, although the papers, Philosophy of Art and Immortality bear traces of Neo-Fichteanism and Ulrici. The criticism of Taine's The Philosophy of Art shows too, even thus early, a strong reaction against positivist teaching. Further, in all likelihood, this also serves to explain the occasion of two of the three important articles written during these years-The Final Cause as Principle of Cognition, and The Theory of Unconscious Intelligence as Opposed to Theism; the third was Friedrich Adolf Trendelenburg. The former were sent to London by Morris, in his capacity as an Associate, and read before the Victoria Institute.

This society had been founded through the efforts of James Reddie, an official at the Admiralty Office, and Captain (afterwards Vice-Admiral) E. Gardiner Fishbourne, who became respectively the first secretary and the first treasurer of the organization. After preliminary efforts, continuing over more than a year, the initial meeting was held on 24th May, 1866; the society exists still. I am bound to confess that, despite some familiarity with the learned societies of Great Britain, I had not heard of this one till I undertook the investigation of the Morris papers. Nor am I altogether blameworthy, for, so far as I can discover, the membership has never included the foremost leaders of British intellectual activity.* At the same time, the Institute is not to be classed with those obscure juntas, whose insinuating

* Till 1884. I am not informed as to its membership or activities since. 
leaflets one receives every little while, devised for the purpose of filching fat annual subscriptions from unsuspicious Americans. The interesting and, for our present subject, significant fact is, that it came into existence under special circumstances, for a definite purpose, as may be learned from the constitution and the asseverations of founders.

\section{Among its objects are those:}

"To investigate fully and impartially the most important questions of Philosophy and Science, but more especially those that bear upon the great truths revealed in Holy Scripture, with the view of defending these truths against the oppositions of Science, falsely so called. ... To examine and discuss all supposed scientific results with reference to final causes, and the more comprehensive principles of Philosophy proper, based upon faith in the existence of one Eternal God, who in His wisdom has created all things very good."*

The original circular, issued in connection with the preliminary canvass (1865), states:

"In fact, the Society will be organized for the purpose of applying to 'science' somewhat of that vigilance to detect its errors, contradictions, and fallacies which has been freely enough exercised in our day upon the statements of the Scriptures and of Christian doctrine, by those who accept, without the least actual examination and with an almost absolute credulity, all that passes for science." $\dagger$

Reddie, the moving spirit, declares:

"The great object of the Victoria Institute . . . is to defend the revealed truth of Holy Scripture against oppositions arising, not from real science, but from pseudo-science; and this is an object which no previously existing scientific society has made its aim. ... It may be regarded as simply notorious, that

* Journal of the Transactions, Vol. I., p. vi.

$\dagger$ Ibid., p. 31. 
Science, so called (whether truly or not), is considered by many persons to be at issue with what had been regarded (whether truly or not) as truths revealed in Holy Scripture. This supposed contradiction between science and the Scriptures was most boldly put forward in the 'Essays and Reviews,' as a ground for rejecting the theory that the Scriptures are wholly inspired; and Dr. Colenso and others have followed in the same path, publicly alleging the existence of such contradictions, and, so far with a bold consistency, setting aside the Scriptures, in consequence, as false. . . . It should be kept in mind that the Victoria Institute, as a matter of fact, originated as a defense movement."*

The Inaugural Address of the Vice-President, the Rev. Walter Mitchell, opens with this pronouncement:

"No one who watches the expression of thought by the cultivated intellectual classes of this country, through its literature, can deny that the opinion that science and revelation are directly opposed to each other has been spreading with fearful rapidity." $\dagger$

Of course, Baden-Powell, Lyell, Darwin, Tyndall and Büchner receive due castigation, in the name of the argument from Design!

"The Noble Earl" (Shaftesbury), the first President, remarked, in a speech delivered after the inaugural dinner:-

"The Institute would be of the utmost importance to those who had no means of access to the answers given to the deleterious nonsense published under the name of Science. . . . Some conceived in malignity, some in ignorance, and some in mistaken notions that they were adding to the general science of mankind." $\ddagger$

Here are keynotes to "fully and impartially" investigating "the most important questions of Science," in

* Ibid., pp. 5, 6, 9. The italics are mine.

$\dagger$ Ibid., p. 45.

$\ddagger$ Ibid., p. 80 . 
the name of "the more comprehensive principles of Philosophy proper"!

"I venture to say that neither Dr. Colenso, nor any sceptical geologist on his behalf, can point to a single geological fact, or even to any respectable theory entertained and taught in any geological work now extant, which any great number of geologists would say they accept, that can in the least be considered as contradictory to the Mosaic account of the creation. ... I have alluded to Halley, Laplace, and other atheists, infidels or unbelievers, who have no doubt been glad to find what they considered to be scientific contradictions of God's Revealed Word."*

In short, we have a body of highly respectable gentlemen, quite innocent of philosophy after Kant and of theology after Schleiermacher, almost as innocent of science after Lyell, Helmholtz and Darwin, who, stung by the 'scandals' of the moment, in Essays and Reviews and Colenso, proposed to save the fabric of religion by reverting to eighteenth century apologetics with all its brood of pitiful misconceptions. How English! To be natural and revealed theologians in the same breath! One is almost persuaded to embrace the hilarious half-truths of Heine.

"In discussing politics, the stupidist Englishman will always contrive to say something rational; but whenever the conversation turns upon religion, the most intelligent Englishman will exhibit nothing but stupidity."

Happily, we are not concerned here with the most intelligent Englishmen of that time.

And Morris? Que diable allait-il faire dans cette galère? I imagine that, at first, he did not appreciate the inwardness of the situation. For, we are aware that "he was persuaded to join the Institute by an English

* Ibid., pp. 15, 24. 
friend." But, as he possessed a set of the Transactions from the beginning, he must have become acquainted with the tendencies of the association. Accordingly, we are bound to infer that his coopperation marks his rebound from scepticism, and his reversion to the mediating theories of his teachers. The signs of transition are written large. Here was a field for "ideal-realism" which, in the name of religion, "starts with a measuringrod that is not that of religion." But such a phase could not last. We find that Morris disappears from the list of members after the Transactions of 1882-3, when his set ends.

The essay on Final Cause is reminiscent of the NeoFichteans. We are referred to Trendelenburg, I. H. Fichte, and Ulrici-whose Gott und die Natur would, Morris thinks, "if translated into English, subserve most efficiently the ends which the Victoria Institute proposes to itself."* The problem under consideration is:

"To see whether the ideal-thought-is also actively present in the real, as a principle underlying and controlling it-more especially in the form of final cause. The question is a metaphysical one, in so far as it relates to our judgment of the real constitutive nature of the so-called 'real' objects in the world, or of the world in general; and it is a logical one, or a question belonging to the theory of cognition, in so far as it is connected with the complex of propositions which we are compelled to hold as true regarding the conditions and forms of human knowledge. The answer to the metaphysical question will depend upon the answer to the logical one." $\dagger$

The paper resolves itself into a judicious attack upon the subjectivism of Kant, and the premises of contemp-

* P. 16 , note.

$\dagger$ P. 5. 
orary sensationalism and materialism. Final cause and freedom are to be proven

"by an inductive appeal to our own consciousness and to that of others-i. e., by direct personal observation and experience we arrive at the assertion of freedom. The denier of freedom, on the contrary, proceeds from some such general truth as that of law in human actions, whence he deduces a conclusion in conflict with our induction."*

A certain amount of assistance is derived from the nescience of such naturalists as F. Schneider and E. Du Bois-Reymond. The method is essentially that of Trendelenburg; "we proceed by the way of analogy, arguing, as far as there seems ground for it, from the known to the unknown." $\dagger$ At the same time, one must insist that Morris, while traversing the metaphysics of mechanical monism, very frankly accepts all the facts of science, so much so that, in the discussion of the paper, he was charged with neglect of "the being and existence of God, and the Bible record." In a written reply, forwarded by him later, he answers this typical sciolism acutely, saying:

"I made no use of scriptural arguments since, had I done so, I should have begged the question I wished to prove. He who accepts Holy Scripture and Christianity admits, necessarily, the doctrines of God's existence, of creation, of Providence, and of the soul's immortality. He admits, therefore, that nature is controlled by and has its origin in intelligence." $\ddagger$

Morris thus lays his finger upon the fundamental weakness of the position occupied by the society he was addressing. Further, he adds, lifting a corner of the veil from his own sceptical trials:

*P. 8.

$\dagger$ P. 11.

$\ddagger$ P. 30. 
"My paper was designed to aid those who deny or honestly feel that they cannot intelligently admit the philosophical truth of the Bible. There are, as I know by experience, thinking minds so entangled in the idea of nature as an original entity, working with blind, mechanical, resistless power, and of man as but a product and part of this natural mechanism, that they see no possibility of the truth of the doctrines of God's existence, of Divine Providence, and of human freedom."*

What we have, then, is a thorough mastery of the materials gleaned from German teachers with, as yet, no decisive indication of independent conclusions.

The paper on The Theory of Unconscious Intelligence is of less moment. As the title implies, it offers a criticism of Hartmann's Philosophy of the Unconscious, then beginning to attract notice in England. There is a competent historical introduction, emphasizing the primacy of Aristotle in the spirit of Trendelenburg, and, after Ueberweg, suggesting the influence of Leibniz upon the Cambridge Platonists. It is interesting to observe that, when he comes to recent writers, Morris retains the inimical attitude towards Hegel, one of the least fortunate among his German acquisitions.

"Of the Hegelian system, Dr. Volkelt, himself an Hegelian, reaffirms the most common interpretation, namely, that it represents the universe as the gradual evolution of an unconscious, ideal principle ('the unconsciously logical,' as Volkelt very abstractly terms it), which attains to self-consciousness only in man (and most perfectly, it may be presumed, in Hegelians of the school of Volkelt.)" $\dagger$

This is one of the very rare occasions on which Morris forgets "to use the language of those who can afford to respect others because they respect themselves." The

* Pp. 30-1.

† P. 17. 
critique of Hartmann, while sharp, is surprisingly tolerant. And Morris feels the difficulties so keenly that he is forced at one point into something suspiciously like panpsychism.

"Atoms, whatever else they may be, have, as I believe, an ideal or spiritual aspect, which is their fundamental and controlling one; and all force is reducible to will-power. This involves the 'imputation to atoms of a germ of consciousness.' As compared with man, they are unconscious. But implicitly and germinantly they are conscious."*

The discussion, which ensued, shows how little German thought had succeeded in penetrating England.

"We must remember that this theory of an unconscious intelligence at the head of the universe is now agitating all the mind of Germany. We must not try to persuade ourselves that a theory, which has occupied an intelligent nation persistently for the last twenty years, is one in which there is absolutely nothing worthy of consideration. ... The present paper, however, contains some expressions which I am afraid some English readers will find it difficult to appreciate, especially as we have not been much accustomed in this country to the study of metaphysics. . . . I found some considered that it was really a wonderful work, whilst others were of opinion that it was disgraceful; and I cannot help mentioning a remark made by a young friend of mine at Heidelberg. . . . He said, 'If I wanted to make money, I should write a book on the greatest absurdities I could think of, and it would be bought by every German.' Now, I cannot help thinking that Hartmann has succeeded to a certain extent in carrying out my young friend's ideas." $†$

This being the atmosphere, the fate of Morris's panpsychist suggestion was sealed.

"Such a statement is utterly subversive of all chemical knowledge." $\ddagger$

* P. 36.

$\dagger$ Pp. 38, 43.

$\ddagger$ P. 42 . 
Again following Trendelenburg closely, Morris replied:

"Absolutely inert matter would be a substance which does nothing, which has no power. . . . From the point of view of positive science, it is also false, since science knows nothing of matter apart from force. . . . How the force called 'chemical' is related to conscious will, I cannot exactly state. I maintain only that an exhaustive and exact analysis must end by tracing it back to the intelligent will and power of a personal God."*

We may say, then, that both papers are excellent examples of criticism and evince sound scholarship. But beyond a tendency to stress certain beliefs associated with the theology of Christian orthodoxy in Protestantism, they fail to exhibit constructive thought. Moreover, they are singularly swayed by the controversies of the moment, with disadvantage to objective treatment of the larger philosophical questions that necessarily obtrude themselves. To adopt Schelling's phrase, Morris objected strenuously to theories which made nature godless; but, no less, when countering them, he was still a victim of the opposite fallacy, whereby God is made unnatural.

I am far from thinking that the period of transition ended definitely with the Spinoza article (1877); this is not only full of very cautious praise of such a genius upon such an occasion (the two hundredth anniversary of the death), but it reduces itself to a running commentary, however competent in its way, upon the Ethics. Phases in a man's mental development are not to be cut off from each other as with a hatchet. The fact is, that a reaction from scepticism cannot be identified with an 'awakening from dogmatic slumber.' Moreover, individuals pay their debt to their age. And there

*Pp. 45-6. 
was no profound philosophical ferment in the United States. Such theological troubles as came to the surface tempted many to view fundamentals as 'too high for them,' as inscrutable; thorough discussion lay under a certain ban-did it not savour of presumption? Nay, Morris's articles, as we have hinted, favour the Mephistophelian intimation,

"Verachte nur Vernunft und Wissenschaft, Des Menschen aller höchste Kraft. . . .

So hab' ich dich schon unbedingt,"

more than the plangent assurance, "The hidden Being of the Universe has no power in itself that could offer resistance to the courageous effort of Wissenschaft."* In a word, farther reflection, and greater emancipation from the leading-strings even of excellent masters, were necessary ere Morris could come to his very own.

*Werke, Hegel, Bd. VI., p. xi. It should be noted that Morris's approach to Hegel was widely different from that of the founders of The Journal of Speculative Philosophy; cf. American Thoughi from Puritanism to Pragmatism, Woodbridge Riley, pp. $240 \mathrm{f}$. 


\section{CHAPTER VIII}

\section{Intellectual History. The Final Stage}

When Mr. Andrew Campbell who, as we have seen, had every opportunity to keep in close touch with him during the period of the philosophical professorship, informed me, several years ago, that Morris did not undertake exact study of the Kantian succession, Hegel particularly, till after 1877, I was frankly incredulous. But examination of the evidence has forced me to conclude that Mr. Campbell was substantially correct.

The undergraduate course of 1860 favoured the classical almost to exclusion of the modern languages. Socrates and Plato, Cicero and Lucretius loomed large upon the academic horizon. On the other hand, German was a terra incognita, French a subordinate and, therefore, elementary study. In addition, the influence of Locke after Jonathan Edwards, and of the Scottish school for sixty years after 1820 , led even professed philosophical students to concentrate upon English and-almost unconsciously - to neglect German authors. It is true that the Cartesians obtained some small recognition, but rather for their relation to British thought than for their own sakes, while Leibniz, if known at all, was read in the Theodicy, in certain respects his least characteristic work. Briefly, scientific history of philosophy had no existence. For example, the notion of Kant to be derived from Dugald Stewart did duty as knowledge with many!*

* Cf. Scottish Men of Letters in the Eighteenth Century, Henry Grey Graham, pp. 425 f. (2d ed.). 
Again, from entrance to Union Seminary till after return from Germany, Morris came into contact with men set in authority who happened to be in strong, sometimes panicky, reaction against the conclusions of the single group of thinkers who enable the modern world to hold up its head with the Greeks. The patent inference is, that he was persuaded to accept criticism upon them in place of the original works.* His situation may be illustrated by a parallel instance, belonging to and characteristic of a later period, involving thinkers of the type of Spencer. A friend of mine, in the late nineties, was assured by an acquaintance; 'Herbert Spencer is an atheist.' He inquired: 'Upon which of his works do you base that opinion?' The answer was: 'I have not read any of Spencer's works, but I am told so, besides Sword and Trowel † says so.' It is absurd, of course, to suppose that Morris ever was in such parlous case. Nevertheless, the influences that surrounded him conspired to obscure the main results of constructive philosophy. In Germany, moreover, he found the ancients set upon a lonely pedestal by Trendelenburg, deepened his acquaintance with Plato, and came to realize the importance of Aristotle. On the contrary, he saw Kant and, even more, Hegel, through the deceptive atmosphere of controversial criticism, thickened by the dust of political and theological strife; this, too, at a moment when the protagonists in the lists had good reason to exclaim, each to every other:

* Cf. B. Croce in What is Living and What is Dead in the Philosophy of Hegel, at the close. The warning is still needful. A professor in occupancy of an important philosophical chair, who was accustomed to spend much time in flouting Hegel, told me once, that he had tried to read Hegel, but could not understand him, and had 'given it up as a bad job.'

† The organ of the late Mr. Spurgeon. 
"Zounds! I was never so bethumped with words, Since first I called my brother's father 'dad' !"

The forces of monistic naturalism, originating with the eighteenth century philosophes of France, gathering momentum from the German materialists of the middle nineteenth century, and sweeping the English world in the activities of the anti-theological missionaries of Evolution, brought Morris to his knees after 1868. He felt the need of supports keenly. But, preoccupied with exacting duties as a teacher of modern languages, he fell back, as might be expected, upon the mediating positions of his German teachers. In this connection, far more than for their philosophical competence, the Victoria Institute addresses possess real significance. They enable us to splice the loose ends. The important passages are as follows:-

"In the acquisition of knowledge we proceed from the known to the unknown, from the sign to the thing signified, and (quite generally) from the part to the whole. Moreover, if knowledge is for us possible, it is, of course, so only under the conditions inherent in our nature and in the nature of real things. It is because man is a part of nature, that he may a priori assume a fundamental likeness between what is essential in his own nature and what is essential in the world around him. . . . The distinction between real and phenomenal needs to be carefully stated, by definition of the terms employed, since it is by no means an obviously fundamental one. All that is, appears; strictly speaking, we know only how the object known appears to us, and in this sense it may be said that all our knowledge is of the phenomenal. . . . But the (conscious or unconscious) employment of the appropriate logical processes leads us nevertheless to distinguish between the real and the phenomenal, and to recognize in the distinction the expression of a fundamental verity. By knowledge of the real I mean knowledge of the essential, constitutive nature of the object of knowledge, of the 
true, noumenal cause, or metaphysical knowledge. All other knowledge relates to what I understand by the phenomenal, hence to what is non-essential, not constitutive, and to effects or phenomenal causes, rather than true causes. . . . Scientific laws of natural action, learned through observation, are laws of so-called mechanical sequence. ... The laws of such action are laws of phenomenal sequence, and not of causation. Socalled mechanical causes are not true causes."*

"I maintained, and still maintain, that what knowledge we possess of spirit is more original and absolute than any fancied knowledge we may seem to have of matter, however incomplete the former may be; and, further, that our ideas concerning matter are hypothetical (as every philosophical scientist admits), and must be framed, in as far as we attribute to matter any substantive existence at all, after the analogy (near or remote) of that which we directly know of ourselves as spiritual entities. . . . Our ' chemical knowledge,' it is quite true, is 'up to a certain point, unquestionable.' But it is so only within the limits which circumscribe all phenomenal knowledge. It is 'unquestionable' in all that it affirms concerning the appearances of things and the laws of their action, in as far as these laws are open to sensible observation. But it quits its proper sphere, and is abolutely valueless, when it is made the principle or only basis of inference concerning the intrinsic nature of things. . . . The error of scientific men too generally is, that they identify the results of their investigations in the region of the phenomenal with knowledge of the real. All positive science which is duly confirmed by observation comparison, and experiment, is to be accepted as true. But this true science of the phenomenal is not to be confounded with science of the truly real, or of the true cause, the underlying truth of the real. I repeat these words as conveying a lesson suggested by the present discussion. I would only add a reference to Aristotle, Metaphysics, xi., 6, 12, where a wholesome warning is expressed against seeking in the reports of our sensible experience a criterion of ontological truth. Stripped of the local coloring which they receive from the idola of Aristotle's pagan mind, the words of this master contain a truth at once old and new, and worthy never to be forgotten." $\dagger$

* Final Cause, pp. 4, 5, 18.

$\dagger$ Theory of Unconscious Intelligence, pp. 45, 46, 47 . 
The emphasis here laid upon the inevitable collision between natural science and spiritual aspiration, is pushed very nigh the point where an opposition within experience becomes irremediable, producing an external separation or dualism between intelligence and belief. For this reason, Morris does not wave science aside. He takes the simple course of staking off a claim for it. As for the spiritual aspirations, however, they must find satisfaction in that "solemn shadow-land of unchangeable ideas," the Unconditioned. The implicit tendency is to view the antithesis between the noumenal and phenomenal as if it were fixed. Hence, Morris comes perilously near that most dangerous of dangerzones, where the antagonisms of experience are accepted seriatim, almost as irreflective consciousness accepts them, and are, therefore, left without a rational principle of internal unity. At best, following Ulrici, he seems to fall back upon the law of Causality - a category of distinction between act and activity. Natural law and mechanism, human freedom and divine final cause, are maintained equally. But the terms turn out to be so concrete on the one side, so abstract on the other, that, when it comes to conflict, the former find easy acceptance, thanks to the adequacy of the senses, the latter meet insurmountable barriers, thanks to the inadequacy of intellect. In short, the position is mined, because it conceals a lurking dogmatism. At the time, however, Morris was unaware of this. Accordingly, he devoted himself to elaboration of the difference between the phenomenal and the real. His final period opens with this recourse. His first book, British Thought and Thinkers, is permeated by the antinomy of modern criticism. He had yet to learn that 
"The freedom of spirit can vindicate itself against the necessity of nature, only if it is possible to lift the controversy into a region in which those two are no longer left dogmatically opposed to one another, but placed in due relation through the one principle which explains the possibility of each kind of experience, or even, if it be so, of seeming experience."*

Morris had not gone "back to Kant." A real reckoning with the Prussian Hume would have taught him years earlier that the pillar of cloud by day and the pillar of fire by night are signals of the Wilderness of the Red Sea, not of the Promised Land.

The attitude adopted by Morris towards British thought, though by no means ungenerous, is definitely critical. It therefore affords a direct clue to his own standpoint. He says:-

"In general, those who most scout metaphysics are the most dogmatic in their metaphysical assumptions. Every man must have, and does have, consciously or virtually, his philosophy, and if from prejudice or indolence he will not take it from philosophers, or seek it by appropriate philosophical methods, he is sure to take it from some other source, and the chances are ten to one that he will be led astray. The empirical psychologist is rarely content to be that and nothing else, but is prone to seek in his science the answer to philosophical questions. This is what Locke intentionally did. But for this very reason, in the language of an extremely able English critic, he 'took description for explanation'-and incomplete description at that." $\dagger$

For Morris, this is typical of English thought. He is fully aware that, from Bacon to Spencer, professional thinkers see their problem through a medium which, while it lends their work a distinctive atmosphere, limits their outlook. They all descry an irrational element in

* The Critical Phrlosophy of Immanuel Kant, Edward Caird, Vol. I., p. 42 (1st ed.).

$\dagger$ British Thought and Thinkers, p. 193. 
experience, so that any possible solution would necessarily bring them into conflict with reason itself. The consequence is that, ultimately, they abandon the most profound questions of life, thus, in principle, relegating them to the tender mercies of irreflective dogmatism. The empirical and intuitional schools divided the empire between them, splitting the universe in halves. Accordingly, man was either a mere incident in the mechanical order, a beast, sorrowing because he could contemplate his dread fate; or, cut off from this order, he became the exponent of caprice, the master of a lawless will. Morris was quick to seize the former alternative and to expose its hollowness, but the latter still lay in shadow for him, it was almost unsuspected.

On the other hand, he saw clearly that the English poets, Shakespeare conspicuously, were profounder philosophers than the professed thinkers, although, thanks to his partial analysis, he failed to insist that, after all, poetry 'is a noble lie.' He approves the poetic achievement so thoroughly as to blink the plain fact that, by its very nature, art, no less than empirical psychology, must eschew ultimate analysis. Now it is doubtless one of the several paradoxes of æsthetic history that, unlike their prototypes, the Romans, the severely practical British have contrived to endow mankind with the greatest body of poetry in any language. Probably we must seek the reason in the coexistence of two nations within the realm. The contrast, implicit since Layamon, became open after the Revolution. Puritan and Cavalier, Calvinist and Jacobite, represent two types of contrasted background, each antipathetic to its yoke-fellow. The vast majority does indeed find salvation in the narrow, strenuous 
individualism of the one; no less, an influential minority, the more powerful on account of its strategic social position,finds congenial principles in Platonizing idealism. Yet, this idealism remains dogmatic at basis, so that, on the whole, two dogmatisms confront each other mutually antagonistic, but, in the deep things, mutually supporting. On this account, for example, Carlyle was hardly less open to reason than Spencer. For, as Mazzini wrote, the Scots prophet had "a constant disposition to crush the human being by comparing him with God," while the English agnostic merely pulverized him between the upper and the nether millstones of 'subject' and 'object.' Small wonder, then, that in their anguish, both cry aloud for the mysticism native to poetry.

As I have said, Morris sensed this in part, not altogether. For he omits to insist that the members of a paradox are related, because they belong equally to the same universe. He tends to solve the difficulty by ridding himself of one term. Hence, he has no eve for the third great contribution of British thought to human culture-science-where, after a manner, the age-old opposition between philosophy and poetry is overcome. At its best, it illustrates the real nature of the ultimate problem, without shirking. British philosophy does indeed betray the limitations portrayed so admirably by Morris. But, British poetry has all the limitationsof poetry. So, we must seek such rational approaches as the English mind has taken, not in either of these, but in the principles indispensable to scientific progress. It has been pointed out, with remarkable insight, that, compared with French and German, British contributions to science are inferior in methodical arrangement and in bulk. 
"But among them is a small number of works of the first order which are embodiments of scientific ideas of the very highest importance. Introduced into the great edifice of scientific research which was being planned and erected on the Continent, they mark the very corner-stones of the building."**

Nay more, the master, synthetic conceptions controlling scientific thought are of British origin. Despite the enormous advantages conferred upon individuals by the organization of the French academies and the German universities, the continent boasts no names -Pasteur excepted-that thrill us like Newton, James Watt, Adam Smith, Faraday, Darwin or Clerk Maxwell.

"Where the height of genius forbids emulation, where the towering intellect has distanced all records . . . in this sphere," of science, "which more than any other seems to bear an international and cosmopolitan character, the genius of the nation strongly asserts itself, baffling every effort to control it or to lead it into more conventional channels." $\dagger$

The fact seems to be that the continentals were straitened by extreme division of labour. They could not be themselves, a force majeure, as it were, condemned them to fragmentary activities, whether they willed or not. Free to develop personal idiosyncrasy, the English displayed profounder insight, and were natural philosophers. Nor have their neighbours over the North Sea been unaware of this.

"In the natural sciences today, a resolute attempt manifests itself to rise above the world of empirical detail to the great principles which govern everything and connect it into a single whole: the desire, that is, for a Philosophy of Nature, not forced from the outside, but arising from the subject itself. At the

*A History of European Thought in the Nineteenth Century, J. T. Merz, Vol. I., p. 276 (1st ed.).

† Ibid., p. 280. 
present time, in the field of mathematics, a similar need makes itself generally felt-a need which has always exhibited vitality in England."*

Now, this premises the unifying power of seminal conceptions whereby the opaque single facts are transformed into significant, even if subordinate, parts of the edifice of truth. The particulars and the universal are thus seen in their satisfying, because 'absolute,' relation. And in this connection, it is most noteworthy that the great seers of British science, in contrast with popularizing commentators, have sat loose to the philosophy of the schools as a rule. For this reason, I suppose, Darwin wins upon us the more we know of him, while Spencer repels. $\dagger$ There is something large and altruistic about the one, something small and petulant about the other. Quite unconscious of this aspect of the matter, and of the problem which it presents, Morris is weak, and the weakness is a symptomatic commentary upon his own viewpoint just when a fuller light was about to break.

The 'rage and sorrow' evoked by the facile, noisy metaphysics of materialism, coupled with lack of personal experience in the processes of positive science, prevented him from seeing that science never advances by simple accumulation of empirical details. Synthetic concepts must inform even the minutest datumwhereupon it ceases to be abstract and becomes concrete. A system is a system of relations or nothing. So much so, that the notion central to it, whatever be the science,

*Vorlesungen über d. complexen Zahlen $u$. ihre Functionen, Hermann Hankel, I. Th., pp. 9-10.

† Spencer's Autobiography and Duncan's Life of Spencer alike confirm this impression which, otherwise, is mitigated only by the pathos of the situation or by one's sense of the nobility of the career. 
enables us to differentiate historical epochs. Thus we have good reason to speak of the Newtonian and Darwinian epochs, because there is a Newtonian, a Darwinian philosophy. As Romanes said of Darwin:

"Natural history is not to him an affair of the herbarium or the cabinet. The collectors and the species-framers are, as it were, his diggers of clay and makers of bricks; even the skilled observers and the trained experimentalists are his mechanics. Valuable as the work of all these men is in itself, its principal value, as he has finally demonstrated, is that which it acquires in rendering possible the work of the architect. . . . In his eyes the value of facts is due to their power of guiding the mind to a further discovery of principles. And the extraordinary success which attended his work in this respect of generalization immediately brought natural science into line with the other inductive sciences, behind which, in this most important of all respects, she has so seriously fallen. For it was the Origin of Species which first clearly revealed to naturalists as a class, that it was the duty of their science to take as its motto, what is really the motto of natural science in general,

Felix qui potuit rerum cognoscere causas.

Not facts, then, or phenomena, but causes or principles, are the ultimate objects of scientific quest."**

In other words, the perennial problem of the One and the Many returns for judgment, and we should not be so obsessed by the special connection in which it may emerge as to forget that, after all, this is the ultimate quest of the pivotal discipline of philosophy-metaphysics. Whatever be the field of inquiry, the implicit difficulty concerns the nature of the synthetic principle, its relation to the particulars and the interpretation of

* Darwin, and After Darwin, Vol. I., p. 5 (1st ed.). Cf. Darwin and Hegel, D. G. Ritchie, pp. 38 f., and especially pp. 60 f., where the unfortunate tendency in interpretation of final cause, which Morris drew from his German teachers, may be gathered. 
the Whole. The moment this shines clear, philosophy ensues, and we ask - are there other principles, of the same type fundamentally, to which the working hypothesis of $a$ science must be referred; above all, can we discern one principle to which every other must be carried back? Thus awakened, man cannot but undertake the task of primary criticism. When he rides off upon exaltation of poetry at the expense of a phase of philosophy, or of mysticism at the expense of a special science, he merely drags the wheels of his chariot. In the long run, temporary reasons for begging such questions, no matter how insistent, serve only to increase the urgency.

No doubt, as it specializes, science develops peculiar, perhaps inevitable, limitations. For obvious reasons, the past century has accentuated them to such a degree that reaction begins to appear. Bacon says:

"Another error ... . is, that after the distribution of particular arts and sciences, men have abandoned universality, or philosophia prima; which cannot but cease and stop all progression. For no perfect discovery can be made upon a flat or level: neither is it possible to discover the more remote and deeper parts of any science, if you stand but upon the level of the same, and ascend not to a higher science."*

Had Morris dwelt upon this aspect of Bacon's teaching, he might have noted that the same abandonment of philosophia prima was chargeable upon another special science-theology, particularly the 'conciliation' theology in its uncritical aspects. Here too, a blunder was committed, identical in principle with that which he fixes so persistently upon British philosophy. In this respect, the vestiges of Natural Theology operated

* Advancement of Learning, Bk. I., Chap. v., sect. 5. Cf. Bk. II., Pref. Sect. 8; Chap. v., Sect. 2; Nov. Org., lib. I., 80. 
powerfully. A recoil from the subversive speculation, affected by rhetoricians of science in the first blush of optimism, led Morris to lay undue stress upon what he believed to be nothing "but atheism under a mask." $\mathrm{He}$ therefore attempted to vindicate the reasonable character, not of Religion, but of certain dogmas wherein $a$ religion had crystallized at a definite stage in its history, forgetting that these involved more or less definite philosophical presuppositions. Thus, his attitude was theosophical and mystical, just as that of contemporary science was empirical and mechanical. Accordingly, in so far as philosophy and science shared a mutual rationalism, both came under the same condemnation. The implicit error happens to be very old, and is not by any means dissipated yet. We may venture to put it paradoxically. The fundamental difference between philosophy and science resides in the more thoroughly empirical character of the former. All that science adopts as experience, philosophy has already recognized -it sends the sciences on their several missions of exploration. But, over and above, there is a portion of experience which science at once omits and presupposes; this philosophy recognizes also. It cannot confine its attention to an abstract part, for its problem concerns the concrete Whole.

This forthwith raises the question, What is experience? And, for the generation to which Morris belonged, the answer was given by Kant and his immediate successors. Be our judgment of their results what it may, this has become part of history.

From the outset, British philosophy had adopted an unscientific or, rather, fragmentary view of experience. It mistook states of sensuous consciousness for the 
original experiential data, missing the significance of the self-conscious self. Hence the pertinence of Ferrier's acid remark-penned before psychology had become a special science.

"The best way of attaining to correct opinions on most metaphysical subjects is by finding out what has been said on any given point by the psychologists, and then by saying the very opposite."*

Or, following Ferrier again, and taking a particular case, Berkeley alone had the necessary "eye for facts." Nevertheless, he too was so influenced by the national avidity for sense-knowledge, as

"to invest the Deity ... with human modes of apprehension, with such senses as belong to man-and to invest Him with these, not as a matter of contingency, but as a matter of necessity. Our only safety lies in the consideration . . . that our sensitive modes of apprehension are mere contingent elements and conditions of cognition; and that the ego or subject alone enters, of necessity, into the composition of everything which any intelligence can know." $\dagger$

Hence, Berkeley failed and came short, like his predecessors, as, indeed, every subjective idealist must. Omitting Ferrier himself, and John Grote who, for reasons that may not detain us here, fell far short of adequate recognition, it was not till the lapse of some three generations after the Critique of Pure Reason that a group of English-speaking thinkers arose, who were destined to naturalize the Kantian succession in Britain, Greater Britain and the United States. I say 'naturalize' advisedly. For, thanks to passage of time, we now see that the old labels-Neo-Kantianism,

* Institutes of Metaphysic and the Theory of Knowing and Being, p. 322 ; cf., pp. 324 f.

† Ibid., p. 398 . (3d. ed.). 
Neo-Hegelianism, and so forth-were misleading. This point had been taken repeatedly by leaders of the movement, like T. H. Green and Edward Caird, although little heed was paid. We may cite the latter, and at the moment when his school rode on the high flood of success.

"A reference to definite names is in philosophy often taken to imply a kind of discipleship which cannot be acknowledged by those who believe that the history of philosophy is a living development, and who, therefore, are adherents of a school only in the sense that they trace the last steps of that development in a particular way. The work of Kant and Hegel, like the work of earlier philosophers, can have no speculative value except for those who are able critically to reproduce it, and so to assist in the sifting process by which its permanent meaning is separated from the accidents of its first expression. And such reproduction, again, is not possible except by those who are impelled by the very teaching they have received to give it a fresh expression and a new application. Valuable as may be the history of thought, the literal importation of Kant and Hegel into another country and time would not be possible if it were desirable, or desirable if it were possible. The mere change of time and place, if there were nothing more, implies new questions and a new attitude of mind in those whom the writer addresses, which would make a bare reproduction meaningless. ... Any one who writes about philosophy must have his work judged, not by its relation to the intellectual wants of a past generation, but by its power to meet the wants of the present time-wants which arise out of the advance of science, and the new currents of influence which are transforming man's social and religious life."*

After 1878, Morris joined the ranks of philosophical teachers. He therefore came under bonds to be fully persuaded in his own mind-not about natural theology, or poetry, or science, or dogmatic theology, but about first

* Essays in Philosophical Criticism, Edited by Andrew Seth and R. B. Haldane, pp. 2-3. 
principles. Looking for aid, he could hardly fail to note that the most vital thought of the time, congenial, too, by its adaptation to the ways of English-speaking folk, and by its profound sympathy with the problems which had absorbed him hitherto, emanated from the British idealists. Poetry, as in Coleridge, Wordsworth, Browning, Tennyson, Carlyle and Emerson, was all very well; but it must needs be divested of mysticism, and its unexamined principles had still to be proven immanent in the common things of common experience. The movement, hesitating at first, gathered strength slowly; but, ere Morris came to feel the necessity for fundamental criticism, several most important works had appeared; we are aware that he studied them, and took keenest interest in their authors.* The evidence shows that he gave heed to Green, the Caird brothers, Wallace and Adamson in particular. Accordingly, these affiliations represent his final stage. We cannot conjecture what he might have done had he been spared to transcend the double-refraction process, and to produce an original

* They were as follows: The Secret of Hegel, James Hutchison Stirling (1865); The Dialogues of Plato (with the famous introductions), B. Jowett (1871); Hume's Treatise of Human Nature, edited by T. H. Green and T. H. Grose (with Green's epoch-making Introduction, 1874); The Logic of Hegel (with the admirable Prolegomena), W. Wallace (1874); Cartesianism, E. Caird (in the Encycl. Britannica, 1876); Ethical Studies, F. H. Bradley (1876); A Critical Account of the Philosophy of Kant, E. Caird (1877); Shaw Lectures On the Philosophy of Kant, R. Adamson (1879); The Social Philosophy and Religion of Comte, E. Caird (in the Contemporary Review, 1879); An Introduction to the Philosophy of Religion, J. Caird (1880); the controversy between E. Caird and Stirling over Kant's Deduction of the Categories (1880); Kant and his English Critics, J. Watson (1881); Fichte, R. Adamson (1881) -in the Blackwood's Philosophical Classics Series, which Morris was to follow in a new form; Text-book to Kant, J. H. Stirling (1881); Prolegomena to Ethics, T. H. Green (1883). 
constructive work in a special department. As it is, the Ely Lectures alone exhibit him in a rôle other than that of the commentator. And they are-lectures; moreover they pertain precisely to that aspect of experience where the New England conscience most beset him. Hence, in expression,- - the wealth of Biblical quotation witnessing,-if not in thought, the doctrinal interest prevails. No doubt, the occasion and immediate environment of the Lectures played their part. In any case, it is highly suggestive to observe that the words used by Edward Caird, who is contrasting his own more strictly philosophical outlook with the tendencies induced in his brother, John Caird, by "his life as a pastor and preacher," are not without application to Morris's Philosophy and Christianity.

"What he sought in philosophy was primarily to make faith intelligent and intelligible. ... At the same time he had a confidence, which did not lessen with time, that such modifications could not touch anything which was really essential to religious life, or to Christianity . . . a deep and, I may say, an unshakable conviction of the general truth of the Christian view of life. . . Perhaps he did not realize-I say this only to indicate a difference between us which was never completely settled in all our discussions-how great must be the transformation of the creed of Christendom, before, in the language of Goethe's well-known tale, the hut of the fisherman can be transformed into the altar of the great Temple of Humanity."*

Truly, "the work of Kant and Hegel can have no speculative value except for those who are able critically to reproduce it." And the reproduction by Morris was not that even of his British contemporaries. The inexpugnable New England conscience made all the difference.

* "Memoir of Principal Caird," in The Fundamental Ideas of Christianity, Vol. I., pp. Ixvi-vii. 
British Thought and Thinkers, then, while palpably the product of a full and refined mind, lacks the poise of wisdom. Morris knows what he opposes, he does not know himself. By inference, we gather that he is fully persuaded in his own mind, only to suspect that he is over-persuaded. He says:

"On the whole, both in religion and in science, I think we may say with obvious truth that the characteristic disposition of the English mind is to lay hold upon alleged revealed or natural laws of fact, in their immediate, practical relation to the life and interests of men, and as narrowly observable in detail with the microscopic vision of sense. With this goes a tendency to neglect that more comprehensive and penetrative mental labor which traces the rational connection of all law with its birthplace in the mind and will of an Absolute Spirit."*

He delights to contrast "a certain insular Bornirtheit" with the "remarkable exhibition of concentrated moral and physical power in the intellectual and moral Gedanken-arbeit, or travail of thought, which has been going on in German climes for the last two hundred years." $\dagger$ But, thus far, he has not reckoned "critically to reproduce it, and so to assist in the sifting process by which its permanent meaning is separated from the accidents of its first expression."

Hence, a veritable philosophy

"looks upon all causation as the operation of power-but not simply of power in name (whence termed unknowable), but of real, known, intelligible, and hence rational, spiritual, power. It, too, admits necessity; not, however, the necessity of fate, but the necessity of the Best. . . . But it does not commit the absurdity of supposing that the instrument practically creates itself and is subservient to the ends which are accomplished through it, simply by accident." $\ddagger$

* Pp. 26-7.

$\dagger$ Pp. 26, 21.

$\ddagger$ Pp. 384-5. 
Thus,

"not only man, but the whole universe, is placed in intelligible continuity, though not identity, with the Absolute Reality, or Supreme Cause."*

No doubt, all this may very well turn out true. But, reminiscent of his early Calvinism and his recent NeoFichteanism, Morris has yet to learn how one can maintain a system of immutable truth without abstracting from the characteristics of experience. A "Supreme Cause," for example, would seem to strand him between mutually exclusive alternatives, both meaningless. For, as between the deep sea of an infinite regressive series, and the devil,- an unconditioned member of this series,he can scarcely be said to have won far towards an "Absolute Spirit." Agreed-he has read the sign-post, "no road this way"; a notable, because very rare achievement. Nevertheless, to affirm of others, that they "treat as an affair of sensible demonstration an order of truths which lie back of, and indeed shine through but are not absorbed in, sensible data," $\dagger$ by no means indicates possession of the clue to the maze.

Thus we gather that, till the last decade of his life opened, he remained in unstable equilibrium. It would be going too far to adopt the curt remark of Höffding about the younger Fichte, and agree that, in Morris, too, "tendency was stronger than intellectual interest," turning him "back to the ready-made God of popular theology." $\ddagger$ For, in opposition to contemporary empiricism, he has a most definite conception of the task and scope of philosophy. Philosophy proper is the

* P. 387 .

† P. 167. The italics are mine.

$\ddagger$ History of Modern Philosophy, Vol. II., p. 267 (Eng. trans.). 
theory of life.* But life proves to be "the omnipresent demonstration, in the midst of the phenomenally actual, of the commanding reality of the ideal-i.e., of rational, spontaneously active, ever directly or indirectly creative spirit." $\dagger$ As a result, there is a "tendency"- to revert "to an appeal to personal feeling as the only force which can here carry us to the goal." $\ddagger$ On the other hand, a little later Morris asserts that philosophy "can be called the science of self-conscious reason." Hence "it is the sole business of philosophy to comprehend" the "whole world of actuality." It

"perceives that, throughout the universe of living existenceand this, subject to exact definitions, must be conceived as equivalent to the whole actual universe - the mechanical is conditioned by and logically posterior to the organic; the dead is the product of the living, the phenomenal of the noumenal."\$

Now, no matter what our attitude towards this view, we cannot but agree that it at once raises the problem of the nature of experience, with which, apparently, Morris had not yet reckoned. This perceived, he tells, us:-

"One of the happiest signs of the times is the new industry with which the study of philosophic science, both in itself and in its history, is now being cultivated. The watchword in Germany is now-after an interval of comparative philosophical exhaustion, which followed soon after Hegel's death-"back to Kant!" But this really means not only "back to Kant!" but "back to those successors of Kant who for the time completed his work!" In Great Britain during the last decade a remarkable galaxy of scholars and thinkers have come to the front, who

* Cf. British Thought and Thinkers, pp. $84 \mathrm{f}$.

$\dagger$ Ibid., p. 97.

$\ddagger$ Höffding, $l$. $c$.

$\S$ "The Philosophy of the State and of History," in Methods of Teaching History, pp. 157 f. (2d ed., G. Stanley Hall, editor). 
have broken over the insular boundaries of earlier British speculation and have given to British thought a new and healthier tone. The old "metaphysics," including that of its most recent conspicuous representative, Mr. Spencer, seems, fortunately, to be already quite obsolescent. . . . What does all this mean? At what are they aiming? . . . Their aim is in its substance not a new one, but as old as all comprehensive human thought. It is, of course, primarily to promote the knowledge that philosophy, as a special science, exists and has peculiar problems."*

The eight years which the locust had not eaten were occupied with this investigation and in this setting.

Thus, the final period may be dated from the Princeton Review article, "Philosophy and its Specific Problems." Here we find that "Philosophy now is nothing but the examination of our whole and undivided experience, with a view to ascertaining its whole nature, its range, and its content." $\dagger$ Like so many thinkers at the time, Morris is traversing the doctrine that a generalization about "the redistribution of matter and motion" includes and contains "the final explanation of all that man knows or can know." This

"Is the 'spur of denial' which has goaded the human mind in every historic instance of high philosophic achievement on to the rescue of its most sacred and substantial, $i$. e., its ideal, possessions. The plausible and destructive, though superficial doubt of the Sophists, was followed by the energetic self-assertion of intelligence in Socrates, Plato, and Aristotle. The spiritualistic negativism of Spinozał and Locke served as a counterirritant to Leibniz. The philosophical scepticism of Hume awoke Kant from his self-confessed 'dogmatic slumber,' and

*Princeton Review, Vol. IX., (new series), pp. 216 f. The italics are mine.

† P. 212.

$\ddagger$ The tendency to minimize Spinoza seems to have been persistent with Morris. It is traceable, probably, to his inherited culture which, in this case, warped his acquired knowledge of the history of philosophy. 
Kant brought forth those not less illustrious and influential 'Epigonen' who, if they did not reconstruct, certainly rehabilitated, the world of mind and man's undivided experience."*

For,

"The dogma of our necessary ignorance concerning aught but sensible phenomena is not a physical object. It is an ideal persuasion, which, if demonstratively established, results, not from the investigations of physical science, but from inquiries which belong to the science of knowledge, the science which determines the nature and scope of all knowledge." $\dagger$

Accordingly, it is necessary to be more "experimental" $\ddagger$ than the empiricists. Kant was the pioneer of this movement. His

"Critique of Pure Reason is simply a re-examination of the traditional British theory of sensible consciousness, with the result of showing that all consciousness is not merely sensible, but also intelligible. . . . But Kant went only half way in his exploration of conscious experience. Under the influence of early prejudice he was led to treat intelligence only as a logical or formal aspect of sense, which latter was held to be the dominant factor in consciousness and alone the determining factor of real knowledge. His successors demonstrated, not by farfetched, roundabout ways of indirect 'proof' or of merely plausible but fanciful hypothesis, but by a more complete and scientific examination of the facts of the case itself, that sense is rather only an aspect of intelligence; that intelligence, further, is not merely subjective, a purely formal mechanism of the intellect, but is also objective, and stretches out spiritual arms to embrace, not the dark phantom of the 'unknowable' or of the inaccessible, because non-sensible, Ding-an-sich, but an intelligible, rational, self-illumining, and self-explaining world of living, present, and effective reality."§

* Pp. 210-11.

$\dagger$ Pp. 211.

$\ddagger$ Throughout the article, Morris employs "experimental" and "experiment" for experiential and experience.

§ P. 222. 
The article concludes with an outline of a system of philosophy: "Science of Knowledge; Science of Being; Nature, Society, Art, Religion." Morris's books, from the study of the Critique of Pure Reason, deal with the first, as seen through Kant historically; with Society as presented by Hegel; and with Religion, in the Ely Lectures, from his own standpoint.

The prospectus of the Series, German Philosophical Classics for English Readers and Students, undoubtedly written by Morris, contains a remark that serves to throw considerable light upon his method of approach to Kant.

"The aim in each case will be to furnish a clear and attractive statement ... of the original author's argument... and especially to show, as occasion may require, in what way German thought contains the natural complement, and much-needed corrective, of British speculation."*

On the other hand, we find Adamson, for example, seeking the reasons for the return to Kant

"Not only within the limited sphere of philosophy proper, but in the wider sphere of science and the ordinary consciousness. . . . The rapid development of the physical sciences has not only brought their results into apparent conflict with the ordinary principles of thought and conduct, but has roused attention to the ultimate notions involved in scientific procedure as such." $\dagger$

Upon the whole, an emphasis of this general character marks the works of the British commentators on Kant. Not so Morris. As his reviewer in Mind has it, his expositions "have been aimed at the froward generation that still looks for some philosophical fruit from 'English Psychology."' $\ddagger$ But even this is hardly a complete

* The italics are mine.

† On the Philosophy of Kant, p. 7.

$\ddagger$ Vol. VII (Old Series), p. 604 . 
account of the matter. His attitude is the issue of a long intellectual history. He comprehends his own problem through Kant, and calls upon the great critic to determine the disposition of the New England conscience as it now found itself in a newer America.

We have had abundant reason to see that the New England conscience contributed the positive element to Morris's mental and spiritual being. But in his case, as often happens, the positive implied a negative. The 'Eternal Yea' of Puritan moralism was countered by the 'Eternal Nay' which natural science, intoxicated with success, had quickly generated. The immediate extravagances were such as to vex even the patient, sympathetic soul of Lotze who, with pardonable irritation, wrote:

"Here, too, men pass from timidity to presumptuous boldness. Having once tasted the delight of impartial and wholly unfettered investigation, they rush into a sham and puerile kind of heroism that glories in having renounced that which no one has ever any right to renounce; and reposing boundless confidence in assumptions which are by no means incontestable, estimate the truth of their new philosophic views in direct proportion to the degree of offensive hostility which these exhibit towards everythingexcept science-that is held sacred by the living soul of man."*

Time has softened these antagonisms greatly, at least among the masters who know, so much so, that they lack reality for us. Nevertheless, we must remember that in Morris's day, they occupied the foreground of the picture. Moreover, many believed that a certain type of pure philosophy, English empiricism particularly, was in unholy league with this deification of science which, as they also held, involved an implicit dogmatism.

${ }^{*}$ Microcosmus, Vol. I., p. 8 (Eng. trans.). 
The American vogue of Spencer furnished sufficient proof. For, do not "the present professors of natural science," despite

"their noisy glorification of experience ... with laudable modesty question in many individual cases whether they have yet discovered the true law which governs some group of processes under investigation; but they have no doubt in the abstract as to the presence of laws which connect all parts of the world's course in such a way that, if once complete knowledge had been attained, infallible inferences might be made from one to the other."*

By what right is philosophy, whose business it is to criticise the "inadequate, disconnected and frequently inconsistent ideas of Physical Science," similarly dogmatic? Morris felt that this dogmatism was no less partial than that in which he had been reared, and he set himself to combat it. He was awakening to the fact that the 'closed' universe of modern idealism, as of modern naturalism, not content with absorbing man's physical life, had laid hold upon his very personality. Hence, a fresh interpretation had become necessary, one not only new in America, but also little germane to the 'philosophy of science' as it went then. Accordingly, the naturalization of Kant is a naturalization precisely in proportion as Morris was touched by these controversies. So he proceeds to develop his positive teaching through the negative medium of criticism upon another position.

The book on Kant's Critique of Pure Reason is precisely "A Critical Exposition," as the title-page asserts. Without delay or circumlocution, Morris strikes his key-note decisively in the first paragraph of the "Introduction."

* Metaphysic, H. Lotze, pp. 3-4 (Eng. trans.). 
"The works that have marked epochs, of one kind or another, in the history of philosophy, are very different in character. Some of them are constructive, and lead to positive conclusions; others are destructive, and end mainly in negations; others, still, are "critical," marking periods of transition in the history of philosophic intelligence, from negative or skeptical to more positive and affirmative convictions. Examples of the first class are found in the writings of Plato, Aristotle, Leibniz, Hegel and others. Hume's 'Treatise on Human Nature' illustrates conspicuously the second class; while of the third, Kant's 'Critique of Pure Reason' furnishes the most noteworthy instance."*

Viewing philosophy as the science of Being, to which the science of Knowledge furnishes "the key," Morris maintains a continuous polemic upon the assumption that "all knowledge is sensible knowledge." For,

"If all human knowledge were specifically and exclusively sensible ... agnosticism would be the last word of philosophy. But this is the same as to say that philosophy would not, in any positive sense, exist. For philosophy is the science of Being; but agnosticism consists in nothing but a persuasion that no such science is possible." $\dagger$

In so far as survivals of this attitude find favour with Kant, the critical side of the exposition predominates; in so far as Kant freed himself from these survivals, in principle, the expository side prevails.

The following passages serve to indicate the line of approach very clearly. In them, as in the entire volume, we sense the beat of the coercive New England conscience.

"Modern philosophy before Kant's time, had, as a whole, been effectually stunted in its growth. This in consequence of two circumstances: first, that as a general rule, the so-called

*P. 1.

†P. 10. 
founders of modern philosophy made it a principle of their procedure wholly to 'break off from the past' . . . and secondly, that modern philosophy took its rise at a time when the mathematical and physical sciences, which are specifically concerned only with the facts or conditioning forms and relations of sensible existence, were being, or beginning to be, cultivated with unusual zeal and success. . . . All this is signally illustrated in the general complexion and results of the philosophy of Descartes and Spinoza, notwithstanding the garb of dogmatic idealism with which their doctrine is more or less completely invested. . . . Leibniz, the one man who, thoroughly conversant with the mathematical and physical science of his time, and also with ancient as well as with modern philosophy, towered above all others of the two centuries between which his life was divided, in the matter of philosophic insight, continued, while correcting Descartes' and Spinoza's error of conception, to employ for the Absolute the term which they had used. He called it substance, but then declared, 'Substance is Action'. ... And we may say that, corresponding to this defect in expression, the grand defect of Leibniz's whole doctrine arises from the presence in it of a mechanistic element, not reduced into harmony with the main spiritualistic tendency. . . Even more signally, though in a very different fashion, is our thesis respecting the prevailing character of philosophy before Kant's time illustrated in the history of British inquiry. . . . The original direction of Kant's mind was thus not exclusively, or even mainly, toward 'metaphysical,' or technically philosophical, problems.... The growing influence of his predilection for physical inquiries, and of his increased and absorbing study of British writers, such as Newton, Shaftesbury, Hutcheson and Hume, 'led him to declare' that 'the genuine method of metaphysics is substantially identical with that which Newton introduced into physical science.' . . . Metaphysics must find its place 'on the lowly ground of experience [sic] and common sense.' Its principal work is to analyze the 'confused' contents of consciousness, or our 'ideas.' ... Here Kant touches philosophical low-water. ... In 1763 , he already gives marked evidence of the disturbance in his thought caused by Hume's negative conclusions respecting the nature of scientific causation or law. . . . 'Anything might 
be the cause of anything.' In this way scientific law was eviscerated of all rational significance. . . . The main starting-point of the 'Critique of Pure Reason' is to be found in the results of British sensational empiricism, as formulated by Hume. The work has then a double object or result, a proximate or immediate and a remote or indirect one. Of these, again, the former is two-fold, consisting $(a)$ in establishing the at least formal dependence of sensible knowledge, and especially of pure mathematical and physical science, on intellectual or spiritual, as well as mechanico-sensible, conditions, and $(b)$ in enforcing the truth that the conceptions and method of physical science, as such, are irrelevant for the demonstration or disproof of truths which lie deeper than, or beyond, the immediate sphere of purely sensible phenomena. Through the first or immediate result, especially the second part of it, the remote or indirect one is reached, which is, to 'secure a place for faith'. . . . And this is what Kant proceeds to do in his second and third Critiques. ... The more important result must, and undoubtedly will, be a return to those successors of Kant in whom his thought is completed; or, still better, a return to philosophy and its peculiar method, irrespective of all the names, whether ancient or modern, which stand for its highest achievements."*

Thanks to his intellectual environment, then, Kant identified the world of physical science with the world of 'theoretical' knowledge; hence our conception of 'substance' is relative, being applicable to phenomena only. Categories cannot do more than define and distinguish, because subject and object are separate from one another. Nevertheless, space and time, "energies of the mind," constitute a living bond between the thinker and his object, the product of an active, spiritual function. They imply the presence and potency of 'understanding,' but merely to a limited degree. Causality, for example, must be restricted to simple time-relation. This mechanico-sensible interpretation exhausts its theoretical

*Pp. 29-42. 
significance. On the other hand, the fact that this would reduce the category to the level of a product of composition, and render it secondary, is, as Kant says, "a challenge to reflection." The origin of "this unity is none other than the unity of pure self-consciousness."* In other words,

"The notion of a causal relation as existing between successive phenomena, or between successive aspects of the same phenomenon, is the result, not of our perception, but of our conception. Hume is right in saying that we never "perceive" any necessary, or any other real, connection between phenomena or 'objects.' ... Indeed, the notion of nature itself is a priori; it is our notion, our creation; and the categories, which determine the form of the universal laws of nature, are but the constituent elements of this mind-created notion itself." $\dagger$

Necessarily, then, Kant implies that the range of sensible knowledge is "less extensive than the field of absolute reality." $\ddagger$ Phenomena are not noumena. Nevertheless, the latter possess no objective significance, and therefore metaphysics is a delusion. Thus, we are left with a flagrant contradiction or, rather, with a vacuous verbalism.

"A pure subject or a pure object is not only unknown, but inconceivable. It is pure nonsense. It is no wonder, therefore, that if the realm of "things-in-themselves" or of "noumena" (or both) is made up of pure subjects and pure objects, they are "unknowable," and that, as Kant declares, 'it is impossible for us to conceive how, even if we cannot deny that, they exist." "§

Therefore,

"Had Kant carried his work far enough to examine and recognize that all self-consciousness is in itself, instead of stopping

* P. 108.

$\dagger$ Pp. 117-18.

† P. 181.

\& P. 199. 
short with the mere recognition of the 'formal' or 'logical' necessity of self-consciousness to sensible consciousness, his practical conception of noumena would, on the one hand, have been less incomplete and mechanical, and, on the other, instead of being merely practical, it would have been also theoretical; 'faith' would have been transformed into, or recognized as, knowledge."**

Kant's "arbitrary major premise," that there can be no knowledge except what is "presented to consciousness in and through sense affections," $\dagger$ vitiated his entire analysis, and prevented him from seeing the ultimate implications of his own procedure. In sum, consequently, his criticism "absolutely fails to touch the real foundations or the real superstructure of philosophy." $\ddagger$

Despite all this, however, the practical issue of the demonstration-that metaphysics has nothing to say pro or con respecting the existence of its ideal objectsby no means results in a barren negative. For, "pure reason is not only receptively cognitive, it is also legislative." So "arises for man the absolute practical necessity of regarding himself as possessing a nature, and belonging to a world, which are more than sensible."' In short, Kant was struggling to become the intellectual redeemer of his times, working "toward the region of larger light and more catholic comprehension."

Confined by the prejudices of an unhistorical age, he "was undoubtedly right, when, in the last paragraph of his book, rejecting as ineffectual the 'dogmatic method' of the 'celebrated Wolff' and the 'sceptical method of David Hume,' and practically treating these two as the

\footnotetext{
* P. 203.

† P. 217.

$\ddagger$ P. 219.

\& P. 267.

|| Pp. 270-1.
} 
only methods having historic existence, he confidently recommended the 'critical way,' and declared":

"The critical way alone is still open. . . . The reader . . . may now judge whether . . . that, which many centuries could not accomplish may not be attained before the lapse of the present century, namely, the complete satisfaction of human reason respecting those problems which have at all times aroused its curiosity, though hitherto in vain."

And, Morris adds, marking his final position, "Fiftyone years after these words were written Hegel died. . . . The "courage of knowledge" was absolute. Kant's prophecy seemed to have been fulfilled."*

Familiarity with the Kantian succession, and special study of the Critique of Pure Reason, thus led Morris to the conclusion that

"Individual or unipersonal self-consciousness reveals itself as not merely numerically one and self-identical, but as the one which pervades the many, the individual which is one with the universal, and which makes or has the many and the universal as an organic part of consciousness itself. . . . This larger self is divine; it is universal, living, effective reason, it is absolute Spirit. The individual's sufficiency 'to think anything of himself' is, thus, 'of God.' It comes from his participation in a light which can be, in its completeness, no less all-embracing and all-creative than divine reason." $\dagger$

In short, the ideal is the living truth of real things. He was enabled to restore theism, and to find in God the prius of everything possible to a human experience. A valid theory of knowledge cannot but lead to the theistic conception of the universe. Morris found that the Kantian criticism, when its internal logic was carried through to the bitter end, justified the coercive postul-

* P. 272.

$\dagger$ Pp. 130-1. Cf. the remarkable passage, pp. 124-30. 
ates which had disciplined him in youth. But, in justifying them, it transformed them, thus preserving the principle of freedom always championed by 'Independency.' Old things had become new. The consequence was that he began to achieve a victory over his own doubts. He would have agreed with Mr. Bradley:

"I will end with something not very different, something perhaps more certainly the essential message of Hegel. Outside of spirit there is not, and there cannot be, any reality, and, the more that anything is spiritual, so much the more is it veritably real."*

But he found it quite natural, if not inevitable, to conceive of God as self-conscious, and to identify God with the Absolute. That is to say, the theological interest swayed him, somewhat to the exclusion of the purely speculative. This appears very plainly in the single constructive work he was to leave.

As we have noted already, it was an unfortunate coincidence that the sole book in which Morris gave free play to his own ideas should have been a series of lectures, delivered upon a Foundation instituted for apologetic purposes. The occasion compelled him to consult edification, and philosophy has no more to do with edification than chemistry. But, the Deed of Gift of the Ely Foundation in Union Theological Seminary, New York, provides that

"The course of lectures given on this foundation is to comprise any topics that serve to establish the proposition that Christianity is a religion from God, or that it is the perfect and final form of religion for man.

"Among the subjects discussed may be,-

* Appearance and Reality, p. 552 (1st edition). 
"The Nature and Need of a Revelation;

"The Character and Influence of Christ and His Apostles;

"The Authenticity and Credibility of the Scriptures, Miracles, and Prophecy;

"The Diffusion and Benefits of Christianity; and

"The Philosophy of Religion in its Relation to the Christian System."

Now, these are very general terms and, like all general terms, their interpretation cannot but be relative to the age in which they were formulated. Hence, it is important to notice that the Deed was dated at New York, May 8th, 1865. At this time the forces of Pietism and Rationalism were still locked in struggle. As has been admirably said,

"The breach between the liberal and conservative tendencies of religious thought in this country came at a time when the philosophical reconstruction was already well under way in Europe. The debate continued until long after the biblicalcritical movement was in progress. The controversy was conducted upon both sides in practically total ignorance of these facts. . . . The men in either camp proceeded from assumptions which are now impossible to the men of both. It was not till after the Civil War that American students of theology began in numbers to study in Germany."**

Accordingly, while Morris chose the last subject mentioned in the Deed, it is worthy of record that he nowhere betrays any sense of fretfulness under the limitations of the occasion. Indeed, he buckles to his task con amore. Throughout the course, he makes practically no reference to the results of higher criticism, $\dagger$ but proceeds to read the main doctrines of Protestant dogmatics in terms of what may be loosely called

* An Outline of the History of Christian Thought Since Kant, E. C. Moore, pp. 18-19.

† Cf. pp. 3 f. 
Hegelianism of the extreme Right wing. This serves to explain the plan of the work. After an introductory lecture devoted to discussion of the relations between "Religion and Intelligence," the "Philosophic Theory of Knowledge," and the "Absolute Object of Intelligence, or the Philosophic Theory of Reality," are considered. Then, following somewhat the beaten track of dogmatic theology, the body of the book* is occupied with the "Biblical Theory of Knowledge; Biblical Ontology - the Absolute, the World, and Man." The concluding lecture reviews the "Comparative Philosophic Content of Christianity." We are thus forewarned that we must not anticipate a philosophy of religion, but merely an account of the manner and degree in which the 'substance' of Christianity can be aligned with systematic reflection. It is essential to bear this purpose in mind, because the author is dominated by it thoroughly - the more that it consorted with his profoundest spiritual experiences and needs. The atmosphere is that of a pietistic, but not dogmatic, orthodoxy, while the perspective is that of absolute idealism, mediated theistically. Morris stands forth as a "Christian spiritualist," where 'spirituality' implies a definite philosophical creed, and this almost in the sense of a gospel.

He conceived the problem of Philosophy of Religion clearly, but elaborated it somewhat narrowly.

"The essence of religion is contained, for intelligence, in certain presuppositions respecting the absolute nature and relations of things, with the truth or falsehood of which religion, as an object of intelligence, stands or falls. It presupposes that absolute being is Spiritual, and that Divine Spirit is the source

* $164 \mathrm{pp}$. of a total of $281 \mathrm{pp}$. 
and king and goal of all dependent being. . . . It implies that man is, in his true nature and intention, a spirit, and that he is able, required, and above all, privileged, to enter into living relations to the Divine Spirit,-in which relations more especially, religion directly consists or has its immediate life.* . . Our purpose and method will require us, accordingly, first succinctly to indicate the general nature and results of the philosophic theory of knowledge and of the absolute or final object of knowledge; and then to seek to state . . . the conceptions respecting the same topics, which are presupposed or proclaimed by Christianity; with a view to showing that the Christian conceptions are not repugnant to the conceptions of philosophy, that the former are, rather, the fulfilment and enrichment of the latter." $\dagger$

Starting with these norms, it is not wonderful that the treatment is tinctured strongly by a tendency to edification-unfortunately. $\ddagger$ As a result, Love becomes the ultimate ontological principle; and, because Love is perfect, it affords an objective basis for the spiritual life, for morality and religion. 'God is Love.' Therefore,

"We find Christianity declaring, and philosophy assenting to and confirming the declaration, that all things live and move and have their being in God; but not that they constitute God."§

Thus, in contrast to Browning, of whom he reminds one occasionally, Morris does not sever Love from knowledge, and place them in antagonism. He realized that the 'heart' must learn to speak the language of the 'head,' if the permanent principles which underlie and

* P. 16.

$\dagger$ P. 19.

$\ddagger$ Cf. $e . g .$, pp. $57,91,96,98$ f., 184 f., 258 f., 267 f., 303 f. " "It is not the business of philosophy to praise the universe or to exalt the satisfactions of goodness." The Value and Destiny of the Individual, B. Bosanquet, p. 327.

$\S$ P. 203. 
impart strength to faith were to be brought into the light of distinct consciousness and delivered from the accidents with which, at first, they are necessarily identified.* Or, as Browning himself put it,

"I needs must blend the quality of man

With quality of God, and so assist

Mere human sight to understand my Life." $\dagger$

A distinct tendency to what some have called 'intellectualism' therefore runs parallel to the appeal to Love. $\neq$ And in so far as Morris effects a reconciliation between the two, he succeeds by an unconscious application of the New England conscience. The moralistic element differentiates him from his British colleagues, Green the most conspicuous exception. This had been, not merely his heritage, but the teaching of his German masters, Trendelenburg particularly.

"The genus of motion is not change of place, but fulfilment of purpose. . . . This process we have already termed 'organic.' . . . Here Nature shows explicitly that her being is grounded in spirit, that her life is the life (Plotinus used to say, the 'sleeping life') of spirit. She thus points everywhere backwards and upwards to the Absolute Spirit as the ever-present and omnipresent ground and creative source of her own existence. But also, and in particular, through the series of her forms, which advance through a rising scale in ideal content, worth, and significance, she points to the full and explicit development of finite selfconsciousness, as in man, as the proximate end to which all her varied activity is (again) but 'instrumental.' . . . And so it is that, while man is called on to work out his own salvation, he has also the assured knowledge that God works in him both to will and to do of His good pleasure. The great glory of man, accord-

* Cf. The Social Philosophy and Religion of Comte, E. Caird, pp. 186 f. (1st ed.).

$\dagger$ Poetical Works, Vol. XVI., p. 83.

$\ddagger$ Cf., e. g., pp. 92, 95, 208, 231, 252, 259, 304. 
ing to the Christian conception of him, is that he is a co-labourer with God."*

Thus,

"The contrast between human and divine intelligence is then this: the former has for its first or immediate object the physical universe, as a language, the true reading of which brings it to the present knowledge of the divine Word, as the truth, or absolute causal reality of the universe; the latter, on the contrary, has for its first object, the absolute object, the Word, and only-if we may thus express it-in the second instance, or through the Word, by and through whom alone the physical worlds subsist, has it these latter for its object." $\dagger$

\section{Therefore,}

"The true and perfect doing, in which consists the true and perfect living, is a conscious, purposeful, and willing activity, which (on man's part) accomplishes the will of God, the absolute law of being, and so only effectually realizes its own nature. . . . The will, therefore, which identified itself with the will of God,the will which, primarily, or in the first instance, wills nought but God, and then wills all else from the point of view of God or of the absolute and divine will,--possesses that absolute substance of freedom, wherein consists the perfected reality of the spirit. This is freedom through knowledge, love, and practical realization of 'the truth." "†

Stated in Christian terms, then,-and Morris attempts no more here,- religion

"Does not simply consist in being informed of and then formally accepting a 'scheme' of rescue from the damning consequences of sin. It is not merely salvation from something; it is also the salvation of something, viz., of the true man. It is the creative-redemptive realization of the perfect man in living union with the Absolute, with God. And if the ethics which it involves is not 'human ethics,' then no such ethics ever existed

* Pp. 83-4, 207.

† Pp. 157-8.

$\ddagger$ Pp. 136, 242-3. 
or can, without an essential change in the nature of man, ever exist."*

Thanks in greater part, no doubt, to the occasion and to the apologetic object of the lectures, the argument as a whole is strained in the interests of faith. Thus, the book represents a transition stage in philosophy of religion. In one sense, it is too theological, in another, it is not theological enough. For this reason, I take it, the fundamental problem-the relation between personality (as attributed to God) and the Absolute-is scarcely faced. Consequently, although the personality of God is strongly affirmed, it remains, all things considered, a bildlicher Ausdruck, a pictorial declaration of the religious consciousness, an 'appearance' rather than the Reality. The truth seems to be that Morris concerned himself too exclusively with the ideal aspect of religion, and omitted to stress the factors contributed by Nature and Society. He had forgotten Goethe's maxim:

"Willst du ins Unendliche schreiten, Geh nur im Endlichen nach aller Seiten."

He reposed too little confidence in the 'finite' and, therefore, did not penetrate it sufficiently. The desire to take the kingdom of heaven by storm remained strong. In short, he had not contrived to divest himself completely of Deistic influences and, to this extent, failed to come to close quarters with the methods of Theism. Thus, while there is no sort of vacillation, inconsistencies appear. Of course, the drift is towards speculative idealism, but with lapses into an ethical theism which, occasionally, come perilously near in-

*P. 251. 
tuitionalism, or mysticism, or an emotional theism, as the case may be. Thus the book offers, as it were, an eirenicon between the phases of his own personal experience, rather than a systematic philosophy of religion. As with T. H. Green, the reaction against empiricism forms the point of departure and, also like Green, Morris portends the kind of idealism which found an expression almost classic in Lux Mundi. He is not attempting to furnish "the natural corrective" to his youthful "dogmatic system." Hence, he inclines to anticipate "the results of a more advanced stage than" he "has yet attained," and goes too far in the direction of "the form under which feeling discounts the future gains of thought."*

Whatever we may think now of the Hegelian attitude towards religion, it was a great gain when, a generation ago, Morris found himself able to adopt it, and to declare, almost with passion, that, in the last analysis, the object of religion is identical with the object of philosophy.

"The philosophic and the religious conception run hand in hand." $\dagger$

And if, sometimes, he forgets that, while religion mayeven must-demand immediate personal relation to God, philosophy must invariably try to exhibit the nature of the Absolute mediately, he nevertheless clears the ground for discussions that had been impossible under the Puritan dispensation. English and American individualism was prone to consider God as outside of, or 'over against,' men. Accordingly, the lower and less adequate forms of anthropomorphism came to possess undue, if not fatal, prominence.

* Cf. The Evolution of Religion, E. Caird, Vol. II., pp. $291 \mathrm{f}$.

$\dagger$ P. 280. 
"Absolute Being is here the object of their consciousness; and, as such, is for them pre-eminently the 'other,' a 'beyond,' nearer or further off, more or less friendly or frightful or alarming."**

Further, no matter with what disguises of refinement, this standpoint was maintained in essentials by the exponents of 'Design,' 'First Cause,' and the like, whose doctrines furnished Morris staple training at first.

"Meanwhile the conceptions of matter and of nature had been passing beyond the phases at which the argument for final causes took them. The relationship of a creator to the creatures as that of an architect or manager to his works was no longer deemed adequate, nor did it seem the highest praise that he had made the best of somewhat recalcitrant materials. The great mechanician is only a mode, and an insufficient mode, of conceiving God's supremacy; and even if it be specially suitable to the genius of a utilitarian age, it cannot rank as more than an analogy of the divine mode of action. . . . Religion had little to gain by these demonstrations; at least any religion which had real vitality and was not a form of words parasitically seeking to gain support from these growths." $\dagger$

Thus, it was a great gain, I repeat, that a man of profound piety should have seen this and, seeing it, have accepted the issue when and where he did. Morris had come to realize that philosophy cannot furnish, much less justify, any object out of all relation to experience; his mysticism is the measure merely of his religious vitality here. And, even granted that the implications altogether outrun the theological philosophy of the Ely Lectures, they were raised notwithstanding.

His problem was to outline a reasonable faith, not as yet to formulate a systematic philosophy of religion.

* History of Philosophy, Hegel, Vol. I., p. 62 (Eng. trans.); Werke, Vol. XIII., p. 77.

$\dagger$ Lectures and Essays on Natural Theology and Ethics, William Wallace, pp. 9-10. 
Accordingly, he witnesses that religion involves emotions peculiar to itself, and also that, eventually, these emotions produce coercive intellectual persuasions. Such persuasions, in turn, so far as they outstrip knowledge,as they do,-belong to the realm of faith. Nevertheless, they find expression in propositions of metaphysical significance. Consequently, Morris adopts a definite attitude which, whatever its infusion of emotionalism, may be defended as essential to religion. Although his statements are not always crisp, he is thoroughly aware that religion demands the existence of its object, and this not simply as an object, but as the object of worship, because the embodiment of the ideal.

"All things are yours, and ye are Christ's, and Christ is God's."

In other words, the assurance characteristic of religion consists more in a quality of experience than in specific beliefs. Unless the one perfect reality existed, life would be an illusion; but, seeing that this reality exists, life shares in its completeness already. Thus, the religious man should never so far forget himself as to condemn the world; for, properly viewed, this is the place where salvation has its seat now. Grasp this, and you grasp everything. Man is man, but vaster.

Again, if this conviction have a solid basis in faith, it follows that the object of worship must possess a character unassailable by the defects of time and sense. So, keeping close to the Hegelian view, Morris holds that, in the Christ, we have a definite realization of the unity between God and man. And this implies that the Christ manifested the whole fullness of the Godhead bodily. The finite person disappears in the adequate 
revelation of the infinite individual. Thanks to his mysticism, Morris hardly exhibits the terms of this paradox. I doubt whether he was aware of them. $\mathrm{He}$ remains too much of the religionist, has become too little of the metaphysician. Notwithstanding, he is right to a certain extent. As concerns theory, religion cannot well escape mysticism. Demanding an existent infinite, it seems bound to meet the demand by affirming that the present life can find its truth only in a higher existence, which the bare fact of this world already postulates. Nay, an emotional ontologism becomes the court of last resort-a strange contradiction.

Thus, while Morris went all the way with an adequate view of religion, his traditions" would not permit him to go more than a mile with an adequate metaphysic. Those points, at least, deserve note. Moralism rears its head still, as if current conventions in conduct were the sole pathway to heaven. Individualism still has its say, as if the ideal could not be realized except on the plan native to New England. The appeal to coercive emotion is still magistral, as if chosen objects or values, themselves characteristically temporal, could furnish all-sufficient predicates for the universal. In short, forgetting the paradox central to religion, in his anxiety to affirm Christian truth, Morris tends to take the kingdom of heaven by merit, little recking that, in the nature of the case, human 'perfection' is as filthy rags. Being too righteous, he is not religious enough. For, he would fain reduce his faith to a form of knowledge, if not to a species of activity.

Accordingly, in the stage at which he had now arrived, he could never compass a consistent philosophy of religion. It scarcely occurred to him that religious 
experience always 'steps down' the Absolute. Man, being man, clothes upon God with certain temporal qualities-a Fichtean 'striving' for example-which have no application to complete individuality from a metaphysical point of view. Thus, although the recent doctrine of the finitude of God is unsuspected, and luckily,-for it raises greater difficulties than it removes, - the simple identification of God with the Absolute fails to go to the root of the matter, because the relevant phenomena of religion are not subjected to thorough criticism. Nay more, Morris speaks as if a single type of religious experience were a valid representation of the Absolute. Indeed, the transcendent aspect of his theism exerts such strong bias that the main conclusion reposes upon a hypothetical antecedent. Accordingly, vindication of religious conviction postpones inquiry into the fundamental organization of experience as a whole. Not that the problems are evaded; they are there, and are liberated so far from Calvinistic presuppositions. But complete independence in metaphysical inquiry still lags, chiefly because the reaction against empiricism is so sharp that recourse to a theological position ensues too easily. Warmth of faith tends to induce satisfaction with a supernal Ultimate, $a$ Being that suffices $a$ religious consciousness, but not one by any means capable of immediate identification with the Absolute.

It is plain, then, that, thanks to his labour with philosophy of religion, Morris was progressing, and progressing rapidly. But the end was not yet, nor was it to be reached, death interposing. Intellectual courage abounded and, with it, keen speculative interest; opportunity to fare farther and more freely from inbred, limiting ideas, was never granted. 
Finally, the last book, Hegel's Philosophy of the State and of History, merits notice as an admirable, if all too brief, exposition of these masterpieces. The short Introduction does indeed defend Hegel's attitude towards ethics, but so succinctly that Morris leaves no place for his own views. The thorough mastery of Hegel's text and meaning makes one regret the more-especially when the date of publication is recalled-that he did not omit the Philosophy of History, in order to give fuller treatment to the Philosophie des Rechts, then misunderstood sadly in the English countries. It is true that, in the essay, "The Philosophy of the State and of History,"* contributed to the volume, Methods of Teaching History, he approached the subject suo more, but again most briefly. He whets one's appetite.

"History is not simply (multifarious) events. It is the logic of events. Historic intelligence is not merely information respecting events. It is the comprehension of their logic." $\dagger$

The logic of history is a great theme, but the essay goes no further than a very general statement of some principles of idealism.

"Philosophy demonstrates that the essential and all-determining nature of intelligence is to be self-conscious reason. And it also demonstrates that the true self-consciousness is something that transcends the individual, being realized only through the 'objective' consciousness and progressive knowledge of the whole universe of dependent existence, and in organic dependence on an universal and absolute self-consciousness. . . . And if the philosophy that one have, or that one find current, be unfortunately one-sided, abstract, and inhospitable toward certain sides of that whole world of actuality, which it is the sole business of philosophy to comprehend, yet one must accept

* $18 \mathrm{pp}$.

† P. 150. 
it, and apply it as far as it will go, and so make the best of it. . . . I hasten to add that, when this is done, the relative truth, and, within its peculiar bounds, the important truth of the mechanical philosophy in its application to the moral world, which includes the world of history, will be fully recognized. No one can shut his eyes to the mechanical aspect which belongs to all events whatsoever that occur within the bounds and under the forms of space and time, including, therefore, the events of history. But the eye of really concrete, catholic, and all-embracing philosophic science, sees that the mechanical aspect of events is only an aspect. ... True philosophy perceives that, throughout the universe of living existence-and this, subject to exact definitions, must be conceived as equivalent to the whole actual universe - the mechanical is conditioned by and logically posterior to the organic; the dead is the product of the living, the phenomenal of the noumenal."*

Hence, although Droysen is right when he asserts that "the subject of history is the universal Ego of humanity," or that history is the moral self-consciousness of man in the act of knowing itself, it is nevertheless equally true that "the concrete form in which this subject lies before the historian and student of history is that of social organizations or of states." $\dagger$ The essay does not proceed to indicate the fundamental relation between these two 'aspects,' much less to hint at the difficulties to be surmounted. At the first blush, the mere statement of the developmental or synthetic point of view is so much more suggestive than the individualism which it ousts, that the incidental problems, inseparable from adequate zu Ende denken, remain in concealment. Shortly after Morris died, The Chronicle, then the bi-weekly organ "published by the Students of the University of Michigan," printed a series of admirable

* Pp. 154, 157-8.

† P. 160. 
papers, entitled "The Ideal and the Real: Professor Morris's Published Writings."* At the outset, we find this: "The present writer, it should be said, is fully aware that the published writings do not contain all of their author's best and most fully elaborated philosophical opinions." $\dagger$ Nothing could be more obvious. The whole available evidence tends to show that Morris's influence as a man and teacher greatly surpassed anything that could be gathered from his writings. In fact, when death overtook him, he was just beginning to find his feet philosophically, so to speak. Idealism as a gospel of deliverance from a faith that puzzled sorely, because it was at once outworn and yet rightly oriented, had taken complete possession of him. But he had not yet possessed it, so as to apply its principles to some of the most obscure and difficult problems of experience. The new light so suffused everything with its golden glow that the shadows were dissipated too speedily and readily-they could not obtrude. And it must be remembered, in this connection, that the two great leaders of British idealism, Morris's contemporaries, who exerted most potent sway over their pupils, have been charged similarly, despite the fact that the more favourable circumstances of their lives enabled them to devote themselves exclusively and continuously to philosophy.

Thomas Hill Green who, like Morris, died prematurely, aged forty-six, deflected English thought, and even British politics, through his pupils. $\ddagger \mathrm{He}$, too, " preached

*Vol. XX., pp. 278 f., 290 f., 303 f., 315 f. They were unsigned, but I have been able to ascertain that the author was Dr. B. F. Burt.

$\dagger$ P. 278.

$\ddagger$ As I recollect, Edward Caird told me, in 1906, that some fifty of Green's pupils were in the House of Commons and, I think, five in the Cabinet. 
Hegel with the accent of a Puritan."* But, probably because he also was possessed by a gospel, he did not experience the full stress of difficulties such as were to be raised in the next generation by his most brilliant pupil, Mr. F. H. Bradley. $\dagger$ Thanks to the Puritan tradition, and to the sharp reaction against empiricism, $\ddagger$ he won, too easily, perhaps, to the ultimacy of personality, with its identification of the Absolute and God; he passed too lightly over the "self-contradiction in principle" inherent in morality, viewed as a final category; $\S$ and he accepted the conviction of immortality on grounds that seemed to some theological more than philosophical.

In the same way, one of the most devoted and able pupils of Edward Caird has recorded:

"Some will always regret that he did not set himself rather more directly to the exposition of the views to which he himself had been led, instead of to the interpretation and criticism of others. He might then have dealt more specifically with some of the difficulties that are felt as still remaining in the view to which he leads us-such as those with respect to the reality of time, the nature of evil, the relation between the finite and the infinite, and similar problems. . . . But it should be remembered that it was his main business to introduce what was almost a new way of thinking to English readers; and even his enemies allow that in this at least he was successful. Those who complain of the thinness of its results should bear in mind what a young and tender plant our British idealism still is." $\|$

* Memoir of John Nichol, Wm. Knight, p. 150.

$\dagger$ Cf. His Appearance and Reality.

$\ddagger$ The conviction that this rebound had gone too far was expressed, as early as 1889 , by another of Green's best pupils, Prof. Samuel Alexander, in his Moral Order and Progress. Curiously enough, this was the first Green Memorial Prize Dissertation at Oxford. A later one, Prof.

A. E. Taylor's Problem of Conduct, raises similar questions.

$\S$ Cf. Appearance vs. Reality, ch. xxv.

\| Prof. J. S. Mackenzie, in Mind, Vol. XVIII. (N.S.), p. 536. 
Here, again, Nichol, in whom the sceptical spirit was ever active, struck home, and once said to me, "Caird's greatest limitation is that he has a gospel."* Further, Morris was fated to introduce an entirely new way of thinking to American readers, and American idealism has remained a plant even more tender than British. Everyone has heard the famous witticism of William James, about "defining the Absolute for a dollar"! Thus, Morris never passed beyond the missionary stage, and the thinker-his message no less-had the defects of qualities, if withal, the qualities of defects. By way of summary, let us try to sense these aspects of his intellectual situation.

Morris enjoyed one immense advantage. From childhood, he was nourished on questions which inevitably developed an interest in metaphysics. At first, of course, he accepted statements of profound significance without suspicion of their scope or possibilities. Even so, they amplified his outlook, because they embodied

"The influence which draws men's thoughts away from their personal interests, making them intensely aware of other existences, to which it binds them by strong ties sometimes of admiration, sometimes of awe, sometimes of duty, sometimes of love." $\dagger$

It thus happened that, disturbed by conviction of sin, the acute form of human frailty, Morris sought the true Reality wherein all is made whole. In this way, then, he acquired an enthusiasm for ideas, in the shape of ideals, even if his intensity compelled a certain narrowness. But reading, German experience, and the conflict with scepticism, corrected his early rigorism, without shifting the centre of his absorption. The

*Cf. my article "Edward Caird," Harvard Theological Review, Vol. II., p. 135.

† Natural Religion, p. 236 (London, 1882). 
'spiritual idealism' of the final period softened and enlarged the Calvinism of youth. In addition, keen emotional sensibilities, finding outlet in love of poetry and delight in music, tended to render him a prophet more than a cold, critical theorist. Accordingly, he took his place among that "band of veritable apostlesmen who were burningly convinced of the essential truth of" the doctrines of idealism, "and filled with pity or contempt for all who could continue to think along the traditional English lines," who carried Hegelianism "over into the English-speaking world." And, thanks precisely to this element of prophetic fervour, "the success of their endeavors was most rapid."* Indeed, as a consequence of the bias given by early associations and training, Morris was ever something of a personalist, as if an idea peculiar to himself, or germane to his immediate aspirations, were the key to all mysteries.

Thus, once more, he had his advantage at a price. $\mathrm{He}$ hardly saw that the dangerous foe of idealism is, not materialism, but dualism. For, disciplined to account Christianity a thing apart, it was more than difficult for him to replace this tradition with a conception of experience dependent upon a view of unity that overthrew every artificial barrier between the sacred and the secular. No doubt, he came to realize that a denial of the possibility of knowledge of the infinite struck at the foundations alike of thought and morals. Nevertheless, he scarcely arrived at the point where this unity became fatal to the last form of exclusivenessthe separate self. Odd reminiscences of the 'relation between faith and works,' survivals of Puritan modes,

* Cf. Introduction to the Science of Ethics, Theodore De Laguna, pp. 344-5. 
maintained a separation between self and the Ultimate. Insistent that man's universe must be spiritual, he was less mindful that, to this end, it must also be intelligible throughout. The eighteenth century died hard in him, so that, on occasions, he spoke as if the Absolute were the antecedent of the universe rather than its explanation. In short, while Puritanism had been liberated from its cruder constraints, it contrived to persist under the guise of a certain abstractness. The antithesis between man as phenomenal and man as noumenal, so plain in that rigorist thinker, Kant, appealed to the inherited moralism in Morris, and with such force that it could not be swept away utterly. This was the debt that he paid to his time and opportunity. Hence, till the end, a Protestant attitude, more theological than philosophical, tempted him, not to evade, but to miss, some problems. Unquestionably, he found no little support here from the letter of Hegel, particularly as he found it in the Philosophy of Religion. In any case, he was prevented from noting that, in his attempt to retain theological statements, Hegel was not Hegelian enough. More than likely, this limitation must be charged, not to early training alone, but also to German teaching, and to the rebound from empiricism. At all events, when he harks back to a spiritual Absolute, Morris finds himself able to rest content with the familiar phraseology of faith. The new meaning, which he read joyously into the old terms, concealed part of the problem, just because former implications were so definite and coercive.

Finally, Morris was a pure humanist in all essential respects. Moreover, he was a humanist perforce; and in this element of constraint his qualities and defects 
alike root. Whatever he may have thought about the contribution of modern science to the well-being and advancement of humanity, his vital interest lay elsewhere. His mind found food for reflection in religion, art, morality, social phenomena, and the history of philosophy. He desired principles, and proposed to obtain them by criticism of the ideal nature of man. Respecting 'outer' things, his constant purpose was to penetrate their spiritual ground and order. And necessarily. As a lad, he had received baptism into that internal spirit, which no external forms could embody adequately,- the permanent touchstone of Puritanism in the English-speaking world. Accordingly, he regarded the individual 'soul' as something set apart, and his later struggle was to surmount this dualism, in order to detect spirit everywhere. His inability to appreciate Spinoza throws light upon the difficulties that beset him as he took his new way. Thanks to Puritan sentiment, he might almost have exclaimed, with Rousseau, "I abhor Spinoza!" And yet, the evangelical pietism of youth did incline him towards a species of Platonizing intelligence. For, 'conviction of sin' and 'assurance of grace' played their parts in a dialectic movement which, in turn, demanded reference to a principle of higher unity. Further, the 'private judgment,' so typical of Congregational 'independency,' enabled him at last to reach this unity rationally. But he arrived at his philosophical solution thanks to a conviction which partook strongly in the nature of faith. Like the New Englander,-bred to his Bible, led by his authoritative ministry, and supported by his grave folk,- -he found 'eventual rest atop the mount' through a consecrated education, and was therefore 
able to conserve the habitude of the old doctrines in the free movement of the new thought.

His cultural experience had been such that the idealistic positions of the final period were no vague aspirations, but convictions that welled up from his central being. It came natural to him to insist that crass objects are not empirically 'given,' nay, are themselves reasonable only upon the basis of an idealistic reference. Indeed, if sensible things be independent existences, all science - a rational systematization-becomes then and thereby impossible. Hume had rendered any other view an anachronism long since. Thus, Morris was able to escape a dualistic theology only to the extent to which he could free it from the philosophical blunders that were common to it with the temper of the entire Aufklärung. Inevitably, this brought him into violent conflict with the popular metaphysic adopted at first, worse luck, by the votaries of modern science. Very naturally, then, he reverted to a humanistic standpoint and, as naturally, the core of theological teaching could be retained. The obvious dependence of man still was 'upon God,' not upon the blind forces of a 'foreign' Nature. As a result, the formula of the creeds, so far from repelling, afforded genial terms for the statement of the conclusions of modern idealism. Here at least, he found himself liberated beforehand from the spatial, temporal and mechanical modes which he contemned in empiricism. Nay, he could express his mature convictions in phrases with which he had been familiar time out of mind.

But, although he never knew it, he had a price to pay. Reason and faith agreed in the way quickly,-too quickly for a full survey of the great gulf fixed "between a prin- 
ciple and its development into a system."* So his expression of the new truth in the old language lent his philosophy a more theological cast than it actually bore. In any case, however, he was 'coming home' here; and he would undoubtedly have asserted that, so long as the 'spiritual idealism' was grasped, the manner of its statement mattered little. In this he agreed with the British leaders of the school. And, unversed in technical theology, he interpreted theological terms as no more than a system of doctrines which were systematic because intimating the presence and operation of a single principle common to all. Let words be what they may, the vital thing for philosophy is the immanent principle; for religion, the life, the 'new heart.' The former is conditioned by rigorous thinking, the latter uncritical. Hence a danger, which Morris did not escape altogether. General propositions, especially if their form be consecrated by ancient usage, interpose too readily between real problems and necessary criticism. Like other exponents of idealism in his generation, he therefore dreav a cross-fire. As we have seen, the orthodox suspected him-was he not making philosophy mistress in the house of religion? While empiricists could affirm, as one of them-his colleague-remarked to me but yesterday, "Morris never became a scientific man." For them, his method of approach to their questions was unintelligible or inapplicable, if not a piece of mere prejudice.

At the last, he could probably have countered the former with success. He would have replied that they had foregone freedom in order to conserve truth, and

* Cf. Essays in Philosophical Criticism, edited by Seth and Haldane, p. 6 . 
that, consequently, their truth was a house built on the sand. And he would have proceeded to point out that, till faith saw sound reason for the truth that was in it, there could be no sure foundation. It is not so clear that he could have countered the scientific consciousness. He hardly knew it with the requisite intimacy. For, as we have also seen, his own faith implied problems that had not been dragged into the light of reason. He was not thorough enough with the sensible world, and therefore did not realize the scope of the new metaphysical difficulties raised by the transformation of science after 1847. Accordingly, his universal being in a measure a particular, he unconsciously divorced it from the objects of science, only to renew its universality as an object of faith. I cannot but think that the teaching of Trendelenburg exerted mischievous influence here. And Morris, coming to the real Hegel late, had not sufficient contact with him to overcome Aristotelian-and Puritan-dualism completely. His early bias had been exceptionally coercive, and it led him, afterwards, to seize the whole before the parts. To some extent, then, when he studied Hegel, he took the 'labour of the notion' for granted. Had he not laboured already in blood and tears! He thus missed that close grapple with the sensuous conditions of human infirmity, the indispensable prelude to persuasive insight. Sensitized as he had been, Hegel so overbore him, especially by the extreme theological form of the Philosophy of Religion, that he hurried through the "door of escape from the ordinary and fruitless alternation of dogmatism with scepticism" which "Hegel opens."

"The living process by which a mere germ of knowledge becomes transformed into a fully articulated organism ... 
stands aloof from reality or aspires to be a construction in vacuo in Hegel's system less than in any other."*

Untimely dead, Morris enjoyed no opportunity to return full circle upon this fundamental consideration.

Nothwithstanding, these very limitations rendered his intellectual history more thoroughly representative. It is abundantly plain that nothing was so powerful in shaping it as his slow progress towards emancipation from the theological ideas of New England. Nay, their influence continued to determine his approach to philosophical problems and his rating of their respective importance till the end. So much so, that one cannot do better than transfer to his case what has been so admirably said of another scholar, similarly nurtured, and similarly cut down ere he had reaped the ripe fruit of his labours. The biographers of Robertson Smith record

"That he refused to sacrifice either his faith or his reason; and this contradiction will disconcert only those who do not perceive that it is the ultimate contradiction in human life. All intellectual experience, when analyzed, presents the same antinomy. It is only in intellects of high distinction, such as Smith's, that it is likely to attract attention. . . . It is only in a character of transparent honesty such as his that it is so clearly and ingenuously apparent." $\dagger$

The truth is that Morris, like Smith, spoke to his generation out of a travail which he shared with it. $\ddagger$

* Cf. Hegel and Hegelianism, R. Mackintosh, pp. 227, 1.

$\dagger$ The Life of William Robertson Smith, John Sutherland Black and George Chrystal, p. 572 ; cf. p. 571.

$\ddagger$ As the matter concerns others no less than myself, I take the liberty to adduce, by way of proof, that Smith's deprivation of his chair, in 1881, by the General Assembly of the Free Church of Scotland, under circumstances which meant that "the accused was too dangerous a man to be allowed a fair trial, and the only exit from the difficulty was 
Otherworldliness and devotion to ideal aims he had, as of right, from the forebears. Earnestness, gravity and seriousness betokened the man who lived ever as under the eye of the Great Task Master. The ethical temper of mind that set him towards the vocation of the preacher at the first, made him a good deal of a preacher till the last. But, youthful dogmatism, growing conscious of itself, fell to pieces. Like many in his place and period, he was compelled to fare far from the old roof-tree. Profounder than most, and with an experience and opportunity in scholarship almost unique then in the United States, the quiet independence and calm serenity of the last years were possessions hard won. Forced to transform his mental, spiritual and social world, he achieved a reasonable foothold in a personalized realm, where he could rebuild his temple better-but it was always a rebuilding of the temple that he sought. Amid the stress of doubt and the pangs of change, he came to see that the God of New England was a 'mortal God.' But he found no rest unto his soul on the level of mortality. In the sweat of his brow, he must needs attempt to think through to the point where personal conviction could be persuaded to disclose its kinship with universal and necessary truth. Thanks in large measure to his character, he had his reward-in Pisgah-Sights.

\section{"Roughness and smoothness, Shine and defilement, Grace and uncouthness; One reconcilement. . . .}

to use force," that is, " a power in reserve above the ordinary constitution and law" (cf. Black and Chrystal, op. cit., pp. 412, 435), was a main factor in closing the career of the Scottish ministry to not a few of my contemporaries-so much did Smith, like Morris, represent the bitter struggle of an entire generation. It may be said, for American readers, that the adjective "Free" had nothing to do with theology, but everything with politics! 
So shall I fear thee,
Mightiness yonder! . . .
So shall I love thee,
Down in the dark,-lest
Glowworm I prove thee,
Star that now sparklest!"

The man of him being thus ampler than his books, saw of the travail-he had souls to his hire. Chastened thinker, pure spirit, circumspect scholar, sound education flowed from contact with him. His personality passed to his pupils by a secret process of transfusion and, winning upon them so as to become a vital agency, shortened the time of their tribulation. The whole man stood out forthright in the spiritual guide.

A very ingenious and studious promoter of real knowledge - the epithet is Locke's-would deem Morris a representative of "The Genteel Tradition in American Philosophy."* I disagree with this thinking gentleman - the epithet is Locke's once more-misled by a clever half-truth. On the contrary, Morris was the incarnation of a temper not yet naturalized in America, one that must be acquired ere we can stand forth stout witnesses for the things of the mind. Noblesse oblige blazoned on his unsullied escutcheon. When, thanks to him and such as he, we realize this elemental virtue, we may pass to that higher individualism, the privilege of the thinking gentleman, but possible only when the 'revolutionary' loses himself, to become the servant of an "ultimate or total nature" set towards a "predetermined goal." $\dagger$ Then, and not till then, "a prodigious world” $\ddagger$ will be brought to potent birth.

*Winds of Doctrine: Studies in Contemporary Opinion, George Santayana, pp. 186 f.; cf. American Thought from Puritanism to Pragmatism, Woodbridge Riley, p. 238.

† Ibid., p. 208.

† Ibid., p. 213. 


\section{CHAPTER IX}

\section{The Man and the Teacher}

When I turn, in conclusion, to attempt a portrait of the man "in his habit as he lived," I must depend almost entirely upon those who knew him well. Alas, that the ranks of his file should be so thin now!

When we consider significant men whose personal relations with others form the larger part of their activity, we agree forthwith that "the most pious memories of the dead are not so much of what they did as of what they were." This applies to Morris with peculiar force. For, he was one "the mere thought of whom gave encouragement in moments of perplexity, of failure, and disappointment." There is abundant testimony to the overwhelming sorrow caused by his death, the phrase, "a very, very great calamity," recurring again and again.* Similar unanimity exists to the effect that he left "a profound impression" alike upon associates and pupils. Accordingly, it is not enough to record that he was "one of the chief philosophical teachers of America," $\dagger$ or that "he had gained a most enviable name and influence among philosophical students and writers and teachers." $\ddagger$ Evidently, he possessed distinctive personality - the endowment that counts more than aught else and, in philosophy, controls. Moreover, the key to it must be found in his conviction that "it

* Cf. The Chronicle, Vol. XX., pp. 241 f., 261 f., 278 f. The Michigan Argonaut, Vol. VII., pp. 159 f., 168 f.

$\dagger$ The Ethics of Hegel, J. Macbride Sterrett, p. 30.

$\ddagger$ Mind (Old Series), Vol. XIV., pp. 471-2. 
is possible to carry back the world of experience to conditions that are spiritual."* The persuasiveness of the scholar derived its power from the ethical warmth, apostolic in quality, of the man. It was not for nothing that he was born in New England.

"What mastery his that worked a gentle rule By knowledge nobly lived!"

Thus his colleague, the late Professor Williston S. Hough, senses the real man better, thanks, no doubt, to close acquaintance.

"At times he spoke almost as one inspired with the melodious rythm of a poet and the illumination of rare philosophic insight. Yet the chief source of his power was unquestionably his own character. He will live in our thought as a remarkable exemplification of sweetness and light. His loss to Philosophy in this country is great and twofold: First, as a teacher who would have inspired a genuine interest in Philosophy in every student who came under him, and who would have educated many special and useful scholars in this field; and, Second, as a writer who doubtless had his greatest work still before him." $†$

Hence it was that, when he died,

"The great loss to the University and to the world of philosophic thinkers was for the time being overshadowed by the sense of personal bereavement felt by every one who had in the slightest degree known him, whom to know was to greatly love." $\ddagger$

"His soul was like a star that dwelt apart."

"In his character there was a rare combination of childlike simplicity and almost womanly sensibility with manly strength and decision."

"He was the very ideal of a kindly, scholarly gentleman, and the men were very few who, if incapable of deriving benefit from

* Edward Caird, in Mind (Old Series), Vol. VIII., p. 560.

† Quoted in Sterrett, l. c., p. 31 .

$\ddagger$ MS. of the Memorial of the Class of 1861, Dartmouth College, by Major Edward Dana Redington; read by him at the Class Reunion, Hanover, N. H., June, 1891. 
him as a scholar, could not profit from his example as a true man."

"A nobler and purer character it has not been my lot to know."

"His life has been a gracious gift to me."

"I prized him preëminently because all the influences and instruction that came from him arose at the heart of his personality."

"A sweet, lovable, kindly man, whose pure and noble enthusiasm for the best, machinery and routine and the requisitions of commonplace men could not corrode."

Such were the judgments of representative colleagues and pupils. Invariably, they revert to the man, ranking him altogether beyond the pages that brought him to a larger public.

"No student could go out from his instruction without increased respect for the noble simplicity of his intellectual character, without clearer notions of what is demanded from every honest man in the way of integrity and thoroughness in his intellectual convictions."**

"While we have gained in countless ways from the fullness and breadth of the knowledge of Professor Morris, we have gained infinitely more from the man." $\dagger$

Written under the smart of recent loss, it was inevitable that these affectionate tributes should be coloured by emotion. It is well, therefore, that we have from Morris's pen a deliberate account-“a new version, almost wholly rewritten"- - of the purpose of a university and of the ideal whereby a teacher should be animated. $\ddagger$ He elaborates his own attitude here, and lets slip the secret of the persuasiveness exerted by him over others, young and mature.

"The supreme end of all education is humane culture-the

* The late Professor Edward L. Walter in The Michigan Argonaut, Vol. VII., p. 168.

† Students in the Memorial of the Philosophical Society, Ibid., p. 168.

$\ddagger$ University of Michigan Philosophical Papers. First Series, No. 1. University Education. 
perfected and rounded development, in each of its subjects, of essential manhood,- and the like is supremely true of that higher and highest formal education, which it is the recognized function of Universities to provide for and direct. . . . The true University, which is, by hypothesis, something other and more than a high school, college, or technical school, has in the past had no proper existence on American soil; this is the truth which is now coming to be currently recognized and admitted. Along with this has come the consciousness or conviction that the times are ripe for something higher and better than the best that our educational institutions have in the past been able to offer; that the nation needs it; that the higher practical exigencies of our American civilization demand it; and that promising students in sufficient, and, indeed, rapidly growing numbers, are ready to seek and receive it. . . .

"The philosophical faculty alone has no special aim, and represents the organism of the University . . . the idea of the freest and most unrestricted pursuit and promulgation of any and all truth for its own sake alone. . . . Between this University ideal of human education and the life, work and organization of our American institutions for higher education it is a mild statement to say that there has been in the past a decided lack of correspondence. . . . The College faculty has not been a "philosophical faculty." . . . The College student is treated as being under discipline; and the College instructor is a disciplinarian. To the former daily tasks are set, of which it is the function of the latter to exact the performance. Neither the one nor the other is free; the student is not, for obvious reasons; and the freedom of the teacher is restricted, for the double reason that his work must, always and necessarily, be in a very considerable measure mechanical and that, in proportion as it is such, more of it can be and is required of him." . . .

Further, "The healthy tendency of the American mind toward the definite and the (supposed) 'concrete' (in opposition to the supposed 'barren abstractions of philosophy'), and the practical exigencies of our growing national life, have been the united occasion of the far more rapid development among us of special, than of general knowledge. In philosophy-which is . . . the comprehension, by intelligence, of its own nature and of its 
universal relations, with the accompanying power to give to nature her universal interpretation and to define for human life and activity their supreme ideals, whether in society, in politics, in the world-life of humanity, in art, or in religion-one may say, without excessive exaggeration, that scarcely a beginning has been made. . . . The indispensableness of philosophic culture, and all that it implies, as an element in University education, does not really need to be so much urged, as explained. ... The American mind has already given evidence of qualities that, in my judgment, peculiarly endow it for the creative development, as well as the responsive reception, of philosophic truth. . . . Abundant reason why this should be so is foundapart from anything that may be peculiar in the present stage of our national development-in the fact that the American nation is a child of ideas. Religious and political ideas, and ideals, cradled our nation in its infancy, and have been the spring and strength of all its growing life, . . . - the service of truth, goodness and beauty; and truth, goodness and beauty are to man the supreme norm of his conscious and voluntary activity; it is the highest function of philosophy to comprehend and interpret" them. . . " The unity of all truth is the fundamental idea of philosophy. The conception of the University is a specifically philosophical one. All sciences have their place in the University because they really bear out this conception, for which reason also the University is their only true and perfect home. And it is through the active, virile comprehension and exhibition of all sciences in this their relation to the unity of all truth that not only true mastery of them is demonstrated, but that they acquire their true educational value. . . . The complete scientific identity of any, the least fact is not established by mere cognizance of the fact, but by the comprehension of its relations. Tota in minimis existit natura. . . .

"The upshot of my argument is that, in a University, every student of a special science of nature should become conscious of the universal science of nature. . . . In like manner, every student of particular historic events should be trained to comprehend the universal logic of events. . . . And the results of such union, in the scientific and educating work of the University, of the one and the many, or the universal and the particular, 
will be - what? First, and negatively, the avoidance of a certain most grievous sham, or false pretense, which consists in sending forth from the highest sanctuary of human education, with the title "Doctor," or "Teacher," of half-educated persons . . . the narrow one-sidedness of whose training reveals itself in that illiberalism which consists in the riding of hobbies. . . . Let the hobbies be reserved for the later domestic and private use of those who have first learned to ride in the saddle of universal, living science. . . . Secondly, and positively, the result, as I predict, will be the realization of the more comprehensive aim of the University, which is the development in its membersalong with symmetrical and catholic culture-of intellectual and moral self-mastery. . . .

"But can this substantial, ethical result be anticipated, under conditions such as those that have been hereinbefore described? Can it be expected without more specifically ethical and religious study and training? . . . I do indeed hold, not, certainly, as a merely personal opinion, but as one of the highest truths of science, that the intrinsic condition and, rightly understood, the extrinsic completion, of all true and perfect science is ethical and religious. By ethical knowledge I understand the broadest and completest and deepest human self-knowledge, and by religious knowledge the comprehension of that saying, in which all religion and philosophy are summarily expressed, 'The Spirit is Truth.' In the former I conceive the individual as knowing himself, not alone in his personal peculiarities or in his individual differences from all other men, but also, and much more, in his organic unity with all existence-with nature, with humanity, and, in proportion to his perfection, with God. In the latter I conceive him as becoming aware of his supreme connection ('religio') with God, the absolute and universal Spirit, as the eternal ground of his own thought. . . . And so, in the name and in the form of philosophic science I would have special ethical and religious knowledge cultivated in the University for every reason, for the sake of the ideal completion and the educating power of all other sciences, for their own sake, and for the sake of their immediate unity with the highest aim of all human education. And so will the University become in fact a 'work-shop of the Spirit of God.'” 
This is self-portraiture. Morris gave himself to these ends, little understood then, and, mightily restrained by the New England balance of instincts and conceptions, of sentiments and ratiocination, he preached them with a selflessness which lent them, not weight simply, but rather, solid reality. As we have seen, the effect was immediate and profound. But-how to convey it today? I am fortunate in the material before me, and am able to furnish an admirable medium, first in Mrs. Harold B. Wilson, * and Dr. Elmer E. Brown† who after the lapse of twenty-five years, speak for the benches; second, in Professor John Dewey who, just after the death of his chief, and again, at an interval of nearly twenty-seven years, speaks as one master may of another.

Writing in June, 1914, Mrs. Wilson says:

"Mrs. Morris has asked me to send you my impressions of Dr. Morris as teacher, from a student's point of view. It is a difficult thing to do clearly or to advantage, because, I suppose, there never was a teacher who so completely set aside his personality in dealing with students, and laid the whole emphasis upon the subject. His manner was always cool, undemonstrative, and absolutely impersonal, so that even in a University where one heard a good deal of crude and opinionated talk about 'co-eds,' the scholarly atmosphere of the lectureroom was never disturbed by any self-consciousness on the part of the women. We were there simply to hear and to understand the truth as far as we were able; and even in the small gatherings that sometimes assembled in his library for special discussions, there was

* Alice A. Graves, a signatory of the Philosophical Society Memorial, as above.

† Formerly United States Commissioner of Education, now Chancellor of New York University. 
never any visible change of attitude toward us. This was part of that unusual serenity and 'deliberate escape from the trouble at the heart of things' that was so characteristic of him. We always found him tolerant, respectful of our most inane ideas and questions, and absolutely unexcitable. The happy effect of this bearing was, that while acquiring a respect for the attainment of truth, we also acquired a pleasing respect for ourselves-a very helpful part of our mental development. If this attitude of modesty on Dr. Morris's part had been a pose, it would have fallen through at once; for, the student keeps enough of the irreverent boy in him to call down the poseur. He cannot be impressed by any sort of make-believe. The genuineness of this modesty was shown in Dr. Morris's attitude toward himself. He showed no disposition to exploit himself, as he might easily have done, for he had acquired a great influence among the students, one that did not end with his class-room. The certain test of the fundamental nature of the effect of his teaching on his pupils, was the difference it made in their work all through the University. It might not have been easy to say just when and how, in the course of his lectures on 'Real Logic,' for instance, the conduct of life was definitely pointed out; but I do know that listening to them led even the most indifferent student to confess that he found it less easy to use his cuffs for a reference library at examination time-so great is the value of contact only with great thoughts about life; it may lead to better thoughts about living.

"Many teachers get wonderful results through a strong appeal to the individual, with a quick insight into the needs of each. Dr. Morris never made any 
appeal to this innocent vanity, and no one could be less concerned than he to 'advertise' himself in any wayeven by the most refined and indirect methods. One did not feel that this was because he belittled himself or his office, but rather because of a certain austere dignity of character, as well as a lack of self-consciousness.

"As nearly as I could judge, before the time of Dr. Morris and his able assistant, Dr. Dewey, the Department of Philosophy occupied a vague and dusty corner, set apart for those isolated metaphysical discussions that seem out of relation to everything. But it gradually began to dawn upon us as we listened to his lectures that what we called philosophy was really an explanation of life itself in all its relations and import. It was a recognition of the 'spiritual yearning' that comes even to the least thoughtful that underlay all of Dr. Morris's teaching. His lectures were not simply to tell us what Kant and Hegel taught, and what were the missing links in Berkeley and Hume, but to give us sane conceptions of thinking and acting. Study of philosophy was no longer to be viewed as a somewhat jocular intellectual game-shooting at an imaginary target without a bull'seye.

"I do not think that Dr. Morris cared to be merely a teacher of philosophical systems, but that, along with this, he hoped to begin the education of the higher understanding, so that, if we ever found ourselves entering the Kingdom of Heaven, we would have acquired at least an 'attitude of knowledge' toward that holy of holies. It might seem difficult to understand how his influence as a teacher should have been so largely ethical, since I never knew him to talk to us directly on the subject of conduct. But his personality, 
though quiet, was large, and he was a man of such exquisite refinement in voice, manner and thought, that one unconsciously fell into the habit of adjusting one's self to it, and of trying to meet it on its own high level. It was easier to hear and heed the 'Thus saith the Lord,' which is for many of us a vexatiously constraining admonition.

"It would be, of course, impossible for me to say anything in regard to his place in the development of philosophical thought. But, in a general way, I think the impression he gave his students was that the intellectual world was a place whose accepted traditions he did not wish to minimize. He grasped the past with one hand, and gave a generous welcome to the future with the other. He liked those changes in philosophical thought which took place by a process of development and inclusion. The old things did not make him angry, and the new things did not unsettle his mind. So he was well fitted for just the office of forming a link between the outgrown and the advancing systems of thought. What radicalism he had was not of a destructive sort. This would have been repulsive to him. He disliked rashness and violence in thought as a sort of spiritual bad manners. To destroy everything in the past, and then complain that there was nothing left but fragments, was not his method; but rather that the process, necessarily uncertain, known as 'advanced thinking,' should include a recognition of whatever truth the past had achieved.

"Even after twenty-five years, it is not possible to speak of Dr. Morris, and all his teaching did for me, without being deeply moved. The intimate, heartstirring appeal that he made, in his quiet, self-effacing way, to all classes of students, was shown at the time 
of his death. No one would have been more surprised than he at the impressive, solemnizing outburst; for he was a beloved element in University life, even to those who had never studied with him; and, for those who were his disciples, it was a period of great sorrow.

"He was not a handsome man in the ordinary sense of the term; yet often, during lecture, I have thought his face the most beautiful I have ever seen-as though a light were shining through some delicate, half-transparent mask. I never knew him to have any personal intimacies with students, though no one could be more ready at any time, opportune or not, to let his own work fall, and give all help in his power. His reticence never meant unfriendliness.

"Those who could judge of his work widely and without prejudice felt that they could never regret enough that he passed on to the Land of Silence just as he was beginning to come into his own, after so many years of patient effort."

Chancellor Brown, writing under date February, 1916, records:

"When I went to the University of Michigan, after some experience in teaching, and older by some years than the average freshman, it was with a well-defined intellectual hunger in several directions. One of these was in the direction of æsthetic appreciation. Another, much more vague, was a desire to understand how philosophy deals with the problems of life. I had known nothing of Professor Morris, but was quickly attracted by his courses in the history of philosophy and in æsthetics. As I remember it now, I made my way into his classes with my first semester in college, and took as much work with him as circumstances and regulations permitted. 
"The fineness and elevation of his personal character appealed to me strongly from the start,-the quiet manner, the deliberate and temperate expression, the unmistakable devotion to his subject, even enthusiasm for it, which never flamed out in any violence of expression, but was rather a deep and pervasive glow. I was not at first aware of this warmth. I thought rather of a philosophical detachment and even indifference. But it was not long before I felt the personal conviction of the teacher and his intense loyalty to the doctrines which he set forth.

"It was Professor Morris who gave me my first introduction to the philosophy of Hegel. I had known of Hegel, but hardly more than as a name in the history of human thought. It was not until later that I came to know of the controversies which had raged about the Hegelian doctrine, and of the historic rise and decline of Hegelianism in the thought of the nineteenth century. Professor Morris referred to Hegel's teaching as coming like a fresh wind from the mountains into the philosophical discussions of his age. I believe the doctrine, which was already anathema in a large part of the philosophical world, was to Professor Morris fresh and vital and inspiring, as it had been to many others before the time of which I am speaking. It was not until after I had left college that I read with care the fine summary of Hegel's logic which Professor Morris published in the Griggs' philosophical series. I grieved then that his death in the middle of my college course had prevented me from taking the course in this subject which he offered in the University under the title of Real Logic, following his course in Formal Logic. However far I may have wandered into the speculations of a 
more recent philosophy, I can see that my thinking ever since my college days has been influenced by that majestic system of thought which we glimpsed in Professor Morris's teaching.

"The news of his death shocked and saddened the whole University. The great body of students, who had never come in personal contact with him, knew that one of the great teachers of the institution was gone. And those of us who were studying under his direction felt that we had suffered a personal and irreparable loss."

Writing, in the spring of 1889, Professor Dewey says:*

"It was a life great, not in outward circumstance, but in spirit, and in the quality of its achievement. . . . We cannot cease to regret that the entire unconsciousness of Professor Morris that his own experiences could be of interest to others should have deprived us of any more adequate record of his intellectual development, especially in the growth of his philosophic thought. In the opening of his lectures upon British Thought and Thinkers $\dagger$ there is an allusion to himself, which is worth quoting, both because of its rarity and because it reveals how early his mind sought the philosophic channel.

"'I can remember,' he says, 'how as a mere boy, more than once, in an evening reverie, an experience somewhat in this vein came to me. All my boyish ideas of things seemed, as pure creations of my own fancy, to melt away, and there remained, as the whole sum and substance of the universe, only the empty and inexplicable necessity of being, plus a dull, confused and indescribable sensation as of a chaos of shapeless elements. Then came the return to the world such as it had actually shaped itself in my imagination - the earth, with its green fields and

* The Palladium; An Annual Edited by College Fraternities at the University of Michigan, Vol. XXXI., pp. $110 \mathrm{f}$.

† Pp. 7-8. 
forest-covered mountains, the world-inhabited heavens, the changing seasons, man and his past history and unrevealed earthly destiny, not to mention the myriad little and familiar things which would necessarily crowd the foreground of such a picture in a boy's mind. The view which a moment before had demonstrated so signally its capacity of dissolving again became a slowly changing panorama of a world. It was into such a conception of a world that I, following unwillingly a bent common to the universal mind of man, was more or less blindly seeking to introduce order and permanence. What must be? Why must anything be? Why must all things be? I need not say that the immediate result of my reflections was tolerably negative." "

"We cannot but wish as we read this that we had more autobiographical fragments to draw upon.

"The instruction Professor Morris received in college does not appear to have appealed to him particularly. Indeed, it seems rather to have impelled him, with a dislike which never left him, from what is often miscalled metaphysics, the partly verbal, partly arbitrary treatment of various recondite notions. At one period, he was a disciple of the English Empirical School, of the Mills, and of Bain and Spencer. He went so far as to consider himself a materialist. In later years, it was something more than a logical conviction of the purely theoretical shortcoming of these forms of philosophy that made him so strong, though so fair and appreciative, an opponent of them. It was also, if we may make use of some remarks of his upon one occasion when materialism was under discussion, the conviction, which personal experience had brought home to him, of their ethical deficiencies, and of their failure to support and inspire life. . . . He never surrendered the belief that genuine personal philosophic conviction must be based upon a knowledge of philosophy in its historic development. 
This belief was the basis of his opinion that what American thought needed above all else as a condition of getting out of its somewhat provincial state, was an adequate acquaintance with the great thought of the past. While he held a definite philosophical position of his own, and held it firmly, his instruction was based upon the idea that the main thing after all is to get the individual out of his restricted ways of thinking and in contact with the stream of reflective thought that has been flowing on well nigh twenty-five hundred years. For a time his own philosophic conviction was probably an Aristotelianism modified and developed by the results of modern science. ... Although Trendelenburg had incorporated within his own teaching the substantial achievements of that great philosophical movement which began with Kant and closed with Hegel, . . . he had taken a hostile attitude to these positions as stated by Hegel, and to the method by which they were taught. While Professor Morris was never simply an adherent of Trendelenburg, he probably followed him also in this respect. At least, he used sometimes in later years to point out pages in his copy of Hegel which were marked 'nonsense,' etc., remarks made while he was a student in Germany. It was thus not any discipleship which finally led Mr. Morris to find in Hegel (in his own words) 'the most profound and comprehensive of modern thinkers.' He found in him a better and fuller statement of what he had already accepted as true, a more ample and far-reaching method, a goal of his studies in the history of thought. . . .

"Since Professor Morris never held his philosophy by a merely intellectual grasp, since it was fused with his personal character, and gained its colour and tone from 
his own deeper interests, it seems worth while to speak of his thought in relation to his other characteristic qualities,- - his love of beauty and his strong religious nature.

"All who knew him knew how genuine and deep was his appreciation of the beautiful, especially as manifested in poetry and music. In music, indeed, he had not only a theoretical appreciation, but a practical and loving knowledge. This love of the beautiful found an abiding home in the very heart of his philosophy. It gave to his thought a peculiarly elevated tone. It brought him into congenial sympathy with some of the greatest spirits of the race, notably Plato.* While he did not draw his essential intellectual nutriment from Plato, he did derive from him in large measure intellectual inspiration. He never spoke of Plato without a kindling enthusiasm, a warmth of sympathy which no other philosopher ever aroused in quite the same degree. ... It was the beauty of the spirit, the beauty of the eternal idea manifesting itself in outward form that drew Mr. Morris. The delight in this factor made his idealism poetic as well as philosophic. . . .

“'The very sense of philosophical idealism,' he says in one of his works, 'is to put and represent man in direct relation with the Absolute Mind so that its light is his strength and its strength is made his.' The firmness with which he held this truth is the key to all of his thinking. It is also the key to his attitude towards current religious beliefs. In the ordinary antithesis between the supernatural and the natural, he saw concealed the deeper truth of the antithesis of the spiritual

* Cf. American Thought from Puritanism to Pragmatism, Woodbridge Riley, pp. 155 f., 169. 
and the natural-an antithesis involving, however, a unity; the natural being only the partial and dependent manifestation of the spiritual; of such a position he found all history to be the demonstration. . . . But we do him wrong to speak of his religious faith and his philosophic knowledge as if they were two separate things capable of reacting upon each other. They were one-vitally and indistinguishably one. In this union his intellectual and moral nature had its roots-a union which made him so complete a man and his life so integral. He was preëminently a man in whom those internal divisions, which eat into the heart of so much contemporary spiritual life, which rob the intellect of its faith in truth and the will of its belief in the value of life, had been overcome. In the philosophical and religious conviction of the unity of man's spirit with the divine, he had that rest which is energy. This wholeness of intelligence and will was the source of the power, the inspiring power, of his life. It was the source of the definiteness and the positiveness of his teaching, which, free from all personal dogmatism, yet made the pupil instinctively realize that there was something real called truth, and this truth was not only capable of being known by man, but was the very life of man. . .

"No attempt can here be made to appreciate the intimate and personal qualities of Mr. Morris. Were I to attempt it, the flood of personal memories and affections would prevent. To those who did not know him, no use of adjectives would convey an idea of the beauty, the sweetness, the wholeness of his character. To those who did know him, it is not necessary to speak of these things. His gentle courtesy in which respect for others and for himself were so exquisitely blended, 
his delicate chivalry of thought and feeling; his union of intellectual freedom and personal simplicity-who shall speak adequately of these traits? The words of one who knew Mr. Morris only by his outward presence, and through the report of others, come to my ips: 'There was nothing which he held as his own; he had made the great renunciation.",

Again, looking now down the long vista of years, Professor Dewey, writing in December, 1915, gives the following estimate of his teacher and associate:

"My chief impression of Professor Morris as a teacher, vivid after the lapse of years, is one of intellectual ardour, of an ardour for ideas which amounted to spiritual fervour. His very manner as he lectured on a theme dear to him was like an exemplification of his own attachment to the Aristotelian doctrine, that the soul is the form, the entelechy, of the body. His spare and tense frame seemed but an organ for the realization of thought. The image as it stands forth in my mind today is accentuated by the fact that his energy was never vehemence. His emphasis always seemed moral rather than physical. He had vigour; his manner was never indolent; he threw himself with positiveness into his message. But his physique, though firm knit, was not of itself sufficiently vigorous, so it seemed, to account for the verve of his teaching. As his eye lit up and his face shone, there was fire without heat, energy without violence-an exhibition of the life of thought.

"I would not give the impression that he was a preacher of a message rather than a scholar. After the lapse of years it is doubtless his more exalted moments that form the material of my mental picture; it is they which are typical of his personality and his influence. But 
he was essentially the scholar in his instruction. Upon rare occasions I saw him stirred by indignation-always by some manifestation of what seemed to him insincerity, or of some display which was the equivalent of insincerity. One of these occasions was when a graduate student, whose main interest was in some other branch of learning, said that he intended to come to Professor Morris's classes as he wished to dabble in philosophy. It is quite possible that the luckless student was merely unfortunate in his choice of a term. But to Professor Morris the word 'dabble' as applied to study of philosophy seemed to sum up all that was reprehensible in a student. In part his resentment was because philosophy, a love of wisdom that to him was truly a Platonic love, was impugned. But in good measure his indignation was called forth by the intimation of any connection between scholarly study and dabbling, no matter what the topic.

"There are teachers who inspire, but their inspiration, tested by time, appears mainly emotional, and hence temporary, transient. There are scholars who are thorough and honest, but whose attitude toward their subject seems, if not perfunctory and formal, at least professional, a tradesmanlike affair. Mr. Morris was of that rarer group where scholarship blends with enthusiasm; where competent technical methods lend themselves to the support of inspiration. I cannot imagine either the student indifferent to philosophy or the student whose main concern with it was professional leaving Professor Morris's classes without having gained a respect for the disinterested play of mind,-for scholarship not as a badge of possession or external accomplishment, but as a vital concern. 
"As I go over more in detail the courses which I followed with him in the history of philosophy (at Johns Hopkins University), I recall long stretches devoted mainly to exact, orderly and lucid exposition. It was doubtless Aristotle and Hegel who called forth these exhibitions of noble ardour which remain so prominent in my memory. After I became personally more familiar with the writings of the men about whom he lectured, I was struck, upon recurring to my notes, to find how largely he conveyed each author in words chosen from the author himself; with what scholarly tact he seized upon characteristic words, and with what a sense for the logic of the author he strung them together. His exposition was conscientiously severed from his criticism, which followed hard upon it. In dealing with the British writers his criticism was severe and unfavourable-as one can gather from his British Thought and Thinkers, a book more popular in tone, thanks to its origin, than his academic lectures, but yet agreeing in a constant depreciation of English thought when compared with German. I cannot but feel that a genuinely typical significance attaches to his judgment of John Stuart Mill. The personality and the intention of Mill had a great attraction for Morris; I like to think it was because of a real kinship between the characters of the two men. But Mill's standpoint and achievement in philosophy, judged from the standpoint of the idealism so dear to Morris, repelled him. I have a feeling that his lectures betrayed the fact that he never quite forgave the English empiricists, 'externalists,' and mechanical philosophers for having, for a time, led him astray. The tone of his judgments seems coloured by his own conversion from allegiance to English philo- 
sophy. However that may be, I cannot refrain from quoting the words to which I have referred as genuinely typical; 'I conclude that J. S. Mill's greatest personal misfortune was that he was born the son of James Mill, and not of Johann Gottlieb Fichte.' The spiritual kinship which I am confident Morris felt between Mill's intention and his own thought, an intention frustrate in Mill, he found achieved in the ethical idealism of Fichte.

"It is not for me to expound the idealism which won the ardent loyalty of Morris. But I may comment upon it from the standpoint of the impressions left upon a student. It was, all the way through, an objective and ethical idealism. He effected in himself what many book-scholars would doubtless regard as impossible,-a union of Aristotle, Fichte and Hegel. The world, the world truly seen, was itself ideal; and it was upon the ideal character of the world, as supporting and realizing itself in the energy of intelligence as the dominant element in creation, that he insisted. That the struggle of intelligence to realize in man the supreme position which it occupies ontologically in the structure of the universe was a moral struggle, went without saying. The teleological metaphysics of Aristotle thus found a natural complement in the moral idealism of Fichte.

"From Hegel Morris derived his method. Speaking from the standpoint of the intellectual impression made upon a former student, I should say that he was at once strangely indifferent to and strangely preoccupied with the dialectic of Hegel. Its purely technical aspects did not interest him. But he derived from it an abiding sense of what he was wont to term the organic relationship of subject and object, intelligence and the world. 
This was the supreme instance of the union of opposites in a superior synthesis, and, as it were, vouched for the reality of the dialectic principle all along the line. As I recall the current of his teachings both in the critical parts of his lectures on the history of philosophy and in his constructive courses-such as his Real Logic,- the contrast which most frequently recurred was between a unity which excluded differences, and a unity which existed in and through differences. When he talked, as he was wont to do, of the mechanical and the organic, it was this contrast which stood forth. It was a contrast between the dead and the living, and the contrast was more moral and spiritual than physiological, though biology might afford adumbrative illustrations. His adherence to Hegel (I feel quite sure), was because Hegel had demonstrated to him, in a great variety of fields of experience, the supreme reality of this principle of a living unity maintaining itself through the medium of differences and distinctions.

"Thus it was that Morris's students were familiarized, from the standpoint of idealism, with many of the objections which realists have recently brought against idealism. I remember the scorn with which he alluded to Bain's reference to the problem of the existence of an external world as the great problem of metaphysics. To him the existence of the external and physical world was a matter of course. The philosophical problem concerned its nature, not its existence. And to have made its nature psychical, to have assimilated it to states of consciousness, would have been to contradict the very principle of spiritual unity which is sustained only through differences and oppositions overcome in living thought. To use recent terminology, epistemologically he was a realist- 
close to a common-sense realist. The idealism of nature is expressed in its teleological subordination to thought and, above all, to thought in action. Knowledge was but a manifestation of this subordination, morals being an even more adequate realization. This same spirit marked his treatment of Kant. The English and American idealism of his day and that immediately succeeding, tended to treat Kant as the source of the idealistic faith, although a source needing considerable purification. Morris, on the other hand, tended to treat him rather as a phenomenalist, an agnostic, and found the root of his unconquered subjectivism in his original 'mechanical' separation of subject and object. Possibly because my own thinking was so largely influenced by Professor Morris in this regard, it has always seemed to me that he showed a truer historical instinct in his opposition of Hegel and Kant than has that line of commentators who have treated Hegel as a Kant freed from inconsistency.

"Of Professor Morris as a teacher of undergraduates I have no direct knowledge. One thing, however, was a matter of such general repute and so typical of his personality, that I shall mention it. He had to quiz the undergraduates, an ordeal which was spared him when teaching university students. For, by all reports, it was more of an ordeal to him than to the students. He faced the operation of questioning them upon their knowledge of his lectures and the books to which he had referred them as a duty which must be undertaken. But he never seemed wholly free from embarrassment in its performance.* Part, at least, of the explanation of his attitude was obvious enough. His kindly dis-

* See above, p. 128. 
position revolted from putting others at a disadvantage. He was at the furthest remove from the teacher who loves to 'catch' his students. Failure on the part of others was a painful experience to him; he shared the humiliation-oft times more, I fancy, than it was shared by the student. If the student could not answer his question in one form, he tried another. There was no legal rule against leading questions in his class-room.

"Am 'I wholly fanciful in believing that he was moved, not only by his remarkable kindliness, but also by another force of which perhaps he was hardly conscious? I believe that all the pedagogic methods which rely upon minute questioning, tests, marks and promotions, were repugnant to him. If he had expressed his sentiment in the matter, ${ }^{*}$ I think he would have said that to submit intelligence to such treatment is foreign to its nature - that it was to reduce reason to that mechanical plane which everywhere was his abhorrence. Freedom, inspiration drawn from itself, joy in its own realization, were the very breath of the nostrils of intelligence. To deal with a student, even the average undergraduate, as anything but a potential intelligence was an aversion to him. As a member of the faculty he always stood enthusiastically for everything which promoted 'university' as distinct from 'college' work. Perhaps the development of higher instruction in America has been sometimes influenced by the ordinary external motives which move human nature: sense of prestige, and the like. Not so with Professor Morris. His belief in the methods of university work, in intellectual freedom and stimulation from the inquiry in hand, was profound and intrinsic. They were to him the only methods compat-

* He comes very near doing so on p. 299 above. 
ible with the dignity of intelligence. I may be wrong in thinking that he was the originator of the so-called 'university' method for undergraduates; a method which enabled them to specialize from the Junior year on, and which freed them from the ordinary rules about attendance and examinations, treating them, in short, as graduate students were treated. But I am not wrong in thinking of him as among its most ardent supporters. The scheme did not work out as well as he hoped. It gradually fell into disuse-a fact which grieved him. But he never lost faith in its essential soundness for the élite of the undergraduate body. And no one who came profoundly under his influence, whether accepting his type of technical philosophy or not, has ever lost the sense that genuine intellectual activity means a spirit of freedom and an inspiration drawn from within, not from external and mechanical supports. His own teaching incarnated this ideal. The joy he experienced in study and reflection was evident and impressive.

"Even after twenty-five years, I find it difficult to speak of Mr. Morris as a friend with complete selfpossession. He was kindness itself in all human relations. He was gentleness in person-a gentleness which never suggested weakness. He occasionally referred to the repressive effects of his early Puritan education, and deplored its result in discouraging all easy demonstration of the affections. Yet, while there was reserve in his manner, there was no constraint. Whatever inner embarrassments he may once have felt, he had transmuted them into self-possession. There were, if I may use the expression, no loose ends in his bearing, nothing excessive nor flabby; there was some- 
thing classic in his simplicity and self-possession. He never imposed himself upon others by self-assertion, but no one would have thought of taking advantage of him, or of treating him as negligible in any situation. What he was not informed about, topics about which he had not carefully thought, he left alone. When he expressed himself, his bearing as well as his words commanded respect.

"Kindly time performs its sweet offices for all human relationships. The petty and the trivial fall away in our recollections of any sincere and forceful personality. Dross is purged, and the real man stands out unalloyed. I have never known anyone less in need of this purging office of memory than Mr. Morris; in his case the idealized portrait and the man of the round of ordinary daily occupations fuse insensibly and naturally into one." The late Professor Hough and, again, Professor Dewey, enable us to approach more closely to the method, manner and importance of the work performed by Morris as a teacher. The former tells us:*

"Professor Morris was one of the high type of teachers who draw the interest and thought of their students to the work, rather than force the work upon them. He was an inspirer and guide, not a master. But he did not inspire his hearers by eloquence; he cared little for such effects. You were rather drawn to him and to his teaching by his transparent goodness, his perfect simplicity and sincerity, by the charming, almost fascinating, sweetness of his manner, but above all, I think, by the real substance of what he said, and by the illumination, the flood of light, which his mind always cast upon his theme. Thus if I were asked to say in a word what it

* The Chronicle, Vol. XX., pp. $245 \mathrm{f}$. 
was that drew you most to him, I should say it was the beauty of light, the attractive force and satisfaction of light, as conveyed in his thought, and as manifested in his person and presence.

"For distinctively university teaching, Professor Morris possessed the highest qualifications. Not only was his own culture of the broadest and most truly liberal sort, but all his work was conceived and done in a university spirit. Education in the real and true sense of self-unfolding, he could conceive of as normally taking place only in a true university. In a true development the motive and the inspiration come from within, and are not imposed from without. Such a development a university invites and fosters. Here the instruction is but the opportunity; it may kindle the spark, but the flame must burn from within. A true development, too, must be many-sided, and still harmonious and organic; it implies what we call culture, and at the same time that intelligence which springs only from a due appreciation of the proper relations of things. This, again, the university, affording with its many departments instruction in every branch of knowledge, and yet always pursuing it in the spirit and purpose of the whole-the attainment of true intelligence-is alone adequately fitted to give. True education finds its best opportunity and greatest encouragement in a true university. No one could have been more awake to the priceless value of such a broad, balanced, intelligent knowledge of one's self and of life, than was Professor Morris. And so strenuous and constant was his effort, not only to conduct his own work in this spirit and with this aim, but also to inculcate this idea in others, and to permeate the whole work of our University with it, that his value 
and services for distinctly university teaching were inestimable. No one ever listened to his instruction, who has not felt the broadening, enlightening influence of this idea, and been permanently elevated and expanded by it.

"Of the content of Professor Morris's teaching, his philosophical views, it is beyond the purpose of these few paragraphs to speak, even in the most general terms. But it may be permitted to allude very briefly to the important place he occupies in the history of philosophical instruction in this country. $\mathrm{He}$ was one of the earliest, and perhaps has done more than any other, to make current among us a measurably comprehensive and adequate knowledge of the History of Philosophy, at first by the translation of Ueberweg's standard work on that subject, further by making his own historical lectures an established part of his philosophical instruction, and later by editing a series of critical expositions of the masterpieces of German philosophy, to which he himself contributed two volumes. The last two decades have witnessed an almost complete change in the content and method of philosophical instruction in this country. Instead of the circumscribed, traditional doctrines, which were held and taught largely in the service of theology, nearly every branch of philosophy is now pursued in a historical spirit, and treated on its own account. And I suppose it is true today that no one has borne a more visible hand in this transformation than Professor Morris."

Mr. Dewey is no less definite.*

"There is, indeed, nothing to be said of him as a class-room instructor that is not to be said of him as a

* The Palladium, Vol. XXXI., pp. $117 \mathrm{f}$. 
man. Nothing could have been more foreign to his character than to assume in any respect an attitude or quality in the class-room different from that which marked him elsewhere. There was the same sincerity, the same simplicity, the same force of enthusiasm in him in one place as in another. No 'officialism,' such as sometimes gathers about the work of teaching, ever touched him. He was everywhere simply and only a man.

"But Professor Morris had unusual gifts as a philosophic instructor. He was, among other things, a commentator of the first order. That is, he had the selective eye which made at once for the heart of an author under discussion; he had the pregnant phrase that lays bare this heart to the eye of the student. $\mathrm{He}$ had the gift of inspiring in his pupils the same disinterested devotion to truth that marked himself. $\mathrm{He}$ conveyed in large measure what, in his essay upon University Education, he himself calls 'the power to detect and the will to condemn all essential shams and falsehoods.' Scholarship never lost itself in pedantry; culture never masqueraded as mere intellectualism, without ethical inspiration and backing. He was especially successsful in arousing pupils with any particular aptitude for philosophy to advanced and independent work. The spirit of his work was that which he declared should be the spirit of all truly University work - a free teacher face to face with a free student. He once defined idealism as faith in the human spirit; this faith he had, and his voice and his influence were always for broadening the scope and methods of college work, without in any way relaxing the solidity and thoroughness of mental discipline. 
"Of the place and function of philosophy in University training, he had a high conception-not because he would in any way magnify his own office at the expense of others, but because he saw in philosophy the organic bond of all the special sciences, "the coördination of all knowledge.' . . . So far was he from desiring any exclusive treatment of philosophy, that he writes that 'her praises will never be rightfully and effectively sung until they are sung by others than adepts.' I can find no better expression of the spirit in which Professor Morris himself taught philosophy than is voiced in one of his own earlier writings. He speaks there of 'the noblest common-sense, which seeks reform, not simply protest and the demand for change, but by fitly feeding the fountains of intelligence, through which alone a true and authentic reform can be maintained.' To feed the fountains of intelligence was precisely, it seems to me, the work of Professor Morris in philosophy. While we cannot estimate the loss to thought in his sudden death, we cannot be sufficiently grateful that there are so many scattered over the whole land who have felt the quickening touch of his divine love of truth, and who have felt the 'fountains of intelligence' within their own breast, called into life and energy by the truth as he bore witness to it."

These illuminating tributes and appreciations serve to convey some idea of the rare quality of the man, and of the important place to which he had won so nobly.

They also intimate that, while his early death was a staggering blow to his friends and a grievous loss to the University of Michigan, it was, even more, in Professor Dewey's words, 'a loss no less deep to the philosophical world at large. He was in the prime of his work. His 
feeling as expressed in one of those rare moments when he broke through his accustomed reserve, was that in past work he had been serving an apprenticeship for what he hoped to do.'

We have our external memorials of him: the reading and seminary rooms, furnished artistically by Mrs. Morris, enriched by her, for practical uses, with her husband's library; the fund set aside by her to aid promising students in philosophy and to make additions to our resources in books. Most fittingly, too, in the alterations of 1893, which rendered St. Andrew's Church, Ann Arbor, a place where men can worship the Lord in the beauty of holiness, Morris was not forgotten.

"Within the chancel the changes are quite marked. The altar has been enlarged and elevated to its proper position. An altar piece has been provided, consisting of an 'alto relievo' of the Last Supper, after Leonardo da Vinci. This relievo, which is seven feet long, and of proportionate height, is finished in soft old ivory tints, which bring out the delicately modelled features to perfection. It forms a recessed panel in a plain battlemented reredos, which rises to the sill of the large east window. This whole work, including the reredos and relievo, is a memorial to the distinguished metaphysician and man of God, the late Professor George S. Morris."*

But, after all, "the humane sweetness of the man which, nevertheless, did not prevent him from holding positive opinions and exhibiting great courage in their expression," as Dr. Angell says, has its best memorial in the Department of Philosophy, whose pathway to real influence Morris was the first to blaze. We follow him in the difficult attempt to be worthy of his memory,

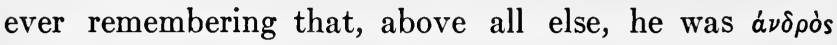

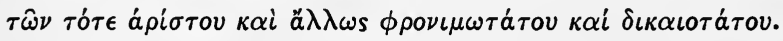

* A History of St. Andrew's Church, Ann Arbor, Michigan, Arthur Lyon Cross, pp. 130-1. 


\section{INDEX}

Academy, Kimball Union, 39 f., $44,48,51,54,58,60,67,78$, $180 \mathrm{f}$.

Academy, Royalton, $62 \mathrm{f}$.

Adam, J., 31.

Adams, C. K., 123, 127, 170 f.

Adamson, R., VIII., 167, 174, 254, 261.

Alexander, S., 285.

Andover Theological Seminary, 79 .

Angell, J. B., V., VIII., 124, 125, $127,128,131,134,137,138,141$, $147,154,157,163,164,326$.

Angell, Mrs. J. B., 128, 134.

Aristotle, 111, 113, 117, 130, 135, $144,154,167,207,221$ f., 235 , $240,242,259,264,292,313,315$, 316.

Astié, F., 111.

Astronomy, 51, 60, 64 f., $198 \mathrm{f}$.

Athens, 31 f.

Auburn Theological Seminary, 67, $69,78 \mathrm{f}$.

Bacon, 244, 250.

Bain, A., 309, 317.

Baltimore, Md., 142 f.

Barnes, A., 89.

Baxter, R., 18.

Bebel, A., 11.

Beckley, H., 35, 37.

Beecher, L., 89.

Benedict, G. G., 74 f.

Berkeley, 252, 304.

Berlin, 112 f., 169, 217 f.

Bethel, Vt., 8.

Beyschlag, W., 110.

Birney, J. G., 36.

Black, J. S., 292, 293.

Blunt, E. L., 30.

Boardman, S. W., $78 \mathrm{f}$.

Booth, H. M., 92.

Bosanquet, B., 107, 273.

Bowdoin College, $131 \mathrm{f}$.

Bradley, F. H., 145, 167, 254, 270, 285.

Bradstreet, S., 17.
Bratuschek, E., 223.

Brewster, W., 17.

Brigade, Second Vermont, $74 \mathrm{f}$.

Britannica, Encyclopaedia, XIV., 144.

British Hegelians, 217, $252 \mathrm{f}$., 284 f., 287, 291, 318.

British Museum Catalogue, XV.

British Philosophy, 251 f., 265 f., $309 \mathrm{f}$.

British Science, $246 \mathrm{f}$.

British Thought and Thinkers, 141, 144,243 f., 256 f., 308 f., 315.

Brooks, W. K., 152.

Brown, E. E., 302, 306 f.

Browning, 254, $273 \mathrm{f}$.

Büchner, L., 226, 231.

Bunyan, 3, 18, 58 .

Burke, 98.

Burt, B. C., XV., 146, 152, 155, $173,284$.

Butler, S., 16.

Caird, E., VIII., 52, 167, 170, 174, $188,244,253$ f., $274,277,284$ f., 297.

Caird, J., VIII., 52, 165, 170, 254 f.

California, University of, 134.

Calvin, 191.

Calvinism, 189 f., 207, 210 f., 216, $245,257,281,287$.

Carlyle, 4, 92, 155, 161, 246, 254.

Campbell, A., 141, 155 f., 239.

Catalogue, British Museum, XV.

Channing, C., 23.

Chapin, L. D., 114.

Chrystal, G., $293 \mathrm{f}$.

City College, New York, 134.

Civil War, the, $68 \mathrm{f}$.

Clark, W., $174 \mathrm{f}$.

Clay, H., 8.

Cleveland, G., 11.

Clough, A. H., 87.

Cocker, B. F., XIV., 135 f., 141, $146,156,159,160$.

Coleridge, 107, 215, 254.

College, Bowdoin, $131 \mathrm{f}$. 
Dartmouth, 15, 36, 43, 45 f., 51,54 f., $71,76,79$ f., 88 , $90,181,183,185 \mathrm{f} ., 193$, 197 f., 206, 297.

New York City, 134.

Conciliation, School of, 99, 111, $195,210 \mathrm{f}$.

Cone, Mrs. K. M., VIII., 9, 11, 12, 21,35 f., $39,40,48$ f., 100,105 , $118 \mathrm{f}$.

Congregationalism, 24, 29, 35, 42, $56,86,206,289$.

Conscience, the New England, 2, $55,69,86$ f., $189,206,216,223$, $227,262,264,280$.

Converse, C. B., 75.

Cornell University, $170 \mathrm{f}$.

Cotton, J., 17.

Cox, G., 62, 68, 69, $71 \mathrm{f}$.

Criticism, Historical, $224 \mathrm{f}$.

Croce, B., 240.

Cromwell, 17.

Cross, A. L., 326.

Curtis, E. H., 88, 96 f.

Culture of New England, $1 \mathrm{f}$., $18 \mathrm{f} ., 34 \mathrm{f} ., 113,177 \mathrm{f}$.

Dartmouth College, 15, 36, 43, 45 f., 51, 54 f., 71, 76, 79 f., 88, $90,181,183,185$ f., 197 f., 206 , 297.

Dartmouth, N. H., 10.

Darwin, C. R., 161, 207, 227 f., $247 \mathrm{f}$.

Darwin, G. H., 11.

Davis, R. C., 180 f.

Declaration of Independence, 19

De Laguna, T., 287.

Demmon, I. N., 127.

Democritus, 221.

Dennison, Alice, 63.

Dennison, C. S., 63, 159.

Dennison, J. A., 104.

Dennison, Susan, 104 f., 115 f.

Descartes, 136, 265.

Dewey, J., 121, 146, 157, 160, 302, 304,308 f., 313 f., 321,323 f.

D'Ooge, M. L., 90.

Drama, the, $72 \mathrm{f}$.

Dresden, 110.

Droysen, J. G., 283.

Dudley, T., 17, 19.

Edison, T., 11.
Edwards, J., 239.

Eliot, J., 45.

Ely Lectures, 145, 255, 261, $270 \mathrm{f}$.

Encyclopaedia Britannica, XIV., 144.

Erdmann, J. E., 168 f.

Eucken, R., 118.

Everett, C. C., VIII.

Evolution, 204.

Fairbairn, A. M., 167, 170.

Family, influence of the, $25 \mathrm{f}$.

Farrar, F. W., 157.

Ferrier, J. F., 215, 252.

Feuerbach, L., 221, 226.

Fichte, I. H., 218, 233, 257.

Fichte, J. G., 144, 168, 281, 316.

Final Cause, Morris on, 233 f., $241 \mathrm{f}$.

Fischer, K., 169, 220.

Flint, R., 147 f., 165, 170.

Fortlage, C., 220.

Foster, F. H., 189, 209.

Fraternity, Psi Upsilon, 51, 197.

Frieze, H. S., V., 122 f., 133 f., 141, $153,159,160$.

Galton, F., 1.

Garfield, J. A., 68.

Garibaldi, 205.

Garrison, W. L., 36.

Gayley, C. M., 165 f.

Geology, 64, 198, 232.

German Philosophical Classics, Morris edits, 144, 173, $261 \mathrm{f}$.

Gilman, D. C., 138 f., 148 f.

Goethe, 276.

Goodhue, H., 81.

Graham, H. G., 239.

Graves, A. A. (see Mrs. Wilson).

Green, T. H., VIII., $11,165,167$, $194,227,253$ f., $274,277,284$ f.

Grote, J., 252.

Haldane, Lord, 165, 253, 291.

Hall, G. S., XV., 142, 145, 150, 152 f., 258.

Halle, 109, 217 f.

Hamilton, 113, 207.

Hamman, 224.

Hampden, 17.

Harris, W. T., VIII., XIV.

Hartmann, E. v., 226, $235 \mathrm{f}$.

Haselrig, 17. 
Haven, E. O., V., f., 123,f., 135, 156

Haynes, J., 17.

Hedge, F. H., 212.

Heine, 232.

Hegel, XV., 107, 113, 117, 136, $144,145,153,163,168$ f., 173 , $192,226,227,235,238,239$, $240,253,255,258,264,269,278$, 282 f., 288, 292, 296, 304, 306, $310,315,316 \mathrm{f}$.

Hegelians, British, 217, 252 f., 284 f., 287, 291, 318.

Helmholtz, 219.

Henkel, H., 248.

Herder, 22.

Hinsdale, B. A., V.

Historical Criticism, $224 \mathrm{f}$.

Hitchcock, R. D., 90.

Hoar, Senator, 3.

Hodgson, S. H., 108, 111, 180, $214 \mathrm{f}$.

Höffding, H., 257, 258.

Holbrook, Governor, 74.

Home, the New England, $11 \mathrm{f}$., $34 \mathrm{f}$.

Hooker, T., 17.

Hough, W. S., 160, 168 f.; 174 $297,321 \mathrm{f}$.

Howison, G. H., 157, 160, 162.

Humboldt, A. v., 219.

Hume, 96, 128, 195, 215, 227, 259, $264,265,268,290,304$.

Hutchinson, S., 75.

Hutton W., 90 f., $97 \mathrm{f}$.

Hyslop, J. H., 213.

Ide, H. C., 80 f.

James, W., 11, 286.

Joël, L., 112, 132, 141, 170, 174.

Johns Hopkins University, XIV., 49, 138 f., 144 f., 162.

Journal, Private, of Morris, 183 f., $199 \mathrm{f}$., 201.

Jowett, B., 187 f., 201.

Kant, XIII., 17, 92, 96, 120, 135, $142,144,145,151,156,157,162$, $163,168,215,223,227,232,233$, $239,240,243,251,255,258$, 259 f., 263 f., $288,304,310,316$, 318.

Kant's Critique of Pure Reason,
Critical Exposition of, by Morris, $144,263 \mathrm{f}$.

Keats, 58.

Kimball, D., 182 f.

Kimball Union Academy, 39 f., 44, $48,51,54,58,60,67,78,180$ f.

Königsberg, University of, 121.

Lang, A., 11

Lange, F. A., 107, 227.

Larrowe, M. D., VII., 101 f., 116.

Lasson, A., 169.

Laud, 19.

Lausanne, $111 \mathrm{f} ., 170,173,174$.

Leibniz, 219.

Lewes, G. H., 163, 207.

Liebig, 219.

Lincoln, 73.

Locke, 19, 105, 239, 244, 259, 295.

'Loisette, Alphonse,' $102 \mathrm{f}$.

Lord, Nathan, 15 f., 46 f., 50, 185.

Long, C., $49 \mathrm{f}$.

Lotze, H., 218, $262 \mathrm{f}$.

Lutheran Theology, $190 \mathrm{f}$.

Lux Mundi, 277.

McCosh, J., 145, 196.

Mackenzie, J. S., 285.

Mackintosh, R., 293.

Man, Morris as a, $296 \mathrm{f}$.

Mansel, H. L., 174, 207.

Marsh, J., 107, 196.

Marquand, A., 140.

Mazzini, 246.

Memory Systems, 103.

Merriam, S. A., 46.

Merrill, C. H., 81.

Merritt, A. K., 103.

Merz, J. T., 130, 247.

Michigan Philosophical Society, $156,164 \mathrm{f}$.

Michigan, University of, V. f., XV., 90, 119, 122 f., 139 f., 147, 153,159 f., $173,176,283,325$.

Mill, J. S., 128, 130, 163, 207, 309, $315 \mathrm{f}$.

Milton, 18, 105.

Mind, 167, 261, 296, 297.

Miracles, 222.

Moore, E. C., 271.

Morgan, J. P., 11.

Morris, Ethel, VII., 97, 143.

Morris, Ephraim, $13 \mathrm{f}$.

Morris, George Sculthorpe, XV. 
Morris, George Sylvester, -

Ancestry of, $4 \mathrm{f}$., 27.

Birth of, 10.

and the Church, $42 \mathrm{f}$., 69 , $96 \mathrm{f} ., 134$.

in the Civil War, $71 \mathrm{f}$.

his British Thought and Thinkers, 141, 144, 243 f., 256 f., $308 \mathrm{f}$., 315.

at Dartmouth College, $45 \mathrm{f}$.

Death of, $175 \mathrm{f}$.

Education of, 34f., 88f., 109 f.

his Ely Lectures, 145, 255, 261, $270 \mathrm{f}$.

Europe, visit to, $165 \mathrm{f}$.

on Final Cause, 233 f., $241 \mathrm{f}$.

his German Philosophical Classics, 144, 173, $261 \mathrm{f}$.

in Germany and Switzerland, 108 f.

his Hegel's Philosophy of the State and of History, $282 \mathrm{f}$.

at Johns Hopkins University, $138 \mathrm{f}$., $146 \mathrm{f}$.

at Kimball Union Academy, $39 \mathrm{f}$.

his Kant's Critique of Pure Reason, Critical Exposition of, 144, $263 \mathrm{f}$.

Man, as a, $296 \mathrm{f}$.

Marriage of, 143.

Memorials to, 159, 326.

and music, $38 \mathrm{f}$., $58 \mathrm{f}$., 79,109 , $112,125,132$ f., 153,168 , 175.

on Philosophy and its Specific Problems, 259 f.

on preaching, $93 \mathrm{f}$., $115 \mathrm{f}$.

Private Journal of, $183 \mathrm{f}$., 199 f., 201.

read widely, 59,65 f., 92 , $207 \mathrm{f}$., 224.

at Royalton Academy, $62 \mathrm{f}$.

on Shakespeare, $72 \mathrm{f}$.

Teacher, as a, $302 \mathrm{f}$., $313 \mathrm{f}$., $321 \mathrm{f}$.

Thesis for M. A., $82 \mathrm{f}$.

Thinker, as a, $253 \mathrm{f}$.

on Unconscious Intelligence, $235 \mathrm{f} ., 241 \mathrm{f}$.

Ueberweg, translation of, 120 f., $132 \mathrm{f}$.

on University Education, 180, 298 f., 324. at the University of Michigan, 176.

and the Victoria Institute, London, $229 \mathrm{f}$., $241 \mathrm{f}$.

Verses by, $53 \mathrm{f}$., 85, $92 \mathrm{f}$.

Writings of, early, 43 f., $52 \mathrm{f}$., 63 f., 82 f., 93 f., 197 f., $202 \mathrm{f}$.

Writings, published, XI., f.

Morris, Mrs. G. S., VII., 103, 143.

Morris, Kate (see Mrs. K. M. Cone).

Morris, Lucy, 38 f., 57, 61, 77 f., $100,118$.

Morris, Roger S., 143, 175.

Morris, Susanna Weston, 9, 37 f., $50,57,76$ f., 113.

Morris, Sylvester, 4, 8, 11, 12 f., 21,35 f., 100 f., $119,173$.

Morris, Tyler S., 5 .

Morrison, H. C., 39 f.

Muirhead, J. H., 174.

Natural Theology, $199 \mathrm{f}$.

New England Conscience, the, $2,55,69,86$ f., $189,206,216$, $223,227,262,264,280$.

New England, Culture of, $1 \mathrm{f}$., $18 \mathrm{f}$., $34 \mathrm{f}$., $113,177 \mathrm{f}$.

New England Home, the, $11 \mathrm{f}$, $34 \mathrm{f}$.

New England Sermons, 29.

New England Theology, 189 f., 209 f., 250 f.

'New School' Presbyterianism, $89 \mathrm{f}$.

New York, 88 f., 119 f.

New York, City College of, 134.

Neo-Fichteans, 219, 223, 229, 233 , 257.

Neo-Kantianism, 152, 168 f., 218, $220,252 \mathrm{f}$.

Newton, 227, 247, 265.

Nichol, J., 286.

Nietzsche, F., $225 \mathrm{f}$.

Norwich, Vt., 10, 14, 34, 42, 62 , $78,101,164$.

Norwich University, 35 f.

Olney, E., V.

'Original Research,' 149 f.

Osborn, H. F., 161.

Oxford University, 167 f., 285. 
Paley, W., 96, 199 f.

Partridge, Alden, 33, 40.

Partridge, Lewis, $35 \mathrm{f}$.

Patterson, J. W., 60.

Pfleiderer, O., 169, 170, 209, 211.

Philosophical Classics, German, 144, 173, $261 \mathrm{f}$.

Philosophy, British, 251 f., 265 f., $309 \mathrm{f}$.

Philosophy and Christianity (Ely Lectures), 145, 255, 261, $270 \mathrm{f}$.

Philosophical Society, Michigan, 156, $164 \mathrm{f}$.

Philosophy, specific problems of, Morris on, $259 \mathrm{f}$.

Pierce, C. S., 142, 145, 148.

Pilgrim, 1 f., 9.

Plato, 28, 31, 135, 137, 154, 167, $197,200,221$ f., $239,240,259$, $264,310$.

Pownall, Governor, 105.

Prentiss, G. L., 89, 107.

Presbyterian, 'New School,' $89 \mathrm{f}$.

Private Journal of Morris, $183 \mathrm{f}$., 199 f., 201.

Psi Upsilon Fraternity, 51, 197.

Puritans, $1 \mathrm{f}$.

Puritanism, 17 f., 37 f., 85 f., 100 f., 105 f., 189 f., $216,223,245$, $277,280,285,288,320$.

Putnam, J. N., 49, 51.

Rebec, G., 158 f.

Redington, E. O., 297.

Regiment, 16th Vermont, $74 \mathrm{f}$.

Reid, T., 195.

Renan, 31, 207, 225.

'Research, Original,' $149 \mathrm{f}$.

Richards, C. S., 41 f., 60,180 f.

Riley, W., 27, 184, 195, 196, 204, $238,295,310$

Ritchie, D. G., 249.

Ritschl, A., 209.

Ritschlianism, 168, 193.

Robertson, G. C., 167, 168.

Romanes, G. J., 249.

Rome, 114.

Rousseau, 19, 289.

Royalton, Vt., 61, 79, 104, 115, 198, 201, 202 f.

Royalton Academy, $62 \mathrm{f}$.

Royce, J., 139, 145.
St. Andrew's Church, Ann Arbor, $134,159,326$.

Sage Foundation, 173.

Santayana, G., 295.

Schaff, P., 111, 120, 133, 192, 195.

Schelling, 144, 168, 219 f., 226, 237.

Schleiden and Schwann, 219.

Schleiermacher, 117, 195, 210 f., 221, 232.

School of Conciliation, 99, 111, $195,210 \mathrm{f}$.

School, Tübingen, 225.

Schopenhauer, 226.

Schwarz, C., 219, 225.

Schweitzer, A., 210.

Science, British, $246 \mathrm{f}$.

Scottish School, 195 f., 209, 239.

Second Vermont Brigade, $74 \mathrm{f}$.

Seligman, J., 119, 153.

Seth, A., 291.

Shakespeare, 72 f., 93, 245.

Shattuck Observatory, 51, 60, $201 \mathrm{f}$.

Shedd, W. G. T., 89, 90, 107.

Shepard, T., 17.

Sidgwick, H., 11.

Sibler, E. G., 139.

Slavery, $13 \mathrm{f}$., $46 \mathrm{f}$., $68 \mathrm{f}$.

Smith, B. P., $46,47$.

Smith, H. B., 88,90 f., 96 f., 110 f., 120,131 f., $153,195,196$, 206, 208, 209 f., 218, 222.

Smith, W. R., $293 \mathrm{f}$.

Socrates, 31, 239, 259.

South Wilbraham, Mass., $6 \mathrm{f}$.

Spencer, H., 128, 163, 207, 240, 244, 246, 248, 259, 263, 309.

Spinoza, XIII., 136, 144, 237, 259, $265,289$.

Stebbins, H. H., 89 f.

Sterrett, J. M., 296 f.

Stirling, J. H., VIII., 107, 200, 254.

Stone, M. S., 62.

Stoughton, General, 74.

Strauss, D. F., 107, 210, 212 f., $220 \mathrm{f}$.

Swinburne, 11.

Symonds, H., 174

Taine, H., 229.

Tappan, H. P., V., 114 f., 123 f., 134 f., 156, 160.

Taylor, A. E., 285.

Taylor, F. M., 146. 
Teacher, Morris as a, $302 \mathrm{f} ., 313 \mathrm{f}$., $321 \mathrm{f}$.

Temperance Reform, 13, 15, 36, $40,76 \mathrm{f}$.

Ten Brook, A., V. f., 114, 122 f., 135.

Theological Seminary, Andover, 79.

Theological Seminary, Auburn, 67, $69,78 \mathrm{f}$.

Theological Seminary, Union, XIV., 79, 88 f., 100, 106 f., 145, $153,175,206$ f., 209 f., 240, 270.

Theology, Lutheran, $190 \mathrm{f}$.

Theology, Natural, 199 f.

Theology, New England, 189 f., 209 f., $250 \mathrm{f}$.

Theology, Reformed, 190 f., 198.

Tholuck, F. A., 99, 110, 195, 210.

Thompson, Z., 35 .

Trendelenburg, A., XII., 112, 113, $117 \mathrm{f.}, 130,144,154,177,195$, 206, 208, 210 f., 217 f., 228 f., 233 f., 240, 274, 292, 310.

Tschaikowsky, 11.

Tübingen School, 225.

Tucker, W. J., 44 f., 48 f., 52, 67, 177.

Tyler, M. C., 24, 29, 127, 159, 165, 172.

Ueberweg, F., XI. f., 120 f., 132 f., $153,177,222,228,235$.

Ulrici, H., 99, 109 f., 195, 208, 210 f., 217 f., 228 f., $233,243$.

Unconscious Intelligence, Morris on, $235 \mathrm{f}$., $241 \mathrm{f}$.

Union Theological Seminary, XIV., 79, $88 \mathrm{f} ., 100,106 \mathrm{f}$., $145,153,175,206$ f., 209 f., $240,270$.

Unitarianism, 23.

Universalism, 35.

University of California, 134.

University, Cornell, $170 \mathrm{f}$.

University Education, 180, 298 f., 324.
University, Johns Hopkins, XIV., 49, 138 f., 144 f., 162.

University of Königsberg, 121.

University of Michigan, V. f., XV., $90,119,122$ f., 139 f., 147,153 , 159 f., 173, 176, 283, 325.

University, Norwich, Vt., $35 \mathrm{f}$.

University of Oxford, 167 f., 285.

University of Wisconsin, 134.

Uphues, K., 168.

Vaihinger, H., 168, 227.

Van Tyne, C. H., 98.

Vatke, W., 107.

Veazey, W. G., 71, 75.

Vermont newspapers, XI.

Vermont Second Brigade, $74 \mathrm{f}$.

Vermont Sixteenth Regiment, $74 \mathrm{f}$.

Victoria Institute, London, $229 \mathrm{f}$.

Victoria Institute Addresses, $241 \mathrm{f}$.

Vienna, 114.

Virgil, 84.

Volkelt, J., 235.

Voltaire, 128, 130.

Walker, E. C., 122.

Walker, W., 14.

Wallace, W., VIII., 167, 168, 170, 174, 187 f., 254, 278.

Walter, E. L., 140, 298.

Watson, J., V., 127, 254.

Webster,A. G., 154.

Webster, Daniel, 8.

Weston, Susanna (see Morris, Susanna Weston).

White, A. D., 123, 125, 171.

Whitefield, 23.

Williams, M. H., 98.

Wilson, Mrs. H. B., $320 \mathrm{f}$.

Windelband, W., 226.

Wisconsin, University of, 134.

Wisdom, 28.

Wise, J., 19.

Wundt, W., 155, 168.

Zeller, E., 111, 169, 218.

Zola, 11.

Zwingli, $190 \mathrm{f}$. 


\title{
University of Michigan Studies
}

\author{
HUMANISTIC SERIES
}

\section{General Editors: FRANCIS W. KELSEY and HENRY A. SANDERS}

Size, $22.7 \times 15.2 \mathrm{~cm} . \quad 8^{\circ}$. Bound in cloth

Vol. I. Roman Historical Sources and Institutions. Edited by Professor Henry A. Sanders, University of Michigan. Pp. viii +402 . $\$ 2.50$.

\section{CONTENTS}

1. The Myth about Tarpeia: Professor Henry A. Sanders.

2. The Movements of the Chords Chanting the Carmen Saeculare: Professor Walter Dennison, Swarthmore College.

3. Studies in the Lives of Roman Empresses, Julia Mamaea: Professor Mary Gilmore Williams, Mt. Holyoke College.

4. The Attitude of Dio Cassids toward Epigraphic Sodrces: Professor Duane Reed Stuart, Princeton University.

5. The Lost Ерiтомe of Livy: Professor Henry A. Sanders.

6. The Principales of the Early Empire: Professor Joseph H. Drake, University of Michigan.

7. Centurions as Substitute Commanders of Auxiliary Corps: Professor George H. Allen, University of Cincinnati.

Vol. II. Word Formation in Provençal. By Professor Edward

L. Adams, University of Michigan. Pp. xvii +607 . $\$ 4.00$.

Vol. III. Latin Philology. Edited by Professor Clarence Linton Meader, University of Michigan. Pp. vii+290. $\$ 2.00$. Parts Sold Separately in Paper Covers:

Part I. The Use of idem, ipse, and Words of Related Meaning. By Clarence L. Meader. Pp. 1-111. $\$ 0.50$.

Part II. A Study in Latin Abstract Substantives. By Professor Manson A. Stewart, Yankton College. Pp. 113-78. \$0.40.

Part III. The Use of the Adjective as a Substantive in the De Rerdm Natura of Lucretids. By Dr Frederick T. Swan. Pp. 179-214. $\$ 0.40$.

Part IV. Autobiographic Elements in Latin Inscriptions. By Professor Henry H. Armstrong, Drury College. Pp. 215-86. $\$ 0.40$.

\section{THE MACMILLAN COMPANY}

Publishers 


\section{University of Michigan Studies-Continued}

Vol. IV. Roman History and Mythology. Edited by Professor

Henry A. Sanders. Pp. viii+427. \$2.50.

Parts Sold Separately in Paper Covers:

Part I. Studies in the Life of Heliogabalus. By Dr. Orma

Fitch Butler, University of Michigan. Pp. 1-169. \$1.25.

Part II. The Mrth of Hercoles at Rome. By Professor John

G. Winter, University of Michigan. Pp. 171-273. \$0.50.

Part III. Roman Law Stddies in Livy. By Professor Alvin E.

Evans, Washington State College. Pp. 275-354. \$0.40.

Part IV. Reminiscences of Ennids in Silids Italicus. By Dr. Loura B. Woodruff. Pp. 355-424. \$0.40.

Vol. V. Sources of the Synoptic Gospels. By Rev. Dr. Carl S. Patton, First Congregational Church, Columbus, Ohio. Pp. xiii +263 . $\$ 1.30$.

Size, $28 \times 18.5 \mathrm{~cm} . \quad 4$ to.

Vol. VI. Athenian Lekythoi with Outline Drawing in Glaze VarNish on a White Ground. By Arthur Fairbanks, Director of the Museum of Fine Arts, Boston. With 15 plates, and 57 illustrations in the text. Pp. viii+371. Bound in cloth. $\$ 4.00$.

Vol. ViI. Athenian Lekythoi with Ottline Drawing in Matt Color on a White Ground, and an Appendix: Additional Lekythoi with Outline Drawing in Glaze Varnish on a White Grodnd. By Arthur Fairbanks. With 41 plates. Pp. $x+275$. Bound in cloth. $\$ 3.50$.

Vol. ViII. The Old Testament Manuscripts in the Freer Collection. By Professor Henry A. Sanders, University of Michigan. With 9 plates showing pages of the Manuscripts in facsimile. Pp. viii+357. Bound in cloth. \$3.50.

Parts Sold Separately in Paper Covers:

Part I. The Washington Manuscript of Detteronomy and Joshta. With 3 folding plates. Pp. vi +104. \$1.25.

Part II. The Washington Mandscript of the Psalms. With 1 single plate and 5 folding plates. Pp. viii +105-357. $\$ 2.00$.

\section{THE MACMILLAN COMPANY}

Publishers 


\section{University of Michigan Studies-Continued}

Vol. IX. The New Testament Manuscripts in the Freer ColLECTION. By Professor Henry A. Sanders, University of Michigan.

Part I. The Washington Manuscript of the Fodr Gospels. With 5 plates. Pp. vii +247 . Paper covers. $\$ 2.00$.

Part II. The Washington Fragments of the Epistles of Padt. (In Preparation.)

Vol. X. The Coptic Mandscripts in the Freer Collection. By Professor William H. Worrell, Hartford Seminary Foundation. Part I. A Fragment of a Psalter in the Sahidic Dialect. The Coptic Text, with an Introduction, and with 6 plates showing pages of the Manuscript and Fragments in facsimile. Pp. xxvi +112 . $\$ 2.00$.

Vol. Xi. Contributions to the History of Science. (Parts $I$ and II ready.)

Part I. Robert of Chester's Latin Translation of the Algebra oF AL-Khowarizmi. With an Introduction, Critical Notes, and an English Version. By Professor Louis C. Karpinski, University of Michigan. With 4 plates showing pages of manuscripts in facsimile, and 25 diagrams in the text. Pp. vii +164. Paper covers. $\$ 2.00$.

Part II. The Prodromus of Nicolate Steno's Latin Dissertation on a Solid Body Enclosed by Process of Nature wiтhis a SoLid. Translated into English by Professor John G. Winter, University of Michigan, with a Foreword by Professor William H. Hobbs. With 7 plates. Pp. 165-283. Paper covers. $\$ 1.30$.

Part III. Vesuvides in Antiquity. Passages of Ancient Authors, with a Translation and Elucidations. By Francis W. Kelsey. Illustrated.

Vol. XII. Studies in East Christian and Roman Art.

Part I. East Christian Paintings in the Freer Collection. By Professor Charles R. Morey, Princeton University. With 13 plates (10 colored) and 34 illustrations in the text. Pp. xii +87 . Bound in cloth. $\$ 2.50$.

Part II. A Gold Treasure of the Late Roman Period from Egypt. By Professor Walter Dennison, Swarthmore College. (In Press.)

\section{THE MACMILLAN COMPANY}

Publishers

64-66 Fifth Avenue

New York 


\title{
University of Michigan Studies-Continued
}

Vol. XIII. Documents from the Cairo Genizah in the Freer Collection. Text, with Translation and an Introduction by Professor Richard Gottheil, Columbia University. (In Preparation.)

\section{SCIENTIFIC SERIES}

Size, $28 \times 18.5 \mathrm{~cm} . \quad 4^{\circ}$. Bound in cloth

Vol. I. The Circulation and Sleep. By Professor John F. Shepard, University of Michigan. Pp. $x+83$, with an Atlas of 83 plates, bound separately. Text and Atlas, $\$ 2.50$.

Vol. II. Studies on Divergent Series and Summability. By Professor Walter B. Ford, University of Michigan. Pp. xi+193. $\$ 2.50$.

\section{University of Michigan Publications}

HUMANISTIC PAPERS

\author{
Size, $22.7 \times 15.2 \mathrm{~cm} . \quad 8^{\circ}$. Bound in cloth
}

Latin and Greek in American Education, with Symposia on the Value of Humanistic Studies. Edited by Francis W. Kelsey. Pp. $\mathrm{x}+396$. $\$ 1.50$.

\section{CONTENTS}

The Present Position of Latin and Greek, the Value of Latin and Greek as Edecational Instrements, the Nature of Celture Studies.

Symposia on the Valee of Hemanistic, particularly Classical, Stddies as a Preparation for the Study of Medicine, Engineering, Law and Theology.

A Symposicm on the Value of Hemanistic, particularly Classical, Studies as a Trainivg for Men of Affairs.

A Symposidm on the Classics and the New Eddcation.

A Symposium on the Doctrine of Formal Discipline in the Light of Contemporary Paychology.

The Menaechir of Plautus. The Latin Text, with a Translation by Joseph H. Drake, University of Michigan. Pp. xi+130. Paper covers. $\$ 0.60$.

\section{THE MACMILLAN COMPANY}

Publishers 


\section{BY THE SAME AUTHOR}

Modern Thodght and the Crisis in Belief. Cloth, 12mo, \$1.50.

A clear, compact, and reverent statement of precisely what conclusions have been reached in the application of scientific methods of research to the text of the Bible, the history of Biblical times, and the bases of Christian religion.

"A book of marked interest and integrity of thought, which must prove of great service both to the clergy and to the educated general public ... may be commended to thoughtful people generally, but especially to students who have been instructed in the general principles of philosophical idealism, and are wrestling with the problem of reconstructing their religious creed."-The Philosophical Review.

\section{STANDARD PHILOSOPHICAL WORKS}

Democracy and Education. By John Dewey, Ph.D., Professor of Philosophy in Columbia University. 434 pp., 8vo, $\$ 1.50$.

"This book repays the most exhaustive reading. It is the wisest book, the strongest book, of the most fertile thinker of the time in education."-Living Church.

A Brief History of Modern Philosophy. By Dr. Harald Höffding. Translated with author's permission by C. F. Sanders, Professor of Philosophy in Pennsylvania College. 324 pp., 8vo. $\$ 1.50$.

"There is no saner or wiser guide to the study of philosophy now living than Professor Höffding. Particularly valuable are his appreciations of contemporary thinkers, including Boutroux, Bradley, Bergson, and Eucken."-Educational Review.

Mediaeval Jewish Philosophy. By Isaac Husik, Ph.D., Lecturer in Philosophy in the University of Pennsylvania. 432 pp., 8vo, $\$ 3.00$.

An objective and not too critical exposition of Jewish rationalistic thought in the middle ages that will appeal alike to the scholar and the intelligent non-technical reader. The author has interpreted the ideas of the mediaeval thinkers, from their own point of view, as determined by their history and environment and literary sources, religious and philosophical, under the influence of which they came.

\section{THE MACMILLAN COMPANY}


The Philosophy of Nietzsche. By A. Wolf, M.A., D.Litt., Fellow of the University of London. 114 pp., 8vo, $\$ 1.50$.

The substance of a course of three lectures delivered at the University of London whose object was to present the salient ideas of Nietzsche in an impartial and coherent manner, with a minimum of technical terms. This scholarly analysis of his writings will do much to clear up prevailing misconceptions regarding Nietzsche's responsibility for present-day German militarism.

Advertising and its Mental Laws. By Henry Foster Adams, Instructor in Psychology, University of Michigan. 330 pp., $12 \mathrm{mo}, \$ 1.50$.

Intended primarily for a text for students of the psychology of advertising, although many of the facts contained in it will be of value also to advertising men. The author has assumed throughout that the success of any advertisement depends upon the several factors of attention, memory, feeling, and action, and on this basis he discusses such elements as the position on the page, the size of the advertisement, the frequency with which it is repeated, the color used, the size and kind of type, and the size and kind of picture which illustrates it. The laws of volition or action have been treated with especial thoroughness and rules given to increasing the action-producing power of an advertisement.

The Next Step in Democracy. By R. W. Sellars, Ph.D., Assistant Professor of Philosophy in the University of Michigan. 275 pp., $12 \mathrm{mo}, \$ 1.50$.

Chapters on The Spirit of Modern Socialism, Socialism in the Making, What Socialism Hopes to Accomplish, Misconceptions of Socialism, Objections to Socialism, Objections and Tendencies, The Ethics of Labor, The Growth of Justice, Some Principles of Pecuniary Reward, The Conditions of a Social Freedom, Reflections on the War, Can we Universalize Democracy?

"One of the best books written recently on the philosophical aspects of the Socialist movement."-Philadelphia Public Ledger.

Essentials of Psychology. By W. B. Pillsbury, Professor of Psychology, University of Michigan. $362 \mathrm{pp} ., 12 \mathrm{mo}, \$ 1.25$.

"The work is a simple, straightforward presentation of the accepted data of psychology, intended for introductory college classes. Approximately 100 pages are devoted to the physical aspects of mental life, such as the nervous system, behavior and sensation. There are concluding chapters on work, fatigue, sleep, and disturbances of the self." - Journal of Educational Psychology.

\section{THE MACMILLAN COMPANY}

Publishers

64-66 Fifth Avenue

New York 
Fundamentals of Psychology. By W. B. Pillsbury, Professor of Psychology, University of Michigan. 562 pp., 12mo, $\$ 2.00$.

This volume fills the gap existing at the present time between the text-books on psychology and the larger treatises and reference works. The book is intended to be used as a text for students who are devoting a full year to the subject. The treatment, however, assumes no knowledge of the subject on the part of the student, and at the same time it is full enough to give not merely an orderly statement of the results of modern psychology, but also to give the evidence for those conclusions, and to state opposing theories where opinions differ on important questions. In addition to the more directly psychological material, a discussion of the nervous system is included which has been made sufficiently full to make clear the references in the later chapters.

The History of European Philosophy. By Walter P. Marvin, Collegiate Church Professor of Logic and Mental Philosophy in Rutgers College.

The present work, a history of philosophy from the beginning down to modern times, has two distinctive features. It is written from a realistic point of view; and it contains a treatment of the development of the sciences.

The scholarliness and accuracy of the book, and the fact that it keeps close to real, human interests, and treats them in a concrete and interesting way, makes it a valuable textbook or second text for introductory courses in the history of philosophy.

The subject is presented in three separate sections, of which the first is introductory, the second covers the Greek and Roman Periods, and the third deals with modern philosophy. The chapter headings of this third part are as follows: The Atlantic Period, Medieval Thought; The Age of Discovery; The Modern Philosophical Movements; Rationalism and Naturalism; Phenomenalism, Positivism and Idealism; The Doctrine of Evolution; Romanticism; Present Philosophical Tendencies.

\section{THE MACMILLAN COMPANY}
Publishers
64-66 Fifth Avenue
New York 




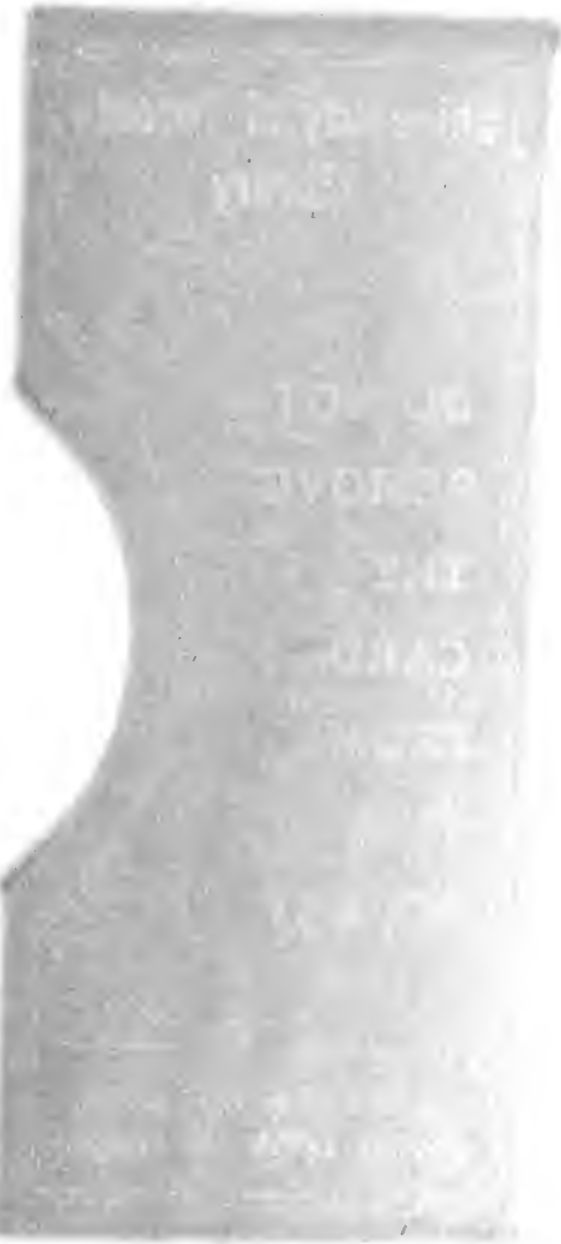




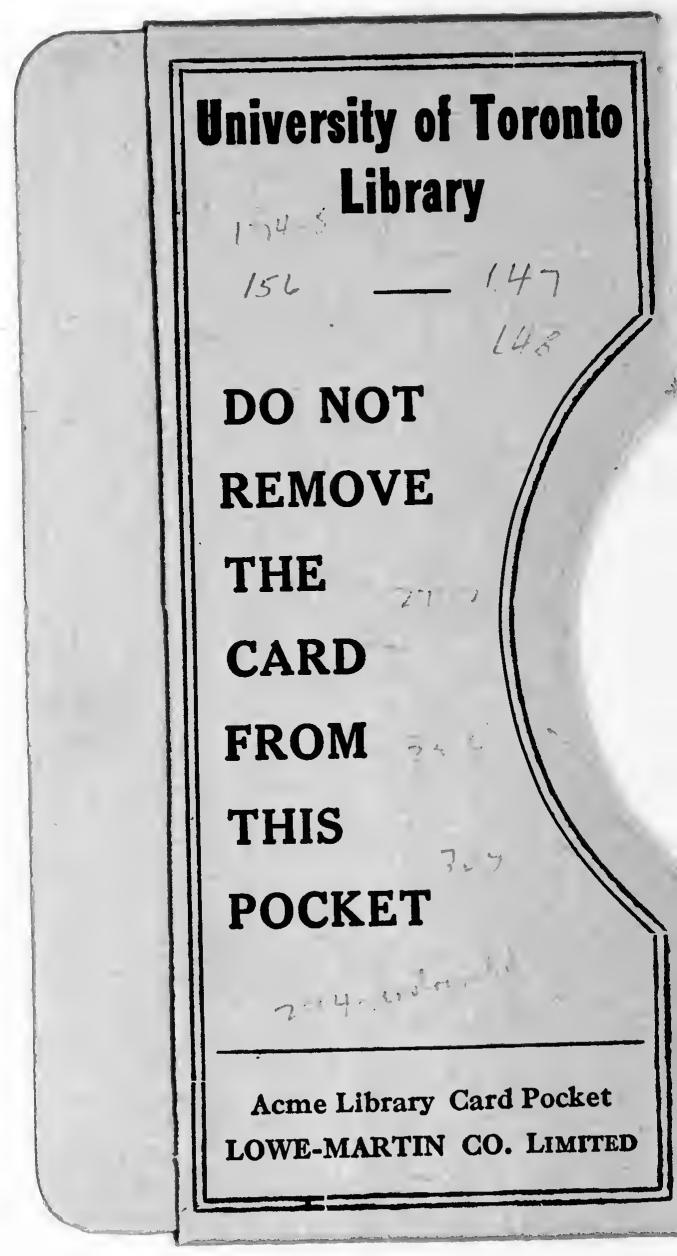


